\title{
The Importance of Being Shawville: The Role of Particularity in Community Resilience
}

\author{
by
}

Lyndal Laurel Neelin

A thesis submitted to the Faculty of Graduate and Postdoctoral Affairs in partial fulfillment of the requirements for the degree of

Doctor of Philosophy

in

Canadian Studies; Political Economy

Carleton University

Ottawa, Ontario

(C) 2012

Lyndal Laurel Neelin 
Library and Archives

Canada

Published Heritage

Branch

395 Wellington Street

Ottawa ON K1A ON4

Canada
Bibliothèque et

Archives Canada

Direction du

Patrimoine de l'édition

395 , rue Wellington

Ottawa ON K1A ON4

Canada
Your file Votre référence

ISBN: $978-0-494-94233-8$

Our file Notre référence

ISBN: $978-0-494-94233-8$
NOTICE:

The author has granted a nonexclusive license allowing Library and Archives Canada to reproduce, publish, archive, preserve, conserve, communicate to the public by telecommunication or on the Internet, loan, distrbute and sell theses worldwide, for commercial or noncommercial purposes, in microform, paper, electronic and/or any other formats.

The author retains copyright ownership and moral rights in this thesis. Neither the thesis nor substantial extracts from it may be printed or otherwise reproduced without the author's permission.
AVIS:

L'auteur a accordé une licence non exclusive permettant à la Bibliothèque et Archives Canada de reproduire, publier, archiver, sauvegarder, conserver, transmettre au public par télécommunication ou par l'Internet, prêter, distribuer et vendre des thèses partout dans le monde, à des fins commerciales ou autres, sur support microforme, papier, électronique et/ou autres formats.

L'auteur conserve la propriété du droit d'auteur et des droits moraux qui protege cette thèse. $\mathrm{Ni}$ la thèse ni des extraits substantiels de celle-ci ne doivent être imprimés ou autrement reproduits sans son autorisation.
In compliance with the Canadian Privacy Act some supporting forms may have been removed from this thesis.

While these forms may be included in the document page count, their removal does not represent any loss of content from the thesis.
Conformément à la loi canadienne sur la protection de la vie privée, quelques formulaires secondaires ont été enlevés de cette thèse.

Bien que ces formulaires aient inclus dans la pagination, il n'y aura aucun contenu manquant. 


\section{Abstract}

This work examines the factors that motivate and support community resilience, understood as a community's ability to absorb disturbance without changing state. It looks specifically at the case of Shawville, Québec, a community whose tenacity against a backdrop of socioeconomic and political change in recent decades makes its persistence stand out. Shawville's particular geography, political economy and socio-linguistic identity are interrogated as potential 'footing' for the community's resilience. This investigation shows that together these factors support Shawville in producing and projecting particularity, understood as the community's self-identification as distinct and meaningful. Particularity is required for community resilience.

The scaffolding that supports Shawville's particularity and allows for its resilience is linked to the insights of resilience theory through the use of two resilience theory models. The fruitful use of analytic tools borrowed from environmental science demonstrates that resilient systems, be they ecological or social systems, require similar conditions. Resilience requires variability (internal flexibility) and diversity (external variety). In social systems variability and diversity are especially important to the realm of meaning-making. A community's capacity for resilience is only as robust as its capacity to make meaningful its current situation, its past experiences and its potential futures. Access to a wide range of alternative interpretations and responses both enriches a community's capacity for meaning-making and enhances its particularity.

The research is interdisciplinary, drawing on concepts and literatures from a variety of academic fields including anthropology, rural geography, history, and political economy. The data was collected through semi-formal interviews, observation and the local weekly newspaper. 


\section{Acknowledgements}

I would like to thank the many people who helped me to complete this ambitious project. First and foremost, I owe much gratitude to the people of Shawville who generously shared their stories, time, and thoughts with me. Their enthusiasm for the work I was doing meant a great deal to me. Special thanks to Mayor Armstrong and the Shawville Town Council for their warm welcome to me as an observer at their meetings, to Heather Dickson who generously provided me with space on the pages of The Equity and room in her own office where I could access archived copies of the paper, to Elsie Sparrow, Pearl McCleary and Venetia Crawford who introduced me to the Shawville Archives and its volunteers, and to Margaret Hodgins and the Shawville Women's Institute whose confidence in my success was heartwarming.

I am grateful to Dr. Anne Trépanier for permission to make use of her 'refondation' model in my work, and for her willingness to discuss the ideas I was working to convey. My thanks to Dr. Mark Skinner for several valuable conversations and a helpful reading list. Special thanks to my co-supervisors Drs. Donna Patrick and Pauline Rankin who patiently stayed with me through the process of dissertation writing. All four members of my dissertation committee have been an invaluable help. Thank you.

I want to acknowledge with gratitude the financial support I received from Carleton University's School of Canadian Studies and the Faculty of Graduate Studies as well as the government of Québec's Fonds de recherche du Québec - Société et culture.

My friend and neighbour Lynda Wegner warrants special thanks for her help with formatting, maps and figures. Under her capable ministrations, this work took shape in its current polished form. 
I want to thank my daughters for being so willing to chat about the university 'scene', to hear about my progress and to help with interview transcriptions and proof reading. That I owe my husband, Michael, many thanks for the maps and figures in this work, and for his overwhelming support, goes without saying. I owe thanks as well to the confidence and encouragement of my wide extended family. Thank you all. 


\section{Dedication}

I would like to dedicate this work to

Janice and Howard Briggs

whose presence in my story

is part of the solid ground beneath my feet. 


\section{Table of Contents}

\section{Chapter One: Introduction}

The Research Problem...................................................... 1

Situating the Research Project.......................................... 8

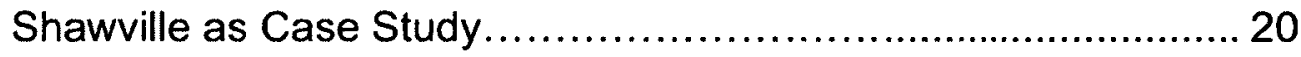

Overview of the Work's Format........................................... 24

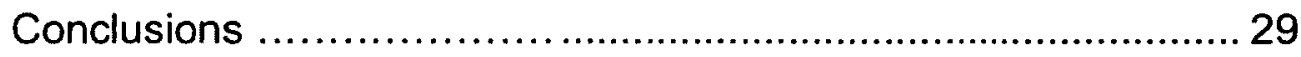

\section{Chapter Two: On Method and Methodology}

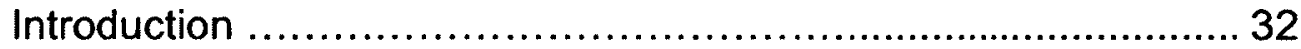

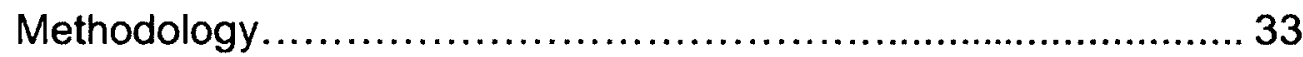

Getting the Questions Right ...................................... 38

Research Method .................................................... 42

Doing Research in Your Own 'Back Yard'............................... 58

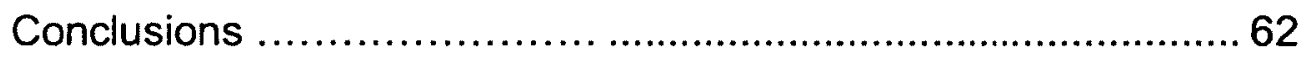

\section{Chapter Three: Geography - Place, Space and Location}

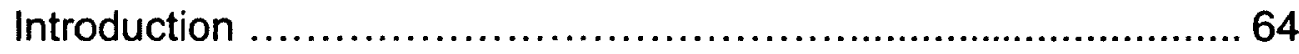

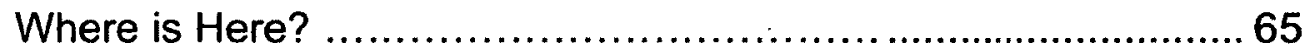

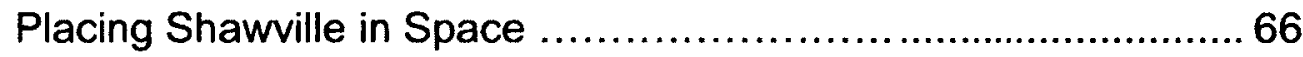

Home Space ............................................................ 71

Contested Space .................................................. 74

Distinct Space .................................................... 81

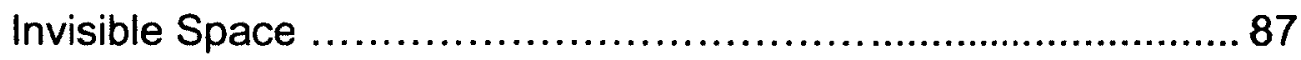

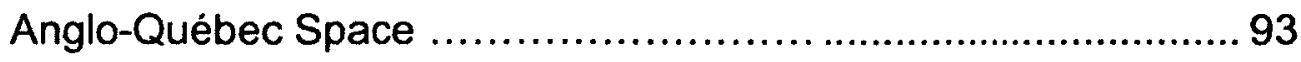


"Ottawa Valley" Space ................................................... 95

Meaningful Space .................................................... 100

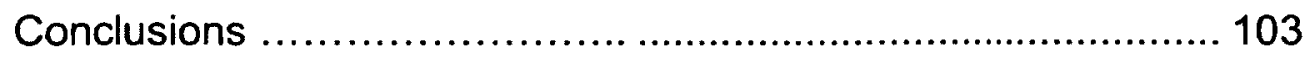

\section{Chapter Four: Political Economy - River, Rails and Relationships}

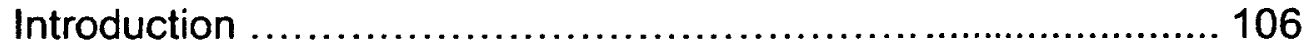

Shawville's Political Economy: Some Context ...................... 108

The Particular 'Good' of Useful Skills .................................111

The Particular Value of Family Farms .................................119

The Particular Value of Relative Isolation ............................. 132

Rails \& Relationships ........................................... 139

The Particular Value of Going Slowly ................................ 143

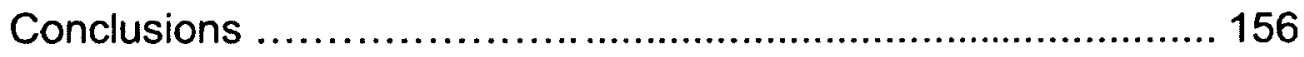

\section{Chapter Five: Identity - Interconnection, Continuity and Story}

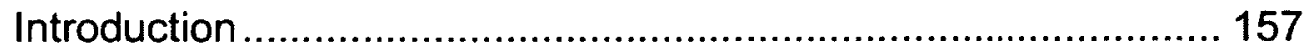

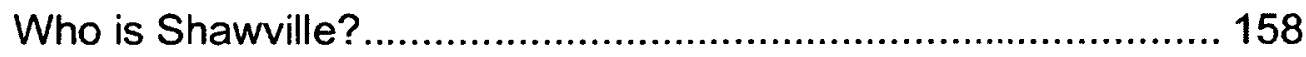

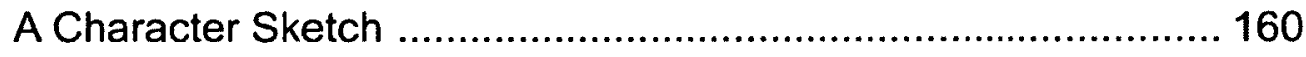

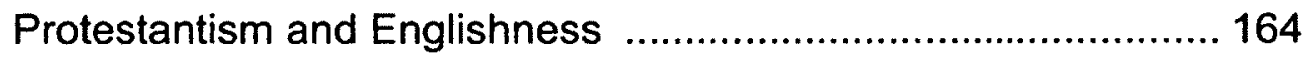

Not Such a Long Way from Tipperary ...................................... 168

"Fiddle and Twang" in the Valley .............................................. 175

Connections and Continuity ................................................... 182

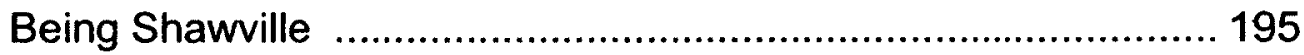

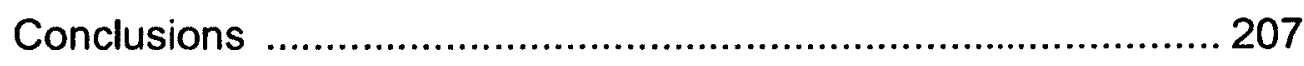




\section{Chapter Six: Conclusions and Questions}

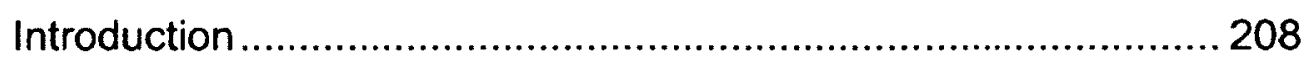

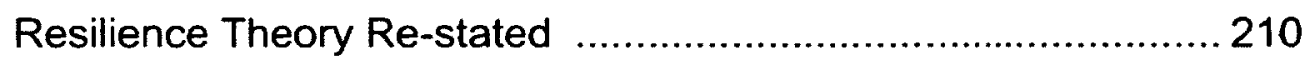

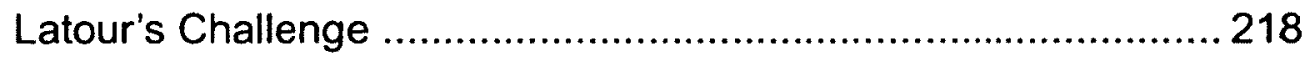

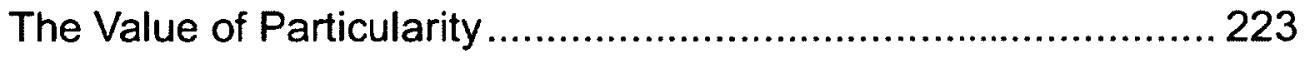

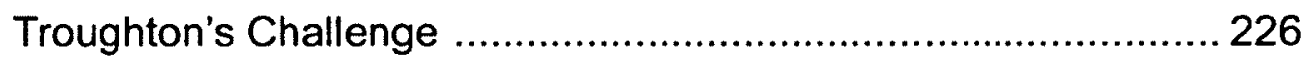

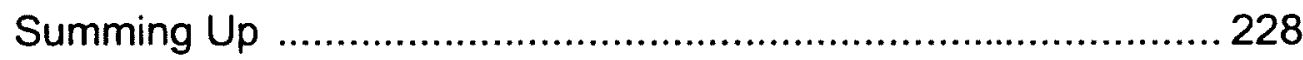

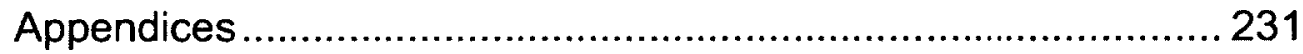

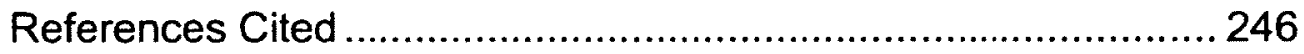




\section{Table of Maps and Figures}

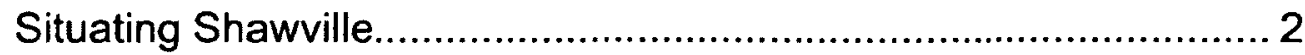

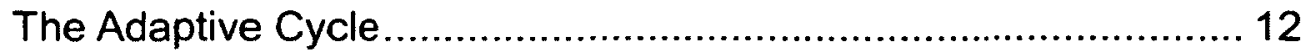

Adaptive Cycles Interacting at Multiple Scales ............................. 15

Equilibrium as one "Basin" among many ................................... 17

Conceptualizing Shawville ............................................ 34

Shawville under the Collide-o-Scope Lens............................ 37

Timeline of Significant Events in Québec History .................... 53

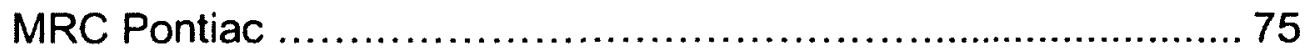

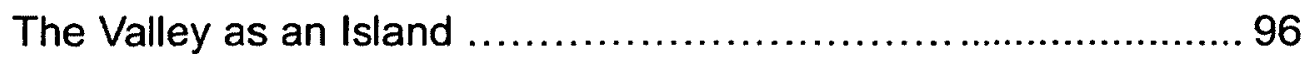

Resilience Basin Delimited by Refoundation's Poles ................ 101

Mobility: Railroads, Highways and the River.................... 140

Population and Age Structure in Shawville, Québec 1996-2006 .. 150 


\section{The Importance of Being Shawville: The Role of Particularity in Community Resilience}

\section{Chapter One: Introduction}

It was about, oh goodness, could be twenty years ago time goes so fast, on Main Street, Shawville there was these metal poles put up and on each pole was a sign to tell us which hours of the day we could park and for how long and I don't know who but I will say the-lads-around-Shawville, ripped them out. We weren't going to be told how we could park along the roads of the town of Shawville.

(Pearl McCleary Fall 2010)

\section{The Research Problem}

My interest in the town of Shawville, ${ }^{1}$ Québec was piqued soon after I moved to the area with my family in 1991 . I was struck by the community's determined survival as a distinct place and identity against political and economic odds. Shawville is situated in the Regional County Municipality of Pontiac (Pontiac MRC), wedged between the Ottawa River and the Gatineau Hills. The town is very close to the Ontario-Québec provincial border. It is seventy kilometres northwest of Ottawa-Gatineau, Canada’s National Capital Region. ${ }^{2}$

Shawville is among the last English-speaking majority communities in Canada's francophonemajority province of Québec. Its location in Québec, and the concomitant political and economic pressure to speak French as the "shared public language" of Québec (Oakes and

1 The 'Shawville' represented in this text is based on the particular instance of the community articulated by and experienced within the scope of my interviews and investigation. This Shawville is only loosely captured in the physical town site and refers more particularly to a group of people who share a history, a language and a worldview, and identify themselves with Shawville.

2 See map on page 2. 


\section{Situating Shawville}

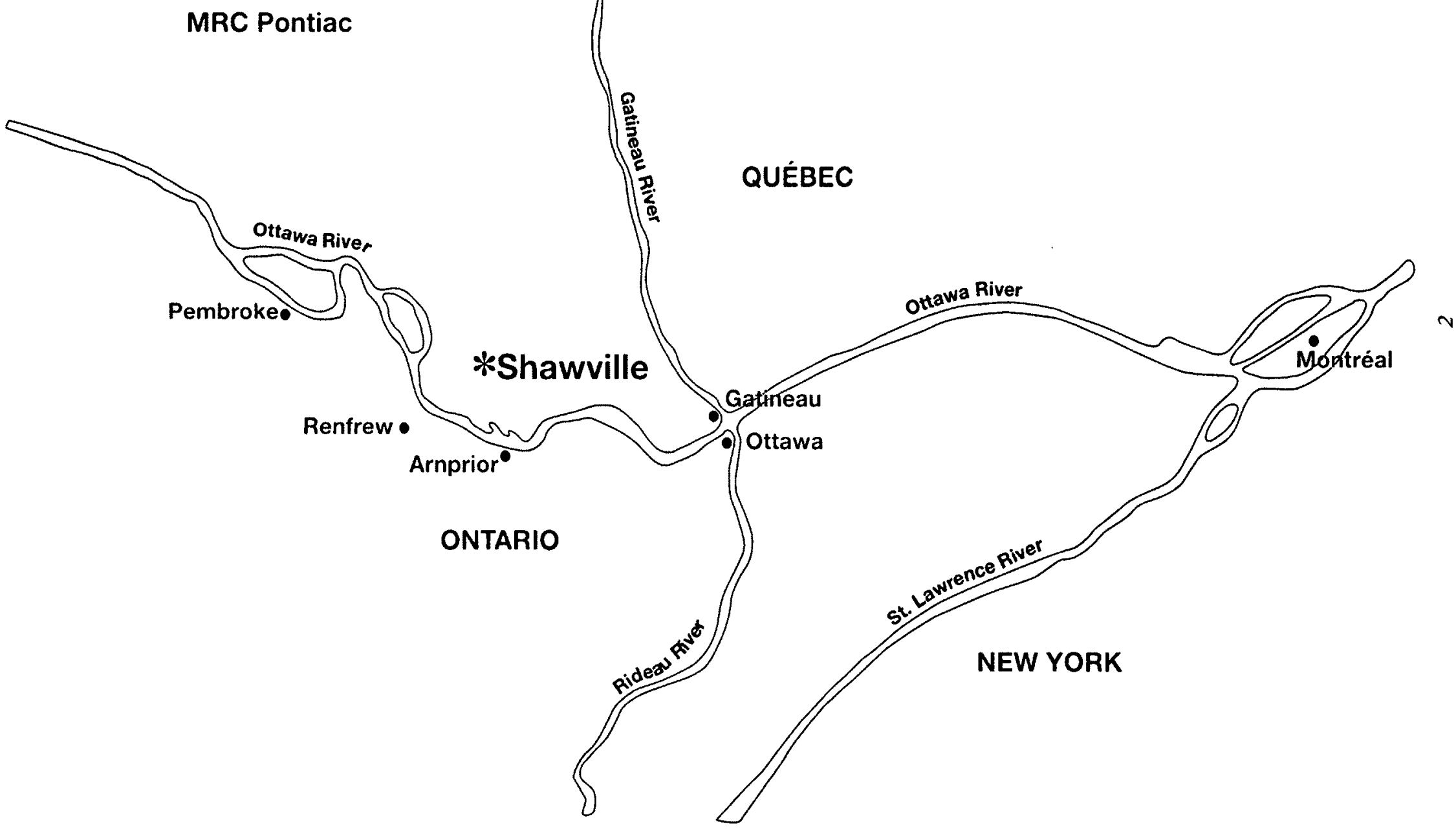


Warren 2007:84), made its enduring 'Englishness' ${ }^{3}$ conspicuous and therefore intriguing. Englishness seemed to be a defining characteristic of the community, as significant to its selfidentification as the area's rolling fields and pine forests. While it was Shawville's Englishness that first caught my attention, the present work is emphatically not an exploration of linguistic tension in Québec, nor is it another study of Canada's bilingual mythos. Shawville's Englishness is significant to this work as evidence of the community's ability to remain 'itself' through a period of socio-linguistic and political upheaval. ${ }^{4}$ It was Shawville's deliberately distinctive identity as "the English village"5 in West Québec that first led me to ask, "What sustains this community?" How is it able to accommodate change without becoming a changed place? What makes Shawville resilient?

Religious affiliations and profound Christian faith are also defining features of Shawville's collective identify. Despite, or better expressed, in deference to, its centrality in the life of this community I have not made religion a specific focus of this work. Like linguistic tensions and Québec nationalism Shawville's character as 'religious' should be understood as a pervasive and salient feature of the community's experienced reality.

3 The term Englishness as I use it here draws on Meinhof and Galasiński's work (2005). They discuss the idea of identity, especially collective identity, as a verb: a way of being that encompasses language, behaviours and shared stories (2005). Meinhof and Galasiński's concern is with the 'vocabulary' describing Germanness or Polishness. Shawville's Englishness is something we will consider more specifically in the discussion of identity in Chapter Five.

4 Québec has seen several decades of socio-political change beginning with the Quiet Revolution of the 1960s (see Québec history time-line on page 53). Salient to Shawville's context are the rise of Québécois nationalism, the election of the separatist Parti Québécois, language laws restricting the use of English in the public sphere and access to English-language schooling, referenda re Québec's secession from Canada in 1980 and 1995, on-going impacts of a Francophone government and restrictions on the use of English. I do not want this work to be side-tracked into a discussion of linguistic/governance questions. Shawville's location in Québec is obviously pertinent. I will return to its specific significance in supporting Shawville's resilience at some length in larer discussions.

5 Debra Srevens Spring 2010. 
Shawville has 1,664 residents at the time of this writing. ${ }^{6}$ Statistics Canada's 2006

Community Profile ${ }^{7}$ describes the village as predominantly English-speaking (eighty-five percent report speaking English "most often at home"), remarkably homogeneous (the census reports a total 'visible minority' population of ten), and unusually sedentary (two thirds of Shawville's residents have roots in the area that go back three or more generations). This last characteristic is significant given the well-documented predisposition of English-speaking Quebeckers to move on to greener pastures, especially since the rise of the Québec separatist movement in the mid-1960s (Rudin 1985). My interviewees in Shawville described their community as "tight" (close knit, closed and quick to close ranks), a sort of enclave, a place with a long memory and deep family ties. ${ }^{8}$

The numbers in Statistics Canada's 2006 Community Profile reflect Shawville's aging population, the 'dip' in the number of people between twenty and fifty years of age that is characteristic of English Québec (reflecting the high percentage of that demographic who leave the province to study and work), and the small number of people employed in "occupations unique to primary industry" (30 of the 585 people with work) despite the area's long-time identification with agriculture and forestry (Statistics Canada 2006). What the statistics cannot reveal is what holds this community together on this tenuous bit of ground. They cannot account for Shawville's continuity and tenacity over time. How is it that this community endures? What supports it? How has it navigated the social, political and economic turbulence of recent decades? How has it maintained its sense of self and kept its balance? These questions led me to the current interrogation of the factors supporting Shawville's resilience.

6 Only 2011 population data became available from StatsCanada in February 2012.

7 Data for 2011 re 'families and households' and 'language' was not yet available at the time of writing.

8 Cited from interview data collected in the spring and summer of 2010. 
In Shawville, I observed community meetings and events, conducted semi-structured interviews, did research at the local archives, and wrote a series of articles for the local weekly newspaper. My goal in these activities was to examine what it meant to 'be' Shawville, and discover the source or sources of the community's on-going strength and stability. The specific case of community resilience I studied in Shawville drew on an amalgam of sociohistorical, geographic, and political economic factors to create a sense of distinction and uniqueness. The community's self-identification incorporates time, place, and experience. My findings demonstrate that Shawville experiences, reproduces and projects particularity (a distinct sense of people and place) with sufficient conviction to both motivate and enable the community's resilience.

Based on my research findings, this dissertation argues that Shawville's resilience relies on its particularity. It is ultimately Shawville's experience of and belief in its own distinctness and significance that give it both the will and the ability to keep its balance on the shifting ground of socio-political and economic change. Particularity is both an experience and a perception; it is manifest in the unique intersections of "places, people, property, pasts, politics, and power" (Halseth 1998:226) that constitute a 'particular' place/community that is distinctive and identifiable as and for itself.

The production of particularity is a long-standing concern of human communities. Indeed, Arjun Appadurai contends that the entire ethnographic record can be read as witness to the many and varied ways in which people work to produce and maintain the sense of belonging, continuity and place that constitutes particularity (1996:179). We inscribe particularity onto ourselves through various practices from the names we give our children to the ritual scarring of our bodies (circumcision, tattoos and piercings). We inscribe it into the earth in footpaths, structures, cemeteries and highways (Appadurai 1996:179-180). Because particularity is 
ephemeral, its production and reproduction always involve continuous, deliberate effort. Now, in the context of "deterritorialized, diasporic and transnational" modernity, writes Appadurai, the reproduction of particularity "is increasingly a struggle" (1996:188-9). Shawville's relatively long-standing (within Canada's own brief history) and continuing success in the work of reproducing particularity makes it an interesting community to study.

The zeitgeist of our age (light and speed incarnate in micro-technologies and instant communication) has been called 'mobility' (Thrift in Cloke 1994:216). It can be seen in the explosive growth of our ability to be mobile, and the parallel growth in the expectation that we will be constantly "on the move". Mobility thins out our experiences of history, place and community. Thomas Friedman (2005) celebrates the deliberate "flattening" of the particularities that distinguish one place from another. He calls these distinctive places "sites of friction" and describes them as obstacles to the fluid circulation of goods, ideas and money on an otherwise frictionless plane. Others argue that we need friction in order to gain traction for both thought and activity. Christina Muehlberger for example, claims that "a 'place' is vital in order to ground agency" and that "a placeless space [one without a particular place or community] actively atomizes people" actually dissipating agency. There are, of course, many who would argue the contrary, who see the 'gift' of the cybersphere as an example of 'space' without place drawing strangers together and equipping them with previously unimaginable agency. Michael Hardt and Antonio Negri (2000) foretell a world free of the "divisive thrall" of the particular, with fewer and fewer distinctions, no boundaries, no binaries, no outside, and no places 'between' (2000:190). In the world of "Empire" (referring to the title of their book), the particular has been superseded, for good or ill.

9 Muehlberger, Christina. Conference Paper Presentation. Carleton University Nov. 7, 2011. 
Yet people, it seems, have always been ready to do the work involved in producing and reproducing particular place/communities. The effort responds to an imperative, consciously or unconsciously experienced. One of Friedman's interviewees warns that the loss of such places will have serious consequences since they are the tools we use to locate ourselves in the world. It is these "distinctive places and communities that give us our bearings" (Friedman 2005:236). They provide for a valuable grounding threatened by Friedman's vision of a "flat world" without distinguishing features. Appadurai claims that marked and particular places/ communities serve as "multiplex interpretive site[s]". They "provide the frame or setting within which various kinds of human action (productive, reproductive, interpretive, and performative) can be initiated and conducted meaningfully" (Appadurai 1996:184).

We will return to the significance of "meaning-making" (and homo narrans' 10 compelling need to make sense of the world) at some length below. Here, it is enough to flag the connection between particularity and the construction of meaning. The role particularity plays as both the context for and the content of "meaning-making" (i.e. homo narrans' capacity to make sense of the world by constructing meaning), is a significant part of what makes it vital to a community's resilience. Resilience, understood as a community's ability to keep its balance on shifting ground, relies on its capacity to accommodate change within a meaningful narrative. Meaning is a requirement for resilience. Particularity is required for meaning-making.

10 I have found the phrase homo narrans used (unattributed) across disciplines (see for example Mechling 1991). I have tried to track its original use without success. In the first chapter of his book titled Homo Narrans John Niles provides a description of what the phrase incorporates: "Through storytelling, an otherwise unexceptional biological species has become a much more interesting thing, Homo narrans: that hominid who not only succeeded in negotiaring the world of nature, finding enough food and shelter to survive, but also has learned to inhabit mental worlds that pertain to times that are not present and places that are the stuff of dreams" (1999:3). 


\section{Situating the Research Project}

This investigation examines a part of Québec which is often overlooked in the literatures of history, political economy, and sociology in Canada. Scholarly writing about the experience of Anglophones in Québec is, by and large, limited to the urban world of Montréal (Rudin 1986; Handler 1988; Scowen 1991; and Oakes and Warren 2007). The literatures of rural studies and rural sociology also tend to overlook West Québec (some would argue they omit Québec in toto)" as a subject of study (Parson's 1977 study of Gatineau Township is an exception). Histories of the region are sparse. Those written in English tend to stop short in Aylmer/Gatineau, or focus on the Ontario side of the Ottawa River. Similar histories by French writers also tend to skip past Pontiac MRC. Works about Shawville that do exist are local and parochial, or historical, so that this contemporary study represents an important new contribution. ${ }^{12}$ My study expands the presence of this particular small corner of rural Canada within our collective body of knowledge.

The particular community of Shawville, like many small communities across rural Canada more generally, faces enormous socio-political and economic odds (Markey et al. 2008; Stedman et al. 2004; MacKenzie 1992; and Leckie 1989 inter alia). In the context of a shrinking rural population and a shift away from agriculture as a vital economic driver in Canada, rural geographers debate the future usefulness of "rural" as an analytic category (Troughton 1995; Halseth 1998), and the changing meanings of "rurality" (Besser 2009; Reimer 2006; Little 1999; Liepins 1999). Current economic doctrine advocates integration, concentration and centralization (i.e. the de-valuing of particularity). Farming communities

11 To wit the not infrequent publication of studies of Canada that exclude Québec (for example see Laker, Jason 2011, and Mookerjea, Sourayan, Imre Szeman, and Gail Faurschou (eds.) 2009).

12 Caldwell 1980; Gaffield 1997; and Stevenson 1999 are examples of works about Anglo-Québec with an urban focus. 
and the small towns they support and are supported by feel under siege (Adams 2002; Pawlick 2009). The disparate and particular communities of rural Canada are under pressure to fit themselves into the "golden straightjacket" (Friedman 1999) of market expectations. The requisite alterations already underway in the form of amalgamations and increasingly centralized regulation promise to be uncomfortable at best. ${ }^{13}$ They also threaten to disrupt local particularity and thus jeopardise community resilience, putting at risk the particular, orienting place/communities of small town Canada.

This project responds to Michael Troughton's 1995 challenge to the Canadian Association of Geographers. Addressing that organization as its past president, Troughton called for "ongoing and critical evaluation of former and current operational structures" (i.e. past and present policy and practice re rural Canada) and "a search for models which might better realize the system potential and halt its decline (i.e. value and support rural places/ communities)" (Troughton 1995:300). In this work, I identify the factors that sustain Shawville as Shawville, and point to "current operational structures" that threaten to undermine those supports. In doing so, I call attention to the scaffolding that currently supports the community's resilience, a "model" already working to safeguard Shawville's potential and mitigate (for the time being) its decline.

Much of what I learned about Shawville's resilience speaks to the situation of rural, agricultural communities in Canada more generally. Along with circumstances unique to its own context, Shawville faces the generalized and much documented challenges of chronic unemployment, falling farm incomes, and a declining and aging population that will lead with time to fewer and fewer local resources, less discretionary income, a smaller tax base,

13 The Mayors of Shawville and the surrounding rural municipality of Clarendon described feeling enormous pressure to amalgamate, both with each other, and with other neighbouring communities. Mayor Armstrong, in particular, grieved that the increasing costs of conforming to centralized regulations would eventually force amalgamations. Drawn from interview data collected in the spring of 2010. 
and fewer community volunteers (Rudin 1985:289; Halseth 1998:113). I have no doubt that the factors that prove to be supporting Shawville in its particular context are also at work in similar rural/agricultural contexts across Canada.

This work also forges an innovative link between the insights of resilience theory and social science research. Coupling social science with ideas drawn from environmental studies and ecology responds to the pressing need for theories that go beyond the society/nature divide and insist on ways of thinking that acknowledge their interconnection (Latour 2007:5). My project thus adopts two models from resilience theory in the field of ecology through which to examine and explain Shawville's resilience. The models help me to conceptualize the community as a 'system'. This novel dialogue, as well as acknowledging the place of people within the biosphere (rather than as foreign to it), also provides social/human studies with new tools to measure and define change and equilibrium. Most significantly, resilience theory provides models that illustrate the invaluable role of diversity and redundancy in resilience, calling into question the 'naturalized' acceptance of uniformity and efficiency as 'goods' within the constructs of the global economy. The model I used to theorize my findings highlighted the value and significance of particularity to resilience.

The models of adaptive cycles and resilience, together with the ecological theory upon which they draw, offer my work two specific assets. The first is that they separate the word 'change' from the implied subtext of 'progress', allowing change to be examined as a form of 'disturbance' to a community/system without assumptions of forward movement, inevitability or desirability colouring the analysis. Persistence is not assumed to be its opposite. In fact, Carl Folke claims that in ecology the concept of resilience "emerged to address how change and persistence work together" (2009:1). The second offering is that the models provide the word 'resilience' with a useful and productive definition (Holling 
1973; Gunderson 2000; Gunderson and Holling 2002). Resilience theory defines resilience as the capacity of a system to absorb disturbance without changing its state. I have adapted the wording to describe a community's resilience as its ability to absorb change without becoming a different kind of community. Referring to Shawville specifically, I use the definition to describe the community's resilience as its demonstrated ability to appropriate change and continue the performance of being Shawville against a shifting background.

Resilience is not a static endurance in place. It is more like a skater's footwork, a dance of balance and motion that stays on its feet. Both the models I use in my analysis allow for movement. The "adaptive cycle" Holling posits, interrupts any notion of teleologically driven change by insisting instead on a recursive round of growth, consolidation, disturbance and renewal (see figure on page 12). Adaptation is continuous and dynamic but it does not have an obvious end goal beyond beginning again, beyond, as Holling says, "staying in the game" (1973:18). Resilience is modelled as a wide, shallow basin. The basin represents a "zone of attraction" around a centripetal core. A resilient system is able to make adjustments that allow it to remain within its current basin (its existing state of mobile equilibrium). If the system proves un-resilient (the disturbance it experiences is too much to absorb) it "flips states" by passing over the brim of the basin into a new "zone of attraction" centred in a new centripetal core (Holling 1973; Gunderson 2000; Gunderson and Holling 2002). ${ }^{14}$

Resilience is not a question of stasis. As I will insist throughout this work resilience is not measured in the ability to hold firm, or to return to a prior stable state, but in a system's ability to absorb and/or accommodate change such that it remains within its current equilibrium basin (retains its form and function or maintains its identity). It is vital to keep

14 For example, Shawville, given the sources of disturbance it currently faces, might find its new equilibrium as a single-industry town centred in a foreign-owned plant and potentially overwhelmed by imported, temporary labour. Alternatively Shawville might become a 'bedroom' community, home to the urbancentred francophone families who predominate in the expanding western suburbs of Gatineau. 


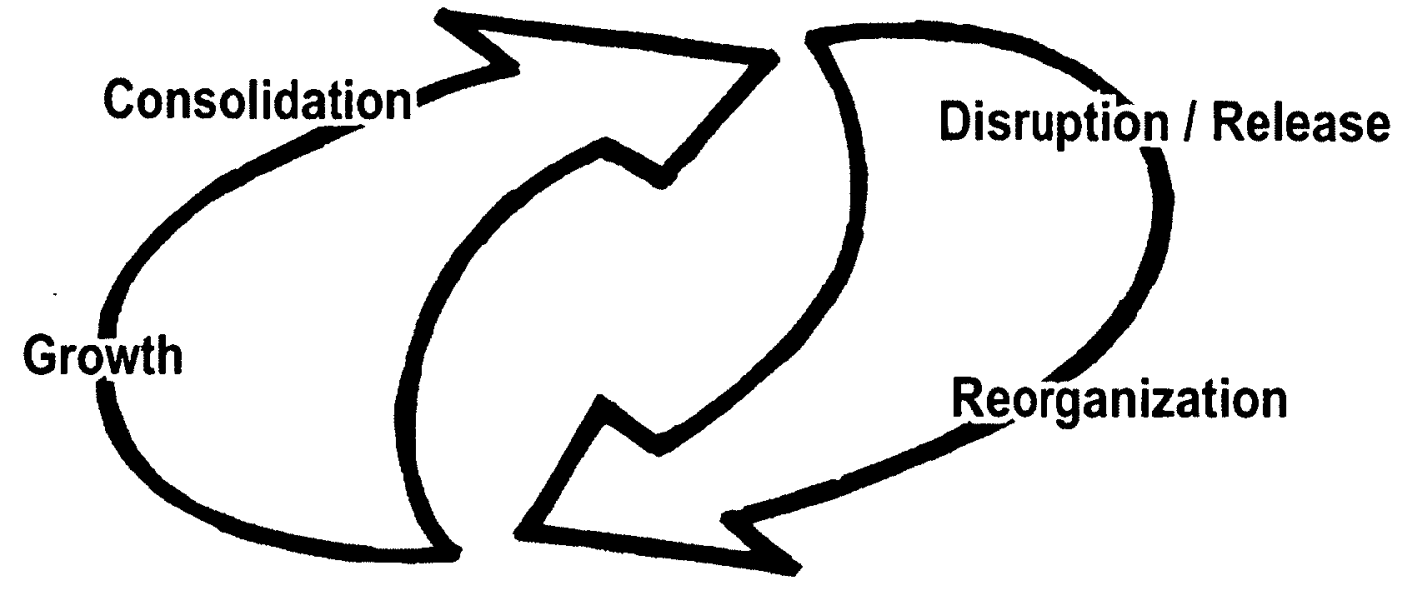

The Adaptive Cycle 
in mind that form, function, identity and even equilibrium are themselves fluid and contingent. Resilience thinking is about working with change. It involves the capacity for transformative reform when appropriate (Walker and Salt 2006:62), and the recognition that there are both openings for daring change and times of fragility within the ongoing and overlapping cycles of growth, consolidation, disturbance and renewal (Walker and Salt 2006:75).

When Lance Gunderson and C.S. Holling observe that "[r]esilience can be the enemy of adaptive change" (2002:30), or Brian Walker and David Salt concede that "in and of itself [resilience is] not necessarily desirable" (2006:27), they are acknowledging that our very capacity for resilience has the potential to cost us the will and ability to reach for transformative change when we must. Their use of the word 'resilience' is unfortunate and potentially confusing (the meaning in this context is subtly different). Their point, however, is important. Their observation relates to a sort of false resilience, an ability to mask the need for adaptive change and perpetuate the status quo, or accommodate change too easily, such that the effects of maladaptive change are masked instead. Thomas Homer-Dixon (2001) believes that our very capacity for adaptation works against us. We get used to things too fast, and forget how they used to be too quickly (2001:394), a characteristic which leaves us vulnerable to working with change even when it works against us. Our capacity to make meaning allows us "to create structures of signification" that become a "virtual reality" vital to our well-being. They can also be detrimental in that "as long as the structures of signification stay in place, the whole system will not transform radically, but rather will return to a previous equilibrium" (Holling and Gunderson 2002:108).

The load-bearing significance of our own constructs are often more difficult to dismantle than real constraints are to ignore. ${ }^{15}$ Eric Hobsbawn (1983) offers an example that illustrates

15 To wit the ready compliance with austerity dictums responding to market exigencies vs. the decades of activism asking for a response to environmental degradation that have gone unheeded. 
the point. He observes that hard hats are worn for practical reasons both for horseback riding, and by soldiers. Soldiers' protective helmets change to reflect innovation in safety design while wearing "a particular kind of hard hat in combination with hunting pink" complies with an "entirely different kind of sense" which has less to do with safety than with self-narrative (Hobsbawn and Ranger 1983:3-4).

Bruno Latour (2010) makes an eloquent plea for the dismantling of two social constructs (narratives) that currently hold sway, dangerously skewing our adaptive capacity:

Along with the narrative of our emancipation from our earthly home [the narrative of modernity and technological progress] we must also shake ourselves loose from the idea of a flow of time moving inevitably and irreversibly forward that can be predicted by clear-sighted thinkers. The spirit of the age, if there is such a Zeitgeist, is rather that everything that had been taken for granted in the modernist grand narrative of progress is fully reversible... [m]aking explicit (that is, manifest) a subtle but radical transformation in the definition of what it means to progress, that is, to process forward and meet new prospects. Not as a war cry for an avant-garde to move even further and faster ahead, but rather as a warning, a call to attention, so as to stop going further in the same way as before toward the future.

(Latour 2010:473)

By borrowing vocabulary and assumptions from ecology to describe a social system I seek to "endogenize" (Pritchard et al. 1998) human beings within the natural world and the exigencies of its recursive and cyclical change.

As introduced above, Holling's model of the adaptive cycle disentangles the whole concept of change from its conflation with progress. He reconceptualises the inevitable march forward as a recursive round of growth, consolidation, disturbance and renewal (Holling 1973, Gunderson and Holling 2002). The interactions of faster and slower cycles at macro and micro scales means that adaptive change has no one form, no universal speed, no direction (see figure on page 15). 


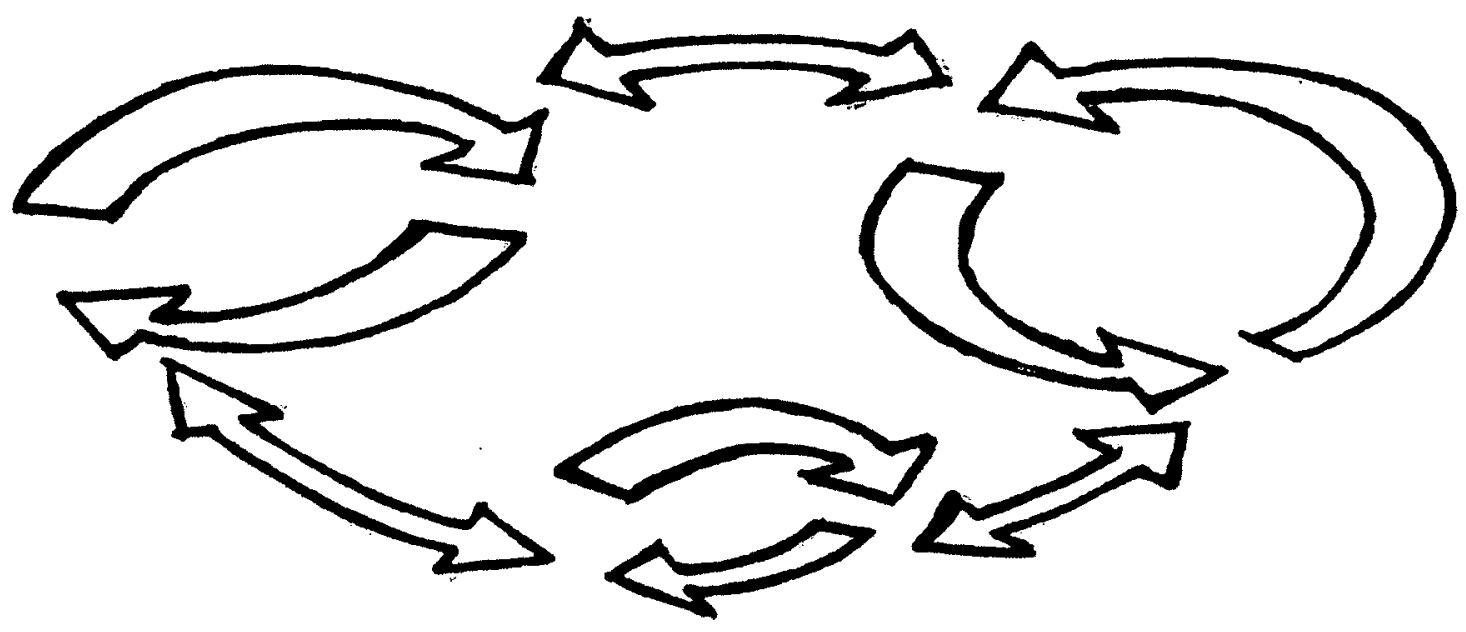

Adaptive Cycles Interacting at Multiple Scales 
Change is not driven by some teleological end. It has no goal to achieve.

Holling broke with both the notion of change as forward movement and of equilibrium as stasis. His model separated change from movement but pushed equilibrium into motion. He conceptualized resilience as a wide, shallow basin. The basin represents a 'zone of attraction', a centripetal force within which a system makes adjustments and shifts its weight in order to maintain its balance (equilibrium). Each basin is one of many possible basins, one experience of equilibrium among many potential alternatives (see figure on page 17). Resilience can be understood as the system's ability to remain within its original basin. It is defined within resilience theory as the amount of disturbance a system can absorb before it "flips states" or jumps into an adjoining basin, and becomes a new kind of system around a new kind of equilibrium (Gunderson 2000:427-8).

Adapted to the study of a human community, resilience, thus defined, can be construed as the community's ability to absorb change without becoming a different kind of community. Resilience by this definition is not the time it takes a system to 'recover' and return to a prior state (what Gunderson and Holling call "engineering resilience" 2002:27), but its overall capacity to accommodate, assimilate, or appropriate change in such a way that the system, the community, retains its original 'being', remains intelligible to itself ("ecosystem resilience" 2002:28). Resilience is not a matter of static endurance, but a dance of balance in motion. 'Being' Shawville is a performance that endlessly incorporates shifting backdrops and changing personalities.

The final insight Holling's work contributes to this study is that interaction between systems at different scales makes change unpredictable and episodic; accidents of timing align events at the micro and macro scale to make sometime disturbances catastrophic and would-be 


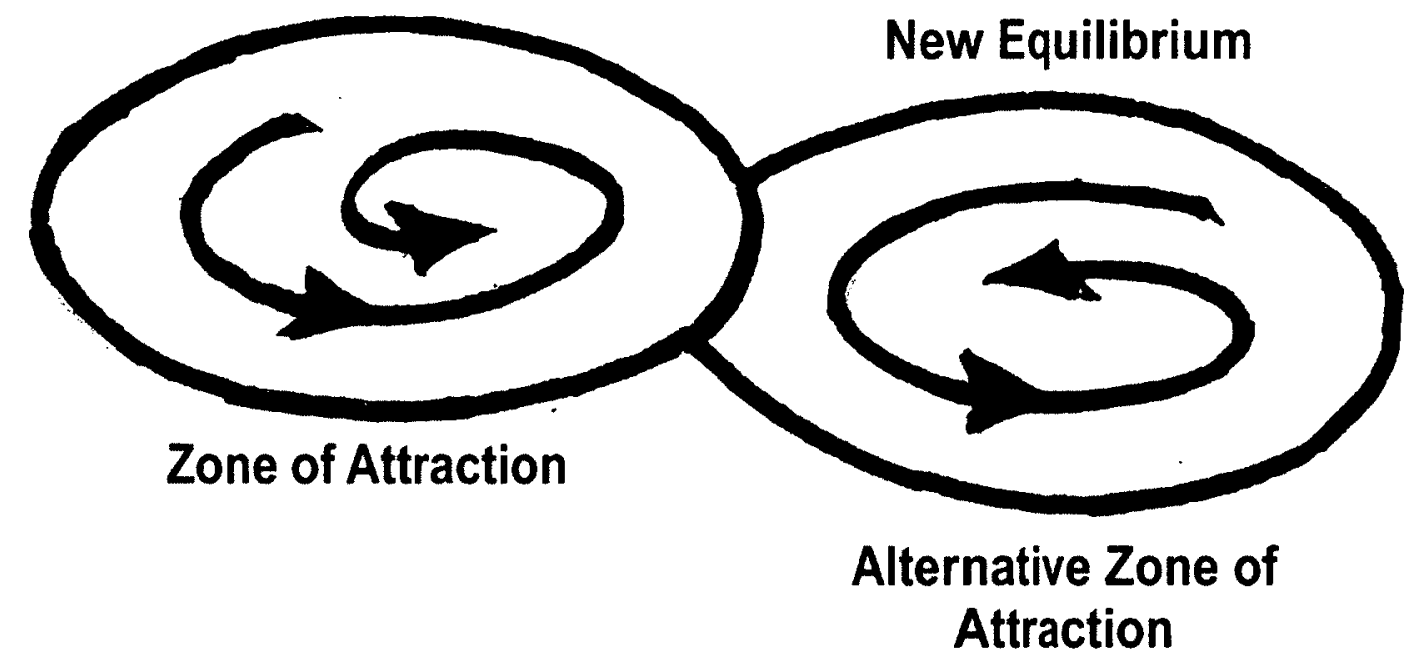

Equilibrium as one "Basin" among many 
catastrophes sometimes manageable. It becomes imperative to look beyond the bounds of any given 'system' to make sense of its cycles and (re)actions. In order to accomplish this, Shawville can be conceptualized through a "collide-o-scope" lens ${ }^{16}$ that holds near and far, past and present in tension and in motion. It is the mobility of the collide-o-scope lens, its capacity to show movement through time, which makes it a useful analytic tool in this work.

Shawville has weathered multiple adaptive cycles without being pushed from one state of being to another. As the pages that follow illustrate, the community has a strong central core with significant centripetal force. There is a clear (though unarticulated) line identifying what is inside and what lies outside its "zone of attraction". A broad self-identification provides for a wide basin with room for movement and the shifting of weight as needed. Shawville's "basin" also has a well-seated, deep foundation. The particularity of this place/community is, for the time being, well-supported.

This work is not a "salvage ethnography". ${ }^{17}$ It is not meant to be "a memorial to [a] unique and remarkable people" swept away by what Davies calls "the worst devastation of all: progress" (Davies 2008:259). Although I share Troughton's conviction that "much has been lost or is being ignored" in the "reversal from rural to urban dominance," I do not share his resigned acceptance of this process as an inevitable part of the march of progress (Troughton 1995:299). This work intends to make a strong case for reconsidering what we mean by

16 The familiar kaleidoscope suggests movement, but also fragmentation and distortion. In order to focus attention on the qualities I need in this analytic tool I have tried to render it less familiar by coining a new spelling that highlights its capacity for movement, and the contingent/remporary arrangement of factors so as to point to new possible connections. I will explain the collide-o-scope as analytic tool at some length in Chapter Two.

17 "Salvage ethnography", often associated with those who studied aboriginal cultures in North America, gathered what it could of cultural artifacts, art forms, rituals, language, and dress as curiosities for display in museums in order to 'salvage' remnants of what the anthropologist assumed to be a dying culture. This work has been critiqued both for its Eurocentric assumptions about the inevitable march of progress, and for its complicity in documenting the demise of peoples and lifeways without intervening on their behalf. 
progress given the costs (human and environmental) of our current trajectory. I challenge specifically the effects of market-focused uniformity by highlighting the invaluable role of particularity in the collective resilience of a community like Shawville.

My research interrogates the impacts and implications of the current "naturalized order of things" on the present and future capacity for resilience of Shawville specifically, and smalltown agricultural Canada more generally. That interrogation contributes to what I believe to be the central question of social scientific inquiry: "What power, what interests, wrap this local world so tight that it feels like the natural order of things to its inhabitants?" (Singer 1994:26). This research unwraps and de-naturalizes the performance of 'being Shawville' in order to articulate and make explicit the factors currently supporting Shawville qua Shawville. Importantly, it points specifically to the potential impact of the globalising "order of things" on the factors that support particularity.

Several of the situations and/or factors that my research identifies as key to Shawville's resilience run counter to the market orthodoxy described above. It seems clear, for example, that being 'left behind' economically has been good for Shawville, increasing its resilience by insulating the community from external dependency, and forcing local economic diversification and flexibility. The real and perceived lack of mobility (the social distance between Shawville and Ottawa (as Canada's Capital), or Shawville and Québec City (as Québec's Capital), the interprovincial border, the terrible condition of the only highway) also contributes to the community's self-reliance. Its tight "garrison mentality" 18 plays a role in resilience by mitigating the risks in temporary or seasonal unemployment, heightening insistence on finding local solutions, and mobilizing local resources to meet local needs. The strong pull of family and connection slows the drain of people and resources just enough to

18 Northrop Frye famously describes Canadians as having a "garrison mentality", living in communities that focus inward, with their collars up and their backs to the cold (2004:14). 
allow the community time to adjust to demographic shifts. ${ }^{19}$ Each of these factors reinforces Shawville's particularity, thus contributing directly to the community's resilience.

Shawville offers a useful case study of community resilience precisely because its own persistence as a community is so pointed. It is English-speaking within a francophone political jurisdiction, rural in an urban-focused socio-political environment, resource-based in an increasingly knowledge-based economy, homogeneous within an increasingly diverse population. The odds seem stacked against it, and yet the community persists. Shawville's specific situation begs the question, 'Why and how has this persistence endured'?

\section{Shawville as Case Study}

In the winter and spring of 2011 , while I transcribed and analysed the interviews that inform this work, Shawville was in crisis. I worked under a growing sense of foreboding. I was concerned that my study might become the very "salvage ethnography", or nostalgic tribute I so recently decried. It seemed that the village I had set out to study as an outstanding example of resilience and survival-against-the-odds might be failing even as I watched. The 'crisis' centred on the closure of Shawville's only supermarket. Valu-Mart's thirty-two employees walked out on December 2, 2010, when contract negotiations with the store's parent company, Loblaw Company Limited, broke down. Within days the conflict seemed entrenched. The store was boarded up and a picket line became a permanent fixture on Main Street (The Equity 12/08/10:1).

Shawville's situation came to a head in the first week of June. The town's weekly newspaper (The Equity) announced that the striking workers had turned down the employer's "final

19 Karl Polanyi observed that "the rate of change is often no less important than the direction of the change itself" (2001:39). This important idea will surface again in later discussions. 
offer" and Loblaw Company Limited was threatening to close the supermarket "for good" (The Equity 06/01/11:1). On June $8^{\text {th }}$, responding to a sense of impending doom, Shawville's mayor held a town hall meeting at the local R.A. centre. The meeting was touted as the first of its kind. Shawville's council invited new ideas for revitalizing the town's much beleaguered businesses and rebuilding community spirit. As editorials in both The Equity and the regional bi-weekly paper Pontiac Journal Pontiac warned, it was a risky move (The Equity 06/08/11:4, Pontiac Journal 06/01/11:4). Frustration levels ran very high. The meeting would need a firm and skilful moderator. A retired high-school teacher with a well-founded reputation for competence and composure was asked to take the helm. More than a hundred and fifty people attended the meeting. Not one of them spoke out of turn or took the opportunity to grandstand. The Equity's reporter described the meeting as "relaxed", "cooperative" and "respectful" (06/15/2011:7).

Shawville's Mayor summarized the evening as "informative" (The Equity 06/15/2011:7), ${ }^{20}$ although, in truth, most of the ideas were far from new: spruce up Main Street, print a new map for tourists and put better signs out on the highway. None of the suggestions were revolutionary, but that is precisely what so impressed me. Just before the meeting The Equity's editor wrote: "I'm hesitant to say, as some have, that the store's continued closure could spell Armageddon for the town (Shawville and Pontiac have proven claims such as these wrong before)" (06/08/11:4). Those who spoke at the meeting were equally unready to pronounce the end. The ideas they brought to the meeting were too banal to presage Armageddon. They were the ideas of practical, practiced resilience, ideas generated by people who had previously experienced the cycle of collapse and renewal. Of course, the conversation continued out into businesses, parking lots and gathering places around town. Not everyone was reassured

20 The fact that the article reporting on the meeting was printed on page 7 of the newspaper edition illustrates how quickly the urgency that originally surrounded the meeting dissipated as soon as news that the supermarket would re-open became official. 
by the lack of novelty, in fact, many were frustrated by the dearth of new strategies to inspire growth. Others remained genuinely worried about the fate of their own livelihoods.

Suddenly, and with very little explanation, the crisis was over. On June 15, one week after the town hall meeting, The Equity announced: "Shawville residents will be able to shop at a local grocer again". A government-appointed conciliator brought the dispute to an end. Details about the agreement reached were limited. There was some very quier suggestion that the timing coincided suspiciously with the return of cottage traffic, ${ }^{21}$ and some less quiet commentary that the employees had settled for the very offer the company first made in early December so that the months of disruption were "all for nothing". Neither the lack of explanation, nor the lack of results, seemed to trouble either the newspaper's writer, or Shawville's council. The Equity reported that one councillor "got up and danced on the table" when official word that the store would reopen came through. The Mayor was more characteristically sanguine: "We were all trying to get the store open and that's what really counts. We can forget those six months... and get back to business" (The Equity $06 / 15 / 2011: 1)$.

Shawville's supermarket crisis highlights several facts that illustrate Shawville's particular context. Valu-Mart's significance to Shawville as the only supermarket, for example, provides a good measure of the community's size. The exaggerated impact of the store's absence reflects the community's age and relative lack of mobility. Shawville is a village of approximately fifteen hundred people and serves a surrounding community of perhaps five thousand. It

21 It seems clear that remaining closed through the summer would have had permanent repercussions for Valu-Mart. The seasonal cottage population represents a significant boost to the local population and economy. The local business people I talked to were matter-of -fact in observing that Valu-Mart could afford to inconvenience the 'locals' but not the 'cottagers'. When the highway which was washed out in a flash flood in June and remained closed all summer re-opened just in time for the Shawville Fair I saw a similar incentive at work. Fallout from the disruption of "Fair" traffic coming up the highway would have been serious. The Shawville Fair draws an annual average of 50,000 visitors over the Labour Day holiday weekend. 
is small, and it is aging. Valu-Mart was not one grocery store among many, but the only supermarket for a considerable distance. Despite collective and individual efforts to mitigate the loss by expanding the grocery selections at Shawville's 'Giant Tiger', pointing to local specialty shops (Pontiac Butcher Shop, Lorraine's Dairy Products, Pontiac Dairy and Fruit Wholesale), and even providing a subsidized taxi service to make travelling between the locations possible for Shawville's older and less mobile residents ${ }^{22}$ (The Equity 01/12/11:1), it was impossible to replace the practical convenience, commercial significance and symbolic importance of the grocery store as meeting place and vital community hub. The boards covering Valu-Mart's doors and windows made the entire village look and feel empty.

That the store's absence was felt across the region, from Ladysmith (The Equity 12/22/10:2) to Luskville (The Equity 01/05/11:2), refects Shawville's central place within Pontiac MRC, a position which is both geographic and symbolic. One striking feature of the Pontiac region is its lack of attachment to a significant urban centre. A combination of recent politics and historic relationships make the area self-contained and auto-referential (as in centred or grounded in itself). Despite the proximity of Ottawa-Gatineau, just over an hour away, the Pontiac does not fall within its metropolitan orbit. With the grocery store closed, most of the region's residents reverted to (or simply continued) shopping across the river in Renfrew, a 'cousin' community on the Ontario side of the Ottawa Valley. ${ }^{23}$

The labour conflict at the centre of the crisis just described points to the most intriguing aspect of Shawville's situation. Obviously, on one level, the dispute was between the employer and his employees, but, because the enterprise is a subsidiary of Loblaw Company Limited

22 The taxi project involved the cooperation of Shawville Council, the regional government's Local Development Centre (CLD) and Transporaction Pontiac. I particularly enjoyed the fact that Giant Tiger's owner installed a bench so that the taxi's passengers could wait comfortably.

23 This relationship is more thoroughly considered in chapter three. 
the small town grocery store's owner was represented at the bargaining table by a corporate heavyweight with its headquarters in Toronto. The members of 'Shawville Valu-Mart Unionized Workers', for their part, were represented by the Confédération des Syndicats Nationaux (CSN), the powerful province-wide Québec union to which they are affliated. Shawville's Valu-Mart is the only Valu-Mart franchise in Québec. Similar Loblaw Company holdings elsewhere in the province make up the "Provigo" chain of supermarkets. Valumart is an Ontario chain. The CSN, rather than negotiating in Montréal and under Québec labour law, found itself negotiating in Toronto (The Equity 06/08/11:1). The provincial border left the negotiators in an odd no-man's-land between jurisdictions (The Equity 06/01/11:1). Shawville's situation in "no-man's-land" on the Ontario/Québec border is a significant feature of the community's experienced reality.

\section{Overview of the Work's Format}

The body of this dissertation should be read as something between anthropology and history, political economy and rural geography. It both describes the Shawville I explored, and interprets the genesis and implications of some of what I found. I have tried to articulate what I know in a fashion that honours the truths that were shared with me in Shawville, and adheres to the criteria and expectations of the academy. This work's anticipated readers will come from diverse disciplinary backgrounds with their own sets of expectations. An advantage (and complication) of interdisciplinary work is that cross-disciplinary communication, like cross-cultural communication, pushes us, both as writer and as readers, to be self-conscious about assumptions, explanations and criteria. I use language self-consciously, mindful that words are always polysemic, both inside the academy where they become a short hand for discipline-specific assumptions, and outside, where they carry connotations and subtexts born of other associations. I rely on the reader also to be mindful of the assumptions he or she brings to the text. 
There are interdisciplinary scholars who are reassuringly optimistic that differing expectations need not be an obstacle to communicating from one discipline to another. Michael Quinn Patton, for example, writes that " $[b] y$ understanding the criteria that others bring to bear on our work, we can anticipate their reactions and help them position our intentions and criteria in relation to their expectations and criteria" (Patton 2002:266). Even so, communicating between fields of study (like communicating across varied individual experience), counts on the reader (listener) to make a reciprocal effort. Interdisciplinary writing challenges the "disciplined self" of both the writer and the reader to "think" from a new place. Because my intended audience is both multi- and extra-disciplinary the work will not fit comfortably within any one set of expectations. Again, the reader is asked to meet it halfway. My hope is that every reader will find the format navigable, even where it is sometimes unexpected.

The work is divided into six chapters. In the first chapter, above, I articulate the central claim of this dissertation, that particularity is necessary to both motivate and sustain community resilience. It is a community's particularity, its sense of being unique and significant, that gives it purchase as a site of meaning and meaning-making. Particularity is vital to resilience. I present the research problem I address and the questions that guide my inquiry. I introduce Shawville, Québec as my case study and describe the specific circumstances that situate that community particularly well as a place to interrogate the sources of resilience. I locate this work and its contributions within the literature examining English-speaking Québec, this part of West Québec, and rural Canada more generally, highlighting the particular contribution made by marrying social science with ecology in this inter-disciplinary study.

In Chapter Two I elaborate on my method, methodology and theoretical approach, clarifying the significance of the resilience theory models I have used, and describing the ways in which I have adapted them to further this research project. I describe the collide-o-scope I propose 
as an analytic tool, a mobile lens-in-motion intended to stretch our conceptual capacity. The metaphoric collide-o-scope challenges us to 'see' Shawville while keeping the near and far views, immediate circumstances and historical contexts, in relationship and in motion. I also introduce myself as 'researcher', describing my own location as both insider and outsider to Shawville's community, close enough to have been engaged by the community's particularity, and distant enough to know that there are questions that need asking.

Chapters three, four and five make up the body of this dissertation. In them I present the data I collected in Shawville in the form of excerpts from the interviews I conducted supported by collective narratives drawn from archival material and newspapers and contextualized within academic literatures drawn from a variety of fields. I have woven together story and scholarship to allow them each to serve the other as Appadurai's hypothetical "apparatus of recognition" (1996:158). Readers steeped in being Shawville will interpret theory through their experience, while those less familiar with the experiential context will use theory as a cognitive bridge into the world of being Shawville. The threads of story colour and animate the scholarship, while the scholarship draws the threads of story into shapes and patterns. The imagined movement of our analytic tool, the collide-o-scope, will help us to see experiences and perceptions, actions and reactions bumping one against the other. The dynamic interactions and implications of context and perception render visible the scaffolding supporting Shawville's resilience.

In Chapter Three I examine the role of geography in establishing Shawville's particularity and supporting its resilience. Shawville relies on story to affirm and reify its location inside the Ottawa Valley. Connections born of shared history, language and experience privilege an abstraction, overriding physical and political factors which could as easily have defined the community's place in space. For Shawville, being in the Valley community is positive 
and affirming in a way that being in Québec is not. By insisting on its place within the Ottawa Valley, the community takes possession of its status as a key player early in the Canadian nation-building project. In contrast, within Québec the community is marginal and insignificant. The veracity of Shawville's perceived membership in The Valley and/or its exclusion from Québec is not important. I have sought no external confirmation of Shawville's standing in either 'the Valley', or Québec. Whether or not it is 'true' beyond Shawville's "meaning-making" framework is not the point. The community's physical and psycho-social location outside and inside 'The Valley', inside and outside Québec, supports its claim to particularity, and strengthens the powerful centripetal force that enhances the community's resilience. I argue that the very ambivalence of its location provides the community with a claim to distinction and thus serves the community well, affirming its particularity and enhancing its resilience.

In Chapter Four I put Shawville's political economy under the collide-o-scope lens. What we see there tells a story of neglected infrastructure, mobility concerns, and industrial development and employment opportunities that come and go. The historic relationship between farming and forestry mean that work has been experienced as cyclical and seasonal. The more recent experience of mills and mines that have opened and closed echoes a similar on-again off-again cycle of (un)employment. The lessons of that story play out in the commonly held certainty that "useful skills" can be put to work even when "jobs" are unavailable. While all agree that a large-scale employer has been (and would be) good news, there is also a sanguine acceptance that life goes on in times of unemployment. Being able to fall back on self-reliance and the possession of "useful skills" has strengthened Shawville's resilience. Slow economic growth has also supported the community's resilience by decelerating the momentum of change enough to give the community time to take changes in stride. Being "left behind" means that the town feels comfortingly familiar to 
returning retirees, a substantial and significant resource in Shawville's current economy. Being "left behind" means that the centripetal force of the community's resilience basin is still strong. Shawville's particularity remains intact and attractive, a factor that contributes to the community's resilience.

Exploring the themes of self-identification and identity construction in Chapter Five reveals a story of concentrated interrelationships and a long shared history at the heart of the community. The stories I was told in Shawville corroborate Bruce Elliott's description of the chain migration practiced by the Irish immigrants he studied, relatives and friends following and being followed by relatives and friends (1984:215), so that families and neighbourhoods were reconstructed in the new settlements. Shawville's "original" families trace their ancestry back in time and space through many generations and multiple migrations. Its deep and well-seated foundation has made a considerable contribution to the community's stability and its capacity for resilience.

The interweaving of theory, interview narratives and analysis in Chapters three though five allows the text as a whole to privilege story as the site of meaning-making. I follow Niles in insisting that stories do not just "decorate" the world we inhabit, they "constitute" that world (Niles 1999:8). Homo narrans uses stories (fully developed narratives or bits of gossip) to interpret and make sense of his or her surroundings and experiences. Stories reveal connections between cause and effect that have been assumed by the story tellers, and point to other possible connections that have not yet been made. This research made use of story as a window into what it is to "be Shawville" in order to draw out of that performance clues to the community's resilience. The stories Shawville tells point to the community's certainty of itself as distinct and significant. They support my central claim that resilience requires particularity. 
In the final Chapter I return resilience theory to its context within environmental studies in order to clarify the connections between the theory's insights about the conditions for resilience in ecological systems and the characteristics and capacities that I claim contribute to Shawville's resilience. Resilience theory's good 'fit' as an explanatory framework for community resilience situates social systems squarely within the cycles and constraints of the natural world. Acknowledging the importance of this re-situating puts this work in line with Latour's call to think past the false division of the social and the natural. The narrative construct that declares us independent of natural law prevents us from seeing our current, precarious position sufficiently clearly.

In the final section of Chapter Six I take up Troughton's challenge to examine existing rural development policy and consider potential alternatives that would better support the resilience of rural communities. Shawville's particular case made that community's persistence stand out, but in many ways it exemplifies the situation of other rural place communities across Canada. I close this work with a call for rural development policies that value the diversity of small communities and support not only their economic viability, but the particularity of their relationships and their place as well.

\section{Conclusions}

This project set out to identify the factors supporting Shawville's resilience. My research documents the significant roles played by geography, political economy and the community's self-conscious self-identification as distinctive. Shawville, as a particular place/community, experiences, reproduces and projects its own particularity with enough conviction to both motivate and enable the community's resilience. As the chapters that follow will show, particularity is inscribed into the place, cultivated in the specifics of the community's 
politico-economic situation, and self-consciously constituted in the quotidian activities of "being" Shawville. The work of inscribing, cultivating and constituting particularity responds to a need for the marked spaces of particular place/communities as sites of meaning-making. The community's resilience relies on its capacity to make particular meaning.

Shawville's exaggerated precarity, perched uncomfortably in multiple border spaces, made it a good place to study resilience. The community sits on the line between French and English Canada, between urban metropole and hinterland periphery, between productive and recreational (re-creative) space. While its exaggerated instability makes Shawville's supportive scaffolding helpfully conspicuous, small towns and agricultural communities across Canada face their own challenges and instability. I suggest that the supports Shawville relies on play similar roles supporting resilience in similarly distinct communities elsewhere in rural Canada.

In the next chapter I discuss research methodology and method. I define what I mean by interdisciplinarity and justify my insistence that this project be interdisciplinary. Having established my approach to research (methodology), I then describe my research activity in Shawville, and offer a brief reflection on conducting research among my neighbours. My method drew on a multi-disciplinary 'tool kit' including observation, semi-structured interviews, archival research, and Shawville's weekly newspaper (The Equity) to ask, "how is this community able to absorb change without changing its own form"? and "What supports Shawville's resilience"? Using these tools, I gathered data and impressions about what it means to 'be' Shawville. My goal was to determine the source or sources of Shawville's resilience. 
Chapter two also returns to resilience theory, introduced briefly in the opening pages of this chapter. I clarify the ideas embodied in the models of adaptive cycles and resilience basins drawn from resilience theory, and explain their significance to the present study of Shawville's resilience. Holling's (1973) insights shaped both the way I understood the questions I was asking, and how I interpreted the answers they elicited. His models inform an understanding of resilience that allows us to step past preconceptions about adaptation and progress and study Shawville's resilience as the community's ability to change without changing what it means to be, specifically and particularly, Shawville. 


\section{Chapter Two: On Method and Methodology}

\section{Introduction}

This chapter discusses the practical, theoretical and ethical considerations that influenced my choice of research methods. It establishes a rationale for my choices (methodology), and then describes the research process as it unfolded in Shawville. I describe what I did and how I did it, documenting how the tools and research activities I chose to use were deployed (my research method). The discussion then engages the process by which I analysed the collected data, describing the collide-o-scope 'slides' I used to sort the observations, impressions and information I had gathered by theme. The three categories (geography, political economy and socio-linguistic identity) represent the factors I believe to be at play in Shawville's selfidentification. The chapter ends with a discussion of the pros and cons of "insider" research in which the subject of study is often very like the researcher's self. There are specific risks and benefits to doing research that involves "going observationalist" (Labaree 2002:116), that is, stepping back from one's own environment in order to explore it as a subject of scrutiny (Labaree is playing with the phrase "going native" which is obviously its opposite). In research that challenges us to critique our own norms and assumptions what we learn is often as much about ourselves and 'our kind' as about the posited 'other' we are treating as our subject.

Throughout, Chapter Two focuses on the importance of questions. It highlights the role of questions in shaping what we as researchers look for and how what we look for affects what we see. Questions share a status with stories as the vocabulary with which we think, and the content we think about. The methodology discussion below justifies this project's interdisciplinarity. In order to respond to the question, "What supports Shawville's 
resilience?" it was necessary to look at the community from the disparate vantage points of geography, political economy, and identity studies. To adequately conceptualize Shawville's complex context it was also important to work between disciplinary categories, accessing 'un-disciplined' inter-disciplinary space. In order to capture the idea of multiple perspectives in motion I introduce the metaphor of a collide-o-scope, a poly-focal, mobile lens especially conceived to help us 'see' Shawville in all its complexity. The collide-o-scope is an invaluable analytic tool because it stretches our conceptual abilities and opens up new potential questions. Interdisciplinary research, because it works both across and between accepted disciplinary frameworks, makes forming relevant questions part of the research problem.

\section{Methodology}

That it is useful to approach a complex problem like 'Shawville' as a multi-disciplinary endeavour seems obvious. The project of ascertaining what supports this community's resilience, its ability to absorb change without changing state, spills over the boundaries of multiple disciplines. In order to adequately conceptualize "Shawville" as a particular place/ community I followed the threads of my research onto territory traditionally associated with geography, political economy, history and anthropology, borrowing conceptual categories from each of these disciplines in order to 'thicken' (Geertz 1973), my representation of Shawville and its context (see figure on page 34). It is important to understand this community in this particular moment (as is true for any particular place/community) against the backdrop of a wider swath of time and space. 
HISTORY

Protestant Irish land settlement

Ottawa Valley lumber transportation

Québec French nationalism

GEOGRAPHY

Continental America

Canada

Quebec

Ottawa Valley

linguistic contact zone

border space

cottage country

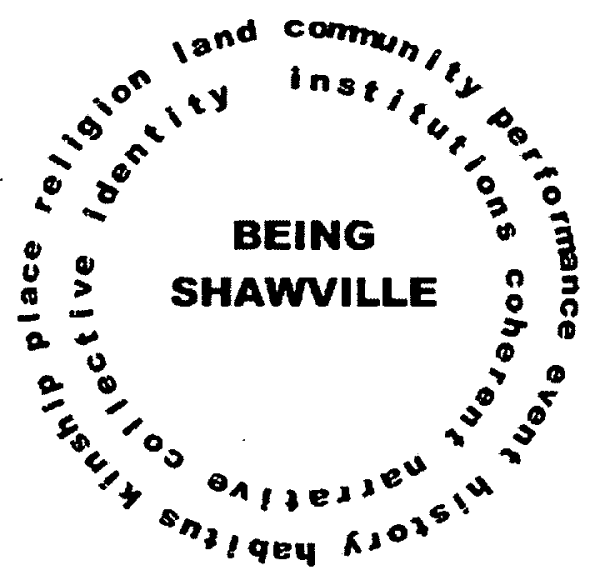

POLITICAL ECONOMY

identification with logging

'resource region' tourism

global marketplace

Anglo-American 'West'

\section{ANTHROPOLOGY}

privilege lightness detachment mobility hydroponic

global Empire lingua franca "naturalized"

de-ethnicized hegemonic worldview 
My investigation began with the quintessentially post-modern question, "How is Shawville?" One of the first ideas I encountered as a graduate student was the three-part mantra: treat every noun as a verb (ask what does Shawville do?), make it plural (consider the many faces and expressions of Shawville - the many Shawvilles), and pose it as a question (Shawville?). ${ }^{24}$ How is it? How is it still here (in this corner of Québec - in this urbanized Canada)? How does this community endure?

Shawville sits at the complex intersection of multiple experiences. It is inside and outside Québec, outside and inside the Ottawa River Valley. It is both periphery and core, productive land and picturesque countryside. To plan an exploration of this complex terrain I drew on Michael Patton's methodological "paradigm of choices". Patton argues that in order to be relevant to a complex situation, i.e. flexible and responsive, "methodological appropriateness [should be] the primary criterion for judging methodological quality" (Patton 1990:39). With Patton's challenge to make research responsive in mind, this work endeavours to be inter-disciplinary, reclaiming the margins between disciplines for what Moran (2002) calls "un-disciplined" research. I look to the margins and peripheries of academic orthodoxy to find the uniquely creative spaces Foucault (1970) famously described.

I drew on theory and methods from anthropology, political economy, history and geography to build a conceptual tool appropriate to the task of examining the mixture of ideational and material factors that constitute 'being' Shawville. The disciplines together create a poly-focal lens that draws multiple factors into focus; the space between them allows the lens room to turn, breaking and making connections, shuffling and re-weighting the factors at play. In

24 Acknowledging my particular mobilization of the town as a metonym for a distinct identity I will forego the plural (s) and look for other ways to clarify the understood multidimensionality of "Shawville". A truly post-modern study would begin by questioning the reality of Shawville itself - I have consciously chosen to 'assume' a particular instance of Shawville based on the experience of a Shawville shared by the people I interviewed. I rely on the premise that our collective imagining of the village/community constitutes its 'reality'. 
this analogy interdisciplinary research becomes the mobile, poly-focal lens of a collide-oscope (see figure on page 37). It is an analytic tool "sufficiently quirky" to satisfy Appadurai's challenge (1996:33) and allow us to hold in our mind's eye the interlocking pieces and layers of the "fractal and polytheric" reality we experience (Appadurai 1996:46).

Unlike a microscope or a telescope which are both designed to study a static slide, a collideo-scope allows us to include motion. Its fictive lens is well-suited to thematic analysis because it holds the near and the far views of Shawville in relationship to one another, while keeping those relationships fluid and contingent. The collide-o-scope's motion challenges our assumptions about cause and effect, action and reaction, stasis and motion. It will serve to push our conceptual abilities beyond their own limitations by changing the shape and dynamic of what we see. The tool, though imaginary, is important. What we see drives the questions we think to ask. The collide-o-scope lens pushes us to see differently.

As a child I played with an unusual kaleidoscope. It was made like a microscope, with the eye piece fixed in place above a tray. Where the slide would have been on a proper microscope, mine had a shallow dish turned by a little crank. I had a box of thread ends, buttons and beads, and could create endless new combinations in the little dish from my treasure box and then spin the 'slide' I had created under the mirrored lens. The possible combinations of colours, patterns and movement were endless. A collide-o-scope lens allows for creative chaos. It reveals patterns, motion and unexpected connections. It is the quality of motion that makes it a useful tool in this project.

The themes drawn from my study of Shawville's characteristics and context are the thread ends and buttons in motion under the lens of the imaginary collide-o-scope I have posited as an analytic tool. The 'data' assembled in the slides include the stories and impressions I collected in 


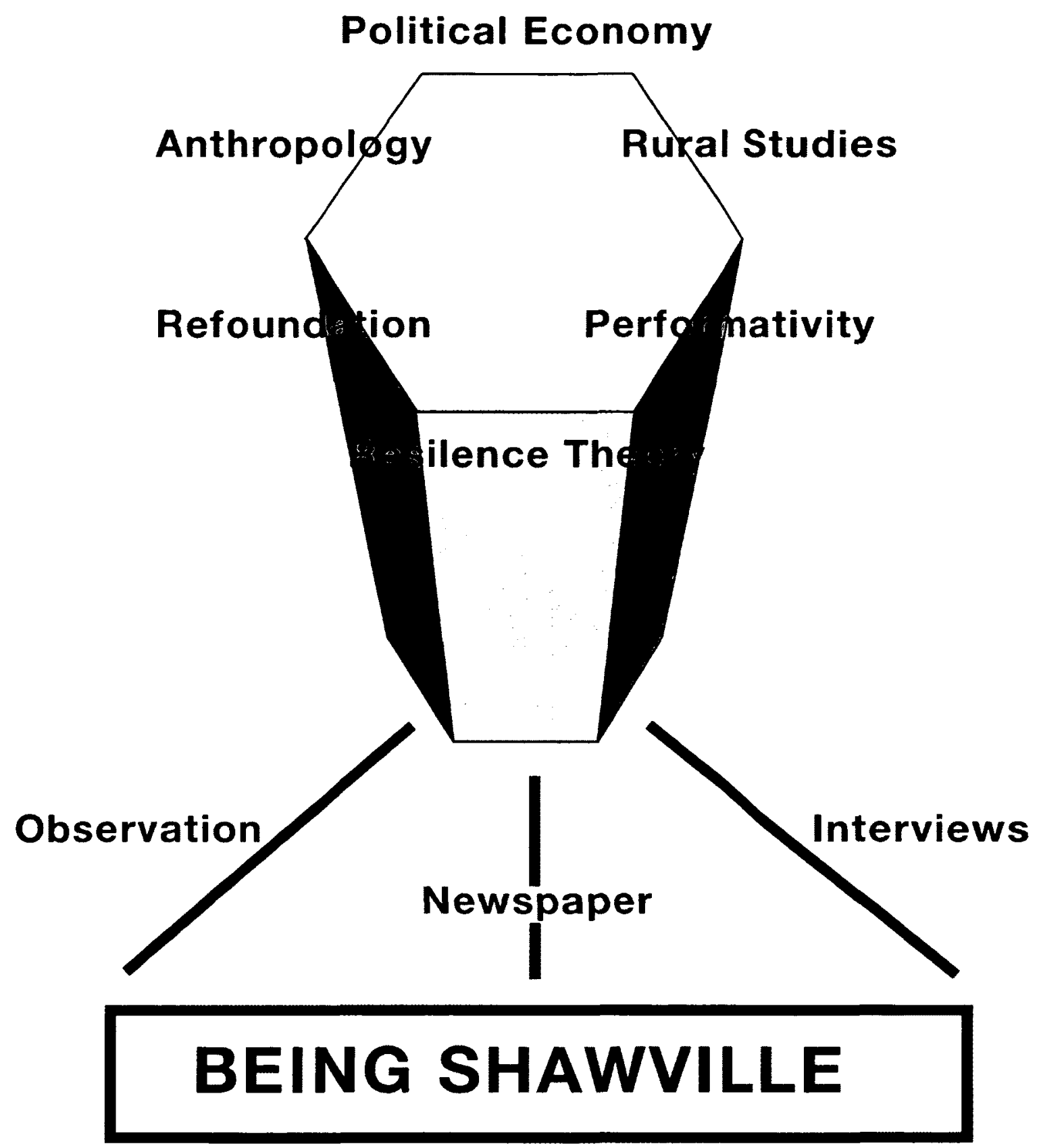


my field work, the assumptions of resilience theory, and the findings and interpretations of prior scholarship. There are many rich literatures from which to collect theories and observations to explore with and against what I learned about Shawville in Shawville. There are many literatures that speak to Shawville's context and offer ways to interpret the community's resilience. A variety of literatures presented themselves as possible ways to frame the 'slides': literatures considering Anglophone Québec, Irish immigration, Québec history, Ottawa Valley history, the contests and debates within rural studies, and the study of border spaces inter alia. The three 'slides' I have chosen as a starting point for my analysis reflect my claim that Shawville's particular location, politico-economic situation and self-identification as distinct support the community's resilience. My thematic analysis of the research data I collected grouped my findings into loosely defined categories I labelled: geography, political economy, and identity.

\section{Getting the Questions Right}

The strongest case for interdisciplinary research lies in the flexibility of undisciplined questions. Questions matter a great deal. The questions we ask, like the stories we tell, become the tools of our collective imagination. ${ }^{25}$ The questions that get asked (and the questions that do not) limit and shape the topics that get examined. They speak volumes about the assumptions and values of individual researchers. They reflect the worldview and concerns that drive the agendas of research agencies and funding organizations. Without the 'right' (i.e. relevant and incisive) question it is quite possible for an answer to be altogether meaningless. At its best, interdisciplinary scholarship incorporates the forming and framing of questions into the research problem itself.

25 Daniel Francis claims that, "The stories we tell about the past produce the images we use to describe ourselves as a community. If we are not telling ourselves the right stories [i.e. stories that adequately reflect who we are, and explain to us where we are], then we cannot imagine ourselves acting together to resolve our problems" (1997:176). I want to suggest that questions have a similar significance in both reflecting where we are, and in determining future directions. 
There are very particular constraints on the questions expected of academic research. Researchers must demonstrate that the questions they plan to ask are questions that can be answered. They must outline specifically how they plan to look for those answers, how they will recognize them when they find them, and how they will communicate them in their finished work. The project proposal for this study, for example, pre-supposed the significance of place, political economy and identity in shaping Shawville. Those presuppositions shaped the questions I prepared, influenced the people I arranged to interview, and determined the literatures I addressed (taking into account their definitions of what counts as evidence and structuring my work to conform to their expectations). Had I started from a different assumption, had I hypothesised for example that Shawville was a product of long association with the First Nations people of the Outaouais and their common experiences in the timber industry, ${ }^{26}$ questions, answers, interviews and format would all be different. The story our research tells depends a great deal on where and when we choose to begin, and the question(s) we choose to address.

Posing questions that can be answered by following a thoughtfully constructed plan renders a proposed project 'doable'. The problem with this process, the sharpening of the original, admittedly 'fuzzy' questions into finely tuned research instruments, is that it pushes scholarship to think backwards - to begin with the answers it anticipates, through the data that might prove salient, to the questions that will uncover the data it expects. The process privileges our preconceptions by default. There is no way within this conventional framework to operationalize and thus validate a question whose answer we cannot imagine. This limitation remains one of my principal concerns as a researcher.

26 A case which might be made beginning with a reading of Michael Newton's 1991 study entitled Some Notes on Bytown and the Fur Trade. 
Thinking backwards is troubling on two counts. The first is that a finely-honed instrument cannot be expected to find what it is not looking for. We cannot count on our specialized questions to draw out or to point to the unexpected, let alone to signal its significance. Acknowledging the difficulty of recognizing something beyond our cognition, Appadurai posits the need for an "apparatus of recognition" (1996:158), a sort of adapter cable, or translation machine that would shift our 'wave length' and allow us to re-cognize, to re-think what we know. Lacking such a device we can only remind each other as scholars that we do not, in fact, know exactly what we are looking for. It is difficult to write uncertainty into a project, but we can be prepared to accommodate it, and even to welcome it, in our work (Kouritzin, Piquemal and Norman 2009:211-212).

I anticipated that the multidisciplinary supervision of this project would go some way toward mitigating the problem of thinking backwards from a presumed scenario because it inherently juxtaposed and thus destabilized disciplinary expectations. Moving from one theoretical stance (one discipline) to another changes the whole frame of reference, it becomes not only a question of competing explanations, but of what 'counts' as evidence, what needs to be explained, and even how an explanation must be structured in order to be heard (Tilly 2005:30). Between disciplines, questions, answers, and what counts as 'knowing' all participate in the discussion rather than containing it. Beginning to think in the spaces and contests between disciplines has the potential to open up new questions and recognize new answers.

The second concern raised by 'thinking backwards' from expected outcomes to salient questions is that when we allow our questions to be shaped by anticipated answers we risk reinforcing and reproducing accepted and acceptable perceptions of reality. It would be bad enough to think backwards if all that was at stake was the possibility of missing a particular bit of information or failing to make a particular connection, but facts are not things that 
can be missed and what is at stake is the business of truth construction itself. While in theory the social sciences acknowledge that our 'reality' is an inter-subjective product which we as human beings participate in producing, in practice, particularly as social 'scientists', we have yet to shake the idea of objective data that can be collected and analysed. ${ }^{27}$

The possible trap of 'thinking backwards' to uncover expected answers and/or reinforce prior assumptions is particularly troubling in the context of a study of rural resilience. Research exploring rural places and people too often accepts a view of rural as a "residual category" (Bryant and Joseph 2001:132) in which "the rural is always understood with respect to, and immediately implies, the urban... the categories are dichotomous, with urban/metropolitan areas defined first, leaving rural/nonmetropolitan areas as residuals" (Bell 2007:405). A significant number of such projects focus on rural "development", asking how to bring rural places and people into the present as if their current lived experience exists in some sort of past. ${ }^{28}$ Others study rural "sustainability", asking how best to pour the missing resources into needy spaces. An accurate study of "Shawville qua Shawville" required a way to see this particular place/community on its own terms, present in this time and place, and supported by its own particular mix of circumstances and resources. To address the need for models that value and support rural places/communities this research sought to resist the trap of using the familiar, dichotomous assumptions of urban/rural, progressive/pre-modern to "think with".

27 This discussion appears in part in Lyndal Neelin, A Case for Interdisciplinary Studies: In Praise of the Polyfocal Lens, published in the conference proceedings for Diverse Engagement: Drawing in the Margins Interdisciplinary Graduate Conference Cambridge University U.K. June 28-29 2010.

28 Using Holling's model of adaptive cycles to think with moves us beyond urban modernity's predisposition to conceptualize the rural as a pre-modern survival. It is not possible to see rural reality as having been 'left behind' if we accept that adaptation, being cyclical, is not 'going' anywhere. 


\section{Research Method}

Discovering what counts as a question is central to the work of a researcher. The careful rendering of a research proposal that fulfilled the requirement for operationalized questions and a clear agenda felt to me like poring over a recipe before checking the cupboards to see what ingredients were on hand. As my account of actually doing research in Shawville shows, even questions prepared based on some initial exploration of the pantry on my own (prior knowledge and preliminary research) did not stand up well in the face of local experience and perceptions. My own assessment of the items on the pantry shelves did not guarantee "relevant and incisive" questions. Those came only after hearing from individuals within the community. Paying attention to the "everyday/everynight knowledge" (Smith 1989:39) of those steeped in the art of being Shawville, I gained a sense of which categories 'counted', and which questions were worth asking.

My inter-disciplinary project was vetted by Carleton University's Research Ethics Board (CUREB) which approved my proposal to study community resilience employing Shawville, Québec as an appropriate case study. As per the research proposal I submitted to CUREB my research included both interviews and observation. It was conducted in the Shawville Archives, the Town Hall, main street cafés, and a doctor's waiting room, as well as various sitting rooms, kitchens and backyard decks where people generously hosted me and answered my questions. It also took place less formally in the grocery store aisles, on the side walk and in parking lots. Whether actively engaged in research (combing through back issues of the local weekly newspaper (The Equity) and reading local histories and publications) or simply present as an interested observer, I watched for and recorded the topics that surfaced in conversation most frequently. In published local accounts, newspaper reports, editorials, 
letters to the editor ${ }^{29}$ and the stories recounted to me in informal conversation I sought confirmation of the themes emerging from my interview data. Wherever possible, I sought to reinforce the impressions generated in the interviews - the "inter-subjective" constructs negotiated between interviewer and interviewee - with supporting material drawn from the community archives and the local newspaper. This "triangulation" was not intended to test the 'truth' of individual accounts so much as to situate them in the fabric of the town's collective narrative. By cross-referencing collective and individual impressions I hoped to ensure the themes I identified would prove both valid and useful.

I conducted and recorded eighteen semi-formal interviews. The sessions were each ninety minutes or longer. The initial list of possible interviewees was compiled by the simple expedient of identifying what I saw to be distinct and significant sectors of the community and attaching one or two names to each one. The list included: the hospital, the schools, the Shawville newspaper (The Equity), local councils (Shawville Village and Clarendon Township), the Shawville Women's Institute, the Pontiac Historical Society, farmers and businesses. As noted above, I deliberately excluded the churches from my list because I felt that including them in this study would overwhelm the project. A study of the role of religion and the churches in Shawville would constitute a mammoth undertaking in its own right. ${ }^{30}$ Religious faith and religious identification are, unquestionably, part of the fabric of being Shawville. The importance of religious "commitment" is acknowledged in the number of times it surfaces in the interviews as a significant part of individual and collective

29 I read every issue of The Equity for the years $1970, ' 71, ' 76,77$, ' $80 \&$ ' 95 , beginning on microfiche in the newspapers offices and moving to the archives when I learned that they had paper copies I could access. I also read through two binders of clippings helpfully assembled by Margaret Fierobin, an archives volunteer, on the topics of local agriculture and sawmills. Pontiac Archives files (Agriculture 2005/ Sawmills 2006).

30 A study of Shawville's resilience presupposing the central role of religion would have been a sensible alternative approach. It too (like the above posited project considering the community's relationship with their First Nations neighbours) would have posed different questions, suggested different interviewees, and arrived at different findings. 
narratives. The community's identification as Protestant is a very significant part of its particularity. Religion and religious affiliation are significant markers in Shawville's capacity as a site of interpretation and meaning-making.

In assembling the list of names that might represent the sectors I wanted to explore I tried to include a range of ages, educational backgrounds, and life experience, as well as involve men and women in equal numbers. My interviewees were not randomly chosen. Instead, they represent what Patton calls a "purposeful sample" (1990:169), a group selected as potentially “information-rich". My sample group deliberately represents a cross-section of 'location' and status within Shawville's social fabric, while focusing on individuals instrumental in shaping that fabric. The patterns that emerge from such a deliberate sample, Patton suggests, point to core experiences and key features of the community (1990:172). My interviewees came through with information, patterns, and insights as predicted.

I was not able to speak to everyone who was on my first list of prospects. While few people declined outright, several people deferred until it seemed inappropriate to ask again. Others were added to the initial list, either to ensure that the sectors I had identified were covered, or as a response to repeated suggestions that "I must speak to" a particular person. The interviewees who became my sample group ranged in age from their late 20 s to early $90 \mathrm{~s}$ with an irregular breakdown across the decades in between. The sample group included twelve women and ten men. Four of the interviews were conducted with couples.

\begin{tabular}{|lccccccccc|}
\hline \multicolumn{10}{|c|}{ Interviewees in Shawville } \\
\hline Age by decade & $20 \mathrm{~s}$ & $30 \mathrm{~s}$ & $40 \mathrm{~s}$ & $50 \mathrm{~s}$ & $60 \mathrm{~s}$ & $70 \mathrm{~s}$ & $80 \mathrm{~s}$ & $90 \mathrm{~s}$ \\
Distribution of interviewees & 2 & 1 & 4 & 3 & 4 & 4 & 3 & 1 \\
\hline
\end{tabular}


The information in the next few paragraphs could also have been summarized and presented as numbers in a chart. I have chosen instead to express it in the form of brief cameos in the interest of preserving a greater sense of the individuality and 'reality' of those who shared their stories with me. I have not changed their names or tried in any way to obscure identifying information. Instead I received the blessing of Carleton University's Research Ethics Board to waive conventional concerns about anonymity and confidentiality given the benign subject matter of the interviews, and the impossibility of safeguarding anonymity in the small town context of my study. Each interviewee signed a consent form in which they agreed that their name would be used. The information about education, work and life experiences in the sketches below locates the individual speakers within Shawville's social fabric and will prove salient to interpreting their separate and collective accounts of what it is to 'be' Shawville."

Bill and June $(21 / 04 / 10)^{32}$ are both retired school teachers. They taught at Pontiac High and Dr. S.E. McDowell Elementary Schools respectively. Bill grew up in Shawville. One of his earliest summer jobs was at the nearby Hilton Mine. June is from New Brunswick. They met while Bill was away for a time, teaching in the Eastern townships. Family ties and a job prospect brought them back to Shawville in 1971 .

Joan and David (06/02/10) also taught at Pontiac High School in Shawville. David was the school's principal in the 1970s. Joan is a force to be reckoned with on the Shawville social scene. She is the dynamo behind myriad local theatre productions, cabaret evenings and fund raising events with David's able and enthusiastic support. Joan grew up in the neighbouring village of Bryson. She met David while studying in Montréal. David takes credit for "bringing her home".

31 The town of Shawville has also been clearly identified because it is Shawville's particularity, its geographic location, historic role in the timber industry, Irish heritage erc. that give substance to this study.

32 Date of interview 
Holly and Jared (08/10/10) are in their late twenties, the youngest members of my sample group. Their two young children are the sixth generation living on Jared's family farm. The two grew up locally, attended Pontiac High School in Shawville, and went away to study nursing and agriculture intent on bringing those skills "home" to build a life here. As well as participating in the family's turf agronomics business Holly and Jared hold the quota for a 5,000-hen egg farm. Holly gave up nursing in favour of participating in the family business because it was an easier fit with mothering.

Dorothy (21/04/10) and her husband live in Norway Bay, a community of holiday cottages some $14 \mathrm{~km}$ from Shawville village. She trained as a nurse in Kemptville "years ago" and worked for a year in Ottawa before returning "home". She recently retired from teaching in the secretarial and accounting programme offered by the West Québec School Board.

Margaret $(08 / 02 / 10)$ is a retired primary school teacher, a long-time member of the Shawville Women's Institute, a "farm wife", and a Shawville "original" who can trace her ancestry back to 'Tipperary' Thomas himself. She has lived in Shawville all her life, except for a brief stay at Macdonald College in Montréal to earn her teaching certificate.

Gordon (06/07/10) teaches history at Pontiac High School. He lives with his young family in Bristol Township where the Grahams have deep roots and a strong presence. We will encounter Gordon Graham several times through his writing: I have cited both his M.A. Thesis(1994) entitled, "Our surest hopes of prosperity": economic development in Pontiac County's railway era 1880-1920, and a booklet commissioned locally to mark the year 2000 entitled, Suffering from a Want of Communication: A History of Transportation in Pontiac County. 
Debra $(05 / 05 / 10)$ grew up on a farm just outside Shawville, went away to study, and returned. She is the vice-principal of Pontiac High School and the mother of two young children.

Albert $(05 / 06 / 10)$ is now the Mayor of Shawville after a long career with Hydro Québec, first as an electrician and then in management. His other work experiences include college schooling as an agricultural 'Record of Performance' (ROP) inspector, an apprenticeship with his father as a brick mason, and time in the Levack Mine near Sudbury.

Jack and Elaine (05/05/10) have three sons, grown and moved away. Jack is the Mayor of Clarendon Township. Elaine works in W.A. Hodgin's 'Home Hardware'. (I also spoke to her as a member of the Shawville's Women's Institute). Jack started at the mill straight out of high school. He was "never tempted to go away". He worked for 37 years at the Mill and then moved on to local politics.

Dan (05/10/10) was Pontiac branch president of the Québec Union des Producteurs Agricole $(\mathrm{UPA})^{33}$ at the time of our interview. As a high school student he lived in Ottawa. After post-secondary studies he chose to move back to the Pontiac where he "married into" a dairy operation he now runs with his wife and father-in-law. He has a young family, including a baby girl born just days after our interview.

33 The UPA (the Farmer's Union or Union des Producteurs Agricoles) is an organization with significant political clout. In 2005 it had a membership of 43,000 men and women. Recently, in 2010, the UPA won a campaign against a proposed amendment to the funding formula for income stabilization insurance - income insurance meant to mitigate the gap between production costs and 'farm-gate' prices. The government wanted to exclude the bottom $25 \%$ of farms from the calculation of costs, a measure they claimed would save them $\$ 80$ million dollars. In prorest, the UPA barred access to the province-wide network of skidoo trails, upsetting Québec's tourism sector. The government stepped down on the proposed change in funding and the skidoo trails were opened just in time for the first snow fall of last season (memoireduquebec.com). 
Robert $(05 / 18 / 10)$ is a retired farmer with deep roots in the Shawville community. After completing a BA in geography at Carleton University he "came home" to take over the family farm. As he says, "There is so much around us here that I've never felt the need for it [moving away or having more]. I've lived my whole life here".

Pat $(07 / 10 / 10)$ is a dietician. She has offices in the hospital in Shawville as well as several of the region's CLSC clinics from Quyon to Fort Coulonge. The catchment area for her services is vast, so Pat "takes her show on the road" providing outpatient clinics that give her intimate access into the lives of the community. She has lived both in and away from Shawville, as well as overseas and in various other parts of Canada.

John (09/15/10) has practiced medicine in Shawville since the early 1980s. He had 27 years of insightful observation of this community to offer to my inquiry, as well as his other invaluable experience in rural medicine more broadly. Dr. Wootton is President of the Society of Rural Physicians of Canada and editor of the Canadian Journal of Rural Medicine.

Heather (07/30/10) arrived in the Pontiac just after the Parti Québécois election victory in 1976. She and her husband were drawn to Shawville by a sense that big events were unfolding and that "here was a place they could do some good in the world". Heather joined the family-owned local newspaper business. She now owns and publishes The Equity.

Venetia $(08 / 12 / 10)$ is a member of the Pontiac Historical Society and a founding member of the Shawville archives. She insists that she is "not from here" although she lived in Campbell's Bay (twenty minutes up the highway) for thirty years, and raised a family there. Venetia has a reputation locally as an historian and storyteller. 
Elsie $(08 / 12 / 10)$ is another of the 'principals' at the archives and a member of the Pontiac Historical Society. She moved to the Shawville area from Huntingdon Québec to teach school in 1948 and has "lived here ever since". She farmed and raised a family in Thorne Township, just north of Shawville village.

Pearl $(09 / 21 / 10)$ is over 90 and both amused by and proud of her own longevity. She is a volunteer in the archives, a member of the historical society and takes a special interest in the local museum as someone who knows what the artifacts are called, how they were used, and where they came from. Pearl rarely travels as far as Ottawa and thinks of the city as a long way away.

William (03/02/11), although into his 80 s, shepherds his own parish, preaches on Sundays and rides his bicycle downtown to run his errands. Rev. McDowell is a Methodist minister, a role that clearly defines his sense of self. He grew up in Shawville, the son of a physician (the Dr. S.E. McDowell the elementary school was named after). William went away to university in the mid-1940s ("just after the Great War") and fulfilled his ministry elsewhere before returning to Shawville after his official retirement.

The demographic profile of this 'purposeful sample' reflects a lopsided lean towards being older than 65, female, and professional that is consistent with Shawville's makeup. As will become evident in the interview data about Shawville, the village was home to the management class of both the mills and the mine. The principal local employers have, for some time, been the schools and the hospital. Farming has become an occupation that requires post-secondary schooling and on-going re-certification to meet the exigencies of government oversight, banking requirements and the financial and physical management of a complex 'business'. The 'lean' toward more rather than less education among the sample group also reflects the relative comfort of my interviewees with participating in my project. 
I sought out willing participants who would not feel intimidated by being interviewed, and would perchance enjoy the experience of engaging with my questions. Certainly all of my interviewees numbered among the social "movers and shakers" of Shawville. While some interviewees were less comfortable than others, I like to think that I succeeded in large part. In some cases, I felt that I began at a disadvantage, approaching respected and knowledgeable members of Shawville's community as someone who came from away.

While the "purposeful sample" I interviewed reflects what I believe to be a significant facet of Shawville's self-identification it clearly excludes alternative experiences of living in and around the community. First Nations, French-speaking and non-Irish voices are notably absent, as are the perspectives of various other populations potentially marginalized or written over by the self-confident particularity Shawville projects. Given the limited scope of my interview sample (even stretched as it was by informal conversation and newspaperbased research) I cannot claim to present a definitive picture of Shawville, only to reflect the Shawville that was shared with me, a way of being Shawville that resonated across a diverse group of people who call themselves "Shawvillians".

I have lived just outside Shawville (geographically and socially) for twenty years so most of the people I spoke to were known to me in some context or another, as I was known to them. At the very least we had seen and acknowledged each other across the auditorium at school events, or stood together in the grocery store line-up. Everyone I spoke to seemed genuinely interested that I wanted to write about their community and willing to contribute their thoughts about Shawville to the project.

I call the interviews I conducted 'semi-formal interviews' though I hesitate, in fact, to claim any level of formality for conversations that invariably took on a life of their own. Even as 
I write the word 'conversation' I can hear the protest that an interview is much more than talk; it includes "the notion of negotiated glimpses (views) between speakers", it is about the inter-subjective construction of truth (Kouritzin, Piquemal and Norman 2009:77). Every interview began with an overview of the interviewee's letter of consent which outlined the goals of my research project, and was guided by the list of questions that had been vetted by Carleton University's Research Ethics Board ${ }^{34}$ but it was quickly clear as each exchange began that the glimpse of Shawville we would negotiate would be from a unique perspective. Each interviewee's location within the community (his or her role, relationships, and age group) came through in both the perspectives expressed and the topics most readily addressed.

Despite digressions, the core of each interview spoke to my prepared questions: 'Shawville?' How is it? Where is 'here'? What holds it together? What keeps you here? What has changed? Most of the interviews ended with several suggestions for other people I should talk to, invariably people my interviewee felt would be better placed to give me a glimpse of what it meant to be "from Shawville". I was often referred to someone with "better" genealogical credentials. $^{35}$

At first I looked for answers to the question "What sustains this community?" by asking how it had both navigated and accommodated what I imagined to have been destabilizing events. I believed that examining the concrete and symbolic resources (the tools) available to the community, and the ways in which those resources had been deployed (the strategies the community made use of) to mitigate the impact of destabilizing events would allow me

34 Samples of both the letrer of consent and the interview questions are in the appendix.

35 The ethics approval process asked me to address the question of "exclusions" - how would I respond to people who invited me to meet with groups or individuals beyond those I had already named. My answer was that I would have to weigh what the project might gain in scope against the constraints of time and manageability. Each offer of information or invitation would warrant individual consideration and a respectful reply. As it turned out there were several such helpful offers/invitations and I was able to accept them all without feeling overwhelmed. 
to discern the scaffolding that held the community together. My initial questions focused on events based on the assumption that specific incidents associated with change would be easier to talk about than the more nebulous process of adaptation and change. I had in mind events like the closing of the Hilton Mine in 1977, the separatist referenda in 1980 and 1995, or the 'mad cow' (BSE) scare in the early 2000s (see figure on page 53).

My prepared interview questions were informed by Alessandro Portelli's observation that how an event has been remembered is as significant as that it has been remembered. His claim is that the memory of an event itself "is only a key to everything that happened before and after it... [so that] errors, inventions and myths lead us through and beyond facts to their meanings" (Portelli 1991:1-2). Sarah Green went to the Balkans to study the impact of "shifty" land on the people who lived and moved on its shifting surface. It did not take her long to discover that the geophysical changes she had expected to talk about were so eclipsed by the region's geopolitical changes that they did not, in fact, constitute change in the minds of the people she was talking to. Since they gave "the continual shifting around of the land" no particular significance, they felt that "there was no particular story to tell about it" (Green 2005:28). Green's experience working in the Balkans reinforces the claim that an event is not in itself 'data' separate from the ways in which it has been constituted and interpreted by those who experienced it (2005:14). In her case, as in mine, one of the most interesting discoveries to result from the unexpected answers was that an 'event' is only an 'event' by virtue of the way it has been woven into narrative. If it carries no significance for a particular community it becomes, for them, a non-event.

Like Green, I found that some of my interview questions, based as they were on preconceptions about what 'facts' would be important, were greeted with blank looks or liberally reinterpreted by my interlocutors. I discovered when I began the interviews in Shawville that many of the 


\section{Timeline of significant events in QC history}

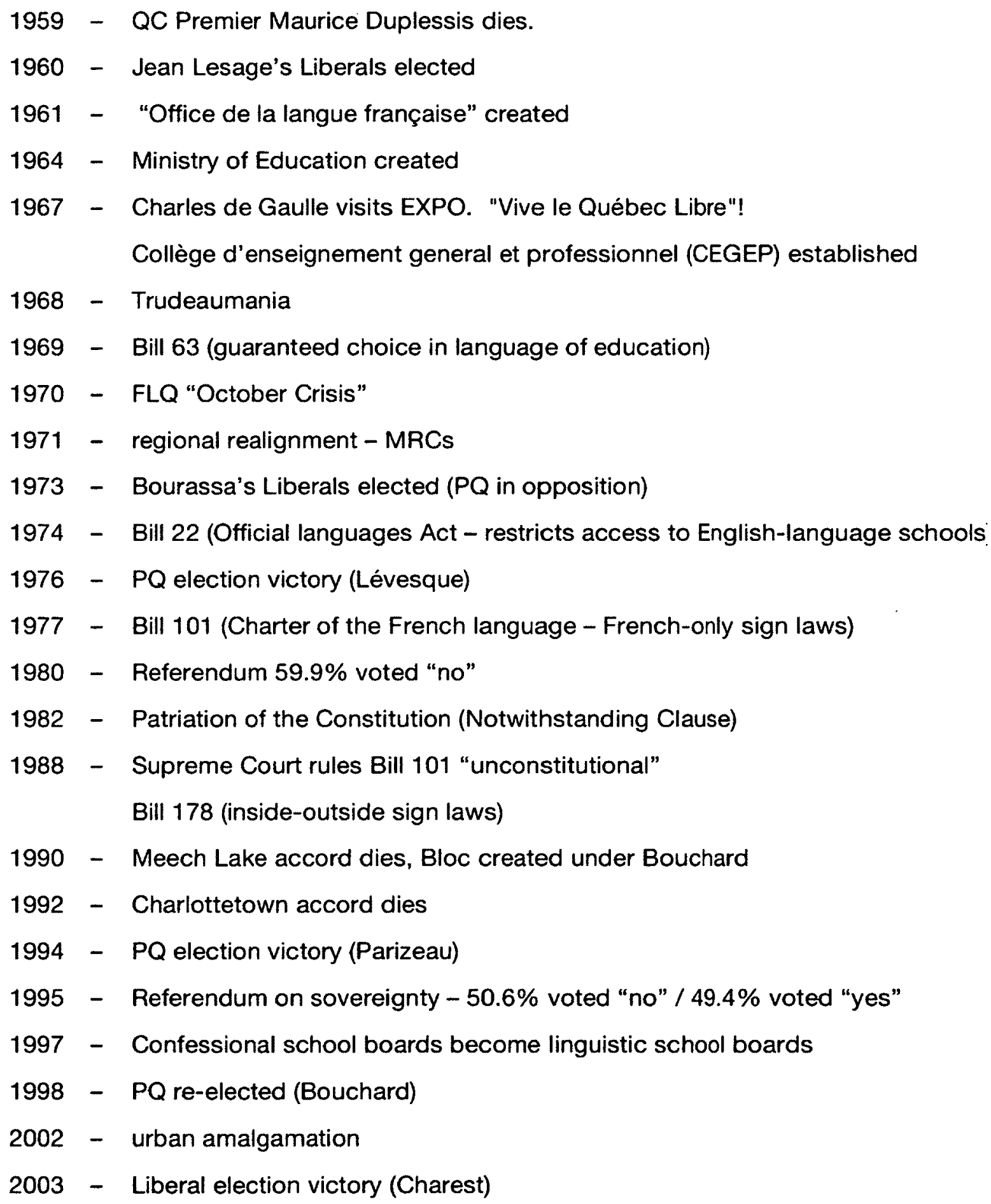


questions I had carefully crafted were meaningless to my interviewees. The shape and direction of those dialogues pointed to 'better' questions. In fact, they reframed the issue I was exploring. Rather than trying to isolate change 'events' and discover how the community had navigated them, my questions began to probe the perceived absence of dramatic change and the shared perception of continuity despite evidence of change.

Green (2005) went to the Balkans to study geophysical transformation and stayed to study the impact of geopolitical shifts instead. The discrepancy between the questions I began with and those that emerged was much less dramatic. The shift from asking how change had been managed to asking what allowed for this perceived 'lack of change' did not fundamentally alter the project. What it did do was focus attention on the important role of perception in the social construction of "reality". It drew my attention to the significance of story and the vital role of meaning-making in motivating and maintaining community resilience.

It was stories that I actually gathered in Shawville, anecdotes about people and happenings, descriptions of life lived in Shawville, tiny cameos of what makes the community 'tick'. Some of the people I interviewed had thought about my questions in the context of their own work or lives and had some analysis of their own to offer. Others offered characters and plots that spoke more obliquely to the 'what' and 'why' and 'how' questions I asked. Stories matter. In her book The Social Life of Stories, Julie Cruikshank writes that stories both provide and depend on "a kind of cultural scaffolding" (1998:27). They provide us with a repertoire of place names, associations, and experiences through which meaning can be negotiated (1998:18). Cruikshank claims that, "the act of storytelling provides one crucial way of engaging directly with the contemporary world" (2005:61). 
People sort out their experiences by talking about them, by exchanging anecdotes, by gossiping. We craft experiences into stories that place them within our cultural scaffolding and make them intelligible, interpreted in light of past experiences, relationships and outcomes. By this description stories serve to facilitate 'meaning-making' in much the same way that particular place/communities serve as Appadurai's "multiplex interpretive sites". Stories, and the shared perceptions and 'cultural scaffolding' they engender, are also implicated in the particularity that supports resilience. Shawville's particularity is both constituted and expressed in the stories that were shared with me.

The centrepiece of my research proposal was a column in The Equity, Shawville's local newspaper, which I envisioned as an interactive data-gathering tool. I was given permission by the paper's owner/editor to write a bi-weekly 'box' for the letters-to-the-editor page. My plan was to share a gem from my archival research or a recent interview in each of my columns and ask for comments and reactions from the paper's readers. ${ }^{36}$ The Equity reaches the majority of Shawville households and many of Shawville's surprisingly extensive diaspora, so I was convinced I had found a way to engage a wide number of people with present and past links to the community. At the suggestion of my committee I also began a "blog" 37 to supplement the more traditional media, and directed my readers to it as a further platform for interaction.

Neither the newspaper nor the 'blog' proved fruitful in the way I had imagined they might. The assumption that written communication would invite participation proved to be, in Michael Agar's words "way off base". The "blog" went nowhere (beyond the solicitous

36 The eight columns which were printed in The Equity are included in the appendix. The initial newspaper entry explained clearly that while every reply would be read, not all replies would be printed in the newspaper. Pieces to be published would be chosen with the help of The Equity staff, according to the newspaper's guidelines re: space, clarity, authorship, etc.

37 www.shawvillestudy.blogspot.com 
comments of a fellow academic with a special interest in marrying history research and social media). The newspaper column received only three replies, and only one of those responses was sent to the paper for publication. The other two were gratefully received as letters sent directly to me. The public forum I had imagined did not take shape. What the newspaper columns did do, however, was an invaluable job of promoting my project in the community at large such that my phone calls to ask for interviews were greeted with few questions and gratifying enthusiasm. I had prepared a telephone script to help me explain the project and found that I rarely needed to refer to it, ${ }^{38}$ pointing instead to my presence in The Equity. I was frequently greeted around town with encouragement, suggestions or stories. It was oral and not written communication that was both more forthcoming and more fruitful.

Interviews, conversations and grocery aisle chats constitute the substance of my research in Shawville. The impressions generated in these varied and informal "inter-subjective" encounters were reinforced by data drawn from the community archives and the local and regional newspapers. As part of my research project I also observed the bi-weekly meetings of Shawville's town council (I attended four meetings over five months), became a member of the Pontiac Historical Society, and attended two Shawville Women's Institute meetings. In the issues raised at these meetings, and the interaction between those in attendance I watched Shawville being "performed" into being (Butler 1988). I noted the features of the performance that Shawville's current leaders and 'meaning makers' experience as significant, and watched the community's formidable collective memory and modus operandi in action.

One thing that became abundantly clear to me long before I began a thematic analysis of the data was the significance of a collective narrative framing the community's sense of itself, its socio-political location and even its economic situation. The community's shared narrative of

38 Telephone script in appendix 
who it is, and where it 'fits' in the world has greater moral force than the grim prospects for employment opportunities and the community's current circumstances seemed to warrant. The themes that emerged from my collected and collated data confirmed the centrality of Shawville's sense of its own worth and dignity (the community's particularity) to its determined persistence over time. My analysis led me to conclude that Shawville's resilience relies on its particularity as a place/community, particularity which is in turn the source for and the result of the community's need to make-meaning of its past experiences and current situation.

My thematic analysis of the collected data began with the preparation of three 'slides' for consideration under my hypothetical collide-o-scope. The slides represent the three factors I originally posited as playing significant roles in Shawville's resilience: geography, political economy, and socio-linguistic identity ("Englishness"). Having established these three broad categories I then sorted the data from my research, the literature, the interviews and my observation notes by theme under the three headings allowing some facts to cross the line between categories, and others to appear in multiple places because they have multiple contributions to make. There are several themes that weave through all three 'slides'. Family, for example, was a significant theme in every interview and spoke to geography (making "place" a question of relationship across space), political economy (speaking to making a living as a collective endeavour), and identity (identifying the deep roots and resonances of belonging). Other themes that surfaced were the community's "distinctness", its experienced isolation (political, social and physical) within the province of Québec, the importance of the Ottawa Valley, language, (un)employment, and the value of "home". The broad themes that emerged from my analysis, their more specific strands, and their implications within the fabric of being Shawville support the claim that Shawville's resilience is a product of its particularity, rooted in the narrative that makes the experience of being Shawville meaningful. 


\section{Doing Research in your own 'Back Yard'}

There has been a great deal written about the potential dangers and the possible benefits of doing research close to home (in both the literal and figurative senses). There are some obvious tensions that raise questions. Is it possible as an 'insider' to achieve sufficient distance from local perceptions? Is it possible as an 'oursider' to gain access to and context for 'insider' understandings? What motivates insider research? Does it risk becoming self-absorbed? What motivates a researcher to study something altogether foreign? Does such research risk recreating "otherness"?

There are those who argue that we cannot hope to understand anything that lies beyond our own experience because it is simply not accessible to us. Davies responds to this objection by reminding us that since "the self is continually under construction" it is possible to "transform the ethnographer's me" such that "other's selves and societies" become accessible (Davies 2008:26). It seems to me that whether research is undertaken close to home (within known cognitive territory) or halfway around the world (in unknown space), the principal task of the researcher is to relinquish the boundaries of 'self' and become vulnerable to new experiences.

Studying "one's own" adds a further layer of vulnerability. The sense of self being challenged is a collective identity shared by familiar others. It is not only the researcher's individual assumptions under scrutiny, but the perceptions and common sense of his or her community as well (precisely the 'ground' of meaning-making that I have insisted is essential to our wellbeing). Robert Labaree cautions that "going observationalist" (the opposite of "going native") complicates the researcher's relationship with his or her erstwhile community or colleagues so that reclaiming his or her old status within the community once the project is over can be difficult (2002:116). Bruce Moore goes further, grieving that in his experience studying 
"his own" became like "tasting the forbidden apple" (2007:28) and resulted in his departure from "Eden", feeling "naked" and "isolated". Stepping out of your "self" to sample your own prejudices and assumptions, he points out, is a risky thing to do. Moore admits to having "seriously underestimated... the impact that acquiring new insights and understandings might have on [his] relationships both at work and with [his] family". He reports, "I did not anticipate the extent to which I would upset the equilibrium that I had established in my life by taking on research responsibilities or that in particular these would require me to question and reassess my appreciation of and contentment with my privileged position" (Moore 2007:34).

As well as questions about the impact of "insider research" on the researcher and his or her subject community, there are also doubts about the insider's ability to gain sufficient distance from the research subject. Labaree points out that while "being an insider offers a distinct advantage in terms of accessing and understanding the culture" (2002:97), "pre-constructed assumptions" are difficult to think past (2002:107), and familiarity "obscures the importance of the mundane" (Labaree 2002:108). Jodie Taylor, who explores the complexity of doing research among intimate friends points to "the difficulty of extracting shared knowledges and implied knowings" (2011:5) when the interviewee reasonably assumes that the interviewer has already heard it all. "Where the researcher-self is part of the Other's narrative," Taylor observes, "the narrative of the researched and the researcher become entwined" (2011:9). It becomes difficult to distinguish between insider knowing and researcher analysis.

With Labaree, I argue that insider/outsider need not be experienced as dichotomous. He describes it as a process, a both/and rather than an either/or location (2002:117). In my own experience I am rarely entirely one or the other. In terms of my research in Shawville, there are contexts in which I am "insider enough" (Labaree 2002:104) to have access to key players 
and form some questions and connections that proved useful. I am familiar enough among the faces in the supermarket line-up, or my family doctor's waiting room to be unremarkable, providing me with the opportunity to practice what Joan Burke calls "privileged eavesdropping", "unobtrusively just being around" while people are talking to each other (1989:224). I am also sufficiently an 'outsider' to continue to stumble across what Michael Agar calls "rich points" (1996:31), moments that allowed me to discover assumptions I didn't know I had made and encounter assumptions I had never considered (1996: 33-34). I have been spared Moore's deep soul-searching, beyond the inevitable growing pains of learning, because as a partial outsider my own identity is not as implicated in my project as Moore's was in his insider research.

My challenge as neither insider nor outsider involved, as all learning involves, stepping outside of myself far enough to distance my own expectations and assumptions. I am not 'from' Shawville by any of the metrics my interviewees used to measure their own belonging. My husband and I moved into the area as adults and although our children went to school in Shawville, we have no extended family in the village to locate us within the community. I have lived in other parts of Canada and in other parts of the world, and count myself among the "hydroponic diaspora" (Neelin 2007) of the old British Commonwealth, rooted in a worldview rather than in any one place (participating in a cultural scaffolding seated in a body of literature - in which the shared repertoire of place names, associations and experiences is drawn extensively from a shared tradition of stories).

That said, I have come to love this place and my neighbours. It is from a place of distance and fondness that I feel able to address this work. Acknowledging that my choice of research topic grew directly from my relationship with this community confirms Davies' observation that the researcher is present in all stages of the project, from the choice of topic, through the 
process of field work and research, to the writing and the final 'product'. The degree of selfconscious reflection entailed rendered research a humbling experience.

Engaged in deliberately distancing myself from a familiar community in order to see it afresh (to render the familiar strange in a Bakhtinian sense) I kept in mind an experience I had some years ago at a workshop preparing volunteers to go overseas. My husband and I (and our four children) were on our way to Ecuador. At one point, while the group was discussing the challenges of learning a new language, one of the other workshop participants exclaimed glibly that she "already had that covered". Where she was going, she would be able "to hit the ground running" and be "immediately useful". Deep in our own fears of finding ourselves mired in obstacles and useless, we were all impressed. Not the workshop leader; he was quick with his warning that without the enforced 'infancy' of several months without words there was a very real danger of doing harm. He assured us that it would take as long to recognize local categories of thought and patterns of interaction as to learn the local language. It would serve us well to watch for a while. Words alone would not tell us what counted as a problem or a solution. It would take time to understand the social context and figure out what questions needed asking.

Did I ask the "right" questions in this research project? I can only make a case for the questions I raised on the grounds that they grew out of the work as it progressed, and proved fruitful in uncovering some interesting information. Had I set out with a different goal, I would have formed different questions. There is no way to know if there is something altogether different that begs to be asked except by probing about with fuzzy questions, blunt instruments, imagination and patience. Appadurai pithily observes that the varied and overlapping layers of modern experience are infinitely 'nested' so that wherever we choose to begin, whatever heuristic point we adopt, "the last turtle is always a matter of methodological 
convenience or stamina" (1996:11). It seems inevitable that the same limits to stamina and constraints of time are at work in where we end an inquiry. It is important to remember that what we 'know' is always contingent, fluid, and contestable.

\section{Conclusions}

The goal of my observations, interviews and archival reading in Shawville was to answer the question, "What accounts for this community's resilience?" I aligned a close study of Shawville's immediate situation with a sense of its more distant context in order to assess the breadth and depth of the ground under the community's feet. I considered it important to keep Shawville's context in view, and look for connections to events unfolding at the provincial, national, and larger scales. I counted on the poly-focal (multi-disciplinary) collide-o-scope lens I employed to correct for both myopia and presbyopia, making it possible to see simultaneously both distant happenings and what was directly in front of my

nose. I relied on the spaces between disciplinary perspectives to allow my focus to move, and the contests between those perspectives to create movement.

In the pages that follow, my impressions, the words of those I encountered, and the words of the theorists I consulted are woven together as needed to tell a story, make a connection, or illustrate a point. Ideas are sorted into groups according to their content rather than their source, such that an interviewee's observation might be backed up by a scholar's findings, or a researcher's theory supported by an interviewee's anecdote. This "interweaving" of theory, research activity and evidence responds to Davies' challenge to make the steps in my analysis, my own train of thought, visible to the reader. She argues that such transparency is necessary to validate the findings of qualitative research $(2008: 269)$. 
The next three chapters assemble the relevant scholarly literature together with the interview data and my own observations into three 'slides' for examination under the collide-o-scope lens. The categories broadly represent the three factors I believe have played significant roles in shaping and sustaining the community of Shawville: its geography, its political economy, and its socio-linguistic identity (its "Englishness"). We will consider each factor in turn, focusing on its contribution to Shawville's particularity, and thus on its part in supporting the community's resilience. In chapter three, we begin by examining the role of its geography in shaping Shawville's identity and supporting the community's resilience. 


\section{Chapter Three: Geography - Place, Space and Location}

\section{Introduction}

This Chapter focuses on Shawville's geography, collecting in the collide-o-scope slide the mix of experience, perception, history and politics that have, together, placed Shawville in space. As the pages that follow will show, Shawville's interpretation of where 'here' is, is more significant to the community's resilience than its actual place in space. Being inside but outside Québec (politically), and outside but inside the Ottawa Valley (in terms of history and relationships), the community inhabits contested, ambiguous space. Choosing to stress its meaning-rich location within the Ottawa Valley over its more ambivalent place inside Québec is a practical choice. Through it, the community mobilizes its best case for particularity and reinforces its resilience.

The interviews I collected in Shawville are replete with stories, some well-rehearsed and often recounted, some barely more than gossip. The "purposeful sample" of individuals I listened to were all, in their own way, quite comfortable with the particular vocabulary and cadence of 'being' Shawville, a place and identity that obviously shaped what they had to say. In the text that follows I have left many of the anecdotes intact. In others the imperatives of brevity and legibility led me to paraphrase the speaker and 'tidy up' the repetitions of verbatim transcription. I add clarification where needed. My objective in presenting the stories as stories where possible is to highlight the role of narrative in mediating experience and the significance of this mediation through narrative (i.e. this act of meaning-making) in supporting community resilience. 
Each of the Shawville interviews began with a variation on the question, "Where is Here?" The stories about 'here' that were shared with me in Shawville peopled the Ottawa Valley with genealogical charts and described the comings and goings of trade, migration, and intermarriage. My interviewees emphasized the community's particularity and uniqueness as an English-speaking community in Québec. They referred to its self-contained independence (Gordon), "self-conscious oddness" (Elaine), "tightness" (Dan), "continuity" (Robert), and "distinctiveness" (all). The majority of the answers I was offered focused on a 'storied' connection between the people, the valley and the river that were rendered in anecdotes and character sketches.

The distinctive features of Shawville's geography assembled in the slide under our hypothetical collide-o-scope lens corroborate the claim that Shawville's location, inside and outside Québec, outside and inside the Ottawa Valley, has been and remains significant to shaping and supporting the community's particularity. The buttons and threads of data the slide draws together address the questions, "How has being 'here' (both a physical and a psycho-social place) shaped Shawville's particularity?" and "How has that particularity contributed to the community's resilience over time and through change?"

\section{Where is Here?}

Scholars claim that all Canadian storytelling begins with the question, "Where is here?" (Frye 1971). ${ }^{39}$ They contend that Canada's geography, specifically its over-abundance of space, demands a deliberate act of meaning-making. Frye suggests that this obsession with story-

39 Although there are clearly more recent scholars who pick up on Frye's theme (and I will draw a number of them into this discussion) I feel a particular connection with the 'canon' of Canadianist literature that was my first introduction to many of the ideas I will develop. I am disinclined to look for holes in a prior argument, preferring to look instead for toe holds and traction. Frye, Innis, Careless and their ilk are familiar tools 'to think with' and have therefore made their way deep into my analytic framework. 
telling (meaning-making) is part of the process of inhabiting a place, of appropriating it and making it our own. He argues that the "consolidated chunk of experience, reflection and sensibility" that confronted Canada's embryonic writers required "a plot to put this material in causal shape" (Frye 1971:232). Expressed in other words, experience needed context and vocabulary to give it meaning. Frye's posited writer felt compelled to articulate this "chunk" of sensation as a story to make it "sensible".

The first Europeans to settle on the Québec shore of the Ottawa Valley shared this imperative to make sense of their surroundings. "[É]garé dans une nature qui avale la civilisation... il fallait bien meubler ce grande vide " ["[L]ost in a landscape that swallows civilization... [they were] driven to furnish the vast emptiness" with stories (Frigon 2007:xxi translation mine)]. Our instinct as homo narrans is to people a void with events, characters and familiarity. We, and the world we inhabit as people, rely on meaning. We are made of story. As Thomas King (2003) expresses it, "the truth about stories is that's what we are". Articulating 'where' we are through story is part of weaving our own place out of space, constructing and marking our particulariry. The story woven together in this collide-o-scope slide describes the physical and symbolic consequences of Shawville's particular place and its significance as part of the scaffolding that supports Shawville's resilience.

\section{Placing Shawville in Space}

Shawville is seventy-five kilometres west of Ottawa/Gatineau (Canada's National Capital Region) on the north shore of the Ottawa River. The town sits between the relatively fertile lowlands of the river bed and the thin soil of the Canadian Shield, tucked between the river which constitutes the Ontario border and the Gatineau hills which separate the region from the rest of Québec. 
In terms of both geology and history the Pontiac shares much with Gatineau County on its eastern border. Helen Parson's 1977 study of that county provides a helpful description of the region that serves to locate this part of Québec. Both counties, for example, are predominantly Shield territory, described by the Canada Land Survey as having "limited arable soil" (1977:23). They lie together in a triangle of land defined by the Ottawa River to the south and west, and the Gatineau River to the east (see map on page 75).

Parson (1977) divides the development of the region into three historical periods and describes them in broad brushstrokes that are equally true for Gatineau and Pontiac Counties. From 1800 to 1850 lumber was the region's economic driver. In fact, according to Forbes Hirsch of the Historical Society of Ottawa, timber and other raw wood products reached eighty per cent of all exports leaving Upper and Lower Canada in 1838, and seventy per cent of the timber harvested in the Canadas in 1849 when eighteen point two million cubic feet "came down the Ottawa". As Hirsch wryly observes, it is hard from this vantage point to "appreciate the then relative importance of this early 'valley' industry" (Hirsch 1985:3). Even agriculture was subordinate to the lumber industry. John Gourlay writes that, "clearings were enlarged and crops were raised, hay, oats, pork and flour, with the lumber market in view" (1896:141). The market for farm products assured by the hungry timber shanties "stimulat[ed] high prices and agricultural prosperity in the Ottawa Valley" (Elliott 2004:241). Elliott's claim holds equally true for agriculture on both the South and North shores of the Ottawa River.

Between 1850 and 1918 the character of the timber trade changed. It became both bigger in scope and better organized. The largely Irish immigrants who first worked the shanties and farmed the remote region (Parson 1977:24) were joined by French-Canadians who moved into the area to work in the expanding industry. The French Canadians were encouraged 
(and given some incentive) to leave the over-crowded St. Lawrence Lowlands and re-settle in the Gatineau and Upper Ottawa Valleys by colonization societies and government policy (both provincial and federal).

Another wave of change came with the construction of the railroad up the Gatineau River to Maniwaki. Gourlay grieves the loss of small hamlets with the closure of smithies, hotels and public houses along the cart road. The construction of the Pontiac Pacific Junction Railway through Pontiac County carried similar consequences, changing not only the look of the landscape, but the sounds and smells of human settlements as well (Gourlay 1896:197).

The landscape itself can be conceptualized as a palimpsest (Osborne 2001:8) where changing uses of and ideas about space and place are written over each other, layered onto the earth such that they 'naturalize' the socio-cultural construct of the moment. Even a superficial look at the 'natural' landscape of the Ottawa Valley illustrates this idea. Archaeological evidence on Allumette Island speaks of the River as a transportation artery in the continental copper trade 5000 (or even 8,000) years ago (Graham 1994:2), a story 'written over' when the river became important as a thoroughfare in the fur trade, connecting Montréal to the Great Lakes. An early explorer, one Alexander Henry, recorded an encounter with Algonquin traders in 1761. He writes, “... while paddling against the gentle current of the Lake des Chats, we met several canoes of Indians (Algonquins) returning, from their winter's hunt, to their village, at the Lake des Deux Montagnes. I purchased some of their maple sugar and beaver-skins in exchange for provisions" (Hirsch 1985:1). Frigon grieves that when the Algonquin people's mighty river was named for the Outaouais who succeeded them in the fur trade (2007:xxix) the Algonquin who initially inhabited the region became " un peuple effacé de dessus de la terre " ["a people erased from the face of the earth" (Frigon 2007:lix)]. Roger Blanchette (2009) also records the 
"disappearance" of the Algonquin from the region; first weakened by disease carried to them by their French allies, then decimated by the Iroquois armed with English guns, and finally collected by the Oblates into their mission at Lake des Deux Montagnes (2009:32). The Ottawas or Outaouais who " n'ont jamais vécu dans la region qui porte leur nom " ["never lived in the region that carries their name"] were encouraged by the French furtraders to fill the void left by the Algonquin (Blanchette 2009:34 translation mine).

Later, and for nearly a hundred years, the river served as a conduit for logs. Its cycles of freeze-up and thaw understood in the context of getting access to the forests, and making the most of the powerful spring rush of water to move huge rafts of timber. As settlement followed lumbering up the valley it made use of the newly cleared access roads to take possession of the newly cleared land. Place was again re-written into space. Appadurai suggests that just as "spatial locality" is inscribed into bodies through various material signs from names and rituals to clothing and food, place is inscribed into space by means of roads, fences, and buildings (1996:179). Gourlay boasts that the earliest settlers in the Pontiac "had to remove boulders for fences and drains, and level hills and fill hollows, to make the lands the beautiful level fields that almost smile in your eyes as you pass them" (1896:61). The level fields and fences tell us as much about the farmers' sense of themselves and their expectations of 'home' space, as they do about the practical considerations of farming.

The earliest European arrivals to the Ottawa Valley did not recognize that the space they entered was already richly inscribed as place by prior harvesters and inhabitants. By his own admission, Gourlay could "see nothing but swamps, hear nothing but frogs, and feel nothing but mosquitoes" (Gourlay 1896:4). He is scathing about the failure of earlier inhabitants of the region to 'write' themselves into the space in such a way that he could 
'read' their presence. Gourlay claims he has "not heard of a single trace of the march of Samuel Champlain with his army of Frenchmen with their Indian allies", while his people, "British, with a good sprinkling of U.E.L. [United Empire Loyalist] Americans" have, in the relatively short time since their arrival, "taken up the whole valley" (1896:4). Indeed, when Philemon Wright and his party arrived on the site that would become the city of Gatineau (across the river from what was then Bytown now Ottawa) they set to work clearing trees and building sheds and houses, inscribing the space as their own (Patterson 1989:22). In Gourlay's mind "it was natural [for Wright and his party] to picture to themselves a city covering all these banks, with factories of every kind... " (1986:8). ${ }^{40}$ Wright, prescient as he was, could not have anticipated "the emergence of the National Capital of Canada at the precise place he had chosen" (Laberge 1989:4). As Laberge observes, Wright's "instincts told him" that the area held a promising wealth of resources. The confluence of economic, political and social factors that would play out in the region was unforeseeable.

The ideas about the appropriate appropriation of land that Gourlay's comments reflect are part of a world view in which owning property equals being civilized. The equation carries such ideological weight that an "inappropriate" (i.e. non-appropriating) relationship with land "renders one indistinguishable from it as a natural resource waiting to be put to proper use" (Sullivan 2006:122). To qualify as fully human within this world-view a society must appropriate and transform property. Changing ideas about what constitutes the "proper" use of land is part of the array of changes confronting agricultural communities like Shawville.

40 Gourlay also relates that "[ $\mathrm{t}]$ he sounds of the axe and the falling of trees brought the Indians from their sugar making" to see what was going on. Initially "friendly visits... receiving presents and returning others of sugar and venison" became a less friendly meeting with a Hudson Bay Company called in to act as interpreter so that the "chiefs" could demand of Wright "the reason of these innovations, cutting their woods and possessing the lands" when it became clear the new comers were staying (1896:166). It is especially significant that Gourlay reports: "They [the Indians] held that the lands were as merchantable as the sugar, but he [Wright] denied their rights to lands as wandering tribes" (1896:167). 
While agriculture was at one time sufficient (even laudable) as an appropriate use of land, it does not yield enough profit, quickly enough, to satisfy more 'modern' models of appropriate land development. I re-engage this discussion in Chapter Four.

\section{Home Space}

Henri Lefebvre (1991) claims that social space is a deliberately fashioned social product. It is spun, as it were, in the tracks of human activity and mobility (1991:87). He suggests that we actively form places to serve specific functions and "appropriate" spaces by making them "proper to" their symbolic and/or practical use (1991:84). They become 'our' spaces as they fill up with the artefacts of our lives, our stories and memories, our noise and silences, our comings and goings. The idea of space as a social "product" helpfully situates Shawville both geographically and socio-psychologically. Shawville's 'location' is a web of relationships that include the English-language shops, services and institutions available across the Ottawa River in the Ontario towns of Arnprior, Renfrew, and Pembroke. Tellingly, among the people I interviewed, those who reported travelling to "the city" for entertainment or shopping invariably meant Ottawa. Their conceptualization of space and place jumped over the City of Gatineau, and often excluded even the more Anglophone community of Aylmer (incorporated into the amalgamated city of Gatineau in 2002) to draw Ottawa into the travelled web of known space. Robert, a geographer and retired farmer articulated the boundaries of his sense of home very clearly:

[F]or us it's always been home, and well, I mean going back many generations, on just about every side of my family. They came from Europe; they came from England to Shawville, and extended the community up to Thorne. To me it's all part of 'Home'. From my family, going back to my great grandparents, we've absorbed all the anecdotes about life in the community going back to the original settlers. The same could be said about any of the local residents around here. We're a bit of an anomaly 
in this part of Québec. ${ }^{41}$ The rest of Québec, for the most part they don't even know we exist. Our eyes turn that way [toward the Ottawa River and Ontario]. We're part of a valley. To the north once you get past the hills there's not much between here and the North Pole. Westward; Sheenboro. There's no roads. It ends there. And past Ottawa, yeesh, that's not our, not our land.

(Robert)

Lefebvre insists that place is not space that has been "socialized" from some "wild" presocial state. There is, he argues, no such thing as "wild" space (1991:190). In making this argument he points to the prior existence of social expectations and interpretations that colour what we see so that we never perceive a simple tree, but always a tree filtered through socially constructed ideas about tree-ness. His position makes it impossible to naturalize any given configuration of space by denying the possibility of 'natural space' altogether. Taken at face value Lefebvre's claim seems to push the arrogance of terra nullius to a new limit, but I believe he is making a very different point. I read in his argument not the insistence that rocks have no existence qua rocks, but that we have no access to them except as social constructions. We are, in fact, so limited in our engagement with space outside our own constructions (outside our storied world) that, like Gourlay, we are unable to 'see' the socialized space of people who "write" space differently.

Lefebvre's ideas about the social production of space help us to remember that the trees, the farmland and even the mighty Ottawa River have been assigned meaning by human agency and placed in space by a mix of deliberate actions and accidents. Wright's act of 'terraforming' constitutes only one of many ways in which we form the land to our uses. As Lefebvre anticipates, the production and re-production of space over time can be

41 I have spelt Québec and Montréal with the accent aigu throughout this document. Having acquiesced to the requirement for consistency I feel it is important to acknowledge that the presence or absence of the accent is a matter of politics rather than orthography. The words have legitimate French and English spellings. I believe it would have been more appropriate to omit the accents when citing the (English) words of my interviewees. 
traced. Space has history (Lefebvre 1991:116). Maps of the area have been reimagined, and Shawville's relative location has been reinterpreted to reflect the changing requirements of each new socio-economic agenda.

The following story, told to me by Venetia, the local storyteller/archivist/historian I interviewed, relates how Pontiac Village (a local site now known mostly in memory) lost its chance to be Canada's capital city. The story reminds the listener of the region's past glory as a major economic player. It also speaks to the coincidences of policy and timing that contribute to placing space.

The Ottawa River has always been the trading route. Forever. From the beginning of time. It was for furs at first and they had trouble with the Iroquois. The Iroquois and the voyageurs used to have battles. This was at Mondion's Point where there was a Hudson's Bay post (and it was Northwest Company at one time) and so they were trading furs there. The Indians have been there for a long, long time. Then the lumbering industry took over. Well the Prince (you've read about that) Prince Edward and Prince Arthur stopped there. This was the lumbering industry and well then there's the canal (you see there's the Chats Falls there... ) near where Pontiac Village is. They tried to build a canal through there but because of government mismanagement they failed. But before they gave up they had built a railroad around the falls from Pontiac Village to Union Village and that was the third railroad in Canada. The first one was around the Lachine Rapids, the second was around Niagara Falls and this one was around the Chats Falls. If that had opened up they could have opened up the Ottawa River and they could probably have opened up (well, if they hadn't made the dam at Bryson they could have opened it up there) and had the traffic go right on up and over to Georgian Bay through the French River. And if that had happened, it's a much shorter route to the Great Lakes than through the St. Lawrence Seaway, so, this would have been where people could have stopped, at Pontiac Village, and that's why I think it could have been the capital of Canada. Because why would they stop in Ottawa if they could stop in Pontiac Village? Ottawa's not on the route. They didn't need to stop there. They could have stopped at Pontiac Village. That's why I think it could have been the capital if the government had decided to open it up. There's the story.

(Venetia) 
It is hard to hear Venetia's story granting alternative fortunes to long-forgotten communities along the Ottawa River as anything but apocryphal, but however dubious the story may be as an alternative history it exemplifies beautifully Venetia's sense of her community as central within its own world. Her perception of the region's unique significance participates in a shared certainty of the community's particularity. The story of Pontiac Station's changing fortunes illustrates clearly the way space is re-organized to reflect each new "logic-ofdevelopment" and the changing values it assigns to space (Clement 1997:251).

Acknowledging that Shawville's place in space is as much the product of socio-historical coincidence as it is a physical given allows us to recognize the imperative of "meaningmaking" at work in reinterpreting Shawville's location. Through story (the constitution and imposition of meaning) the community strategically (re)places itself in order to enhance its particularity and support its resilience.

\section{Contested Space}

Shawville is situated in Pontiac Regional County Municipality (Pontiac MRC - Municipalité régionale de comté). The region, known familiarly as 'the Pontiac' claims for itself a collective identity and history. As the map on page 75 shows, the region's borders remain contested. The MRC de Pontiac of Québec's administrative map (the solid outline) does not match Pontiac County's lived space (the dotted line). This distinction between political space and experienced space is significant, both as a symptom of the on-going contest over how the Pontiac will be defined, and as an illustration of the potential differences between place as an administrated jurisdiction and place as a vessel for meaning. At the micro level, in the collective imagination of "Pontiackers", 'the Pontiac' means "the old county of Pontiac which included all the area of the present Regional Municipal County sic (MRC) and the townships 


\section{MRC Pontiac}

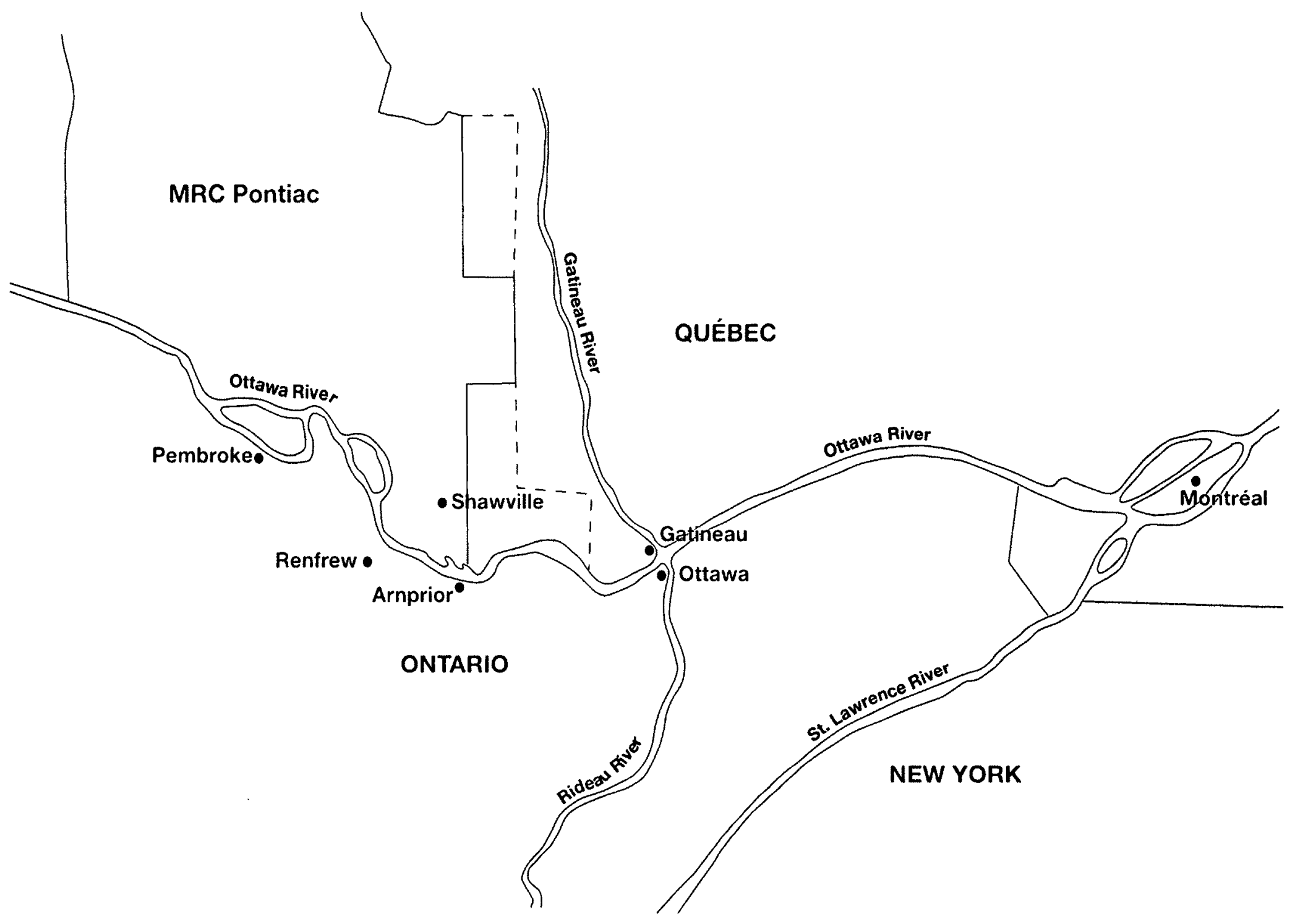


of Onslow... and Aldfield which historically, economically, and culturally have always been part of "the Pontiac" (Graham 2000:5).

[T] he district has political boundaries, but as a community it often spills over those boundaries. In many ways it is a region unto itself, perhaps best illustrated in the appellation 'the Pontiac'. In the minds of many it has become more than just a county. It is a place that defines who they are as a community.

(Graham 1994:7)

The Pontiac, by its use of the definite article, declares itself at once unique and known, not a generic example of place, but this particular place. ${ }^{42}$ Significantly, Graham is sometimes referring to a place, and sometimes to a people. "The Pontiac" conflates people and place. The inter-articulation of experience and location plays a part in shaping the community's particularity.

At the macro level the region is caught up in a much bigger struggle over where "here" is, and how it should be named. A key feature of Shawville's amplified precarity is its location in what could be called "a linguistic contact zone" ${ }^{33}$ It sits on the border between French and English Canada, between the geographies of sovereigntist and federalist agendas. In his writing about geopolitics, Gearóid Ó Tuathail (Gerald O’Toole) describes geography as "a product of histories of struggle... over the power to organize, occupy, and administer space" (1996:1). O Tuathail likens the making of maps to "the seizure and disciplining of space" and calls attention to the ways in which place names and territorial boundaries reflect "a power struggle between different societies over the right to speak sovereignty about geography, space, and territory" (1996:11). He insists that geography is the result of human agency and

42 In other contexts, notably Canada's Yukon, use of the article has been rejected as pejorative, understood to mark an externally governed territory, a resource base for others elsewhere rather than a self-defined place. In the Pontiac the definite article is employed as a definite statement of particularity.

43 Dr. Paul Litt. In-class communication. Carleton University. April 2008. 
contest. Geo-graphing (earth writing) deliberately inscribes connections and separations, names and borders, into the earth.

The struggle over speaking space (rephrasing Ó Tuathail to reflect a slightly different emphasis) has two faces in Shawville. It is a symbolic battle over the right to "speak space" (to name and claim the space for a particular political entity and agenda), and a practical contest over space in which to speak (a struggle over language use and language "rights"). Marc Levine illustrates a similar struggle over speaking space in what he calls "the reconquest of Montréal" (1990). He identifies Québec's Charte de la langue française (French Language Charter) as "the legal and symbolic cornerstone of the Francophone reconquest," claiming that the exigencies of the new language law physically inscribed the regime change into the landscape (1990:119). French-language signs mandated by Bill 101 (the PQ's Language Charter) in Levine's words, “restored” Montréal's "French face" (Levine 1990:114). They re-claimed the space both symbolically and practically. In Shawville and through the Pontiac, signs on businesses, roads and the highway are an on-going point of friction. The replacement of English names with French ones has effectively replaced space, changing the location and allegiance of places in relation to their past and present socio-political and linguistic surroundings. Amalgamations like the one that subsumed Aldfield, Wakefield and Masham into Lapêche or made Eardley and Onslow disappear into the confusingly-named Pontiac Municipality in the neighbouring MRC des Collines wrote a new layer onto the landscape palimpsest. The English-speaking communities of the Pontiac feel erased (along with their spaces and historic claim to belonging) by the process. ${ }^{44}$

Changing the name of towns, changing the name of streets, lakes, rivers, all that is is to try and change the nature of a community, change the history. It's very hard for

44 Clearly, the process of erasure and re-inscription did noc begin here. The appropriation, misallocarion, mispronunciation, and outright erasure of indigenous place names (to wit Pontiac) and the displacement of indigenous spaces highlight the very real impacts of writing over space. 
Québec separatists to argue that Québec has always been French if the evidence tells them otherwise. But if they can make everybody including google earth and google maps buy into the idea that everything's chemin de la Rivière as opposed to River Road - when the English people start buying into that we're throwing in the towel on our own history... It's deliberate right, when you start to change the name of things... make us change all the signs, make us disappear as a community.

(Gordon)

Pontiac is still the second poorest Municipality, sorry MRC, in Québec. Of course that's one of the changes, terminology, the names of places... but I don't think those things are - maybe they're significant in Québec City, but nobody here would call [the hospital] the 'CSSS whatever de Pontiac', they'd say, "I'm going to Shawville Hospital" and everybody would know what they're talking about.

(Heather)

I don't think I was ever to Gatineau proper, and I'll be dead in the cold cold ground before I call Aylmer or Hull Gatineau. It's not part of my consciousness at all.

(Gordon)

I draw attention to this contest over place names because it is a significant feature of Shawville's reality. Indeed the existence of language as a contentious issue is so fundamental to Shawville's particularity that it cannot be excluded from or glossed over in a study of Shawville's resilience. That said, I will repeat here that I am not interested in entering into Québec's sovereignty contest per se. Québécois nationalism is pertinent in this discussion only because of its impact on this particular community and its resilience. Shawville's location in disputed/disputable space has given the community unusually self-conscious flexibility in defining where "here" is for itself and on its own terms. It has also forced the community to be intentional and selfconscious in so doing. I contend that Shawville exploits its location in disputed space to its advantage. It uses the opportunity to define its own place to put itself in the best position to support its particularity and enhance its resilience as a community. Insisting on its inclusion in the Ottawa Valley, and emphasising its distance from Québec's centres of power in Montréal and Québec City is a valuable strategy in enhancing Shawville's particularity. 
Before the stirrings of Québec separatism and the 'Quiet Revolution' of the 1960s, being in the province of Québec had no particular meaning for, or impact on, the lives of Shawville's residents. Even the "October Crisis" of 1970 was little more than distant rumbling, according to the Shawville residents I spoke to. Arguably, the community's location inside Québec became relevant for Shawville only with the 1976 election of the Parti Québécois (PQ) when Québec's provincial boundaries took on new significance. With the PQ victory Canadienfrançais became Québécois and the ethnic identification of a people within Canada became the political identification of a distinct space separate from Canada (Clement 1997:266). Shawville found itself on the 'wrong' side of a border with new salience and weight. The area remains rural and majority English-speaking in what has become an urban-focused and francophone-dominated political environment. The social and geographic distance between Shawville village and Québec City (the Capitale nationale du Québec) is vast, allowing Shawville to feel invisible to and excluded by any sense of province-based identity.

The following interview excerpts expose the feelings of resentment, betrayal and frustration that complicate the relationship between my interviewees and their location in Québec.

The CSST (Worker Health and Safety Commission) refuses to speak in English. ${ }^{45}$ It's just an irritation. It's not as if we're going to convert. It felt like we were being treated in a racist way. This is our culture. It doesn't make us any better at French [to force the issue] just more frustrated... five or six generations is a lot of culture... If it came down to separation I'd jump on [the opportunity to join Ontario].

$$
\text { (Jared - young father and farmer) }
$$

45 According to statistics published by le ministère de l'Agriculture, des Pêcheries et de l'Alimentation du Québec (MAPAQ) in 2008, the MRC Pontiac covers 1,282,408 hectares of land. 44,182 hectares are occupied by farms. 28,859 hectares within those farms are under cultivation. As of January 2008 there were 278 "farming enterprises" in MRC Pontiac registered with MAPAQ. 12\% of those farmers indicated French as their preferred language of correspondence. $88 \%$ registered themselves as English-speaking (MAPAQ 2008). Local representatives of all the various government agencies and programmes find themselves mediating between a French-speaking bureaucracy and an English-speaking population. 
We don't think of ourselves as Quebeckers hardly at all, except when it's foisted upon us... I can remember clearly saying to a kid on the school bus "if we lose this thing [the 1980 referendum] we're moving to the States". And so I obviously heard that somewhere. To me there must have been - I felt this certainly in ' 95 - a sense of betrayal from the rest of the country - that the rest of the country would allow this to happen to us. 'Cause I've always felt that English Quebeckers are the most passionate Canadians cause we have the most to lose. We have to live being Canadian all the time. So I certainly have felt that sense that the rest of the country doesn't give a crap and the words I hear often if you complain about it is "why don't you move?"

- This is home! "Why don't you move?" You'd never hear it said to a Franco-Ontarian, "Why don't you get out and move to Québec?" But there's that double standard applied to English Quebeckers. Who speaks for English Quebeckers in the rest of the country? They don't even know we're here.

(Gordon - bigh school teacher)

When the PQ came to power, Dad was still working for the department of highways. On the night of the election he drove the grader to the government sheds on the \#148, parked it, and never went back. He refused to work for that government. It was quite a statement, and quite knee-jerk, because he never got a good job again. Where else do you get a job like that? He pumped gas. He worked for the council in Clarendon, brushing in the ditches, busting beaver dams, anything that he could kind of do. That was huge.

(Debra-vice-principal)

At times I've wondered about that, if [living in Québec] bothered me. But now it seems to be pretty low key... A lot of people sold their property when they felt that Québec would separate. My father-in-law for example sold his home, his office building, everything, when he thought Québec was going to separate.

\section{(Dorothy - retired adult educator)}

There was the Villeneuve scare which must have been somewhat after [the 1995 referendum], when the FLQ guy ${ }^{46}$ was coming on the school bus and people were armed because there was going to be like a standoff against him and I remember the police were so scared and they never let him get to Shawville. They detoured him into Quyon. But I think at that point people were starting to take a stand and say "f-you, we're part of Canada and we're staying part of Canada". I know here there was a movement, so to speak, to separate from Québec. If Québec separated, then

46 Raymond Villeneuve was a founding member of the Front de Libération du Québec (FLQ). He served jail time for manslaughter for his part in a bombing in the $1960 \mathrm{~s}$. 
we were going to go next. I think there was some justification for it perhaps. I think we belonged to Upper Canada at one time and... everybody had good reasons, but I think it was more a matter of the heart than any sort of pre-existing conditions that might have been in the BNA act or whatever, but people felt a lot more aligned with the Ontario side than they certainly did with the Québec City side.

(Heather-newspaper publisher)

It is important to hear these declarations for the expressions of impotent frustration that they are, rather than giving them weight they do not merit. The anger Gordon expresses, and Heather's talk of an armed mob, are not borne out in the day-to-day interactions between French- and English-speaking neighbours. The fear conveyed by the words, however, is very real. This community has much to lose if Québec were to secede from Canada. After all, if their location on the Québec side of a provincial boundary is sometimes uncomfortable, finding themselves on the Québec side of an international border threatens to feel precarious indeed. The important theme in these excerpts is the overwhelming sense of exclusion. The speakers feel unwanted, and feeling unwanted they feel afraid. Given this, the impulse to transfer their sense of belonging across the provincial border into Ontario is understandable. Their long-standing relationship with the Ottawa Valley is already replete with the meaning that is essential to Shawville's well-being and continuity as a particular place/community.

\section{Distinct Space}

One of the people who responded to my columns in The Equity was the daughter of Basil Quaile. In 1971, Quaile, then Mayor of Otter Lake, was elected Warden of the County of

Pontiac. What his daughter, Jennifer, offered to tell me was the story of Pontiac County's bid for "special status" within Québec. Jennifer and her father kept a scrapbook of newspaper articles chronicling the events and emotions of the time. Their story is about contesting place, a battle over where "here" is for Shawville and the surrounding Pontiac region. 
In 1970, under Maurice Tessier, the provincial government's Minister for Municipal Affairs, Québec undertook a regional restructuring project. The goal of "régionalisation" was to re-organize Québec's regions into larger Regional County Municipalities that would be better able to afford their newly "downloaded" responsibilities for "assessment, housing, and planning" (The Ottawa Citizen 05/15/1971). The Department of Municipal Affairs invited the twenty-four municipalities of the Pontiac to form "one large municipal community including them all". The municipalities involved had only "to notify the Department of Municipal Affairs of their intention to amalgamate" and a government officer would arrive to help them organize themselves (The Equity 03/24/71:2). A committee of mayors was struck, but no agreement between the Mayors was communicated to Québec City. An editorial in The Equity (03/24/71:2) chastises the committee organized to "think about amalgamation" for failing to put forward a plan.

Minister Tessier's "White Paper" on municipal restructuring was tabled in the National Assembly in March 1971, a year after the first suggestion of amalgamation. Information about what the Paper proposed was initially provided to Pontiac councillors only in French. Months later (only weeks before the deadline) an English translation reached the Pontiac where the planned changes met with fear and surprise. If carried through, the 'White Paper' plan would see the Pontiac divided four ways. Pontiac County Council held a "special" meeting to discuss their response. The Department of Municipal Affairs invited Mayors from across Québec to participate in a Provincial-Municipal Conference in Québec City in order to discuss the White Paper and its proposals. Pontiac's twenty-five Mayors decided to charter a bus and attend the conference as a united delegation. They felt it would be "advantageous for Pontiac County as a whole" to be represented by "100\% of its mayors standing together" (The Equity 05/5/71). 
The initial lack of action and the fearful reaction that came later can be explained in context. A feature article published in May 1971 in the Ottawa Citizen reported "until recently the provincial government's influence in the county was minimal... Pontiac was essentially a sparsely populated, nearly autonomous English-language enclave in Québec". The Citizen's staff writer described both the province's new interest in "meddling" in the region's affairs and its "new insistence on using French" as "irritating". The Pontiac's residents preferred events in Québec City to remain "distant" from and "inevitably insignificant" to them (The Ottawa Citizen 05/15/71). In evidence of this, Quaile admitted to a Québec Chronicle-Telegraph reporter that "provincial information often winds up in the waste basket even though it is important material" because it is easy for English-speaking municipal councillors to dismiss information that is written only in French as having nothing to do with them. The newspaper reported that twenty of the Pontiac's twenty-five councils worked only in English (Québec Chronicle-Telegraph 05/29/71).

Many of the people I interviewed in 2010 still drew sharp distinctions between one small community and the next, distinguishing Bryson from Bristol from Campbell's Bay as if there was more distance between the communities than a few kilometres of bad highway and bush. Dorothy, for example, punctuated our interview with apologetic disclaimers that this or that statement about the region more generally "had nothing to do with Shawville". The distinct nature of each of the neighbouring communities (Bristol, Clarendon, Bryson, Norway Bay) was very clear in her mind. A Shawville Town Council meeting (again in 2010) during which the topic of retirement homes came up provides a particularly clear example of this perceived difference between communities. The council was listening to a report suggesting that funding for and (inevitably) oversight of these facilities was about to become part of the regional health provision mandate. The councillors expressed general alarm at the idea of losing local control of which people found space in which retirement home. One councillor made the issue personal 
by exclaiming, "Wouldn't I look cute in Fort Coulonge!" In her mind she would be entirely alien in the next community up the way, never mind in distant Fort Coulonge forty kilometres from her home in Shawville. The still active individuality of each community provides some insight into why the initial invitation to amalgamate in 1970 was ignored. Add to that a predisposition to assume that a dictate from Québec City had little to do with them and it is easy to see how talks about unwanted amalgamation (then as now) required by a distant official slipped to the bottom of the county's collective and individual agendas.

In contrast, the news in Tessier's 1971 paper that the Pontiac was to be severed into four pieces, with the Northern- and Southern-most communities parcelled off to the newly designated Gatineau Regional County Municipality and the Urban Community of the Outaouais (Aylmer-Hull) respectively, captured the region's attention. Tessier's announcement added to a growing climate of alarm initiated by increasing insistence on French as the language of government, early stirrings of Québec nationalism, the PQ's show of strength in the April 1970 election, and the abolition of Pontiac's "protected riding status". ${ }^{77}$ "Distant" Québec City suddenly felt much too close.

In April 1971 The Equity conducted a public opinion poll. Readers were asked to choose between possible "futures" for the region if Québec were to separate from Canada. 1,268 of the newspaper's 2,850 (44.5\%) subscribers responded: 603 (47.5\%) of them voted to join Ontario, $391(30.8 \%)$ to form a Federal District including parts of Eastern Ontario and West Québec, $231(18.2 \%)$ to become a "province by itself". Only $36(2.8 \%)$ people voted in favour of remaining part of a sovereign Québec. The Pontiac Journal, commenting on the poll's results, observed that, "[i]n many ways they already "live" in Ontario. They shop

47 The Pontiac's "protected riding status" made the provincial electoral riding's boundaries inviolable. The government's move to revoke that status was of obvious concern. It was easy to imagine that a population spread thinly along the river could and would be divided amongst neighbouring ridings in such a way that it would almost certainly be mis-represented, or not represented at all. 
across the river, work there, go to doctors in Pembroke, speak Valleyese"48 (Pontiac Journal 05/04/71). The large number of those in favour of joining Ontario came as no surprise.

It was equally unsurprising that the Mayor of Quyon, one of the communities slated to be annexed to Aylmer-Hull, should argue on behalf of his constituency that

we have nothing in common with the Hull area communities and we see no reason why we should be in their group... We weren't consulted when we were made part of that system last spring and the only reason I can imagine is because we are located in the national capital region.

(Ottawa Citizen 05/27/71)

I was struck by the Mayor's explicit rejection of mere location as sufficient cause for geographic attachment. It is also interesting that The Equity's Federal District option which included Ottawa and parts of Eastern Ontario enjoyed significant popular appeal while annexation to what was then called Hull, the Québec side of the national capital region, had none. The lines of separation and connection are complex, but they are expressed quite clearly. In this example, the experience of belonging underwrites perceptions of distance, connection and space.

Warden Quaile made an impassioned plea to the Québec City delegates.

Our request is for an open discussion and assessment of the problems peculiar to the County of Pontiac... with special consideration given to our ethnic and geographic factors... We ask that Pontiac County be given special status as a separate region known as the Pontiac Region, comprising all of the County of Pontiac as now defined on the electoral map... We feel our demand is justified in that Pontiac is

48 A further example of Shawville "already living in the Valley" is that the region receives CBC radio programming from the Ottawa studio, and listens to Valley Heritage Radio 98.7 and myFM 96.1 broadcast out of Renfrew. It does not share even English-language media with other English-speaking Québec communities. 
unlike any other county in the Province... We ask to have our correspondence in English to Municipal Councils that request it... At the same time we wish to thank you for the English translations of the White Paper.

(The Ottawa Citizen 06/02/71)

Quaile "became an overnight celebrity for having spoken boldly and in English at the mammoth conference" (The Equity 06/2/71:1). The Montréal Gazette's reporter, for example, was clearly impressed by Quaile's audacity: "If for nothing else today will be remembered as the day Basil Quaile demanded special status within a special-status Québec... He told the provincial municipal conference... that his county wants special status because "Pontiac is unlike any other county in the province" - and what's more because it doesn't want to work in French" (Montréal Gazette 05/28/71). Quaile's "bold" speech, while it did not win special status for 'The Pontiac' did win a reprieve, and a second chance to organize the county such that it could stay more or less intact as the MRC de Pontiac (Pontiac MRC). Since then the region has retained its character as an English-speaking "enclave" (David - retired school principal), and remains an "anomaly" in Québec as an English-majority community (Robert - geographer/farmer). Shawville is heavily invested in the sense of itself as an exception that motivated the Pontiac's demand for "special" treatment within Québec's own exceptional status. Feeling distinct, and projecting that distinction, supports the community's particularity and strengthens its resilience by reinforcing the rim of its resilience basin, the boundary around what it means to 'be' Shawville. 


\section{Invisible Space}

Shawville's particularity is enhanced by its invisible location in the shadow of Canada's National Capital Region. Shawville, the Pontiac, and indeed, the entire Upper Outaouais are hidden in various ways by the complex physical and symbolic presence of Ottawa-Gatineau. Sometimes the area is neglected behind contested space, sometimes it is excluded by the physical barrier of the Gatineau Hills, sometimes it is obscured by inclusion in data sets and studies that dilute its distinctness. Lying between the Gatineau Hills and the Ottawa River the Outaouais acts as a buffer zone "à la porte du Canada anglais... zone tampon coupé du reste du Québec " ["on the threshold of English Canada... cut off from the rest of Québec" (Frigon 2007:xxv translation mine)].

Shawville's physical distance from the rest of Québec as well as its social separation from Québec's Francophone self-identification is exaggerated by the proximity and location of the National Capital Region of Ottawa-Gatineau, a place which remains predominantly Anglophone despite determined efforts to mark it as bilingual space, especially since Canada's Royal Commission on Bilingualism and Biculturalism (1963-1969). In the 1970s, 4,000plus people were displaced and their homes in the old city of Hull were demolished to make room for Civil Service office towers, an action intended to affirm Canadian federal jurisdiction within Québec by stamping the region as bilingual, federal space. The politicized zone of "officially bilingual" Ottawa-Gatineau separates the Outaouais from the rest of Québec. In order to travel from the Outaouais (and the Pontiac at its upper end) to Montréal 
or Québec City the traveler must cross into Ontario through Ottawa-Gatineau. ${ }^{49}$ There is no viable road linking the two parts of Québec within Québec.

Added to the 'politicized' obstacle of Ottawa-Gatineau is the physical obstacle posed by Gatineau Park, $361 \mathrm{~km}^{2}$ (7km wide by $50 \mathrm{~km}$ long) set aside for recreation and conservation. The park, owned and managed by the National Capital Commission which is a federal body and therefore outside Québec's and Ontario's sway, plays a role in creating a no-man's-land between the Pontiac and the rest of the province that exaggerates Shawville's physical distance from Québec's administrative centres in Montréal and Québec City.

Shawville can also be rendered invisible by its inclusion in the Outaouais. Studies and statistics addressing Québec's 'regions' (Québec outside Montréal) tend to describe the Outaouais as if it consisted only of the amalgamated city of Gatineau (formerly Aylmer, Hull and Gatineau) and its immediate surroundings, a contraction that effectively erases the region's upper reaches. This excerpt from a Ministry of Agriculture, Fisheries and Food (MAPAQ) publication illustrates the point:

À proximité de la capitale fédérale, Ottawa, la région agricole de l'Outaouais bénéficie d'un bassin de plus d'un million de personnes caractérisé d'une population jeune, multiculturelle, active, scolarisée et relativement à l'aise ce qui en fait un marché prédisposé à l'achat de produits frais, nouveaux et à valeur ajoutée.

(MAPAQ 2011)

49 The most direct route from the Outaouais to Montréal is through Ottawa and onto Ontario Highway 417. Québec Highway 148 does go east along the north shore of the Ottawa River, through Buckingham, Thurso, Plaisance, Papineauville, Montebello etc. It is neither direct, nor in good repair, although it is a beautiful drive. Google maps says the trip is $207 \mathrm{~km}$ long and takes $2 \mathrm{hrs}$. and $45 \mathrm{~min}$. I have never heard anyone consider going to Montréal by that route. Highway 50 has been a work in progress for decades. It now reaches just beyond Buckingham from the Outaouais, petering out on a county road at Lochaber. From Montréal Hwy 50 reaches almost to Grenville. The gap is almost $100 \mathrm{~km}$ long. Significantly, although these alternatives exist they are not part of Shawville's "known" geography. 
[Being close to Ottawa, the federal capital, the agricultural Outaouais region benefits from a pool of over a million people characterised as young, multicultural, active, educated and comfortably well-off; a population that constitutes a market predisposed to purchase fresh, novel and value-added products.

(MAPAQ 2011 translation mine)]

MAPAQ's description of the Outaouais contrasts sharply with Shawville's reality in the region's upper end. The community of Shawville is aging, homogeneous, under-educated and relatively poor. Invisibility and erasure within regional studies and provincial government policy development strengthen Shawville's perceived distance from Québec by heightening its sense of exclusion.

Shawville's proximity to Ottawa-Gatineau contributes to sustaining an English-speaking population in the Village, and in Pontiac MRC more generally ${ }^{50}$ (Rudin 1985:187). Rudin credits the Pontiac's on-going English majority status to its proximity to Ontario and to the National Capital Region. He points out that, unlike English-speaking populations elsewhere in Québec, the English-speaking population of the Outaouais actually grew through the 1970s, driven by federal government expansion. English-speakers drawn from other provinces by the growth of the civil service and the region's booming economy settled on the Québec side of the Ottawa River in Aylmer and the new subdivisions of Gatineau. This expansion made the "situation in the Ottawa Valley exceptional" (Rudin 1985:188). ${ }^{51}$

50 In the 2006 census, 1,265 of Shawville's 1,495 residents registered their mother tongue as "English only", and only 195 of those mother-tongue-English-speakers claimed knowledge of French (Statistics Canada 2007).

51 Rudin refers to the Outaouais as the Ottawa Valley. His Valley takes in both the South and North shores of the Ottawa River. Frigon points out that what Québec technocrats now call the "Outaouais québécois" was until the 1960s called the "Nord de l'Outaouais", a change in nomenclature which, by a change in emphasis, moved the region from being the "North shore of the Otrawa River" to being the "Québec region of the Outaouais". The two terms name the same region with the same name albeit in two different languages. 
Caldwell confirms the Outaouais' exceptionality in a 1980 study of Québec's Englishspeaking populations outside Montréal:

l'Outaouais se distingue ici comme ailleurs : elle est la seule région ò la migration interprovinciale a progressé, d'une façon considerable entre 1966 - 1971 et 1971 '76".

(Caldwell 1980:68)

[Here as elsewhere the Outaouais is distinctive: it is the only region in which interprovincial migration grew to any considerable extent between 1966 and 1971, and $1971-76 "$ ".

(Caldwell 1980:68 translation mine)]

Government expansion onto the Québec side of (then) Ottawa-Hull in the 1970s played a role in securing the critical number of English-speakers needed to maintain the Englishlanguage services, shops and institutions necessary to supporting an English-speaking community.

However, Rudin's claim that the Outaouais' proximity was instrumental in supporting an on-going English-speaking community in the Pontiac was contested in the interviews I conducted in Shawville. While my interviewees confirmed that they made use of the shopping and cultural venues of Renfrew, Arnprior, and Ottawa regularly, they expressed more ambivalence vis-à-vis their relationship with Gatineau, even the English-speaking Aylmer section. Dorothy, for example, reported that in her childhood a shopping trip meant an expedition to Renfrew. Now, she goes to Ottawa

not Aylmer, there's nothing... with all the building they're doing in Aylmer there's no shopping centre there... nothing like Bayshore or Carlingwood [both identifiable locations in Ottawa]. We never go to, whatever they call that one [the big box plaza on the Plateau in Gatineau]. 
Bill and June agreed that while Shawville residents are more likely to go to Ottawa than Renfrew for shopping these days, it is definitely to Ottawa and not Aylmer (Gatineau) that they go (for both shopping and cultural activities like singing in a choir). I found that this assertion varied by age group. Shawville's oldest residents (seventy-five plus) tend to favour Renfrew as "familiar". The newly retired (or more adventurously mobile) consider Ottawa accessible, while many working people "travel" to Ottawa every day. (I have deliberately used travel rather than commute because that it how everyone described the daily drive - they "travel", i.e. they leave home).

Interviewees also described relying on Renfrew in particular as a source of employment, especially for summer and service-industry jobs. The number of Shawville's residents who 'travel' in to Ottawa daily for work is evidence of the importance and 'usefulness' of the city's proximity. However, as one interviewee pointed out, being “in the shadow of Ottawa's Peace Tower" has not been a ticket to prosperity. Proximity has not even ensured adequate roads and infrastructure.

The interview extract that follows reflects the speaker's sense of being invisible to and distant from "the powers that be" in Ottawa despite the city's relative proximity:

It really does seem like Pontiac doesn't exist... for all sorts of things like government grants and all that, as if Pontiac just fell off of Québec somewhere... When we came up here in '76 it was abominable when you looked at the roads - compared to just across the river when you looked at the roads, because the Ontario infrastructure was so much more... and yet that was still the Ottawa valley, the same distance from Ottawa. We used to always sort of laugh and think we were just in the shadow of the peace tower of Ottawa and yet the infrastructure and development here was almost nil, it was almost like Third World, still is in some parts. As a newspaper person it just seemed that nobody seemed to care about Pontiac. 
Another interviewee, Pat (nutritionist), identified a point on the highway where Aylmer with its new housing developments gets left behind and "it goes back to being the way it's always been". To Pat, "the way it's always been" is summed up in "the crumbling pioneer log barns and stuff like that" that replace the presence of growth and new construction along the highway. The abrupt reversion to the familiar is a visible symptom or symbol of Shawville's economic and social distance from the urban core, evidence that, as she says, "This place has kind of been lost somehow".

The contrast between the growth of communities at a similar distance to Ottawa on the Ontario side of the river (Trew (2009) names Embrun, Arnprior, and Carleton Place) ${ }^{52}$ and the economic inertia of the Pontiac is striking. Trew explains the difference in fortunes as politically motivated $(2009: 10)$, the result of a political climate my interviewees described as blowing "unfavourable winds" (John - physician), or as "backing the community into a corner" (Dan - UPA past-president).

Shawville's physical proximity to urban Outaouais, Ottawa and the Ontario border is clearly helpful, but it is vital to remember that Ontario and Québec are separated by an interprovincial border with national aspirations, given weight by latent and recurrent constitutional debates. Lack of distance does not equal proximity.

52 Statistics Canada 2012 provides numbers that confirm Trew's observations: Embrun pop 2006 - 5,655 $2011-6,380$ (12.8\% growth) / Arnprior pop. $2006-9,0762011-10,099$ (13.4\% growth) / : Carleton Place pop. 2006 - 9,453 2011 - 9,809 (3.8\% growth) / Pontiac MRC 2006- 145862011 - 14358 (-1.6 growth). Shawville's population shows growth for the same period, reflecting its relative stability as a largely retired population Shawville 2006 - 15872011 - 1664 (4.9\% growth). national average in same time span $5.9 \%$. 


\section{Anglo-Québec Space}

Shawville is also strikingly absent from accounts of the Anglo-Québec experience. Much of that literature focuses on the experiences of urban Montréal. The spring 2010 issue of Canadian Diversity/é Canadienne, for example, although it highlighted specifically the heterogeneity of English-speaking Québec, made no reference to Shawville, the Pontiac, or even the Outaouais (Jedwab 2010). Recent government-sponsored studies of Québec's English-speaking communities also overlook the Pontiac. For example, Going Forward: the evolution of Québec's English-speaking Community (2004) written for the Office of the Commissioner of Official Languages never acknowledges the distinctive experience of the rural Outaouais. Neither does the Community development plan for the English-speaking communities of Québec 2005-2010 written by the Québec Community Groups Network (2010).

The exclusion of the Pontiac and, indeed, the whole non-urban northern part of the Outaouais from Scowen's (1991) overview of English-speaking Québec is so blatant it appears deliberate. He writes:

The largest numbers of English Quebecers live close to the Ontario and the United States borders, in a belt running from the Aylmer-Buckingham area along the Ottawa River, through western and central Montréal, and into the Eastern Townships. There is also a high proportion of English Quebecers in a number of communities on the lower north shore of the St. Lawrence River.

(Scowen 1991:111)

The fact that he starts in Aylmer and takes his reader East (away from the English-speaking enclaves upriver on the Ottawa to the West), and then deliberately moves to include the communities on the St. Lawrence, makes it quite clear that he does not 'see' Pontiac County. 
Interestingly, Rudin (1985) is an exception that proves the rule beautifully. He does refer specifically to both the urban Outaouais (Hull) and Pontiac County, but he sees and names them as part of the Ottawa Valley $(1985: 34,57,64$, et alia).

Gary Caldwell makes specific mention of Shawville Village. He writes:

Quant au village de Shawville et à Clarendon, la municipalité rurale qui l'entoure, on y dénombrait, en 1971, une population anglophone de 3000 habitants, c'est-à-dire $95 \%$ de l'ensemble de la population. La grande majorité de ces anglophones, soit 90 $\%$, sont protestants, mais il s'agit ici de protestants irlandais : voilà donc, sans aucun doute, un regroupement unique en son genre!

(Caldwell 1980:83)

[As to the village of Shawville and the rural municipality of Clarendon that surrounds it, one could count, there, in 1971, an Anglophone population of 3,000 people, that is to say $95 \%$ of the total population. The vast majority of those Anglophones, some $90 \%$, are Protestants, but we are talking here about Irish Protestants: here is therefore, without a doubt, a population that is one of a kind!

(Caldwell 1980:83 translation mine)]

Invisibility on the one hand and incredulity on the other lend weight to a local perception of being both distanced from and distinctive within the province of Québec.

It is note-worthy that Anglo-Québec, or the notion of an English-speaking Québec community, did not exist before English-speakers in Québec felt the need to defend their language rights in the province. As Bill reported in his interview, "There is still no 'real' community, certainly not one that includes Shawville. Shawville is more Ottawa Valley than Anglo-Québec". I consider the context for this absence at greater length in Chapter Five when this study moves to investigate "identity" and identification as part of the scaffolding supporting Shawville's particularity. In this context it is enough to note the absence of a collective English-language community identity sufficient to give Shawville purchase within Québec. 


\section{“Ottawa Valley" Space}

The border dividing Québec from Ontario is less real than the boundary encircling the Ottawa Valley in Shawville's collective imagination. If you lift away the political lines that sever the Valley and look instead at a topographical map of the region the Ottawa Valley emerges as a single whole (see map on page 96). The Valley stands out as a "metaphoric island" with the Ottawa River running through its centre and the Gatineau and Opeongo hills as its "shores" (Finnigan in Trew 2009:7).

In his study of the upper Ottawa Valley timber trade Hirsch writes,

[A] kind of 'island' mentality prevailed in and above Bytown, hemmed in as the upper Ottawa was by the Laurentians on the north side of the river and, at no great distance, 'Shield' country to the west. It took two days to get to Montréal, the undisputed financial centre of what is now Québec and Ontario. Toronto might well have been a world apart, and was hardly aware of the backwoods drama to its east.

(Hirsch 1985:3)

Johanna Devlin Trew picks up the theme of the valley as island to remind us that

While a river may make a logical or convenient demarcation point on a map, in areas like the Valley settled before the construction of roads, it does not make a logical or convenient border since the pattern of settlement spread along both shores with the river as principal transportation link.

(Trew 2009:7)

A river can represent very different things as a line on a map, or as a circumstance of lived experience. Frigon writes, " La rivière des Outaouais continuera pendant longtemps à unir plutôt qu’à diviser les deux côtés de la vallée de l'Outaouais " ["The Ottawa River continued for a long time to unite rather than to divide the two sides of the Ottawa Valley" (2007: xxvii translation mine)]. Local Shawville historian Wyman MacKechnie echoes Frigon's claim 


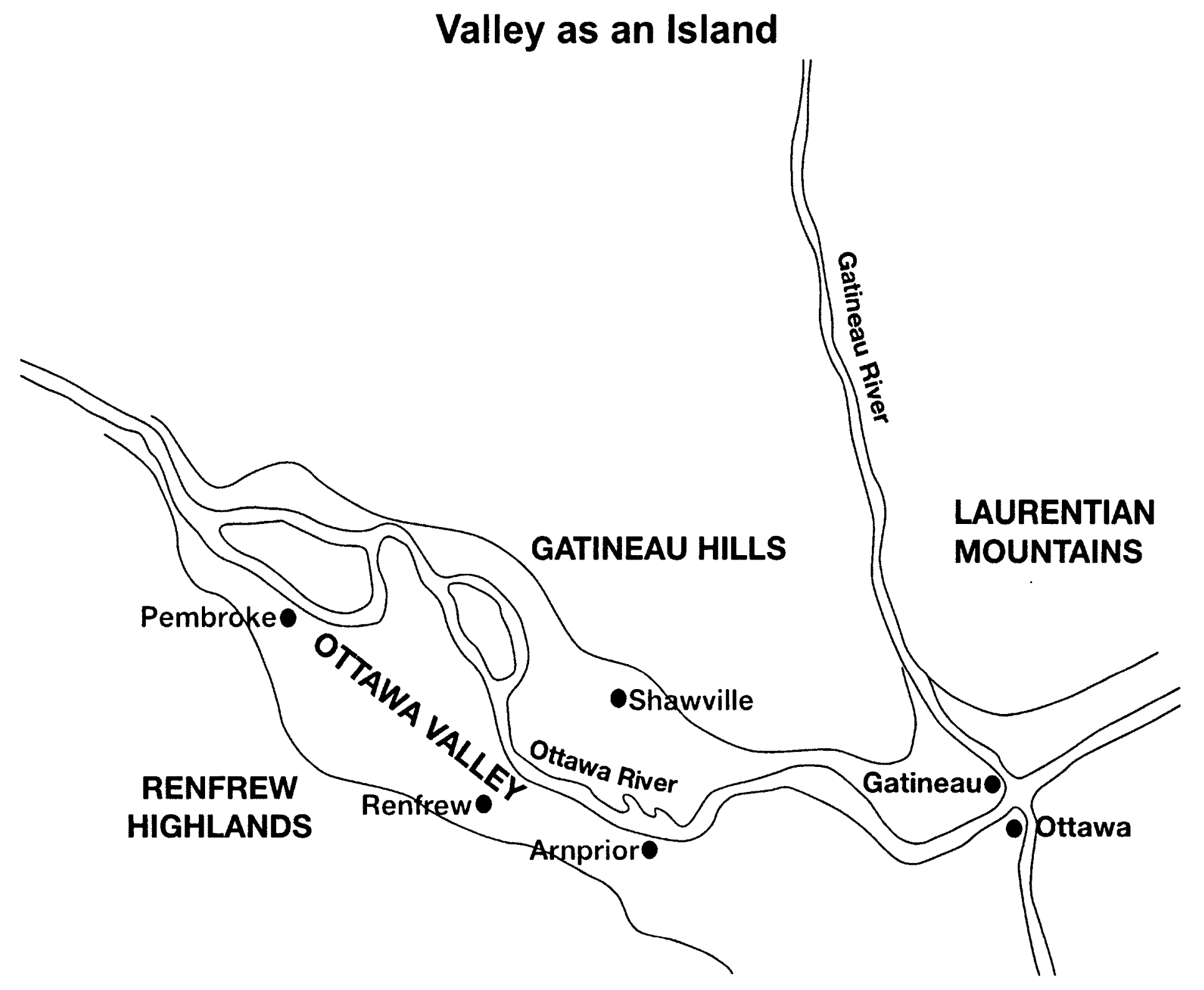


declaring that, "the Ottawa River was a bond, not a barrier, to brothers and cousins settling in the Ottawa Valley. It still is. May it always be so" (cited in Graham 2000:25).

Inclusion in the Ottawa Valley has played a central role in supporting Shawville's resilience. As Trew and Frigon remind us, the Ottawa River, although it forms a 'natural' (and easily naturalized) border between Québec and Ontario is, nonetheless, an arbitrary line. According to Frigon, the Ottawa-River-as-border obscures the complex intermixing of French and English on both sides of the river, and the equally complex relationship the English-and French-speaking communities share as a legacy of their long history together in the Ottawa Valley (2007:xxv-xxviii). Shawville situates itself within the Ottawa Valley and Pontiackers continue to bridge the river border with ease (Graham 2000:25).

The idea of the Ottawa Valley, its existence as an "imagined community" (Anderson 1983) constitutes a very real sense of place and community. Frigon claims that the valley (both figurative and literal) embraces both sides of the River and « fait abstraction de la frontière interprovinciale " ["makes the interprovincial border into an abstraction" (2007: xxviii translation mine)]. The real dividing line between French and English settlement in the Outaouais, he argues, is the north-south axis of the Gatineau and Rideau rivers. He claims that settlement patterns to the east and west of the Gatineau and Rideau rivers were and remain more definitely French and English. Local demands for secession from Québec at the time of the PQ victory in 1976, and playful (and not so playful) clamouring for the creation of a distinct status for the Pontiac in 1971, and a "Duchy of Pontiac" in the early 1990s suggest that many Pontiackers share Frigon's perspective that the lived experience of place and the political inscription of space are out of alignment. Shawville's lived and storied experience weaves its place into space in the Valley. 
Shawville is "part of the Ottawa Valley... We're all connected, yes. Well after working here at the archives I'd say that we're all part of the Ottawa Valley and then we're all part of Canada". [I asked her if jumping over Québec had been deliberate.] "No", she insisted, "I am a Quebecker. I was born in Québec. I'll be buried in Québec.

(Elsie - octogenarian/archivist)

The inconsistency in Elsie's declaration goes unnoticed. The North shore of the Ottawa River is both Valley space and Québec territory. It is a lived ambiguity.

One of the questions I asked at every interview was whether or not my interlocutor thought that proximity to Renfrew and Arnprior had helped Shawville to remain predominantly “English". Elsie's response was particularly insightful. She considered for a bit and then pointed out that Huntingdon, in contrast to Shawville, had "turned French" even though it was also close to English-speaking communities, admittedly in the United States. Huntingdon is eighty kilometres southwest of Montréal and less than 20 kilometres from the New York State border. Proximity did not prevent Huntingdon from "turning French". Huntingdon's Community Profile (Statistics Canada 2006) records a total population of 2,587 - 56\% French-speaking, $38 \%$ English-speaking and 3\% bilingual. ${ }^{53}$ In 1931, when Elsie was a child there, Huntingdon was 45\% English-speaking, 20\% French-speaking, and 33\% bilingual (Census of Canada 1931). ${ }^{54}$ How and why Huntingdon became a majority Francophone community is obviously another complex and interesting story. Within the scope of this discussion the significant thing is that, despite the proximity of Anglophone communities and their potential support in mitigating the loss of local English-language services and infrastructure, Huntingdon did "jump" from one state of "being" to another (slipping over the lip of its resilience basin).

53 Statistics Canada. 2007. Huntingdon, Québec (Code2469055) (table). 2006 Community Profiles. 2006 Census. Statistics Canada Catalogue no. 92-591-XWE. Ottawa. Released March 13, 2007, http:// www12.statcan.ca/census-recensement/2006/dp-pd/prof/92-591/index.cfm?Lang=E (accessed June 25, 2011).

54 Dominion Bureau of Statistics Canada. Seventh Census of Canada, 1931. Vol. II Population by Areas. 
The difference between Shawville's and Huntington's responses to linguistic pressure takes us back to resilience. Resilience Theory defines equilibrium as the amount of disturbance or disruption a system can accommodate without changing state; "jumping" to a new way of being as Huntingdon did when, in Elsie's words, it "turned French". Equilibrium, understood as the ability to remain in a particular state (within a particular 'basin'), relies on the breadth of the basin to accommodate variation within a given state and/or the centripetal strength of a zone of attraction to hold a system within a particular state. Resilience Theory, then, explains Shawville's persistence as English-speaking and distinct in terms of the strength or "pull" of a "zone of attraction" in which being English-speaking and distinct are significant and positive traits. The community's particular geography contributes to the community's stability by providing a context in which its distinguishing characteristics are reinforced because they are useful. By reinforcing Shawville's distinctness as a particular placel community, it's location inside and outside Québec, outside and inside the Ottawa Valley has contributed to Shawville's resilience.

Elsie's observation is also significant in that it suggests Shawville's proximity to Renfrew is less significant than its historic ties to the communities across the river and their shared sense of belonging to the Ottawa Valley. Proximity to other Anglophone populations was not enough to promote or support Huntingdon's "Englishness". This insufficiency suggests that the importance of Shawville's proximity to the Ottawa Valley is not about kilometres. I would argue that it is, in fact, less a question of being "close to" a particular space making specific goods and services accessible, than a question of being "part of" a particular place making a shared history and identity available. Shawville's proximity to the Ottawa Valley is tightly woven in shared experiences, ancestry, language and story. It is the relationship between Shawville and 'the Valley' which constitutes its perception of place within space. 


\section{Meaningful Space}

Trépanier (2005) describes collective identity as a recurring event. The self-identified community reforms and adapts its sense of itself in response to tensions that ebb and grow in significance, and fluctuate in relation to each other. The model she developed to study the work of identity formation and reformation within the political and historical Frenchspeaking Québécois community posits four "poles" or tensions in response to which that collective identity has renewed and rearticulated itself. She describes these tensions as: survival/assimilation (péril), exceptionality/exclusion (excentration), citizenship/nationality (appartenance) and renewal/conservation (rénovation d'histoire). ${ }^{55}$ Trépanier's model allows her to describe the central role of meaning-making in creating and supporting a community's identity. Each 'event' of identity affirmation (each incidence of lived collective identification) responds to the specific climate of its moment, reflecting the relative strength or imperative of the four poles at the time of instantiation. The community's self-expression balances the potential costs and advantages of privileging the tensions represented by one pole over those represented by another; the risk of taking too few risks or too many, being too concerned with continuity or not concerned enough.

By superimposing the poles from Trépanier's refondation model onto Resilience Theory's posited resilience basin it is possible to illustrate the relationship between 'sense making' and the human capacity for resilience (see figure on page 101). In my hybrid figure, Trépanier's four 'poles' serve as guy wires to stretch and anchor the outer rim of a resilience basin. They signify the limits to sense-making and therefore the limits to a zone of attraction. I use the modified model to support and illustrate the claim that the 'resilience basin' beneath a

55 Anne Trépanier has generously permitted me to use and adapt her concept (refondation) for the purposes of this work. The original work was written in French. The translation of her model into English is my own and reflects my understanding and interpretation of her ideas transposed into a new context. Ar her request, two of Trépanier's original models are included in the appendix to this work. 


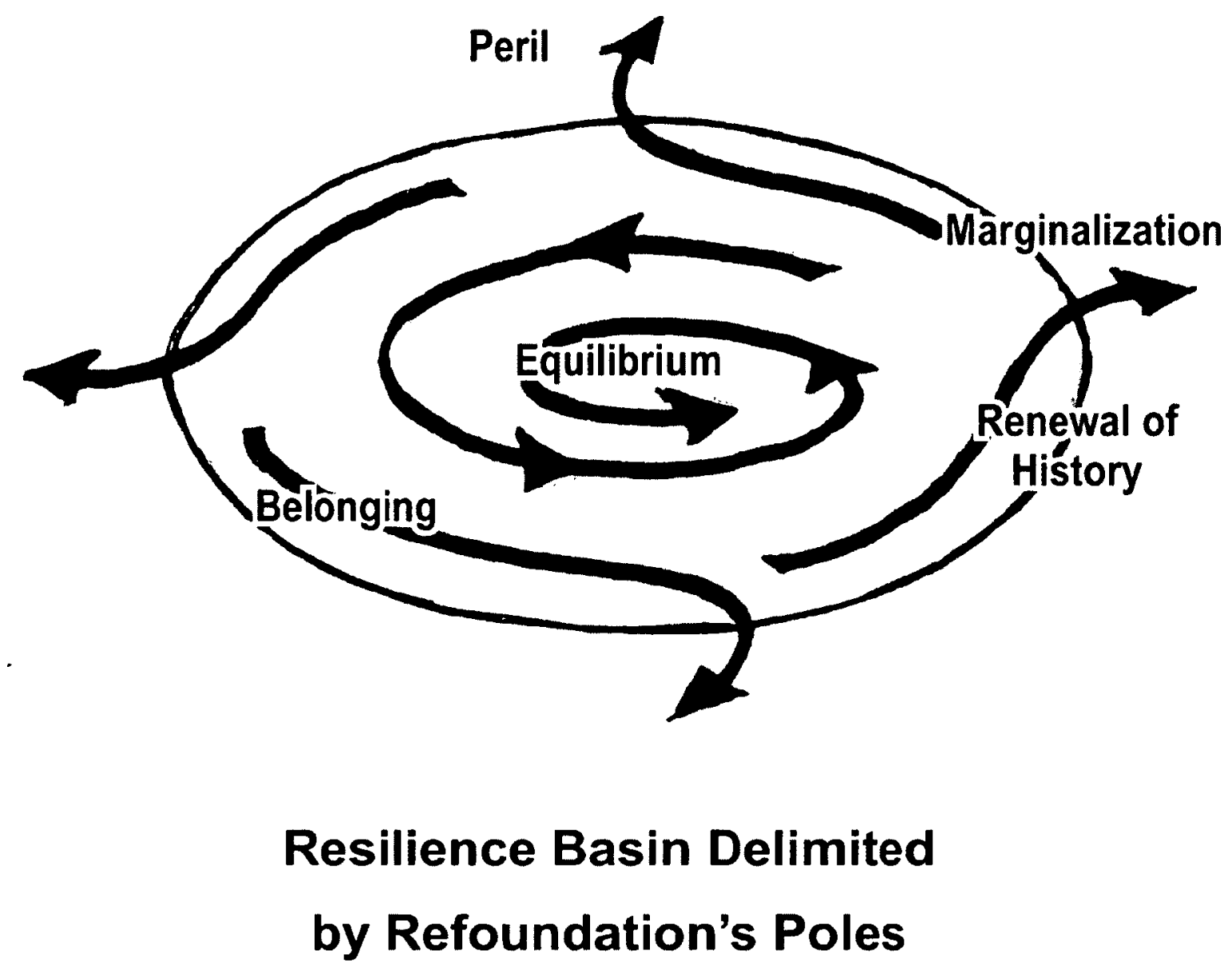


community's feet is as wide or as restricted as its capacity to make sense out of change and disturbance. Here we turn to Trépanier's refondation model to consider the role of meaningmaking in the identification of place.

Shawville's physical (river, valley, hills, and highway), political (inside and outside Québec), and social (outside and inside the Ottawa Valley) locations give specific values to the oppositions represented by each of Trépanier's 'poles'. For example, Jedwab's study of Anglophone Québec found that other English-speaking communities in the province feared exclusion, while Quaile's bid for "special status" for his community actually sought it, suggesting that Quaile and his colleagues saw incorporation into Québec as the greater threat. Quaile and the community he represented felt much more threatened by the prospect of assimilation into Québec than by exclusion from it. They placed a much higher value on continued inclusion in the Ottawa Valley, inclusion that was easy to make sense of within an already established narrative, inclusion that continues to be claimed and affirmed by Pontiackers.

Fearing assimilation into a Francophone Québec as a form of extinction Shawville insists that it does not belong in Québec. It wields its status as "distinct" and "unique" as a shield. ${ }^{56}$ Just as Basil Quaile's suit to the conference in Québec City rested on his conviction that the Pontiac was "unlike any other county in the province," Shawville's persistence as Shawville rests on its conviction that it is in fact "distinctive". Those who responded to The Equity's informal poll in April 1971 were happier to declare the region "independent" than to identify it as belonging to Québec. Because the community is deeply rooted in the Ottawa Valley the community can afford marginalization within Québec. It feels secure in an identification that both speaks to its sense of self, and centres it within a larger whole. As Debra suggested, "There'll be debate about "is that part of

56 As Québec once wielded its distinction and its French institutions as protection against English liberal capitalism (Warren 2003:67). 
the valley?" with some of the outlying areas. They're pretty close to not being part. But Shawville is core".

Stories, as an expression of sense-making, play a crucial role in the maintenance of an equilibrium basin. The breadth and stability of any "basin", the ground under a community's feet, is defined and limited by what that community can make meaningful. Individuals and communities use story to weave experience and circumstance together into something they can stand on. In this case, the community of Shawville has used story to construct a useful and usable sense of where they are.

\section{Conclusions}

Rocks and trees and water - the quintessential stuff of the Canadian Shield - play an obvious part in defining Shawville as a community. It is equally clear that both the place and the people have been shaped by relationships inside and beyond the region. The community has been formed by the expectations and experiences of those who live there, by their relationship to and relative status within the state, and by the contest over place and space particular to the community's situation on the Québec side of the Ottawa River. Shawville is a 'border' community. It finds itself in the space between English and French Canada, on the border between Québec and Ontario. It is on the margin between urban core and wilderness periphery. It is on the edge of 'real time' as a place for recreation and retirement.

Having identified where "here" is not in such a way as to confirm both exclusion from and marginalization within Québec, Shawville has put itself in a good place from which to affirm the continuity of its story, and its own distinct identity and location in the Ottawa Valley. While many English-speaking Quebeckers feel that the stories, symbols, and myths that once 
affirmed their sense of belonging are increasingly irrelevant (Marshall 1995:13), the people I interviewed spoke about continuity more than change. Robert (geographer/farmer), for example, claimed to experience his community as "a living museum" where everywhere he goes he finds stories planted by his grandparents still vital and fruit-bearing.

I argue that Shawville's uncomfortable situation astride the Québec/Ontario border plays a specific and significant role in the community's resilience by requiring it to become selfconsciously distinct. In the vocabulary of Trépanier's model, Shawville, confronted with the reality of its "excentration" from Québec despite its location within Québec has worked to cast this marginalization as exceptionality rather than exclusion. Shawville's contrary identity as an English-majority community in Québec is part of maintaining its distinct status. It is almost half a century now since the first stirrings of Québécois nationalism and the introduction of Québec's "Language Charter". Half a century is plenty of time to learn to function in a second language. It is time enough for a new sense of self to have grown up with and been assimilated by a new generation of the community. ${ }^{57}$ Shawville's "Englishness" should be considered a deliberate assertion of agency, a badge of distinction. The community's border location has helped to reinforce its "Englishness" because being English has been enough to ensure that Shawville remained "one of a kind", "a nation-state unto itself" (as one man from a nearby community called it). The need to recognize and accentuate its distinctive characteristics has both strengthened the drawing power of its 'zone of attraction' and clarified the boundaries of its equilibrium basin. Its ambivalent location between Québec and Ontario has contributed directly to Shawville's particularity and thus to the community's resilience.

57 There are examples of this generational reinvention in South Africa, parcicularly to do with the postapartheid generation (Neelin 2007: 90-91) - not to mention the biblical Exodus story, the archetypal narrative of cultural reinvention within a generation. 
In Chapter Four I change the 'slide' under the collide-o-scope lens to consider Shawville's resilience from a political economy perspective. The significant themes emerging from that study challenge the "common sense" tenets of much rural development work. In that chapter I argue that slow growth, cyclical (un)employment and relative isolation have preserved the community's particularity. Currently, Shawville's economy is supported by association with the farming community that surrounds it, and by returning retirees, drawn "home" by the very qualities that enhance the community's resilience, its slower pace of life, and its enduring particularity. The chapter will address some of the issues raised by a pension-dependent economy, and other challenges posed by the ethos of growth that drives so much of Canada's economic and socio-political agenda. 


\section{Chapter Four: Political Economy - River, Rails and Relationships}

\section{Introduction}

This chapter interrogates Shawville's economic resources and political relationships to ask how the community's distinct political economy, its staple resources, timber-focused infrastructure and social organization has contributed to its capacity for resilience. The chapter explores the role the particular political economy of this place has played in marking and maintaining its particularity. The slide we examine through the collide-o-scope lens assembles the unique set of resources, possibilities, precedents and constraints that constitute being Shawville. Most significantly, it draws attention to the reciprocal interplay of experience and perception (the making of meaning through story) in mediating the influence of its material circumstances. The interrelationship between material 'reality' and the world of ideas is, I believe, the crux of political economy. In Marxist vocabulary, it is the study of the economic 'structure' of society and its relationship to the 'superstructure' of law, politics and social consciousness it supports and is supported by (Bottomore 1988: 207). This link between economic and socio-political organization is very clear in Innis' work explored below.

The interviewees, in their accounts of 'being' Shawville, exemplify the way expectations shape and interpret their experience and the way that prior experiences colour and frame their expectations. In Shawville, the imperative that experience be made meaningful (the human need for meaning-making) is evident in the way events and circumstances are framed within community and individual narratives to fit shared ideas of "common sense". 
The interview data points to four features of Shawville's particular political economy that have bolstered the community's ability to manage change (disturbance) without changing its particular character (altering its state of 'being' Shawville). The first is the community's experience of 'employment' as episodic, a circumstance that comes and goes. Generations of experience with on-again off-again cycles of (un)employment play out in the expectation that "useful" skills can be put to work even when jobs are unavailable, and that neighbours and family can be counted on in times of trouble. ${ }^{58}$ The resulting mix of self-reliance and interdependence, together with the ability to fall back on flexible, useful skills has contributed to Shawville's resilience.

The second feature of Shawville's political economy that directly impacts the community's resilience is the existence of a farming community associated with the town. There is research demonstrating a direct link between the number of small to medium farms connected to a rural 'centre', and that community's capacity for social cohesion and collective effort. A third is the community's experienced isolation. Distance "from everywhere" (as many interviewees expressed it), real and perceived, socio-economic and political, has enhanced the community's natural inter-dependence and strengthened its internal competencies and resources. Together, inter-dependence and independence have strengthened the community's resilience. The final feature of Shawville's political economy this discussion will address is the community's slow rate of economic growth. Without a substantial economic driver to escalate the rate of change, Shawville has had the relative luxury of confronting and adjusting to change both outside and within the village at a manageable pace. The community has had sufficient time to take inevitable adaptive change in stride, incorporating it into the ongoing experience of being Shawville.

58 I learned recently, for example, that proceeds from the cash bar at a fund-raising event to support a family after a house fire are kept as a lump sum to be given to the next fire victims immediately after the disaster to tide them over until their event can be organized. The man I was speaking to (not a local) was impressed by the forethought and organization the plan exhibited, saying "They're used to fires". 
Shawville's resilience has been strengthened by the symbiotic and seasonal relationship between logging and farming, the presence of a farming community, relative isolation, and economic doldrums. The discussion that follows will show how each of these features has shaped and been shaped by Shawville's resources and socio-political organization. It also demonstrates how they contribute to motivating and providing for Shawville's resilience.

\section{Shawville's Political Economy: Some Context}

Shawville's current socio-economic situation is "the product of historical experience, human organization, and social interaction" (Brodie in Clement and Williams 1989:144). The objective of this first brief section is to place this moment of 'being' Shawville into the longer continuum of time and experience, as well as the wider scope of human organization and interaction that have shaped it. It is important to keep the idea of the mobile collideo-scope lens in mind. It will remind us that the motion of change is constant (adaptation, renewal, growth, and disturbance), and constantly textured and coloured by change at other scales. Shawville's resilience is manifest in its capacity to absorb change without changing its own state. The next few pages provide some context both for Shawville's present political economic circumstances, and for the way I interpret them.

One of the community's genesis narratives claims that Shawville was shaped by Napoleon's victory in a faraway European battle, even before the region was officially surveyed. ${ }^{59}$ The first European settlers arrived in the Outaouais just after 1800. Philemon Wright and his party came from Woburn, Massachusetts (the last trickle northward of United Empire Loyalists). ${ }^{60}$

59 According to Armstrong (1980) the area was first registered as the Township of Clarendon in 1792 although no legal survey was done until 1826.

60 Elliott suggests that while the end of the Napoleonic Wars in 1815 is generally recognized as a "watershed" in Irish immigration to Québec the earliest arrivals, like Wright and his party, are better understood as an extension of U.E.L. emigration after the 1770s (2004:250). 
Wright's famous exploit in 1806, floating a raft of timber down the Ottawa and St. Lawrence Rivers to Québec City, coincided by happenstance with a sudden boom in profits to be made from timber. Britain was eager to purchase tall straight Canadian pine trees as masts for its navy after Napoleon made the Baltic forests inaccessible. With the high price of timber to drive the industry's growth, logging quickly expanded up the Ottawa River valley.

The local economy became a nearly text-book-perfect example of the resource extraction/ staples-trap scenario that Harold Innis described (1962 [1930]). As in Innis' staples thesis, extraction industries (logging, mining and farming) provided resources for export, but few linkages (forward or backward) to enhance their profitability locally were ever developed. In most cases the necessary tools (fertilizers, tractors and chain saws) are still produced elsewhere, and the goods are processed elsewhere, meaning that whatever profit is made also ends up elsewhere. Innis' staples thesis has been in and out of favour since his seminal work The Fur Trade in Canada was first published in 1930. It might be simplistic to argue that Innis' thesis holds the key to Canada's political economy story, ${ }^{61}$ but it would be equally ill-considered to dismiss his work on Canada's economic history as no longer relevant. ${ }^{62}$ Clement claims that Innis' staples thesis remains a "logical point of departure" for any examination of Canadian political economy (1989:37). Arguably, it serves this study of a region built on forestry, mining and agriculture (staples) particularly well.

The most significant contribution Innis' thesis makes to this particular study is to raise some potentially fruitful questions. His work models a careful study of the relationship

61 "In the beginning there was Harold Innis / And his word was Staples / for without fish and fur and forests was not anything made in Canada that was made." With apologies to the author of John 1:1 - these are the first few lines of the playfully irreverent "rhyme" I wrote following my introduction to Canadian Political Economy and the illustrious figure of Harold Innis.

62 For a discussion of Innis's thesis and its relevance to Canadian Economic History see Daniel Drache and/or Mel Watkins in The New Canadian Political Economy Clement \& Williams (eds.) 1989. 
between economic production, the physical infrastructure it requires, and the sociopolitical organization that develops to support both infrastructure and production. His work exploring the role of "staples" (commodities explicitly exploited for export) as the root of Canada's economic development includes the insight that the character of what we harvest (be it trees or tourist dollars) affects how it must be 'harvested'. How it is harvested affects in turn the organization of space as well as the building of both physical and social infrastructure. How these are organized has an impact on future flexibility and options, and so on. These effects are both reciprocal and interconnected. They do not really constitute a clean causal chain. By signalling the existence of these relationships between economic production, the social production of space, and the construction of social identities, Innis opened up a useful line of questioning. His example leads us to explore the ways in which Pontiac region's exportable resources shaped and continue to shape the lives, expectations, and options of those who exploit and rely on them. The implication of Innis' observation is that the relationship between Shawville's resilience and its political economy involves more than the issue of financial viability. It suggests that social resources, competencies and expectations were also born of that relationship and make their own contribution to the community's resilience.

The particular requirements of logging and farming have clearly influenced the form of Shawville's socio-political organizations and determined the sort of material infrastructure the community has shaped and been shaped by. Forestry and farming had a symbiotic relationship in this region for over a hundred years. Although the towering pines that built its economy are gone, the region's identity and identification still rest on logging. More than a century ago Gourlay reported that "[l] umber absorbed the attention of everyone" (1896:141). According to Elliott, "hay and produce purchased in small quantities from thousands of individual farmers... fir[ed] the engines of the timber trade" (2004:241). 
Logging provided winter work for farmers and a market for local produce that made farming in the Pontiac viable. Seasonal employment, an expectation of flexibility, and the value of practical skills became normative. According to Shawville's narrative there is always the farm "to fall back on" and always some sort of work available in the bush. There are proven resources and strategies available to navigate what Walker and Salt call "the back loop" (2006:87), the "Omega to Alpha stages" of the adaptive cycle, the reiterative process of regrouping and renewal after disruption.

\section{The Particular 'Good' of Useful Skills}

Shawville's on-going experience of informal work and formal employment as cyclical and contingent contributes to the community's resilience by investing flexibility and interdependence with positive value. The early and long-standing relationship between logging and farming shaped local ideas about work in a way that normalized the need for "useful" skills and flexibility. Participation in agriculture had a part in constructing 'work' (task-based) and 'a job' (wage-based) as separate things in the collective imagination of Pontiackers. The experience of farming also contributed to a shared perception that some skills are inherently useful (i.e. practical and productive), and that re-inventing oneself, the work of adapting to changing circumstance, is both natural and achievable.

Robert, a retired farmer, articulated the importance of farming in defining and shaping his community.

Agriculture has been from day one. I mean, it was the founding part of the economy here. It's been the glue that holds things together... farming, yeah, through good times and bad, it's been an extremely important part of the fabric [of this community] Agriculture reinvents itself... I'd be almost much more optimistic about a place like this than anywhere because people have family, a lot of family around them. They've got family support, extended families. People can hunker down 
here more, if need be they can... you know, you can retrench and you can hunker down... I know it sounds silly, but people can reinvent themselves.

Farming is especially significant in Shawville which saw itself historically as the Pontiac's agricultural and commercial centre (Graham 1994:49). The fertile farmland around the town site made farm viability less dependent on supplementary income from logging. The advent of the railway in the mid-1880s gave farmers around Shawville even greater independence from logging by giving them access by rail to cash-based markets in Ottawa and Montréal. Being able to sell their produce for cash gave them an alternative to supplying the lumber camps on credit, and freed them from relying on accounts with Shawville merchants to see them through to spring and the log drive. Graham explains the domino-effect once the timber was delivered and paid for in the spring. The cash travelled back upstream, lumberman to farmer to merchant until all the layers of credit were settled (1994:60).

The sometimes positive, sometimes negative inter-relationship between logging and farming is relevant to this discussion of Shawville's resilience because it shaped the community's experience and interpretation of 'work' in a way that has proven beneficial to the community's persistence. Participation in both logging and farming, constrained as they are by seasonal realities, generated an experience of jobs (i.e. wages) as contingent and cyclical. Shawville's resilience has been enhanced by the experience of work as distinct from employment, and the community's consequent insistence on the value of useful, flexible skills.

The expectation that work would vary with the seasons and tasks shift with the needs of the day prepared the ground for the sort of sanguine resignation to cyclical employment voiced by my interviewees. For example, two of them described the more recent experience of mines and mills as employment that, like winter in the timber shanties, had a beginning and an end. 
Mines come and go. Paper mills come and go. Lumber mills, they run for a few years and then they burn down.

(Robert)

Unemployment's always been a challenge here, or employment's always been a challenge here. We've had mines that have come and gone - the Bristol mine, and even before that there was the iron mine, started back in the 1800s. It died and then they brought it back in the ' 50 s and then it died again, and then everybody went to work at the mill.

(Heather)

In my interview with Shawville's mayor, Albert, he admitted that, "One of the really big issues that our communities are having is a job thing... from Smurfit Stone way back to Hilton Mines". Although the mine's operation had been "dwindling" along with its supply of iron ore, several hundred jobs were lost when it closed in 1977. Some of those employees moved to Smurfit Stone's Mill. When the Mill closed in 2008, another few hundred jobs disappeared. Now, with even bush lot owners and portable sawmill operators out of work, the mayors of Shawville and Clarendon and their respective councils are working hard to attract new industry. They have created tax and loan incentives, met with prospective investors and entrepreneurs, "chatted up" local politicians, and set up a web site to spread the word. ${ }^{63}$ Mayor Albert's own employment history reflects an ethic of flexibility (bricklaying, mining, employment with Hydro Québec, municipal politics). Despite his obvious concern with the immediate situation, he expresses little doubt that the councils' plans will bear fruit. Something will turn up.

Albert is patiently convinced that just as the mill was there to catch the mine's laid off work force on the last go-'round, something will materialize to catch the mill's fallout this time. The certainty that something always turns up, points to the long-standing reliability of transferrable

63 Interview data collected spring and summer 2010. 
and 'useful' skills. He pointedly identified Shawville's early settlers as "great tradespeople who had pride in making sure their work was done properly... skilled tradespeople [who] brought their trades here with them". His words echoed the assertion, common to everyone I interviewed, that "trades" are a viable, responsible, and Alexible way to earn a living. They incorporate skills that can be put to work with or without the existence of waged employment. It is this flexibility in competence and expectations (and the make-do attitude it engenders) that enables the community to weather the inconsistencies of outside investment.

Robert (geographer/retired farmer), described what it was like to live in Shawville when the mine and the mills were open. Note that he emphasises the ability to stay in the community as the best of the good things such employment was able to offer. The ability to stay connected with 'home' as an assumed 'good' surfaced time and again in the interviews.

Hilton Mines provided a generation of young men with a living. They could stay here in the home community and raise a family. Financially, it was good money for them and ('cause most mines, especially in Canada, are in remote areas, people have to move far far far from home. They have to move up to the Arctic, Québec, Ontario, Alberta... ). Hilton Mines is quite unique in that it was in the middle of a civilized area, a community. So people who grew up here, like I said, a generation of young men could get work here and stay in the community. It was quite unique in that way... Another interesting with the mine too... It brought in some people from outside... like the mine management and the technical staff, from far way, the States or from different countries. They brought in a kind of a, a different, you know, new ideas, new people. That was nice. And then in ' 67 the Paper Mill again, it overlapped with the mine. Some people left the mine and went there, others just started up there. It was a huge source of employment for a whole generation. A large number of men were able to get through to their retirement and get to their pension, their company pension, before it went bankrupt. Once again they were able to stay in this community and raise their families instead of moving heaven knows where to find employment.

(Robert)

When I asked in another interview what became of the Mill's laid off work force (Smurfit Stone's closure in 2008) my interlocutor, a recently retired high school teacher, reported that 
"plenty of young people leave for work (like the jobs at the oil sands) and then make their way back". There is no longer any industry in the region. Locally, people rely on government services (the schools, hospital, and CLSCs) ${ }^{64}$ for employment opportunities. Many "travel" to Ottawa for work. Bill (retired teacher) described one of his early summer jobs as, "a good job at the mine. Back then the mine was a significant employer. There were 300 jobs lost when it closed". The Pulp mill was an even bigger source of jobs in its heyday. Where did all the onetime mill-workers go? "They retired, or took jobs here and there" (Bill).

"They got jobs elsewhere", Joan (also a retired high school teacher) reported, in answer to the same question about the mill workers' fates. "For example", she said, "[one man] who worked at the mine became the janitor at the school. A lot had skills that were very useful". Turning to the earlier mine closure (1977) she continued, "Everybody who lived along Hilton Ave... the management group, they went with the company somewhere else. Some went to Australia. That wasn't part of the whole Shawville fabric, though they were very much part of the community when they were here. But they had to, had to take a job as an engineer somewhere else". Jumping from the mine workers to the later mill employees, she observed, "a lot of the mill personnel, the upper echelons of the mill, they stayed, as they retired they stayed here. Quite a few widows here are widows of mill people, and they stayed. Maybe they became more a part of the fabric. Certainly they were a large group, and their kids all went to the school. The school was so big at that time".

In contrast to the specialized knowledge of the mining engineers who "had to take a job... somewhere else", Joan's comments stress that the mine workers' productive skills were key in finding new employment within the community. She listed the significant skills clearly: "Skills like welding, carpentry, auto mechanics, and plumbing. They're versatile, portable,

64 CLSC Centre Local de Service Communautaire - Local Community Service Centres. . 
and they're always in demand". Joan stated that as a high school teacher she had noticed a trend towards trades in educational choices. "Recently a lot of quite good grads from PHS [Pontiac High School] have chosen not to go to CEGEP, ${ }^{65}$ but to apprentice in electricity, plumbing, welding. It's happened in the last seven or eight years, really strong students are sort of swinging back to that." Her husband David observed,

I don't think we have the [anti-] trades bias that cities have. Trades are seen as a good profession. There's a tremendous under-the-table economy. Maybe that's part of rugged individualism too; looking after oneself... In Shawville if you're talking to someone who's going to be a plumber, you say "they're going to be rich". Compared to someone who has a master's degree and no job, a plumber's earning good money. He works in Ontario mind you, but he's home on weekends.

(David)

Here, again, the speaker points to the ability to touch base with home as an all-mitigating good.

Again and again my interviewees expressed the value of home and roots and relationships over the promise of better wages or increased status at the cost of mobility and disconnection. Robert, for one, described the alternative to his experience of continuity in decidedly negative terms as "being cast adrift". "We have a cabinet full of old things", he told me, "historical books, old Equity copies, and anecdotes my grandparents have written down. It's like a living museum for us. I mean, we can drive anywhere around here there are stories my grandparents told us".

There is a fuller consideration of the value of 'home' in the next chapter where I discuss its significant role in reinforcing identity and particularity. In this context, I want to flag specifically the relationships between specialized knowledge, generic skills and mobility. It is important to note that there is no lack of mobility in the latter relationship, generic skills

65 Collège d'enseignement général et professionnel (College of general and vocational education) 
can be transferred across space and taken elsewhere with little difficulty. The important thing is that they are also transferrable across tasks and being mobile in that sense they allow movement across space to be optional rather than required.

The answers to my questions about the fate of laid-off mill workers conflated many different rounds of layoffs and closures reinforcing my impression that they were understood as similar parts of a repeating whole. It is significant that the shift from unemployment to employment and back again is reported as a constant cycle which does not in itself constitute change. The differences berween the mine and the mill are also negated, their distinct work environments collapsed into their interchangeable status as employment. The coming and going of outside interests and investments is seen to be in its way as predictable as the seasons.

It is also noteworthy that in many cases the laid-off employees were reported to have made work for themselves. Holly and Jared (the youngest couple in my sample) told me that because their friends wanted to live their lives "here" at home, they had deliberately trained for the jobs available in local health and community development services, or were "making it happen" in other ways by establishing their own businesses as electricians, computer technicians and daycare providers. Gordon (teacher/academic) related that he and his brothers had also found ways to "come home and stay". Other interviewees suggested that the erstwhile mill workers were taken on by relatives, found jobs in construction, or put their "useful skills" to work in a variety of other ways.

The local response to the supermarket crisis discussed in the introduction is the most recent example of the mediating work of the narrative of cyclical ups and downs in action. There was a tone of practiced re-grouping at the town hall meeting in early June of 2011 when Shawville residents believed their supermarket was closed for good and there was every reason 
to panic. Using Holling's model of adaptive cycles, resilience theory would describe the community in that moment as being in a period of re-collection, working to put its feet back on the ground after a "disturbance" had knocked it off balance. The adaptive cycle involves re-positioning, followed by new growth, a time of stability, another disturbance... one step back, two steps forward, a change of weight to maintain equilibrium within the current "zone of attraction". The cycle isn't trying to 'go' anywhere, only to stay on its feet. 'The absence of any progress-assumed destination is important to this interpretation of resilience, borrowed as it is from environmental science. The most jarring note at that community meeting came from the Community Development Liaison Officer whose presentation insisted on "growth" as an assumed goal. "Growth" as an absolute value is not inherent to resilience. In fact "growth" inevitably leads to imbalance and makes "jumping" to a new state of being as a new kind of community inevitable. ${ }^{66}$ Survival in a new form might be an acceptable plan of last resort, but it seems an unlikely ideal. Growth is not the goal of resilience.

66 Jan Flora questions the growth-as-development imperative and offers an example of community development in which "the conversion of environmental capital to economic capital... resulted in deforestation, soil loss,, and agricultural chemical usage". He observes that rural scholars "have not yet taken a comprehensive look at how community "development" would have to change, were the dominant paradigm to shift to building sustainable [i.e. resilient] communities. He suggests that the first - and easiest step - would be to find a term to replace "community development" (1998:502 emphasis mine). Whether changing the word would prove sufficient waits to be seen. (There are certainly examples of the power of changed vocabulary (the push for gender inclusive language and its effect on the status of women in Canada is a good example). I agree that the attitudinal shift (away from a focus on growth) that might come with new vocabulary is the obvious place to begin. 


\section{The Particular Value of Family Farms}

Small to medium sized ("family") farms build and rely on strong social networks. For this reason their presence within a community contributes directly to its resilience. The number of farmers associated with a community relates directly to the number of volunteers at work in that community (Besser 2009:192). Shawville depends on volunteers. I was present at a Shawville Women's Institute (WI) meeting when a member of the Ladies Auxiliary "up at the Home" (Shawville's largest retirement residence) made a plea for extra help. The meeting approved a donation of money and several of the women agreed to help with particular projects despite the fact that none of them were members of fewer than three volunteer organizations. More than half of the WI members present were active or retired farmers.

Dan, past president of the local chapter of the Union of Agricultural Producers (UPA) began our interview boasting about his community's generosity and the effectiveness of local fundraisers. He was especially proud of the dialysis machine that the Shawville Lion's Club had recently bought for the hospital. He observed, "like for a depressed area we're supposed to be there's a pile of community money that goes into bigger projects rather than just the typical Lion's Club stuff... when you look at the dialysis machine like there's a lot of other communities that don't do that for their hospital. Despite the time crunch they experience, "for some reason the social groups are just filled with farmers". According to Dan, "you find time to do that". Elsie, one of the oldest contributors to my project described her community as one that "lives well with each other and works together... we attend each other's functions and get along well". Joan, an inveterate organizer of 'functions' herself, told me proudly that, "Shawville runs on volunteers". 
According to Besser (2009) farmers, in particular, find or make time to be those volunteers. His findings show that "the number of farms in the county... is directly related to... community participation, and organizational memberships". In other words, more farms (i.e. "a greater number of small farms") equals more participation in service clubs and social events and ergo "more bonding social capital and civic engagement" (2009:192). Towns with associated farming communities demonstrate greater social cohesion and social solidarity (significant ingredients of community resilience) than those without an associated farming community.

Bryden (1994) explains this correlation by pointing out that family farms rely on a solid social safery net. They survive, he observes, because they are "embedded in an array of non-market exchange relationships" (1994:70-1). The nature of farming (at the scale of the "family" farm) is such that economic well-being is not dissociated from the social environment. Dan (UPA past president) corroborated Bryden's claims. In our interview, speaking as a farmer himself, he described the exchange of labour, the sharing and/or coownership of farm equipment, mutual aid, information exchange, and the social support he and his colleagues count on. Jared and Holly, also farmers, underscored the role of family and community in their successes.

We couldn't have done it without the support of family. Networking and closeness make a small community special... They were there helping us put the hens in their cages - that's the sort of support we have, not just our community but our family. That's invaluable.

Consciously, or unconsciously, farmers invest in social solidarity and that investment pays dividends in their community's resilience. 
Recently, many rural geographers have turned their attention to the declining role of the family farm in shaping the rural landscape. The link between "Old MacDonald's Farm" and rural spaces has been so strong in the public imagination that the attempt to re-imagine "the rural" as distinct from agriculture has thrown the whole question of rural space into confusion (Bryden 1994, Bell 2007). In his Past President's Address to the Canadian Association of Geographers (CAG) in 1995, Troughton, already referred to in Chapter One of this work, presented a stark snapshot of Canada's rural reality. He reported that,

all major sectors of the rural resource economy, including agriculture, forestry, and fishing, and their associated communities, [have] experienced severe decline, coupled with increased urban-centred and corporate control... If one assesses the last 50 years, rural Canada has moved from a dominant position to that of dependence and residual status within the national system; the result is a system that is fragmented, increasingly powerless, and near collapse.

(Troughton 1995:290)

Recent statistics confirm that the declines continue. Troughton reported that between 1951 and 1971 the Maritime Provinces lost 58\% of regional farmland and 73\% of farms (1995:293). According to Statistics Canada the corresponding numbers for Québec were 36\% (farmland) and 78\% (farms). Between 1971 and 1991 the number of farms in Québec dropped a further $38 \%$. Between 1991 and 2011 they were down another $22.7 \%$. There are fewer and fewer farms and farmers. ${ }^{67}$

Many of the concerns about farming that were raised with me were neither new, nor unique to farming in the Pontiac: mobility costs, government regulation and the 'cost squeeze' (caught between the rising costs of seed and machinery and the falling returns from the sale of farm products), are significant issues both here and elsewhere. Regulation and accountability to various levels of oversight are clearly not new concerns, but according

67 Statistics Canada 2011, Census of Agriculture. 
to the farmers I spoke to they are growing in scope and intensity. Dan named increased regulation as the most important change he has experienced: "every time you turn around there's another book to do, and there's no income with that". He reported that farmers find the extra time for paper work by investing in bigger machines, tightening management techniques, or working harder - "you keep going till things get done". He was not alone in describing farming as changing and challenging work:

Of course farming is in a difficult situation these days. You can have all, I mean, we have all sorts of cattle but they're worth [pause] nothing. Let's be honest. And this diversification, eh, and how you try to make a little income? It always makes me think of my father who always had his finger (we used to say) his finger in another pie just so that when one, the income you're expecting, doesn't quite work out there's always something else to bring that bag of food home... Our generation got away from that... If you were a milk shipper you couldn't have horses in the same barn, or let's say pigs within the same building or that sort of thing, it [government regulation] really made you streamlined. And now you're going back to that so that when one doesn't support your family you've another means.

(Margaret retired teacher/farmer)

For the turf farm it's difficult to separate social change from industrial growth. Now we're a business, not so much a farm any more, a business with corporate branding. How that relates to community I'm not sure, but that's the business.

(Jared)

Growing up I didn't realize it but we probably didn't have very much... our own beef and dairy, we weren't hurting but... " [she described the farm expanding to make room for two brothers, and the workload growing, becoming too much work for her parents to retire] "No vegetable garden, no more canning. It's almost like you go more for less. The fast pace. Everybody is haggard at the end of the day... it's about speed and efficiency. Our system is broken.

Dan (40s), Robert (60s) and Jared (20s) all cited rising "input costs" as "the second major change" in farming. The price of food at the "farm gate" does not keep up with the cost of its production. All of the farmers describe themselves as "squeezed". Dan declared: 
The fifty acre farm is done - you either have to grow or become more efficient, or diversify... the old Elmer Fudd farmer plugging away in the mud trough, if somebody's doing that they have outside money that's letting them play like that. If you've got enough money to buy a farm you'd do better to just put it in the bank.

(Dan)

His comment echoes a quip about the cost of farming in an earlier interview in which my interviewee offered, "You can get a million dollar loan from the government. It's not much if you say it fast". Years ago at the Shawville Fair I overheard an elderly farmer answer the question, "What would you do with a million dollars?" posed by one of his friends with, "I'd just keep farming 'till it was gone". According to the Shawville area farmers I spoke to “ $\$ 100,000$ is nothing now".

In recognition of Pontiac MRC's economic situation the Québec government declared the area an $M R C$ Resource in 2003. This "special" underprivileged status gave the Pontiac access to tax incentives and grants intended to encourage economic growth. Funding under this programme favoured projects designed to "stimulate secondary and tertiary processing" (forward linkages) and/or encourage economic diversification. Between 2003 and 2008 fiftythree project files were developed and $\$ 16,775,000.00$ was invested in the Pontiac under the MRC Resource initiative (Commerce Pontiac n.d.). The subsequent development programme, called the Rural Pact, has injected more than $\$ 450,000.00$ into the region annually since it began in 2009 (CLD 2010:2). Also beginning in 2009, local "interested parties" were invited by the Pontiac MRC, CLD and $\mathrm{SADC}^{68}$ to participate in "a strategic planning process to redefine the socioeconomic future of [the region's] communities" (Pontiac Portal 2010).

$68 \mathrm{MRC}=$ Regional County Municipal; $\mathrm{CLD}=$ Local Development Center; SADC = Community Futures Development Corporation. - the French acronyms are always used, even where they bear no relationship to the organization's name in English. The practice creates a sense of living "in translation" whenever the local and the provincial make contact. 
When I asked the farmers in my interview sample about the various government sponsored programmes and initiatives the responses I received were ambivalent. There is no question that money gets spent; there are some questions about where and how the investments are made. According to one of my interviewees MAPAQ (Québec's Ministry of Agriculture, Fisheries and Food) is more interested in investing in the future than in supporting the "guys in the field" right now. To illustrate his point Dan told me about a recent rural development consultation where he was asked what he thought would be most helpful to support agriculture in the region:

They asked me, "What would be my big dream?" I said, "well, put a soy bean crushing plant up here". They said, "there's no soy beans grown up here", and I said, "well, if there were a crushing plant there would be". I said, "right now for us to send our crop to be crushed someplace else... its trucking that kills us". Half the profit's lost in the cost of transportation.

He did not feel that his point had been heard. Present initiatives are limited by the lack of local infrastructure, not imagination.

The difficulty of moving things and people into and out of the area is a major local topic. At that meeting the issue of mobility was expressed in terms of fuel and equipment costs. Elsewhere in our interview it was framed in terms of wasted time and effort. The nearest fertilizer dealer in Québec is in Thurso ("two hours there, two hours back", he said, while the "Ontario outfits" come to his door). There are separate licenses for Québec and Ontario so that buying fertilizer or seed in Ontario and "spreading" it in Québec means "two tests, two fees, two certificates". The alternative is the trek to Thurso. Distance, distant regulation makers, and little support in the here and now became familiar themes. 
Lots of government energy and money are spent on experiments in diversification; projects like hops production, rice cultivation, and sheep farming. Dan commented wryly on the relative merits of each idea. "The area is known for good forage, pasture. Sheep make sense here. But rice? I heard something about a six month growing season; we don't have six months". Interestingly, he credited the Parti Québecois with having been good to the region's farmers. He felt that because "Québec's separatist government was interested in food sovereignty", and because "French Québec continues to have deep ties to agriculture" the PQ government was "strong for farmers".

Robert agreed:

There've been a lot of advantages to being in Québec, farming especially. We've had huge advantages Ontario hasn't had. Financially, subsidies and programmes. It's like night and day trying to farm in Québec or in Ontario... Beef farmers have been heavily subsidized. Of course Ontario is free market. They have to sell at market price. They have no protection for low prices, bad years. The year with mad cow disease, 2003, we were all, everyone, was pretty discouraged, depressed, but we were heavily compensated. It was the best year, financially, beef farmers ever had. It's a terrible thing to say but it's the truth. Instead of being, you know, an apocalypse for us, it was... we didn't suffer at all, whereas in Ontario, other provinces, man, they just had to take their licks.

Given his favourable report on the Québec government's support of farmers in the 2003 Mad Cow crisis, I asked Robert specifically about the current efforts of the various economic development agencies and initiatives to diversify agriculture. His response was characteristically pithy, dismissing the forays into hops, rice and vineyards out of hand.

Well those things... nothing ever comes of... you read about them now and again. I don't think anything's ever come to fruition. Yeah, there are a few sheep farmers now. Yeah, there was a meeting a few weeks ago. Some of the young farmers are expressing interest in it. There seems to be a good market for spring lamb, the meat, some of the other products too I suppose. I know nothing about sheep. We never had any when I was growing up so I don't know anything about them. But you have to... with all 
the wolves around you pretty much have to keep them in a barn... it takes away a bit of the ah... it's kind of nice to see animals free range out of doors. I don't think you could possibly do it... Even the coyores now, they're getting so aggressive. You hear about them bothering cattle, anecdotally you hear about cattle being attacked, but sheep you know, they just love those things so... but if there was a market for them, it would be a nice option for people to have... There's a pall of death around the beef industry. Prices are really low.

(Robert)

Robert also shared Dan's opinion that government energies seem focused on rebuilding the forestry industry rather than supporting agriculture. He observes:

Sawmills get huge subsidies. They run for a few years and then they catch on fire and they burn. I hate to be cynical but these, you know, even this pellet plant here, ${ }^{69}$ if you do the math, all the millions they're going to put into it, for 60 people. They could just split it up among them for a lot less work.

(Robert)

The relationship between farming and forestry across the Pontiac has shifted over time. Where forestry once drove economic growth in the region, farming is now the more significant economic force. Despite this shift in economic importance, government diversification and development programmes continue to give priority to local projects that promise to revitalize the lumber industry over projects responding to current practices and problems among farmers. "Everybody says forestry is the number one industry, but it's not”, Dan protested. "Two years ago forestry had 11 million dollars in official receipts, but 11 million dollars of milk [alone] went out of this region." Nonetheless, when Canada's 2006 census reported that the rate of unemployment in Pontiac MRC was almost twice the national average ( $11.3 \%$ compared to $6.1 \%$ ) a letter to the editor in the local paper observed that "[a] lot of people are waiting for forestry to come back" (The Equity 2009/04/09 p.1). There are many others ready to argue that in order to move forward "We need to get our

69 A plant set up on the closed mill site at Davidson. 
forestry industry back on track" (Pontiac Journal du Pontiac 2009/10/21 p.45). It is easy to account for Graham's claim that "Pontiackers and all those who come from the Valley are essentially a timber people, no matter how many generations removed from the shanty" (Graham 2000:13).

Dan, in his capacity as president of the UPA's Pontiac branch (the Farmer's Union) argued with the MRC about its priorities, protesting that "a lot more MRC money goes into forestry than goes into agriculture". He cites Shawville's failed bid for a local slaughterhouse, the loss of Pontiac's own "milk pool", and the general lack of "transformation" facilities locally (like the soy processing plant of his wish list) as evidence that farming is neglected in development schemes.

I contend that the tendency of development planners to overlook all but value-added niche projects and agro-business-scale farming is tied to the idea that traditional farming is somehow pre-modern, an unsophisticated activity that knowledge economies will inevitably outgrow; an activity better engaged in elsewhere in the global marketplace, lower down the development chain. Midmore et al. (2010), in their evaluation of rural development policy report that funds and support directed at agriculture have proven particularly ineffective (perhaps even detrimental in that they have allowed the status quo to linger), basing this assessment on the precipitous decline in farm population even relative to rural population decline overall. They are concerned that desperate measures to prop-up shrinking and failing communities misuse public funds by diverting them from "higher return uses" elsewhere, and advocate "managing the decline" of communities that are unlikely to regain economic viability (Midmore et al. 2010:25). Farming, within the worldview Midmore et al. express, is on its way out. 
Being ready to accept the end of agriculture fits within a worldview that privileges 'the modern' and 'the new'. It is a set of assumptions and attitudes that values lumber as a player in 'modern' industry while it casts farming as 'primitive'. After all, lumber drove the region's development and gave individuals access to the cash economy. Tourist brochures and economic development policy put forestry centre stage. Shanties, log slides, and Alligator boats make good content for heritage tourism. Laying claim to the region's historical role as a major player on the national stage allows the region to set itself apart as an important destination. Shingle factories and pellet plants promise future industrial growth. Farming, according to a market driven worldview, is what you fall back on in between attempts at participating in the marketplace.

Twenty-first century Canadians have a distant and largely abstract relationship with farms and the rural countryside more generally. In our cultural imagination farms belong to an older generation, old ways, and olden days. Definitions of the rural are often negative. Rural space is perceived as 'non-urban' or, 'yet to be developed'. "Many see rural landscapes only as space to be crossed to reach 'somewhere' else" (Troughton 1995:300). Farms are emblematic of a set of values and characteristics (positive and negative) that all seem to have been superseded or upended by the current values of mobility, speed, and marketability. They are for many urban (especially Euro-Canadians) sites of nostalgia, not productive activity; as we drive away from "Grandpa's farm", the cottage, or a camp ground we feel that we are returning to the "real world" of urban modernity.

In order to think creatively and helpfully about rural places and spaces we need to recognize their double life as both a current lived experience and an iconic abstraction. Bell encourages rural scholars and policy makers to think in terms of the "rural plural" (2007:403) in order to respond to the complex mix of realities and fictions, assumptions and associations that are 
equally part of the 'rural' as it is currently constructed in both lay and academic discourse. Bell's principal concern is that we look past rural/urban as a dichotomy in order to see the rural on its own terms. As he says, we have "a fundamentally relative view of rurality, in which the rural is always understood with respect to, and immediately implies, the urban... the categories are dichotomous, with urban/metropolitan areas defined first, leaving rural/ nonmetropolitan areas as residuals". According to Bell, "[d]ichotomous ideas are often like that, epistemologically loaded onto one side of the split" (2007:405). His hope is that by seeing the "rural plural" (complex and contemporary rural reality) we will be able to think past this imbalance. He challenges scholars of rurality to conceptualize the rural as a complex and "real" part of a modernity that has expressions outside its Western industrial variant. ${ }^{70}$

Bell (2007) also critiques current discourse about rural places (academic and lay) for falling into one of two traps. We either define the rural in terms of space and population, something that can be mapped and counted; or in terms of associations, something mythical, separate from real power struggles. The rural countryside is made distinct from 'here and now' either by removal into the past, or by displacement into leisure time. Bell argues that it is vital (and possible, he quips, since we are blessed with two eyes) to see both the "mater-real" (concrete) and the "idea-real" (abstract) faces of rurality at the same time (2007:403). We need the 'thick' blend of empirical observation and emotional perception to understand what we are looking at. Fact and fantasy are mutually constitutive and reinforcing in the social construction of rural places, particularly among those who do not live in 'rural' space.

In terms of this discussion, Bell's most important observation is that both definitions limit us (we urban academics in particular) to a view of the rural as "other" to the urban in a way that privileges the urban as normative. Both definitions make it possible for development

70 Appadurai (1996) 
programmes and policies to treat rural places and people as "survivals" to be gently ushered into oblivion in the interest of progress, or as artefacts to be commodified for their heritage or curiosity value. The work of Markey et al. (2008), for example, advocates "place-based" thinking (2008:409) as a way to bring "a greater diversity of values (and understanding of value) to economic development" policy (2008:410). Their discussion focuses on issues of local "branding" and the "value added" potential of one-of-a-kind, place-specific offerings for the market. By my reading, their analysis of alternative values reduced the significance of the place-specific matrix of culture, environment and community to that of an asset with marketable potential. The possibility of uncovering alternative metrics of value by engaging in place-based thinking was left undeveloped (2008:411-12). Their objective was limited to pushing beyond the idea of rural places as "resource banks" in order to engage more effectively in commodifying their place-specific goods. It did not extend to exploring the possibility of rejecting commodification. The assumption of marketability as the value to be added is so ubiquitous that development in many models equals commodification.

In a more recent work Markey et al. (2012) apply place-based thinking to a study of the potential development of Northern B.C. This time the authors focus on the need to build "communities and regional economies of permanence" instead of "treating the region as a resource frontier" (2012:4-5). Here again the form of development they advocate is intended to maximize participation in the market. The authors write, "We must invest in B.C's rural and small town communities so that we are ready to take full economic advantage of future economic upswings (across a wide range of economic opportunities) as they unfold, instead of playing catch up because of a lack of preparation (2012:8). The goal of development thus becomes to enhance the "economic, environmental, cultural and community dimensions of place" in order to encourage investment, and build the flexibility "so critical to keeping up with the pace of global economic change" (2012:13). Flexibility, I have argued, is also vital 
to keeping that pace in check to allow time to accommodate disruption. The most important investments to be made in particular place/communities are those that strengthen the relationships that support resilience.

Besser argues that the valuable resource "that inheres within the structure of the relationships between members of a group or community" (2009:185) is difficult to see and value appropriately when we misname it "social capital". Our tendency to understand "capital" as property and therefore individual (transferrable, exchangeable, interchangeable), separates it from its ontological source. Bryden argues that this, the separation of people, community, productivity and place from each other, is precisely the root of unsustainability (construed here as the opposite of resilience). Unsustainability, he states, is the product of "distanciation, separation and alienation" (Bryden 1994:215). With this claim he joins Troughton in calling for new analytical frameworks that will better support the potential of rural placel communities and slow their decline, "frameworks that can handle both people issues and nature issues" (Bryden 1994:216), that will "rebuild the connections between people and nature, social science and science, people and community, people and civil society, and people and the state" (Bryden 1994:221). Again we see the imperative of connections challenging the modern zeitgeist of mobility and the ideal of an undifferentiated terrain. It is connection that sustains communities, and communities that produce the valuable resource that inheres in connection.

Small to medium scale farms cannot generate enough income fast enough to keep up with the increasing costs associated with mechanization and the increasing pressures of regulation. Where agriculture was once considered to be the most appropriate appropriation of land (Gourlay's 'smiling' fields and fences of civilized space), now it could be argued agriculture turns investment into profit too slowly (if at all), and is not intense enough to maximize profitability. 
Now instead of cultivating the land as the highest form of resource stewardship, we 'develop' it, concentrating its worth as an asset, and intensifying the rate and quantity of returns.

Neither intensified land development nor the intensified practices of agro-business are good for community resilience. Troughton points out that "the industrial model [of farming] leads to much higher levels of production and gross return per farm, per acre, and per person, but it is reductionist in that fewer farms are needed and fewer survive in what becomes a highly competitive process" (1995:296). The inherent value of the medium to small-scale family operation of nostalgic imagination lies specifically in its reliance on social networks and the reciprocal exchange of time and resources. The existence of networks and exchange relies on the presence of a community of other farmers. There is a direct correlation between the social cohesion and well-being of a rural village and the presence of an associated farm community. The existence and number of family farms around Shawville has contributed to the community's resilience. "Farming," I was told more than once, "is the glue that holds things together". Fewer farms might prove unable to regenerate that glue.

\section{The Particular Value of Relative Isolation}

Shawville's isolation, the product of both geophysical and socio-political realities as we saw in Chapter Three, has bolstered the community's independence and interdependence. Feeling distanced from the world around it has given the community space to nurture and protect its particularity. The costs of participation in as well as exclusion from wider markets and increased competition have both been moderated by an unconscious mixture of attitude and accident, the community's "tightness" and its "invisible" location. Shawville's relative isolation has reinforced its resilience by strengthening its centripetal core and giving definition to its boundaries. Particularity requires enough ontological separation from the hegemonic whole 
to allow one place to distinguish itself from another. Space of that kind is becoming a rarity.

There is plenty of evidence of both the community's tight inter-connection, and its determined independence in the data I collected. The following interview excerpts exemplify Shawville's self-sufficient attitude, a self-sufficiency that is both individual and collective. It is an independence that is also interdependent. One interviewee described Shawville's "internal culture" as "a sense of autonomy":

I mean a sense that nobody is going to do it for us so we have to do it for ourselves that is buttressed by being a primarily Anglophone community in Québec and having the expectation that the political winds are not particularly favourable. Even though in the news right now they're talking about services to Anglophones, ${ }^{71}$ it's still a hard slog to even get all our hospital stuff translated into English, and all the administrative stuff... so there's a sense, and it's not a complainy sense, it's almost a sense that, well it's probably better that way, that we're in charge of our own destiny to some extent. They can't control mill closures and employment opportunities and what not but they can control the cultural interaction aspects and that keeps it ticking.

(John-physician)

English Quebeckers have always been individualists. The idea of clumping together to tell their own story isn't... That's probably more an indicator of the two solitudes than anything else - this idea that we're individuals. We don't worry about clumping together. We just are. We just do. Somebody who I was talking to, they took a course or something in Anglo-Québec history and they noticed the difference between the English community and the French community was if the French community needed something done they went to the Church or the Seigneur or whatever and waited to see if it got done, and the English community just went ahead and did it. They didn't worry about permission. They needed a school, somebody donated the land. They went out and they got started, took up a collection and away they went.

(Gordon - historian/teacher)

I was very surprised when I heard B** pass the comment that he had lived in Shawville for more than 25 years and that he did not feel like he was what I would classify as a 'Shawvillite'. That really took me back. Because at that point I questioned our

71 The speaker is referring to a survey conducted in the summer of 2010 to study the availability and accessibility of English-language health services in rural Québec. 
community as being welcoming, and if you talk to some of the, ah... it's almost a joke among some of us in our church unit that, "Oh well, she's a Shawvillite", that if you are an original somehow it's different. I would hate to think that however... because I've always lived here, I wasn't aware of that... but $\mathrm{E}^{* *}$ still passes that comment you know, that she's "married in", and it's still different. We tease her about that.

(Margaret-Shawville 'original')

People think to themselves, "what do you know, you're not from here?" There's teachers and nurses but the other ones, "why are they here?"... Perhaps people are conscious of their own oddness... Maybe when you're part of such a large extended family, you don't feel much need to venture out and meet new people.

(Elaine - "married in")

I had an interesting conversation one time with two teachers who were retired from here. They had been here 30 years, so they had done almost their entire teaching career here in Shawville, raised a family here, purchased a house. And as they were approaching retirement, a member of the community said, "so once you retire will you be going back home?" 'Home' was the eastern townships, that's where they'd come from. And I remember her saying, "I've been here 30 years, and been involved in things". And there was still that - will you be going back home? ...that's what I mean, that it's a very close knit community. I think it has its advantages, but it may be hard to break in a little bit. "They're not from here" It's almost said by way of an explanation sometimes.

(Debra - school vice-principallyoung mother)

In a political climate that favours the amalgamation of small 'particular' places into larger administrative spaces in the name of efficiency, the value of particularity is overlooked. The mayor of Clarendon Township, Jack, pointed to a growing number of increasingly centralized regulations as a 'change' he has experienced since the beginning of his time in office. He used new regulations upgrading firefighter training as a case in point. A one hundred and fifty hour training course recently became mandatory. The course is available in English (never a given in his experience), but it is all 'online'. The mayor was clearly indignant. "For someone who's volunteering his time - all on the computer!? The older guys all quit. You lose all that expertise." Jack feels that centralized regulations only complicate life for small municipalities. 
"The central government dreams up a new plan, but they don't send an envelope to cover the costs of the scheme."

Shawville's Mayor, Albert, concurs. Increasingly centralized regulation and increasingly expensive responsibilities are taking a toll on small municipalities and local governments. "As far as I'm concerned", he put forward, "that's the biggest change in the last fifteen years - the downloading of responsibilities". Environmental regulations have meant upgrading sewage treatment, water distribution, and even snow ploughing practices to meet new standards. Accountability regulations have meant new paper trails and increased paper work. The only thing decreasing is the community's tax base. Albert also raised the issue of the new course and exams for fire fighters, obviously a recent and contentious issue. He attributes the increase in regulations to concerns about liability and pressure from insurance companies, and protests their imposition in the context of his small community. "Something happened in Timbuktu, so everybody's got to take the courses. They take the same courses here as they take in Montréal and Gatineau." Centralized regulation makes no allowances for small towns with small budgets or for the very particular circumstances of volunteer fire brigades responsible for huge areas. The Mayor is tempted to think that government (at both the provincial and federal levels) is deliberately putting pressure on small municipalities to amalgamate. He cites one of Shawville's councillors who insists the government is out to "break" them, to make the amalgamation of rural districts inevitable.

Other interviewees also expressed a sense that isolation is fast becoming a thing of the past.

I think our town is very happy to call itself kinda isolated and to itself, but I think suddenly it's not. There's so many new people are moving in. The hospital is bringing so many foreign doctors and people who are settling here where they can commute to the city. Whether we like it or not we have to be part of the bigger world. 
You used to hear it a lot, "Nobody knows where we are and that's the way it is". Not anymore.

There is a clear consensus in the interview data I collected that isolation in the form of autonomy is "good". People were pleased and proud to tout their independence, determination and "can-do" attitude. The question of isolation as a product of actual distance (poor roads and a sense of exclusion) elicited a more ambivalent response. The issue of Shawville being "far from everywhere" invites a more nuanced investigation. The next few pages tell the story of the Pontiac Pacific Junction Railway as an example of the complex interplay of political and economic decisions. The railway played an important part in shaping the region's fortunes. It can be said to have created distance even as it built connections.

A railroad is a tool of geo-graphing par excellence (returning to the discussion of Ó Tuathail and "earth-writing" as an act of human will introduced in Chapter Three). The rail bed, ries and tracks stretched across the landscape sever and connect, bridge and tunnel, survey and map; they organize, occupy and administer space in just the way Ó Tuathail describes the act of geo-graphing. A railroad is not neutral. It is a tool of significant power that inscribes geography onto space.

Like $O$ Tuathail, Brodie emphasises the role of human agency in the organization of space (1990:17). She describes the processes that make space into place as "relational, historical, reciprocal and cumulative" (1990:55). Places are distinguished from each other by their relationships to each other. These relationships have histories. They (places, relationships and histories), have all been shaped by their interactions over time. These ideas speak directly to Shawville's present location as an isolated back-water despite its proximity to Ottawa- 
Gatineau. While, as Brodie argues, it has become commonplace in Canada to think of regions as salient socio-economic units and so adopt a "politics of place" (Brodie in Clement 1997:240), the tendency to think of social, economic and political problems in spatial terms (often pitting one region against another) overlooks the non-space-related issues that perpetuate those problems (Brodie 1990:17). Economic and political decisions, like those made by the business interests that left the PPJ Railway through the Pontiac unfinished, have played a role in creating Shawville's present location. The unfinished railroad is especially complicit in the exaggerated perception of being "far from everywhere".

Graham opens his study of transportation in the Pontiac with the of repeated quip "You can't get there from here." 72 Mobility, or the lack of it, has been a long-standing challenge in this region. The conviction that if only there were an efficient way to move goods and people into and out of the area prosperity would follow goes back a long way. It was this conviction that inspired the construction of the Pontiac Pacific Junction Railway (the PPJ) through Pontiac County in the 1880 s. Graham, a railroad enthusiast, writes that the railway was worked for and welcomed as "the one event that would precipitate a golden age for the region" (1994:8). There was an undeniable boom in real estate prices and construction in the villages along the proposed route, as well as a burst of jobs directly related to laying the track. The railroad made some mining operations in the area viable, and the cash-based markets of Ottawa and Montréal more accessible, loosening the ties between local producers and the hungry logging shanties (Graham 1994:60). The lumber 'barons' who keenly promoted the railway anticipated that the train would make it easier to supply their camps. As it turned out the rails ended in Waltham, twenty seven kilometres short of the junction with CP Rail in Pembroke. They were too far south to serve many of the logging camps, and snow made horse and sleigh a more viable form of transport into the winter shanties even

72 From Gord Graham's Suffering from a Want of Communication page 5. 
where the railroad did run (Graham 1994:61). It is characteristic of the adaptive cycle that by facilitating the sale of local produce elsewhere and for cash, the rails the lumber interests worked for might in fact have had a negative effect on the availability of winter supplies for the shanties. Change reacts to change; it does not have a destination. It is unpredictable. It is not always an improvement.

Gourlay (1896), who is altogether less enthusiastic than Graham about the railway, points to the landmarks erased by the new reality of the railroads. Trains brought high quality wheat from the prairies and flooded the local wheat market driving "great changes" that led to "new modes of farming" and altered the region's landscape. Wheat fields gave way to pastures and dairy cows, and the blacksmith shops and small hamlets along the buggy roads once supported by the need for horse-shoeing, sleigh-shoeing and wagon repair "fell away" as horse-drawn traffic thinned (Gourlay 1896:195). The railroad was not without negative side effects. Even Graham concedes that "Pontiac was now easier to get to, but it was also easier to leave". Even as the region entered a time of prosperity "it began to lose people... attracted to the abundant farmland of the west" and the opportunities of the city (Graham 2000:33).

The story of the Pontiac's changing mobility needs clearly illustrates the adaptive cycle in motion. Each adaptation both resolves an old problem and opens a new one making the twosteps-forward-one-step-back dance visible: disturbance, regrouping, growth, consolidation, new disturbance. The railroad was built when the river no longer answered Pontiac County's need for mobility. The river was full of obstacles; waterfalls, rocks and rapids. Once the forest had been cleared enough to make land travel imaginable the river came to be seen as a less-than-ideal highway. Neither river nor rudimentary roads would serve once the goal was moving bulk commodities (Graham 1994:4). Unfortunately, the railroad could not meet the county's most pressing need for transportation in and out of the logging shanties 
(they continued to be supplied via the river and by horse and sleigh long after the rails were laid), nor did it prove a viable alternative to shipping squared timber as rafts down the river itself. The railway was never completed at the upper end so it failed to connect the region to cross-Canada rail traffic. It also saddled Shawville with a tremendous debt, money paid to the PPJ Company to ensure the village would not be bypassed by the railroad. The community carried that debt, and the legal costs associated with contesting its payment, into the $1930 \mathrm{~s}$ (Gourlay 1896:197, Graham 2000:31, 33, 37 et alia). ${ }^{73}$ When the railway no longer met the Pontiac's changing mobility requirements the highway replaced it.

\section{Rails \& Relationships}

In the end, the railway's most significant impact was the way it changed the relationship between places within the Pontiac. The county's economic centre of gravity moved from the river to the rails (see map on page 140). Towns along the railroad grew while those along the river did not. Pontiac and Union villages, at either end of the horse railroad around Chats Falls disappeared (Graham 2000:35). Traffic up and down the river was superseded by the faster and easier rails, but cross-river traffic was actually reinforced. The rails on the south shore of the Ottawa River (in Ontario) reached Sand Point in 1866. Even after the PPJ was built, the station at Sand Point remained more accessible to farmers along the river front than the PPJ rails which were further inland and had to be accessed by road. Sawn lumber and shingles were shipped into the Pontiac from Braeside, Bristol homes were built with

73 The issue of "the Bonus" Shawville paid to the PPJ Company remains contentious. While Graham sees it as an inevitable cost of doing business, something the community had to pay or be left behind, others blame it for the region's "continued economic retardation" (Graham 2000:31). My own opinion is that there is nothing inevitable about "progress", its costs or its advantages. I see the same unthinking acquiescence to staggering costs in the name of progress being played out in investments made to "connect" the area with cyberspace and the information highway. Like 'the bonus' the costs are enormous and the long term implications of investment cannor be guessed at. Certainly, railroad enthusiasts could not have foreseen that the railroad would be pulled up again in just less than a century. 


\section{Mobility: Railroads, Highways and the River}

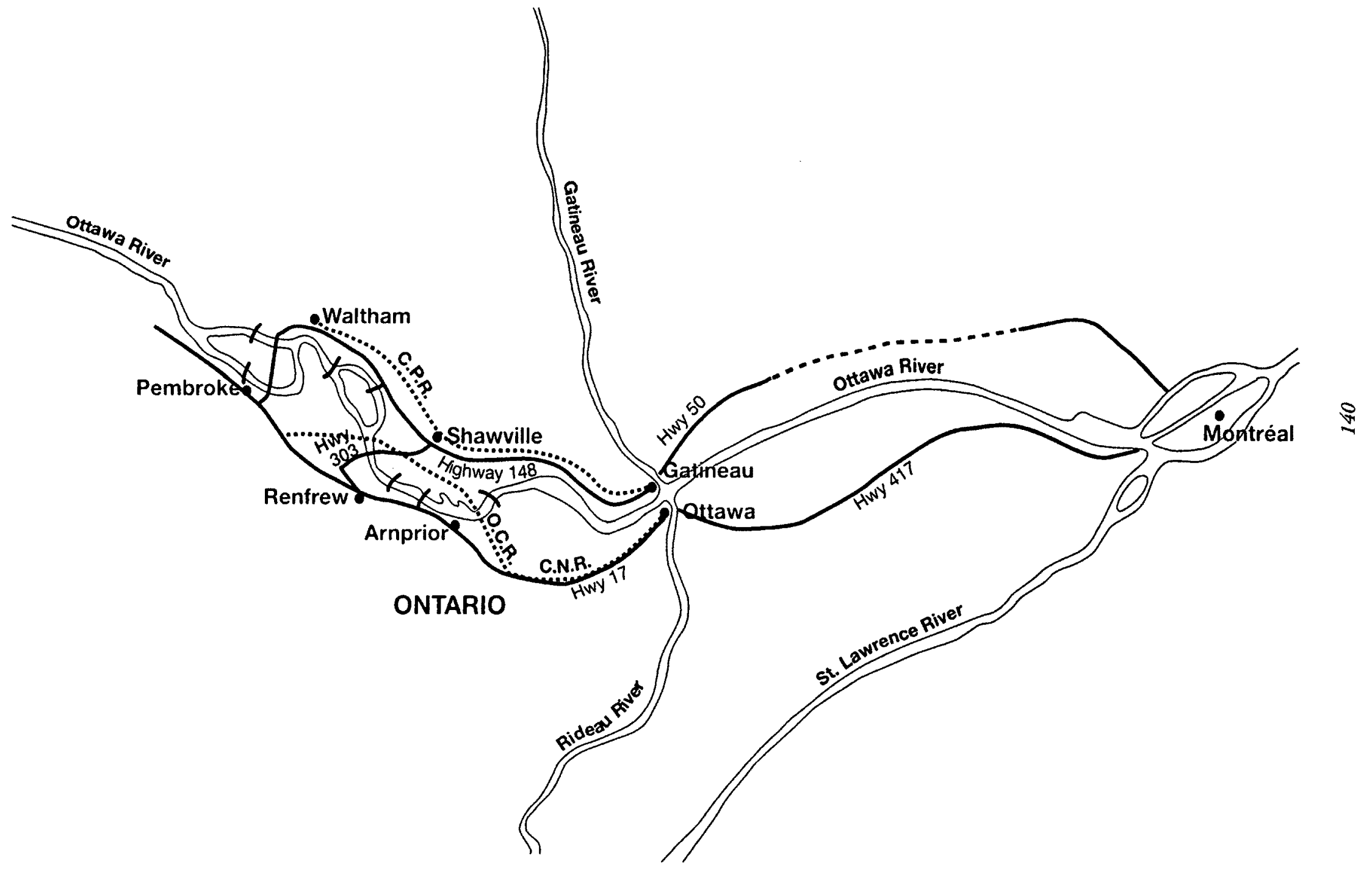


Arnprior bricks, and people travelled back and forth across the river for picnics, socials, and sporting events (Graham 1994:77). The "idea" of the Ottawa Valley that Frigon described has a sound basis in practice. Graham reports that "at least ten ferries operated on the Ottawa between Onslow and Rapides-des-Joachims [locally pronounced 'the Swisha'] in the late nineteenth century" (Graham 2000:23). This change in the pattern of river traffic weakened relationships up and down stream, while it strengthened ties across the river, cross-sectioning the Ottawa River valley.

The Pontiac's physical isolation from the world beyond 'the Valley' was exacerbated by the very railway that was meant to resolve it. The PPJ's promoters pushed the rails inland and as far up the valley as they could, afraid that if the rails got too close to the river they would cross to the Ontario side prematurely. Their goal was to link the Pontiac to the trans-Canada line in both Ottawa and Pembroke, meaning that the region would become central to crossCanada rail traffic. The construction of the Alexandra Bridge into Ottawa bankrupted the PPJ, and brought the tracks westward to an abrupt end near Waltham. The promise of becoming a central link in cross-Canada rail traffic was never realized. Instead, the Pontiac's peripheral status was confirmed when the first trans-Canada highway was built along the Ottawa River on the South shore following the CPR line across Ontario.

The railway was one contributor to "writing" the region as a dead end. By failing to connect back into the regular flow of trans-Canada traffic the railway pushed the area onto a side rail, aggravating the natural boundaries of the river and hills. No one passes through the Pontiac on the way to somewhere else. It is rarely an accidental 'find' or a brief stop en route to a destination up the line. The region's roads have done little better in answering the mobility challenge. Highway \#148 was paved as far as Shawville in 1951 but pavement did not resolve all its shortcomings (Graham 2000:51). The Women's Institute members report that many of 
their "city" friends refuse to drive up "the Québec side" when they come to visit. They cross the hydro dam over the Ottawa River at Chenaux, or come across on the ferry if they can. One of my interviewees expressed enormous frustration with the state of the road (Québec Highway \#148): "The road is still crappy - oh Jesus that road to Ottawa's awful, it's like a barricade. There are so many people in Ottawa afraid to come up this way because they just think the road is bad out of Aylmer". Ironically, the summer following that interview (summer 2011) the highway became a barricade in all but name. A flash flood in mid-June washed out a culvert near Luskville, creating a hole 60 feet deep by sweeping the highway, tarmac and all, into the adjacent ravine. Québec's Ministry of Transportation reopened the highway just days before the Shawville Fair on Labour Day Weekend. By then the barricade, alternating one-way traffic around a five kilometer detour, had been in place for more than nine weeks.

The question of roads surfaced in other contexts as well. The cost of shipping produce to markets or processing plants, "Half the profit's lost in the cost of transportation" (Dan); the cost of the roads themselves "With $270 \mathrm{~km}$ of roads in his township [Clarendon], nearly $2 \mathrm{~km}$ per resident, roads are a big deal" involving snow clearing, pothole filling, wash out fixing, and beaver dam removal (Jack). Even within the region, mobility is costly and time consuming, and yet Shawville is no more than seventy kilometers from Ottawa-Gatineau. Its 'distant' location is, as Brodie describes, the cumulative product of decisions and actions and attitude. It is certainly not a simple question of kilometres.

I don't get it that it's not economically much better off. It's so close to Ottawa, and it's absolutely beautiful... I mean we're so close to Ottawa but nothing falls this way. Nothing seems to benefit the region and I just don't get it. I cannot figure out, I cannot pinpoint. I mean that road thing, okay that's one thing, but now without the roads, why aren't we just a huge service industry for Ottawa somehow? I just don't get why this place isn't like a little gold mine, just something better than what it is. It deserves better, it warrants better, and hopefully in the next twenty years something different will happen.

(Heather-newspaper publisher) 
Despire the frustration Heather (a believer in progress) expressed above, I argue that not having become "just a huge service industry for Ottawa" has saved Shawville from the fate of what Troughton calls "rural-urban fringe zones" many of which, although they have experienced dramatic growth, have also seen the "decline of erstwhile rural activity and communities" (Troughton 1995:295). They have been transformed from particular placel communities into generic semi- and sub-urban space. The growth of such spaces represents a sort of death by assimilation for the communities they absorb. ${ }^{74}$ In resilience terms transformation is emphatically not adaptation, it means that the system has changed its state. In the resilience theory model such a community has "jumped" into a new resilience basin. I argue that Shawville's particularity has been safeguarded by a combination of attitude and accident that has encouraged the community's "tightness" and obscured its proximity to Canada's 'National Capital Region'. Its particularity has, in turn, protected its resilience.

\section{The Particular Value of Going Slowly}

I have described Shawville's political economy in terms of cyclical and contingent employment, the important role of a tightly woven social network, and the region's relative isolation as the product of both mobility issues and socio-political factors. The predictable result of these features collectively is low and slow economic growth. Slow growth has moderated the rate of change experienced in Shawville such that many of my interviewees responded to questions about what change they had experienced by pointing to social and/or political changes at the provincial, national or world scale: Québec's language laws, the shift from religion-based school boards, a general decline in the role of religion. When pushed to articulate change in terms of

74 Like "the Indian" in Thomas King's quip, who must choose between death by dying or death by assimilation. Also like King's "Indian", rural space can be thought about as more real as an imagined ideal than as an experienced reality. "... how can something that has never existed - the Indian - have form and power while somerhing that is alive and kicking - Indians - are invisible?" (King 2004:53). 
their own direct experience in Shawville many of them asserted instead the absence of change:

The people here are people who have been here for generations, and the people that come back, well, It's... an older community. It's comfort I guess, it's a comfort zone for them.

(Dorothy)

That's why this whole village appeals to me, because nothing changes, I mean very little changes and it kind of suits my temperament I think.

I haven't seen huge changes. When I came up here in '76 Pontiac was poor... I thought when the mill closed down in 2008 that we were all going to die, particularly people in business. So that was a huge change which increased the unemployment probably dramatically from when I came here in ' 76 , but no... no, I think it's just the same old Pontiac.

(Heather)

Karl Polanyi (2001[1944]) studied England's transformation from an agrarian to an industrial economy. What he learned about the social upheaval precipitated by the Industrial Revolution led him to conclude that "the rate of change is often of no less importance than the direction of the change itself" (Polanyi 2001:39). His observations caution that "[r]apid transformation destroys old coping mechanisms, old safety nets, while it creates new demands, before new coping mechanisms are developed"... the failure of these social coping mechanisms" contributes to social erosion (2001:xi-xii emphasis original). Without time to reposition itself within its equilibrium basin, a community will find it harder and harder to keep its balance as change happens faster and faster. The image reminds me of a figure skater I heard explain to the media after falling in her long programme, "the elements just kept coming, and I couldn't get my feet under me". Polanyi insists that the resistance to the industrial capitalists that was mounted by "the landlords of England" gave England's political institutions (and its increasingly displaced peasants) time to get their feet back under them. The effect of the power struggle between crown and capital (however inadvertent) was to block "the onrush of the Industrial Revolution" 
allowing "time for almost complete readjustment" (Polanyi 2001:173). Polanyi recognized that it takes time to acknowledge the new demands of a changed set of ground rules and set up the new coping mechanisms demanded by disruptive change. He implies, rather dramatically, that had the creation of a landless labour class proceeded any faster there would have been no labour class to work in England's new factories, only "social catastrophe" and "dislocation" (Polanyi 2001:79). The rate of change can have a profound impact on how smoothly the change can be absorbed. It can make the difference between resilience and the failure of resilience, the change of state into a new form of 'being', or extinction.

I was led back to Polanyi's ideas by one of my Shawville interviews. In that interview my interlocutor, John, a doctor practicing in Shawville, reframed a question about the changes he had experienced since moving to Shawville (nearly thirty years ago) to address instead what he saw to be the changing character of change itself. He maintained that the changes Shawville is currently experiencing are fundamentally different from the sort of change the community has faced in the past.

Some of its traditional enemies are probably less of a threat than they were, and some new enemies are probably a bigger threat than anything ever was, and that's the economic situation more than anything. I think the ability to maintain a rural farmer's lifestyle, or work in the bush, or not have to worry too much about higher education because you can make a go of it in your own community... that's harder and harder as time goes on. And I think, when you enlarge your economic horizons you bring in other elements to the community and you dilute some of its original sense of itself and... so I think that's the major [threat].

The new threats posed by the current economy and its globalized horizons, were, he felt, held temporarily at bay by Shawville's economic depression. If "economics is the engine of acceleration", he argued, "being economically strapped [has meant that] change hasn't happened as quickly as it might have". John pointed to Stowe, Vermont, as an example of 
a community overtaken by change driven by what he called "an overheated, tourist-fuelled economy". In contrast to the situation in Stowe, he reflected,

Café 349 is the only place in Shawville that caters to something that is not local in its conception. It's not like Stowe where people consciously plan things that people from outside the region would appreciate having when they come... there's never been much of a sense that that was important to do... so that when new things come along I think it's, for people who promote them, it's a frustrating thing... decisions in many cases are made in the parking lot... yeah, beforehand. And as I was saying earlier, my initial reaction early on in coming to this community might have been more negative than it is now about that way of doing things... if the whole thing had been amalgamated and a community planner brought in from Toronto and the whole town laid out and all of this stuff changed it would be a completely different place then it is, and I think some of the people are not malicious in their obstructiveness, as opposed to sort of having a gut feeling that they need to understand it better before they'll go along with it, and understanding it better sort of means seeing how it fits with what the character of the community is.

(John)

Mitchell and de Waal (2009) describe the evolution of St. Jacobs, a small Mennonite community in Southern Ontario, from a particular place/community to a tourist-focused "heritage-scape", and eventually to a "homogenized leisure-scape" (Mitchell and de Waal 2009:165). In keeping with Lefebvre (1991) and Clement (1997) above, who argue that each new mode of production entails a re-writing of space, Mitchell and de Waal observe that St. Jacobs' transitioning landscapes emerged in step with new economic "rationales" (2009:157). The construction of a Mennonite bakery, a restaurant, and a furniture factory in the 1970 s, responding to visitors who were drawn to St. Jacobs by the town's unique character, became, by 1990,100 new downtown businesses, a retail mall on the town's outskirts, and crowds of tourists (Mitchell and de Waal 2009:159). Twenty years later (2009) St. Jacobs received 1.5 million visitors. Many of the town's historic buildings had been replaced by ubiquitous chain stores, and few visitors were conscious of visiting St. Jacobs as distinct from any other shopping and entertainment destination (Mitchell and de Waal 2009:161). The new leisure- 
scape landscape has erased all trace of the community's particularity. Interestingly, Mitchell and de Wall report that the changes being made to St. Jacobs incited less resistance on the part of residents over time. They suggest that the growing acceptance could be due to the resolution of some early concerns on the part of residents (parking etc.), but also offer the more plausible explanation that those most distressed by the changes (i.e. those most identified with the community's particularity) may have actually moved away (2009:161). In terms of thinking about resilience this latter possibility is instructive. If the landscape itself has "undergo[ne] an identity change" (2009:163), and the community most invested in that place has moved on there is little left of the particular place/community that was St Jacobs aside from its name. The remaking of St Jacobs as a leisurescape is not a form of resilience but a change of state in which the original 'being' has been lost.

The impact on particular place/communities of the changed and changing rural landscapes is also the focus of Greg Halseth's work (1998). Like Bell, whose ideas we encountered above, Halseth points to the bifurcated personality of rural space as both lived-in (material) space and nostalgic or recreational (imagined) space. Halseth points to the reality of "competing geographical imaginations" in writing about what he calls "the rural-recreational countryside" (1998:226). He looks at the conversion of holiday homes into retirement homes and considers what these conversions mean within the local community. The specific scenario he addresses has echoes in and around Shawville where summer visitors are a significant presence, and a growing number of those visitors stay to swell the number of resident retirees.

There was wide consensus among the people I interviewed that "retirement" is Shawville's current "industry". Agriculture, forestry, mining and various enterprises derived from these extractive industries have supported Shawville's economy in the past, but retirees and their pensions are Shawville's current economic base. Bill and June (who retired from teaching in 
the local schools) were the first to point out to me the seemingly odd concurrence of fewer jobs and a growing number of cafés and restaurants - evidence of people with both time and money to spend. In another interview Robert answered the question, "what is it that supports the community these days?" with little hesitation. "Retirement", he said, "although the demographics are against that in the long haul. Children are being bussed into Shawville, and outlying communities aren't in great shape either. I can't imagine what anyone's doing [out] there now".

Dorothy, a retired (local) teacher herself, also pointed to the growing number of retirees in her community.

The number of widows that maintain homes in Shawville is unbelievable... that's what the base of Shawville is... it's retired farmers, or people who retired from the Mill, or some people who retired and returned back to Shawville. Norway Bay [in the 1970s] was not what it is now. There are far more permanent residents than when we first moved here...there are a lot of retirees here now. Its cottage country... and the people that have come to retire here they come from Ottawa and urban areas and they love it. They love the quiet... and they love the friendliness of the businesses around here... Some of the people here in Norway Bay wish there were more restaurants. There's no restaurant here at all [in Norway Bay]. It's true, all these people that are living here now have more needs as well.

(Dorothy)

Pointing out that the region's biggest employer these days are the hospital, and the schools, Dorothy went on to estimate that fifty per cent of the hospital staff and school teachers drive up from Gatineau or Ottawa every day. These new professionals do not live and raise their families in the community. "You don't really hear of a family moving to Shawille", she observed,

... the big thing that I found is there's not as many professionals here now, when the Mill was operating, the Mine, there were more professionals. Hydro Québec. When the Mill came in they built that subdivision up in Shawville. That brought a lot of revenue into Shawville, and that's gone now. There's not nearly the same number of businesses. I don't think there are. There's Hursty's, the Café, but there used to 
be other restaurants. There used to be Fraser's [Men's Wear]. At one time there was a theatre in Shawville (where Eade's Carpets was), and a dairy (now Murray's). I remember going to the dairy as a kid. The businesses have closed; just over time and because there are fewer and fewer employers. When the Mill was there all those businesses on Main St. did well. When the Mine, Telebec, Hydro, the Mill closed they just had to go [the unemployed]. I guess with Hydro some of them retired.

(Dorothy)

There is plenty of anecdotal evidence to support Dorothy's observations. There are also some numbers (see graph on page 150). While the overall population of Shawville remains very stable over the thirty six years the graph covers, the number of people over sixty-five, and the median age of the population, rise steadily. The overall number is held constant by the arrival or return of retirees to replace those leaving for work or school. In a February 2011 article in The Equity, the warden of Pontiac MRC, Mike McCrank, points to rising property values in the area as "a telltale sign that the boomers are fuelling the increase in population in the Pontiac". Just as Dorothy observed, "[They] are coming in and buying land and cottages and turning them into residences" (The Equity 02/02/11:3).

It is not demographics but current political and economic trends that pose a threat to Shawville's financial reliance on returning retirees. If it were simply a question of "demographics" the passing of one generation of retirees would be seamlessly countered by a new generation of people retiring. The alarming part of this equation is that given the current economic climate and the trend toward freezing or undoing benefits and pensions there might not be another generation of pensioned retirees. There is some question as to whether people will be free to return home without company pensions, never mind having sufficient means to enjoy the local cafés and keep local businesses afloat. There is no shortage of aging people, but secure and comfortable pensions are fast becoming a rarity. ${ }^{75} \mathrm{I}$ am not convinced

75 There is a thorough discussion of the increasing precariousness of work in Canada in Clement and Shalla's book Work in Tumultuous Times (2007). 
Population and age structure in Shawville, Québec 1996-2006

\begin{tabular}{|l|l|l|l|l|l|}
\hline Date & Population & $\begin{array}{l}\text { Percentage } \\
\text { over 15 years }\end{array}$ & $\begin{array}{c}\text { Median } \\
\text { age }\end{array}$ & $\begin{array}{l}\text { Number over } \\
65 \text { years }\end{array}$ & $\begin{array}{c}\text { Number } \\
\text { over 75 } \\
\text { years }\end{array}$ \\
\hline 2006 & 1,587 & 84.2 & 49.4 & 495 & 285 \\
\hline 2001 & 1,582 & 83.2 & 45.4 & 395 & 270 \\
\hline 1996 & 1,632 & 81.9 & 43.8 & 450 & 250 \\
\hline 1991 & 1,591 & & & 450 & 235 \\
\hline 1986 & 1,575 & 82.9 & & & \\
\hline 1981 & & & & 370 & $n / a$ \\
\hline 1976 & 1,724 & & & & \\
\hline 1967 & 1,534 & & & & \\
\hline
\end{tabular}

(Statistics Canada) 
that people living on government "old age security" will offer the same economic benefit to the communities they retire to as retired professionals drawing company pensions have been able to provide. I am not even convinced that without secure pensions people will be able to move away from the greater possibility of on-going part-time employment where they are already established.

There are other factors in the trend to winterize summer homes that carry their own complications. The newly permanent residents in once summer-communities like nearby Norway Bay have impacted the Shawville community in a variety of ways. Converting cottages into year round homes has driven up the value of local real estate. An aging population has begun to change the focus and priorities of service providers and community advocates. As Halseth's research shows, the texture and character of the community will be impacted as much by who lives here (their ages, needs and interests) as by how many live here (the tax base, volunteer pool, and political clout) (1998:113). A further implication of being an aging community is being 'seen' as an aging community. There is a real possibility that being overtly associated with retirement will reinforce the tendency of urban-focused policy makers to dismiss rural needs as passé and passing. We have already considered the implicit linking of farms to the pre-modern past. A growing population of retirees risks strengthening the impression among urban-based policy makers that rural space is no longer productive space.

Land has been cheap in the Pontiac. Inexpensive land has meant affordable mortgages and low rents, deflating the cost of living here. ${ }^{76}$ For many the frustrations of travelling back and forth to Ottawa for work have been offset by the advantages of an Ottawa salary and

76 The Equity May 7 2008, p.1. The headline story is part of a series interpreting Statistics Canada's 2006 findings. This article explains that despite very low employment and income figures, Pontiackers are no worse off than average - their economic woes "offset by significantly lower housing expenses". The Equity's reporter cites average local mortgage payments as $\$ 376 /$ month compared to $\$ 717 / \mathrm{month}$ as the average across Québec. 
a Shawville mortgage. The comparatively low cost of local housing has been an obvious advantage in times of unemployment. The increasing value of real estate driven by both property improvement and increased market demand will make it harder for young families to choose to stay, and harder for retirees with more restricted pension incomes to come home. A higher resale value for local properties might even have the unhelpful effect of contributing to outward mobility, particularly among youth and working families who will no longer be able to justify the time and expense of 'travelling' to work by the savings they can realize in housing costs.

Halseth observed that empty-nesters setting themselves up for retirement in their erstwhile cottages drive a shift in the kinds of institutions and events the surrounding community supports. As he says, youth focused activity clubs give way to "card game and bingo afternoons" (Halseth 1998:113). There must be a critical mass of young families to support services like drop in centres and day cares. A certain number of local kids are needed to make a youth centre viable. Where there are limited resources (and resources are always limited) time and space and funding will go where need and numbers (or political expediency) most warrant.

Shawville's median age climbed from of 43.8 in 1996 and 49.4 in 2006, to 50.8 in 2011 (compared to Canada wide median age statistics - 35.3 in'96/38.8 in’06/39.9 in'11). The impact of more seniors and fewer children can already be seen in both of Shawville's schools. The vice-principal of Pontiac High School reported that $95 \%$ of her students are bussed in from a catchment area with a 45 kilometre radius. Few of the school's students actually live in Shawville. Dr. S.E. McDowell Elementary School sustained a 35\% drop in the number of elementary school students over the past decade (from 376 in 1999/2000 to 241 in 2010/20111). If, as Halseth's research predicts, community resources focus on caring for those who are here, there will over time be fewer resources available to support or appeal to a 
shrinking and/or absent population of families and young professionals. A community needs to be supported by institutions, services and activities. These, in turn, require a critical mass of participants for their support. As Rudin acknowledged, there is a tipping point after which a community's decline is inevitable (1985:289). The small number of children (representing working families) living in town, and the decreasing numbers in the surrounding region, have serious implications for Shawville's future resilience. ${ }^{77}$

It is important to note here that Shawville is far from abandoning hope of drawing new families. As a community Shawville generously supports school initiatives, the hockey and figure skating clubs, and built a new "splash pad" in the public park in the summer of $2011 .^{78}$ There are on-going efforts to attract new industries and prospective employers to the area, including a proposal to re-develop of the closed saw mill property and re-open rail service to the site. The current picture is one of "business as usual". When I broached the question of what a declining local population might mean for their future with the youngest couple in my sample they were quick to concede that bigger farms made fewer neighbours inevitable. They had no answer to the way falling numbers would impact schools and shops and the other kinds of infrastructure needed to support a community. They didn't really want to consider the future of current trends at all. "At the same time", Jared countered optimistically, "there will always be people whose hearts are here".

The value of being connected to family and "home" was specifically affirmed in every one of the interviews I conducted. "Shawville is a great place to be from, and to come back to", declared Pearl (nonagenarian) pithily summarizing Shawville's strong centripetal pull.

77 Just last week (October 3, 2012) the West Québec School Board notified parents that it is considering moving Dr. S.E. McDowell students to the high school and closing the elementary school building. There are now 214 students.

78 I was present at the Town Council meetings when these projects were approved. Fall 2010. 
And of course when you get old and retire you come back and Shawville is full of... I've got many retired people who live on a pension, a company pension, or the old age pension, or... so it is a nice place to live but it doesn't have industry to hold young people. People do move a lot. A lot of people go down to Ottawa, across to Renfrew. You hear about the bridge, you know, the traffic being bad or good on the bridge, and that's taking our people to Ottawa to work. The Champlain Bridge I mean... Of course, I always say Shawville is a great place to come from. Because at the archives we get people from British Columbia, any place across the country, down the States, over in Europe sometimes, and they're coming to look for their ancestors, telling us who they're related to you know, but even, and this is from when I was younger, you'd go to Toronto and you'd say something about Shawville and they'd say, "Oh, do you know anybody in Shawville?" the word kind of stuck out because they knew somebody from Shawville. I suppose all towns are like that, but I guess it's a nice seeding place...

The existence of Shawville's compelling "zone of attraction" attests to the presence of a coherent core. 'Being Shawville' means something, however un-definable and indefinite that something remains. The following extract from my interview with John expresses something of what that core might include:

The thing that is attractive about [Shawville] is that it's very proud of its existence. It's not particularly apologetic about the things that make it different from other communities which ah... make it in some ways that you have to know all the codes to really fit in but that it has some sort of internal consistency to it which... which is durable over time. And I even see it in the kids you know, who were toddlers and quite a number of whom have stayed around, in contrast to the typical thing where all the kids leave, and they are, you know, very much in the mold of their parents, many of them that I see... and... the kids who become Miss Shawville Fair and who accept that it's part of what living in Shawville is about and it gets modulated with time but it doesn't... It's still very much the same I think as it was when their grandmother was Miss Shawville Fair... and I find that over time... it's very easy in the early years to kind of dismiss that if it's not part of your own personal experience. I find I have more respect for it as time goes on... partly because of its durability. I think it's to the credit of any community to have a sense of itself and it's always sad when that community loses that sense of itself. 
John's choice of words leaves plenty of room for movement within the adaptive cycle. He acknowledges the enactment and re-enactment of collective identity as a performance guided by a contested script and set against changing external constraints. Being Shawville is never quite the same in any performance, but there is something predictable and reliable at the core of the performance that people recognize and want to return to.

Shawville's self-confident performance of itself has not translated into the sort of "branding" power Markey et al. would advocate, or the "heritage scape" Mitchell and de Waal describe. John described attending recruitment fairs where small communities actively promote themselves to medical practitioners hoping to entice them to live and work in their small towns. He told me that, "Shawville's never jumped on that band wagon at all... We still have all of these little municipalities that resist things more that they embrace change. It's a protection of something, I don't know how well defined the something is, but I don't think it's perceived as being 'so bad' or in need of change".

Feeling satisfied with what you have is widely interpreted by a worldview bent on growth as a lack of drive or worse. ${ }^{79}$ The failure to embrace and even to seek out change is rarely understood as a simple expression of contentment. The whole idea of being content runs contrary to the world Thomas Friedman describes as "flat" and full of opportunities, where, "when the sun comes up, you better start running" (2007:137), or risk being left behind. For the past half century or so, being left behind has enhanced Shawville's particularity and contributed to protecting the community's resilience.

79 While my brother was working for World University Services Canada (WUSC) in Nepal he wrote in a letter home that "all development is built on the destruction of cultures of sufficiency". The statement expresses his own disillusionment with the effects of the work he was there to do. He felt complicit in destabilizing a pre-existent sense of what was "enough" and instilling in its place dissatisfaction and a hunger for "more". 


\section{Conclusions}

Being 'left behind' economically and socially has given Shawville time to adjust to and even assimilate the change it has experienced in recent decades. John, who pointed to the changing nature of change, argued convincingly that Shawville has not yet reached a moment of crisis because, "by virtue of being economically deprived... change hasn't happened as quickly as it might have". Several of the Shawville residents I interviewed argued that very little had changed at all within their experience. Some change has been slow enough to be imperceptible, slow enough to have been appropriated into the experience of "being Shawville" so seamlessly that the performance has continued without a visible interruption.

Shawville's resilience, examined through the lens of political economy, challenges many of the taken-for-granted truths of a growth-focused economy, and the political institutions that support it. Most significantly, the situations and effects that maintain Shawville qua Shawville run counter to the commonly accepted imperative of growth itself. Resilience, the ability to absorb changing circumstances and destabilizing events without "jumping" to a different state of being, is not about growth, or progress, or ever-rising expectations. It has been strengthened in Shawville's case by a measure of isolation from core political and economic drivers. It has been protected by opportunities to put useful skills to work independent of "jobs" and "wages". It has been shielded by a rate of change slow enough to allow time for adjustment and accommodation. Shawville's resilience has counted on an ethic of independence and interdependence born of the community's experiences and the stories in which they frame them.

In Chapter Five we turn the collide-o-scope lens to an examination of Shawville's identity to consider the contribution of the community's deep and interwoven roots to the strength and resilience of this particular place/community. 


\section{Chapter Five: Identity - Interconnection, Continuity and Story}

\section{Introduction}

In this chapter the 'slide' under the collide-o-scope lens pulls together a variety of factors, historic and contemporary, that contribute to Shawville's identity and its status as a particular place/community. The first section presents a quick sketch of the community of people as it is perceived by those who know and constitute Shawville. The discussion focuses on the community's self-identification as distinct and affirms the resiliency inherent in that sense of distinction. The next section explores the community's history and the relationship between where Shawville's "original" families came from and the character of the community they have become together in this particular place, touching on the complex implications of affirming a British-Isles origin 'ethnicity' as a distinguishing characteristic given the community's particular situation in francophone Québec and multicultural Canada. The chapter then turns to a more theoretical consideration of community identity, considering the importance of particularity in the role of a place/community as a site of meaningmaking, and the importance of a distinct identity to the work of building and maintaining community resilience. This examination of Shawville's collective identity is motivated by the question, "What role does this community's identity play in supporting its resilience"? How does 'who' Shawville is contribute to the scaffolding that supports this particular performance of being Shawville?

Exploring Shawville's resilience through the lens of identity adds a further dimension to the resilience theory model I have been using to investigate Shawville's persistence as a community. Deep roots and long-running connections give the community's resilience 
depth: deep footings on which to stabilize the present, a deep well of story from which to construct meaning, and a deep investment in this particular place/community that is not easily surrendered. Its well-seated and durable foundation has played a considerable role in Shawville's will and ability to persevere qua Shawville. As I showed in previous chapters the community is protected from "jumping" to a new state of being as something other than itself by a compelling zone of attraction and an experienced boundary, created and maintained by the community's certainty of its own distinctness. I presented evidence of Shawville's dynamic centripetal force and well-defined resilience basin being supported by both geographic and politico-economic factors. Now I turn to the role its particular identity has played in reinforcing Shawville's resilience.

\section{Who is Shawville?}

To ask about the identity of a community within the discourse of the social sciences begs several questions before the conversation can properly begin. Identity and community are both among a group of terms under censure, or, at least, careful scrutiny within the academy. Accused of being both too 'hard' (essentializing) and too 'soff' (indefinite and therefore useless as an analytical category) such terms require careful definitions and repeated caveats to gain their credentials in academic discourse (Brubaker and Cooper 2000:11). Handler (1994), for example, cautions that we (academics) should be as suspicious of 'identity' as of all other "reifying conceptions" (1994:27). He places 'identity' (particularly in reference to the especially fraught idea of collective identity) in a category with words like culture, nation, and tradition which, although they are ideas, are conceptualized as things because they are expressed as nouns. As 'things' these ideas are inevitably simplified and discussed as if they were "bounded, continuous and homogeneous" rather than contested, fluid and contingent (Handler 1988:6). Because nouns name 'things', according to this argument, the speaker/listener hearing the 
nouns identity or community 'forgets' that these 'things' are abstractions and cannot but flatten out all the complexity and nuance of his or her own experience with lived identities (selfascribed and imposed) within lived communities (nested and juxtaposed).

Although I am, in this context, contesting Handler's insistence that to express terms like identity and community as if they were 'things' is to limit them, I am entirely convinced by his argument that it is helpful to think about such nouns as verbs - to ask what they do, how they do it, why, and what is at stake. These are important questions. My point here is that his argument assumes we give no value to the proof of our own experience and senses. While his assumption is perhaps all too true within academia, surely it need not be. We (academics) are capable of carrying our prior knowledge of experienced communities into our conceptualizations of them. There is no need to 'forget' what we know of their complexity. ${ }^{80}$

Dorothy Smith, for example, challenges the fictive 'Archimedean' standpoint too often assumed by social scientific discourse because it puts both reader and writer "outside" their "own actual situations" and effectively negates experience as knowledge, or disqualifies as "not knowledge... their own good knowledge of the practicalities and organization of their everyday and everynight worlds" (1989:39). As Cohen writes, the word community is "bandied around in ordinary, everyday speech, apparently readily intelligible to speaker and listener" but "causes immense difficulty... when imported into the discourse of social science" (1985:11). I will readily acknowledge that the ideas 'identity' and 'community' are as difficult to define as the experience of them is to articulate. Nevertheless, we can draw on our shared and disparate "good knowledge" of contested, contingent and nonetheless experienced-as-real communities and identities to inform our interpretation of who and what Shawville 'is' according to those who experience and constitute that community and its identity.

80 The discussion returns to Handler's ideas toward the end of this chapter. 


\section{A Character Sketch}

I find the little village of Shawville to be very friendly, as far as my neighbours are... my little community, on my street, stays mostly the same. So I get along well with all my neighbours and it's a quiet place... I know a great many [people]. But it's amazing to me when people say, "now, which street does this person live on"? I say, "I don't know, but you tell me who lives near them and I can tell you for to find them". We got street numbers well maybe fifteen years ago but I still don't know the streets. I just know the people, where they live.

(Pearl-nonagenarian/museum volunteer)

It's a small town with a wonderful hospital, and wonderful archives which gives me lots to do and gives me security and it has nice little stores where I'm comfortable shopping, and a Giant Tiger with good prices, and a Stedmans with all the things that I like to buy and a Dollar Store where I can get wonderful bargains, and an art gallery and a library and friendly people... I have a nice walk every day to the archives, and to the mail, or to the hospital. So it's got everything I need.

(Venetia-story teller/archivist)

We're all quite proud of where we live. I know I'm very very proud of the Pontiac and not only for agriculture. For sure I'm from here, my roots are here now. My kids are here. My everything's here. All my buddies in Ottawa know that I'm here now. I'm happier here than anywhere else. I was so fortunate that I went to Ottawa for high school but I went to elementary school up here and that was all well and good, and now I'm raising my kids up here and I'm extremely proud that they're going to be good Pontiac lads, and maybe a Pontiac lass.

(Dan-farmer/new dad)

Pride is one of Shawville's overarching character traits. It comes through clearly in Albert Armstrong's well-rehearsed recitation of his family lineage below:

My dad's father and his grandfather started the brick factory in Shawville which now is known as the Armstrong Heritage Farm. Most of the brick houses that you see in Shawville now were built from the brick of the Armstrong Heritage Farm, and most were built by my great grandfather, Samuel Armstrong, and by my grandfather, Wellington Armstrong, and by my dad, Elgar Armstrong. We kind of have a mark, a place in the municipality because of the brick works... [I]n the early years when the municipality of Shawville was built, people came as great tradesmen, people from Ireland, most from Ireland - some from Scotland later on, but most from Ireland. And they brought their trades here with them. Great tradespeople who had pride 
in making sure their work was done properly. They weren't looking for the speed of the work. They were making sure these homes were going to be here for many generations. And so they are.

Shawville also claims distinctness as a defining trait. It is so much a part of Shawville's projected self-image that someone from a neighbouring community told me Shawville behaved as "a nation-state unto itself". All of the interviewees used the word distinctive to describe their community, legitimising their claim to distinction by citing Shawville's "Englishness" within French Québec, its Protestant character in a Roman Catholic province (there was little acknowledgement of Québec's post-1960s secularization), and its autoreferential status as a rural community that is not within the orbit of any larger urban or semi-urban centre.

Many of my interlocutors specifically insisted on 'determined' as a defining characteristic of their community and the individuals within it. Margaret (retired teacher/ farmer) in particular had been following my columns in the local paper closely and began our interview with her own reflection on the source of Shawville's resilience.

I started reading [the columns]... I've been trying to analyse and I truly believe that it is our ancestors who came to the country and worked so diligently, that this is where the residents or the population of Shawville have acquired this resilience as you, as you call it. Because we look back at our parents, or grandparents, or great grandparents and we see how hard they worked for this country and its almost like you don't want to let them down, and perhaps a lot of the ummm, the religious side too. We're a people committed, determined.

(Margaret)

Margaret characterized "her people" as people who take commitment and responsibility seriously. Later in the interview, she told me about the time her husband lost his cane out of the cab of his combine. He had recently undergone double hip replacement surgery but 
was feeling restless and wanted to get back to work so he'd climbed up into the cab. When his cane fell he was stuck. He couldn't climb down again unaided. She finished the anecdote asking, "So do you think we're determined?" Her people's determination, their ability to "dig their heels in and really rally together" shone as a badge of honour. Her anecdote, an apt illustration of a particular sense of self, describes a personality more intent on "making do" whatever constraints life has handed it then in settling for "making do" without. It is a personality willing to find humour in its own predicament as long as it also means there's a story to tell when it's over.

Other interviewees described Shawville's independence. John, you will remember, credited the community with "a sense of autonomy,

a sense that nobody is going to do it for us so we have to do it for ourselves... a sense that, well, it's probably better that way, that we're in charge of our own destiny... I think that a community characteristic is that they don't panic very easily. They take care of business and have a good deal of self-confidence that there aren't too many problems that are beyond them.

(John-physician)

I'd say the community is very 'tight' - mainly because of their - I don't want to say backlash because that's not the right word, but being an English community in the Province of Québec right now isn't maybe the easiest thing in the world. You almost feel like you have, you're backed into the corner, but you have your neighbours with you so you work together... [you don't] assume that's supposed to come down from the province, or the nation, or the department of whoever-looks-after-that,... here they say, "well we're not going to get it from them because we're little Shawville", or "we're the English ones", so we're not gonna get our MRI or whatever it happens to be, so we're gonna fight, and we're gonna show them, go arm in arm and raise the money. So that's why I say it's kind of tight.

One side-effect of the "tightness" expressed in the last excerpt is a tendency to be insular; another is a reluctance to embrace innovation. Dan, the farmers' advocate who called the 
community "tight", excused both traits, observing that a community that is on the defensive is bound to feel defensive about adopting new ways of doing things. "[T]hey feel they have to protect what's been theirs", he explained, "and they want it to still be theirs".

You may remember that Margaret, the self-described Shawville "original", admitted to me that she was very surprised to hear someone who had lived in Shawville for more than 25 years comment "that he did not feel like he was what I would classify as a Shawvillite". She liked to think that her community was more welcoming than his comment implied, but had to conceded that there is a joke within her circle of friends that explains particular behaviour saying, "Oh well, she's a Shawvillite". That if you are an original somehow it's different".

Debra, whom we have also already met, described the community as close and closed, again without conveying a negative judgement of the community on those grounds.

My perspective growing up as a kid living just outside the village was that it was quite a close knit community, and that if you weren't part of the village, you really weren't part of the village. That was my perspective growing up. As a kid I really didn't feel I was part of the village. There were people who lived in Shawville and people who didn't. Now I'm back and actually living in the village, and it's still my perspective to be honest with you. And I don't mean that in necessarily a bad way, but I think there is a distinction between the village of Shawville and perhaps the municipality of Shawville, and certainly a distinction between Shawville and Clarendon. Not just politically, but there seems to be [a distinction] even in people's perception of where people live and how they act. And I don't even know if I can put my finger on it, to be honest with you, it's just a feeling...

(Debra)

There are several recurring themes in these cameos of Shawville. They portray the community's sense of isolation within Québec and the ethic of independence, inter-dependence and determined effort that are part of its self-identification. The snap-shots provide evidence of a clear boundary defining the limits to the community's sense of self and establishing the 
perimeter of its resilience basin, defining the dividing line between this state of being and a new state of being so that it is harder to 'slip' across. The community describes itself as proud, distinct, determined, independent and close-knit, character traits that contribute directly to its resilience by affirming its particularity. As a particular place/community Shawville is both motivated and equipped to reproduce itself as itself, within its current resilience basin.

\section{Protestantism and Englishness}

Another telling of Shawville's story begins with the long-standing conflict between Protestants and Roman Catholics in Ireland. Determined not to import violence along with 'his' Irish settlers, James Prendergast, the first crown land agent for Clarendon (appointed in 1825) decreed that there was no room for Catholics in his Protestant township. The ban was lifted less than ten years later, but the Township's reputation as hostile and unwelcoming to Roman Catholics was already firmly entrenched. Local historian Lloyd Armstrong writes that the Orange Order played a significant role in the life of the community and inevitably served to reinforce religious differences between Clarendon Township and its neighbours (1980:26).

Today, while there are six Protestant congregations in Shawville, there is still no Roman

Catholic Church within the town limits. In the words of one of my informants:

Protestant? Mr Prendergast was Protestant and he decided that he would like, well he had the job of sorting out who would get a lot of land in Clarendon. And a Protestant would come, he would have a list and he would have a lot for them. When a Catholic came along he decided they would go farther up, I don't know how far up the river he would give them lots, but Vinton's not so very far away, and they went there. People use that story to say he didn't like Catholics but in my mind he wouldn't likely tell a Catholic family to settle next to a Protestant family because if they were fighting in Ireland that wouldn't be a good thing to do. So they went up farther to be among their own kind, and he'd send the next Catholic up there. I think that was a kindness and a smart thing to do. 
The relationship between Protestantism and "Englishness" is significant in interpreting Shawville's self-identification. Henry VII, in order to take his stand against the Pope successfully, had to convince the English that they could manage without the Holy Roman Church. As Stevenson writes, convincing the English to accept the loss of Church Sacraments and the risk of ex-communication would have been impossible without first inciting a strong and emotional rejection of Catholicism (2006:28). When Ireland was conquered by the Tudors (Henry and Elizabeth), Protestantism as a badge of English identity was still raw, and the Catholic Irish were made to feel the full weight of English fear and anger (Stevenson 2006:31).

Irish Protestants, many of them "planted" by the English crown to assert English sovereignty, and cultivate the Protestant faith in Ireland were heavily invested in their "Englishness". The Irish men and women who settled in and established Clarendon Township were not the "potato famine" Irish of mid-century, but economic migrants (tradesmen and farmers), de-commissioned British soldiers, and loyal monarchists. For them identity and belonging were deeply tied into their Protestant faith. It is not too big a stretch to suggest that as religion has given way to language as the salient marker of group identification in Québec, the self-identification that was attached to being Protestant now adheres to being English-speaking for this particular community (Oakes and Warren 2007). While all of my interviewees cited "Englishness" as a defining characteristic of their community, the religious divide was much less salient in day to day interaction.

Obviously when you're up at Fort Coulonge it's mostly going to be French. However, as soon as you're attracting clientele from Chapeau or Waltham or something like that you're pretty much back in English territory and you know Shawville is pretty much all English.

(Pat-dietician)

Shawville is Anglophone. Yes, completely. And it doesn't seem to... I don't think that has changed at all. When I was a kid, it was understood that Shawville was the English village and I think that even though there may have been some Francophones 
that have come in, it would be rare to hear French being spoken on the main street.

(Debra - vice principal)

At one point in time Shawville was, going way back into the eighteen... middle eighteen hundreds, the municipality was completely English, so there was no need to be bilingual. Up to 40 years ago, then there were more Francophone people moving into the community, which probably put Shawville at 98\% English, 2\% French. Now we're about $90 \%$ Anglophone, 10\% French. It is changing, and I think people like our community... I didn't always think that way... even after I took the French immersion course, I would say, "why do we have to speak French? Why can't I just speak whatever language that I want to speak?"... and you know, many people around Shawville were the same way. "Hey, we live in Shawville, so we're going to speak English. If you don't speak our language then I guess we don't talk." And I used to think that way. [Now our] office staff here is bilingual, [the council secretary] is totally bilingual, and that's something they didn't have years ago. Up until probably ten years ago the office was English and if you wanted to deal with us then it was English, you know.

(Albert - Shawville Mayor)

In 1998 Québec's Minister of Education reorganized the province’s school system to reflect linguistic rather than confessional alignment. When I asked my interviewees how they had experienced this shift they reported various impacts associated with an on-going struggle over language rights. They cited no particular issues with the move away from religious affiliation. Language has superseded religion as a divisive issue in school board politics, just as it has in daily interactions.

The language is, to us is, more hurtful or bothersome I guess you could say... it's a different feeling than Catholic and Protestant... you can be whatever you like and I wouldn't even ask now. A few people would maybe think of that but as far as I'm concerned it's pretty well, I don't know... it doesn't mean that much anymore to your neighbour if he's Catholic and you're Protestant. We just get along the same. I think that, but that's my feeling anyway. 
Language, in contrast, is something Pearl still experiences as divisive, something people do "ask about" and which can carry a lot of weight. The story of Billy McCleary ${ }^{81}$ and the ice cream sign that I have included below expresses the hurt and frustration the speaker above pointed to, lightened by the sense of humour the story also captures. Pearl told me the story with laughter just below her words:

Well, Billy McCleary is my youngest son. He first graduated from high school and he didn't go to college. He worked at Canadian Tire, but he always wanted to get on at the Consolidated Bathurst Mill (it changed names after). But that was a good job. He had a good insurance policy there. And while he was there he and his brother-inlaw Lee Laframboise decided to buy the Bean's Service Station Garage. They bought it from Keith Bean I believe it was. It was called Bean's Garage, and it's still called Bean's Garage. They did well and they had their sign up at the front and they sold gasoline and they fixed cars and did all the ordinary things that garages do. And then the Québec sign laws came in and they had everything just fine, French and English as was required, but they had a little hand written sign above their ice cream stand (a nice little ice cream stand they kept open in the summer) and it was just written iice cream'. So the language police decided they were going to fix that. So first thing you know there was a letter coming. Both my son Billy McCleary and Lee Laframboise were co-owners, so they each got letters that they must change their sign. So neither of them paid any attention and after a certain time another letter came and they were going to be fined. I'm not sure how many letters came, how many warnings, but Lee Laframboise's wife thought that they were going to be in big trouble if they didn't pay before the fine got too big. So Lee Laframboise paid his share of the fine, or paid his fine and Billy just, Billy McCleary just said well he's not gonna bother with that. And more letters came. He was gonna be fined and it got pretty big, you know. At last they were threatened with seizure of their machines and property so the bailiff came to his door (I've forgotten the date now but it might even be ten years ago) with the order to pay up or have seizure. Billy just said "I'm not paying". So, the Sherriffs sale went ahead and was set for a certain date and that was fine. Billy took them around and showed them all the stuff he had that they could seize if they wanted, his truck and his cars, you know, and his skidoos and he said, "Do you want my wheelbarrow?" So they went away and the date for the sale was set and of course the word got out and Billy has many friends and they weren't all English-speaking either, there were some French-speaking people in Shawville didn't much like that idea either, of a person being fined for a little sign. So there was a great many people decided well, when this sale comes up we're going to bid in this stuff and we're going

81 The Ice cream Sign story is a matter of public record. Bill McCleary himself told it in a letter to the editor which appeared on the editorial page of The Equity July 9 2003. I have reproduced 'Pearl's' telling verbatim in order to convey something of the emotion behind her telling - more amusement than anger. 
to give it back to Billy (that's been tried out West when the banks were foreclosing on farmers and sheep men). Anyway, it was all set and there was a big party planned and it did happen, in the Lion's Hall, and I don't know, just a few days before the sale was to happen word came that "Oh, there's been a clerical mistake". The sale was off. Well I know why the sale was off, because they didn't want the publicity, it was all over town and everyplace else and in the papers what was going to happen. So, Billy was disappointed, he wanted to go through with it. Anyway it didn't happen, but the party went ahead. The Anglo-Quebecker's group lawyer (I should've looked up his name), he came and he talked. They asked Billy to say something, you know, and well, he's a man of few words but he did get up and said a little speech and he thanked the people and all that. And the party went ahead. Now I don't think there was dancing, but I was there and there was a great old crowd upstairs in the Lion's Hall, and a few donations given to the Anglophone rights association. I also sent them one, and I sent them a letter too and I thanked them, and said you know, my son, he's a man of few words (although he did make a speech at the party). "But", I said, "the first speech he made was the best and the shortest when he said "I'm not paying". So anyway the papers had it and they told quite the story about this. I'm a little surprised that they left him alone then, but there never was anything said after that.

(Pearl)

Billy's story, his own quiet refusal to be pushed, his neighbours' plan to undermine the authorities, and the pride and amusement in his mother's (ninety-two year old) voice, speak volumes about Shawville's "identity". It is an anecdote that elegantly captures something of what it is to 'be' Shawville, and illustrates the confidence in its own particularity that has served the community so well. The story of Billy McCleary and the Ice Cream Sign offers a look at Shawville's 'personality' that rounds out our character sketch.

\section{Not Such a Long Way from Tipperary}

Yet another telling of Shawville's genesis story begins with the arrival of John Dale and Thomas Hodgins in 1821. The men, together with Dale's wife and three children travelled up the Ottawa River from Chats Falls (just upriver from Ottawa-Gatineau in terms of present-day geography). While Dale's family safeguarded the party's supplies on a "small sandy beach" just 
below the Cheneaux rapids, the men blazed a trail some six miles inland on the River's north shore. Eventually they came to a "beautiful spring bubbling out of the ground" where Dale decided to build his home. 'Tipperary' Thomas helped Dale and his family to make a start and later returned with his own family to settle a neighbouring piece of land. Claiming to have found a piece of paradise, he wrote letters home to Ireland encouraging his friends and relations to come and claim their share, which many of them did (Armstrong 1980:16-19).

Bruce Elliott has made an extensive study of the settlement patterns of the Tipperary Protestants. His work describes their practice of "chain migration", families following sons or brothers who were already established in Canada and the U.S.A. (Elliott 2004:240). Hodgins' kin settled on both sides of the Ottawa River, in Clarendon Township in Québec, and Goulbourn and Huntley Townships in Ontario. The Ottawa River connected the communities along its shores, creating an identification with the inter-provincial Ottawa Valley that, as we have already seen, still over-rides the provincial border, in Shawville's collective imagination, if not in fact (Frigon 2007:xxviii).

The families who settled Clarendon Township and established the Village of Shawville were overwhelmingly Irish and Protestant. Armstrong's history of Shawville and Clarendon chronicles the arrival of the earliest "squatters" who established homesteads ahead of the official survey (1980:18-24), and provides genealogies for the families who received the first official land grants (1980:38-40). There are fifteen names recorded in the crown land agent's first Quarterly Return. Twelve are listed as having come from Ireland, one from Scotland, and two from the U.S.A (of those two Moore is an Irish name; McCagg is identified only as Presbyterian) (1980:41). ${ }^{82}$ One of the names on that list, Thomas Hodgins, provides a valuable

82 Enoch Padolsky's survey of the Ottawa Valley charts the ethnicity of Shawville's population when the village was incorporated in 1891: Irish 80\%; Scots 10\%; English 5\%, the remaining 5\% being French or German (1981:287). 
overlap between Armstrong's history and Elliott's work tracing the settlement patterns of Protestant Irish immigrants to Canada. Some of the details differ between Armstrong's and Elliott's accounts, but the core of the story reveals something of where many of Shawville's early settlers came from, and allows us a glimpse of their experiences arriving in the region.

Lloyd Armstrong records that,

Thomas Hodgins was born in the Village of Borrisokane, Tipperary County, Ireland... When Richard Talbot and his agents were inducing Irishmen to emigrate to Canada and settle the Talbot lands in Upper Canada, West, "Tipperary" Thomas and his wife and children joined the party and in 1818, with sixty families, made the voyage in the sailing ship Camperdown... When Montréal was reached there were many desertions from the Talbot party and among them were three of the Hodgins [there had been four related Hodgins families on board] who went up the Ottawa to Goulbourn and Huntley Townships... in 1821... Thomas went [on] to Clarendon with John Dale and decided to settle there permanently... It was about this time that Thomas began writing to his friends and relatives in Ireland and in some of his letters gave a very glowing account of this new land... these letters eventually brought a large number of other Hodgins settlers to Clarendon, making it the most numerous family in the Township. Thomas Hodgins became prominent among them and came to be known as "Daddy Tom". 83

(Armstrong 1980:20)

Elliott's telling of the story puts Thomas Hodgins, his wife Hetty (Pye) and their children aboard the Camperdown to make the crossing from Borrisokane to Goulbourn, but names them among a group of Tipperary émigrés who came across independently in 1819, a year after Talbot's crossing, in the Brunswick (1983:164-5). Elliott is also able to establish the provenance of other Clarendon settlers. "Clarendon", he writes,

was the earliest of the secondary settlements within the Ottawa Valley. Thomas Hodgins of Goulbourn and late of Borrisokane is said to have been one of the two men who first scouted out the area in 1821, but the major stimulus to settlement

83 The 2011 Phone Book has 63 listings for Hodgins (excluding 4 business listings) out of a total of 688 owned and rented dwellings. Hodgins relatives continue to be a significant presence in Shawville. 
there was the activity of James Prendergast, a former ensign of the $99^{\text {th }}$, who became settlement agent in order to secure a percentage of the land. Prendergast recruited heavily among former soldiers and other settlers in the Richmond Military Settlement, many of whom were already securely established on lands there, some of fair agricultural potential... The movement to Clarendon was thus not specific to any one of the groups of Irish immigrants that made up the older townships' population. The 1851 census of Clarendon reads like a roster of early Huntley families, Tipperary and non-Tipperary alike.

(Elliott 1983:294)

Elliott credits Talbot's expedition with setting in motion a pattern of chain migration that brought whole families and communities across from Ireland to re-form in clusters of friends and relations (1983:124). Talbot's settlers were "Protestant, loyal to the British crown, and possessed of at least the rudiments of literacy. Most were Yeoman farmers possessed of small means who could probably have afforded to emigrate without government assistance" (Elliott 1983:135). Although "the majority" of the passengers on the Brunswick had lived "within a few miles" of Talbot's home, Elliott highlights the social network that spread news of the expedition "across a wide area within North Tipperary" (1983:131). It seems that family connections and the writing of letters played a significant role in shaping the Irish experience of emigration. ${ }^{84}$ The first emigrants received their impetus from Talbot's organization and the promise of subsidized passage and free land. The hundreds who followed were pulled by good reports from family sent home in letters, and the reassuring prospect of family to welcome them at the end of their journey.

When it reached Canada Talbot's party divided, eventually establishing two settlements; one near London, Ontario, the other in the Ottawa Valley. Elliott is able to establish that secondary migrations, even the relatively small movements between settlements within the

84 I was given access to two letters exchanged between sisters in Ireland and Canada in 1830 and 1839 . They are significant as examples of the information and encouragement sent 'home' by those already settled in Canada, and also of the exrended family and whole neighbourhood migration patterns Elliott describes in his work. 
Valley, were governed by the same principles of chain migration and group clustering that influenced both where emigrants were drawn from, and their planned destinations. He explains that "the largest of these secondary settlements were formed by neighbourhood migration". Clarendon was settled by "clusters of Huntley and Fitzroy families" (Elliott 1983:302). This is significant because it means that even before they reached Clarendon the different experiences of de-commissioned soldiers, tradesmen, and farmers had begun to mix and percolate into a distinct 'Valley' character.

[Shawville is] a neat mixture of American settlers that got here right at the turn of the 19th century and Irish Protestants in the 1820s. Of course they couldn't hold a candle to the Scotch Presbyterians... The Scotch Presbyterians, I always liked them. I always tell the kids that it was the Scots ran this country and if you were an Irishman you worked for my guys: engineers and entrepreneurs... It's a really neat mix. Not as many English settlers; pretty small when you look at the census. Irish far and away.

(Gordon - historian/ high school teacher)

The name J.M.S. Careless (1969) is linked in Canadian identity studies to the idea that a Canadian national identity might be better understood as a collection of "limited identities", self-identifications that are not Canada-wide in scope, but limited instead by region, gender, class, ethnicity and the intersections of a wide variety of place- and time-specific identifications. Careless was, in fact, writing in response to Ramsey Cook, a noted Canadian historian who was the first to suggest that the "frame of reference" in the search for a singular Canadian identity might itself be the problem. Cook argued that, "[i]t might just be in these limited identities that "Canadianism" is found" (Cook 1967:663). Both Careless and Cook were quite comfortable with the thought of being "as Canadian as possible under [varied] circumstances". ${ }^{85}$

85 In 1971, as host of CBC Radio's This Country in the Morning Peter Gzowski ran a competition asking his listeners to finish the statement "As Canadian as... ?". Heather Scott sent in the winning entry - "As Canadian as possible under the circumstances". 
The idea that Canadians might construct for themselves versions of Canadian-ness ("limited identities") shaped by their point of departure, their destination, and their experiences along the way is echoed in the work of Political Economists. Gutman, for example, explains the divisions that make it hard to describe a cohesive Canadian working class by observing that "who workers bad been affected who they became" (Clement and Williams 1989:85 emphasis original). Each wave of immigrants was confronted with a new-to-them Canadian reality, but each of those realities was particular to a region and its staple- and geography-driven infra-structures and social organization. Each assimilation process was also mediated through the prior experiences and current resources of the new arrivals. According to this way of thinking the identities constructed by Canadians, particularly those collectively assumed by communities, are curbed and mediated by the particularities of shared experience, place and time.

I was struck by the similarities between Tipperary County, the launching point of Protestant Irish chain migration, and the Pontiac, specifically the socio-cultural and geographic isolation that defines both places. ${ }^{86}$ Elliott writes:

North Tipperary... constituted a social, economic, and cultural region distinct from surrounding areas... historically it had been quite distinct even from the southern part of the county. It's geographical situation in the Shannon Valley, ringed by wild stretches of mountain and bog, preserved its essential unity as a region despite its political dismemberment into several counties in recent centuries.

(Elliott 2004:13)

According to Elliott, the Protestant population of North Tipperary was, for the most part, descended from English families "who arrived in the region in the post-Cromwellian period" [i.e. after 1653]. The confiscations of land under Cromwell, the burden of a new land

86 You may remember my descriprion of Shawville's location in Chapter Three on page 66 - The town sits berween the relatively fertile lowlands of the river bed and the thin soil of the Canadian Shield, tucked between the river which constitutes the Ontario border and the Gatineau hills which separate the region from the rest of Québec. 
tenure framework, and the imposition of a new English gentry intended to encourage and bolster Protestantism left a bad taste in the mouths of Tipperary County's Roman Catholic majority (1988:21). Elliott describes the Tipperary Protestants as "a privileged but threatened minority being gradually overwhelmed by a burgeoning Catholic population" (1988:22), and experiencing a time of economic insecurity (1988:31). There were "very few jobs available outside the ailing agricultural and service sectors... almost no manufactures... no organized cottage industry, and the resources extraction industries which did exist... provided little economic opportunity for local residents" (1988:51). It is small wonder that the Pontiac, economically side-lined, socially distant and geographically isolated should have felt like "home" to the immigrants arriving from Tipperary.

Elliott highlights the importance of family and kinship networks in the movements of the Irish emigrants he studied. The practice of "chain migration" he describes privileged relationships and social networks over other considerations in the choice of whether and where to move (1988:8) ${ }^{87}$ Endogamous marriages reinforced cohesive family networks (1983:301) and intermarriage with neighbours in the new settlements established "the close association of kinship and place" (1983:302). As newcomers in a new land these communities constructed for themselves layers of belonging and familiarity by strengthening and creating ties to each other and to their place in space. Elliott explains that, "in clustering as they did the Tipperary people were similar to other groups of Irishmen who followed friends and relatives and were followed by their own friends and relatives". Echoing Cook and Careless he continues;

87 Interestingly, there is a lingering taste of the chain migration pattern in the decisions made by Pontiac High School graduates about whether and where to go to CEGEP. For a considerable time after the CEGEPs opened in the 1970s many Shawville students finished High School in Renfrew, preferring to move across to the Ontario system rather than participate in the Québec specific CEGEPs. Shawville kids now attend one of several English-Language CEGEPs, Heritage College in Aylmer (Gatineau), John Abbott College in Ste-Anne-de-Bellevue (Montréal), or Champlain College in Lennoxville (just outside Sherbrooke). As the High School's vice principal said, "Somebody heads down and goes to John Abbott. It's odd and it's talked about, and then it becomes "oh, well, so-and-so's daughter went there and I think that was okay". And suddenly it's not so scary. 
Though the patterns were similar in many regions the effects of Irish settlement were different in each because the people were not the same. An Ulsterman living among the Kawartha Lakes near Peterborough brought different attitudes, customs and inclinations to his new home and settled in a very different geographical, economic and social context from the Wexford yeomanry veteran of the 1798 uprising living in the back concessions of Loyalist Elizabethtown.

(Elliott 1983:6-7)

In the back woods of the Pontiac, Prendergast's de-commissioned soldiers, Hodgins' Tipperary kin, and homesteaders with varying lengths of experience drawn from Fitzroy and Huntley townships merged their backgrounds and resources to construct together a distinctive identity of their own, "limited" by where they found themselves, the experiences they brought with them, and by those they had along the way.

\section{"Fiddle and Twang" in the Valley}

Shawville contributes to and participates in the particular culture of the Ottawa Valley even as it affirms its own distinct character as a community. As one of the interview excerpts above insisted "if you weren't part of the village, you really weren't part of the village". Shawville, the people, distinguish between those who live in the Village proper and the surrounding rural township of Clarendon, with still sharper distinctions drawn between Shawville and the other village communities of Pontiac MRC. Nonetheless, as I argued in Chapter Three, Shawville shares in the Valley's cultural roots in terms of language, worldview, expectations, and ethnic origins. Within the Pontiac the distinctions between communities are familiar/ familial rivalries, necessary only to mark the particularity of each community.

Pat (dietician) highlighted two cultural performances buried in the everyday practices of food and conversation that mark the Valley's distinctive identity, and place Shawville clearly within the Valley's cultural milieu: 
When I say the preservation of old ways, because I have a deep interest in culinary things, food things, for me this is translated into an interest in the way the food... ah, culture? has been preserved. I notice that a lot. I don't know if I've been to all the various venues during the year but it's almost like a little ritual. Each month has its culinary, what shall I say?... outing... and I always noticed how well they were done. I think afternoon teas stand out in my mind, particularly the one at Stark's Corners, because they don't fuss around with Styrofoam and what not they go straight to the china, and the sandwiches are always ready and varied and so on and I think it just displays a kind of finesse that's gotten lost somewhere. I mean you pay 5 or 7 dollars for an all-you-can eat afternoon tea around here. I've been to the Queen Elizabeth Hotel in Montréal where you pay 25 for two or three eighths of sandwiches and maybe one or two petit-fours... and I've been to Edinburgh where its more or less the same thing at about the same cost, but here we are in the middle of nowhere and we know how to do things up in high style and that always pleased me... and the various other church suppers and so on that I make a particular effort to get to because they have their signature items you know, the pancake supper up at Schwartz where a little German thing comes out with potato pancakes and the apple sauce and the homemade sausages and the maple syrup from, you know, locally and so on... you can't put a price on these kind of things because they evolve from people's just kind of commitment to... I don't even think it's they realize it but it's a kind of commitment to their culture and the preservation of their old ways so that's one thing I've noticed about this place and I've always enjoyed it...

... The other thing I enjoy and I think it's leaving us sadly... I remember my grandparents and particularly my grandfather who was a dear, quiet, good man... his accent. You know that obviously must have come down the line from somewhere because this was a fairly isolated area and people stayed and they just have a certain way of speaking. ${ }^{88}$ Now there still are people who have a Valley accent and so on but this was something special. Mother doesn't have it because she lived too many years away, and I don't have it. You lose that in one generation and (snap) that's it. I liked that...

... I like the peculiar grammar there is around here; the conjugation of the verb 'to be'. I be, you be, he be... it's very simple. I like the way people pronounce things. When I first got here I was in my early twenties and there was a fine cook at the hospital by the name of Melba Wallace and she would say things like currots and I would say carrots, and she would say sangdwidges where I would say sandwiches... and there's my mother who says taiger where I say tiger, and another dear friend who would call them coocumbers where I would say cuecumbers... and I love words

88 One intriguing example of the impact of relatively isolated and stable communities on "specific ways of speaking" is exemplified in a study of the English learned and spoken by German immigrants to Renfrew County in the Upper Ottawa Valley. Thiele shows that since these German speakers learned English from their neighbours among whom "the dialect of the majority" was Irish there are "Irish features in the English of Upper Ottawa Valley Germans". 
and I love playing around with plays on words so these are some of the things that I noticed and I appreciate. And I remember when I first came I thought that I would have to speak the French that I had learned in Montréal. I certainly learned to adapt to not being too high brow and calling Fort Coulonge, Fort Cullunge and not needing to say it the so-called appropriate way. But anyway those are the... the things I notice run toward food, foraging and stuff with words, not too profound but there you have it.

In fact I found Pat's observations quite profound, an astute summary of how community is 'performed' in distinctive pronunciations and idioms, and constituted in the round of seasonal social events. These are precisely the everyday cultural practices that provide continuity, reinforce connections and re-state the existence and identity of a particular placel community like Shawville.

Studying the Ottawa Valley (in which she explicitly includes Shawville), Trew acknowledges being struck by the distinct character of the people and the place. She follows Joan Finnigan, a noted Valley story teller, in calling the Ottawa Valley "a state of mind, or an affair of the heart". Trew writes that people all across the valley shared with her stories that "conveyed a deep sense of connection to their past and to their place" (2009:3). Her entry into this place/state/relationship was through its songs, dances, fiddle music and stories. In them she recognized the "imagining of community" through performance. She reported the on-going re-statement of community as Handler has described it: a pro tem expression of community here and now mediated and expressed through a vocabulary of jig steps, fiddle tunes, and songs, again, the stuff of everyday culture. Through these "significant texts" Trew teases out the unwritten script, the constituting acts that give the community its being. In the Ottawa Valley, she says, these texts convey a "way of being" that encompasses "a sense of history; a sense of place; and the importance of community" (Trew 2009:4). 
Trew's most significant observation about Valley culture is its unabashedly "ethnic" character. In our interview, Gordon distinguished between Protestant Irish lumber gangs and their Scots, Catholic Irish and French Catholic rivals, suggesting that the lumber barons used the principle of divide and rule to manage the unruly men in their employ. Those distinctions have mellowed into rhetorical rivalries, but they still push back against the "de-ethnicizing" ${ }^{89}$ project of Canadian liberal nationalism, and the federal multi-cultural vision. Trew argues that the white, English-speaking 'ethnic' identities of places like the Ottawa Valley (and the Pontiac) ${ }^{90}$ have been deliberately over-written by Canada's official multicultural policy.

The erasure, or suppression, of English-speaking ethnicities was, Trew argues, a deliberate political act. She cites as an example the cancellation of a popular "Fiddle and Twang" television programme in 1969, just as multiculturalism was being introduced into the discourse of Canadian nationalism as an idea/ideal. "Don Messer's Jubilee", broadcast from the Maritimes, was a long-running favourite with a national audience. Trew argues that it, and the British Isles origin culture it represented and spoke to, became "disputed ground" caught in the cross fire of a contest over National identity as part of what she calls "Canada's post-colony makeover" (2009:252). The television programme's cancellation was protested all the way to the floor of Parliament. Trew is convinced that the TV programme lost favour with $\mathrm{CBC}$ decision makers at a time when Canada sought to distance itself from identification as a British colony and promote a new multicultural self-concept. There was no room in multicultural Canada for the "white Anglophone conservative rural working-class British Isles-origin culture" that Don

89 Arnopolous and Clift (1984:48) point to the long-standing myth that to be English-speaking is to be without an ethnic culture. English "culture" can then be positioned as "normative", a question of economic expediency and common-sense; not the product of a particular cultural-historical tradition.

90 Shawville's particularity is marked even here. The community's association with Methodism and the "Holiness Movement" would have complicated its relationship with secular music and dance, especially the Celtic tradition Trew calls "Fiddle and Twang" because of it relationship in turn with Roman Catholic communities. Participation in this aspect of Valley culture is more marked in other Pontiac communities (Sheenboro is an excellent example) which were settled by Catholic Irish somewhat later in the 1800 s. 
Messer and his guests represented and the people of the Ottawa Valley lived (Trew 2009:253). White (especially Anglo-Saxon) Anglophones were expected to become culture/colourless as the invisible backdrop behind visible minority "otherness"."

The agenda Trew describes puts Shawville in a strange position. Its claim to this place within Québec space rests on the community's history as Quebeckers and the inscription of this place as a particular place, home to the community's stories and memories. As part of an invisible "de-ethnicised" pan-Canadian identity Shawville would have no particular claim to this place, certainly nothing sufficient to serve as a counterweight to their exclusion from Francophone Québec.

In his assessment of the options open to English-speaking Québec under 'francization', Gary Caldwell describes two possible approaches. On the one hand, all of Québec's English-speaking citizens could pull together to form a united front backed by maximum numbers by drawing together a community of communities under the "Alliance Québec" banner. While that approach would have the obvious political benefit of numbers, it would risk what Caldwell calls 'de-culturation', it would mean subscribing to an identity spread so thin it will be no identity at all. On the other, Caldwell argues, English-speaking Quebeckers could distinguish themselves from both French-speaking Québec and English-speaking continental North American culture, thus affirming and mobilizing their distinct identity as Quebeckers (Caldwell 1980:218). If they do not claim their own distinctness, he warns, English-speaking communities within Québec remain alien to Québec. They will continue to be seen by French-speaking Québec as an enemy within the gates, a people rooted elsewhere with no investment in Québec's own particularity (1980:217-20). Shawville can, and does, draw on a long collective experience on the North shore of the Ottawa River to argue its place as a distinct community of Quebeckers.

91 See Mackey (2002) and Bannerji (1996) for further discussion of Canadian multiculturalism as a deliberate project of "othering" racialized minorities. 
The Anglo-Québec identity Caldwell dismisses as "too thin" is not part of Shawville's selfidentification. You will remember Gordon's words:

[Pontiackers] have always been individualists. The idea of clumping together [with other English Quebeckers] to tell our own story isn't - I don't think it's part of our makeup. We came, we were British North Americans, we were Canadians... That's probably more an indicator of the two solitudes than anything else - this idea that we're individuals. We don't worry about clumping together. We just are. We just do.

(Gordon-teacher/ historian)

English Québec was at a disadvantage in the work of building a language-based community in response to French Québec's cultural awakening. Speaking English was not, in the minds of those who spoke English, an important marker of identity. It was certainly not significant enough to bind together the scattered and distinct English-speaking communities of Québec (Rudin in Gagnon 1993:343). Whitaker (in Gagnon 1993:20) points to the long-standing entente within the English and French elites of Québec which had tidily put cultural concerns under the guidance of the French leadership, ${ }^{92}$ and economic concerns in the hands of the English. This division of spheres reflected the de-ethnicised status of English. English behaviours and beliefs, it was argued, were based on economic logic, the product of practical (i.e. economic) realism rather than ethnic identity or culturally based ideology (Arnopoulos and Clift 1980:43). Furthermore, the same liberal economic logic had "denaturalized" collective identities in favour of the autonomous individual, and devalued ethnic identifications as pre-modern and backward, or as constructed, instrumental and inauthentic (Angus 1997:17). Reed Scowen (1991) writes that "[t]o be understood in Québec politics, English-speaking Quebecers... must learn and use the vocabulary of collective action

92 England's readiness to leave Québec's schools and social networks virtually intact (as compared to its treatment of Ireland) reflects the huge change in the relationship between Protestantism and English identity in the time between the Irish conquest in 1530 and the conquest of New France in 1763. Stevenson writes that during those two hundred years the English had moved from guilty fear to tolerance in their relationship with the Roman Catholic Church (2006:60-61). 
and collective rights in a way that their cousins in the rest of North America would find unnecessary and even incomprehensible" (1991:91).

Rudin argues that while language was a sufficient identity marker to distinguish Englishspeakers from French-speakers in Québec, English as a shared language was not sufficient basis for a collective English-speaking Québec identity. Until they were faced with the need to defend their access to English medium schools and services, the disparate and distinct communities of English-speakers across Québec were just that; disparate and distinct (Rudin in Gagnon 1993:339-40, see also Caldwell in Bourhis 1984).

While self-ascription as English-speaking was not sufficient to serve as a link between communities across Québec, being English-speaking remains a significant identity marker within the community of Shawville. As I argued above, in response to growing secularization, Shawville's self-identification which had adhered in Protestantism fastened itself to being English-speaking. It is worth noting, for example, that one interviewee referred to learning to speak French as "turning French" (Elsie), while another argued that all the pressure to learn to speak French was pointless because "it's not as if we're going to convert" (Jared). The use of transformative or religious terms to talk about the acquisition of language is significant. So is the sense of threatened loss another interlocutor expressed in order to explain why Shawville parents were so reluctant to embrace the possibility of opening a bilingual education stream at the elementary school: we "didn't want to lose our English... that was a humungous issue". (Margaret)

Caldwell has challenged English-speaking Quebeckers to seize hold of their particular identities as a way to affirm their legitimate presence and participation in Québec. He points to the inevitability of their exclusion from a Francophone Québécois identity, and the 
danger of "de-culturation" as part of either a too-thin Anglo-Québec alliance or the toobroad English-speaking continental (non)culture (Caldwell 1980:216). Meanwhile, as Trew convincingly argues, Canada's federal powers have called on the same communities to cede (or downplay) their particular "en-cultured" identities in order to render "British Isles-origin culture" invisible. Shawville's particular 'ethnic' identity is reinforced within Québec because it has a visible and positive impact on the community's resilience. Ironically, the ethnic aspect of the community's particularity is positively reinforced specifically because it is inside Québec. If Shawville were elsewhere in Canada, its "British Isles-origin" character might be both less marked and less valuable as a distinguishing feature. Because of where it sits Shawville's self-description as an 'ethnic' Anglophone enclave has played a part in supporting the community's particularity and enhancing its resilience.

\section{Connections and Continuity}

The people I interviewed made up a "purposeful sample" chosen because they might be expected to be particularly "information rich" as members of their distinct 'circles' and as 'movers and shakers' within the community at large. ${ }^{93}$ Even so I was overwhelmed by their individual and collective grasp of local history and genealogy. Every one of them was able to share with me some part of their own ancestry and fit him- or herself into Shawville's tightly woven social fabric. The next few pages discuss the depth and density of the relationships that

constitute Shawville and contribute to the community's resilience. The discussion begins with my own observations and a collection of some of the varied cameos and anecdotes shared with me by my interviewees.

93 The concept of a 'purposeful sample' is discussed on page 44. 
Shawville's archives are presided over by a team of volunteers, women in their $70 \mathrm{~s}, 80 \mathrm{~s}$ and even 90 s, with a keen interest in preserving and telling their community's story. The collection, a wealth of documentary and pictorial evidence reaching back to the earliest military surveys, ${ }^{94}$ shares a new brick building on Main Street with the Public Library. In the archives I read local histories and scanned through back issues of the local weekly newspaper. I also listened to the conversations of the volunteer archivists, conversations that told of long friendships and deep roots in the community.

There is one incident in particular that stands out as an example of the sort of context-rich knowledge the archive volunteers shared. A man in his forties came into the archives one morning early in my time there. He introduced himself and asked for one of the archive volunteers. He told the room at large that he had already spoken to her on the telephone and that she (Elsie) understood what he was looking for. Elsie had just stepped out as it happened, so another archive volunteer (Pearl) offered to help until she returned. The man told her that he was looking for the name of a woman who had given birth in the Shawville hospital. He knew the location, the date, and that the woman had had two older sisters. He knew nothing else about her, except that she was his mother.

Needless to say, I had looked up from my own task and was listening intently by this time. The other volunteers were listening too. By the time Elsie returned several of the "archives ladies" were deep in conversation, trying the inquirer's birth date and the surname on his birth certificate against the births, and the young mothers, and the families with three daughters that they could remember. Elsie's return turned the conversation to musing about who might have been working on the maternity ward around that time (some forty years ago). At one point in the conversation, for just a moment, it seemed as though the man

94 The region was explored in 1792 by military officers in search of trees for masts and farm land to grow flax for sails. (Lloyd Armstrong 1980:14). 
would have his answer there and then. Someone had remembered a case that matched the specifics almost perfectly, but then some detail was disputed and they all shook their heads. They did not have the answer there among them. What so impressed me was that they were able to imagine that they might. Shawville's resilience rests on the solid footing of a long continuity of knowledge and experience. For the women volunteering in the archives that morning "being" Shawville included decades of shared memory.

The bi-weekly meetings of Shawville's town council offered further evidence of long association. At the first council meeting I attended I felt I had dropped into the middle of a long-standing conversation covering familiar ground. Issues were raised and debated while I listened unsuccessfully for any clue about the topic under discussion. By the third and fourth meetings I began to recognize some issues by the tags that were being used to identify them (often the first name of the person associated with the query or complaint, but the tag could also be as specific as "that accursed tree", or as vague as "the pipe" or "the pump" leaving me to work out whether they were talking about the water filtration system, the arena ice, or one of the town's vehicles). It was in fact not unlike being a first-time guest at a family dinner table where most of the conversation reworks known topics or begins in shared experience. There were even moments in every meeting when debate was side tracked while someone who came up in the conversation was "placed" - "he's Charlie's boy", or "she married the Hodgins lad" - exactly the sort of interruptions that classically pepper family dinner conversations.

When I asked about attending a Women's Institute meeting I was invited to be the evening's 'speaker'. My hostess was keen to hear what "the ladies" would have to say about my research project studying their community. My experience of that group then, was from the middle rather than the periphery of their circle. Towards the end of my presentation I asked the 
twenty or so women in the room to describe their community for me in a sentence, or a story. All of the descriptions spoke in one way or another about connection and family. When the room was quiet again someone asked the oldest woman present if she had anything to add. Her pithy reply was that she'd just let her relatives continue to speak for her. Amid much laughter my neighbour at the table leaned over and whispered, "after all, she's related to everyone here".

That meeting of the Shawville Women's Institute took place in a Retirement Home in Renfrew, on the Ontario side of the Ottawa River. My hostess informed me that the group makes the half-hour journey at least once a year in order to include several life-time members who now live in the Renfrew Home but remain connected to their lives in Shawville. I drove across to Renfrew with two women who spent the time talking about their grandson (her daughter's child in one case, her son's child in the other). My companions had known each other all their lives; their children had married each other. The layers of interconnection and relationship are everywhere to be seen.

My interview with William, the man I came to think of as a 'name gardener' (remembering Pearl's description of Shawville as a "nice seeding place") was not like the others. I took a different set of expectations and a modified set of questions when I went to meet him. William's name had come up time and again as someone I must talk to, a local history aficionado, a bona fide Shawville 'original'. His extraordinary gift lies in having watched over the community's "seedlings" for eight decades, taking mental note of their graftings and transplantings. William (Methodist minister) is a keeper of genealogies. I told him as our conversation began that I understood the engineering principle that in order to support a tall building you must make the foundation as many stories deep as you want to make the building high. I assumed a similar principle stabilizes trees, why not communities? I was sure 
that deep roots were part of Shawville's resilience and stability as a community. I explained that I was there to ask for his help to have a look at the community's foundation, its roots. "Oh yes", he responded, "I can help you with roots".

He was as good as his word. William showed me an extensive and complex genealogy producing and reproducing the various relationships that run through the community of Shawville. He interwove names and geography in a way that married people and places and memory. What follows is a very small sample of the knowledge stored in his memory. It will amply support my claim that the community's roots are both deep and well-knit in the earth.

Yes, you see Albert Armstrong's great grandmother was a McDowell of another family from ours. His great great grandmother would be a McDowell on our side and they lived down right there at the top of the hill. If one starts here at Clarendon Street and counts the five two-hundred- acre-lots... one - two - three - four - five; five lots. They were all connected to the McDowell's. The first one right here, that's in the town limits, that was John Armstrong married to a McDowell sister of my great grandfather's. So we're - we are related a great deal, yes. Inter-related...

... My ancestor buried up in the cemetery here, he would be my great great grandfather (I'm talking about William McDowell). He and his wife had 7 sons and 3 daughters. The [eldest] son came the year earlier (1822 we think) and had land down, the second lot down from Clarendon street. (And I remember his daughter there, Liza Caiter she was, she was a little old lady, and she was an odd soul she was.) The [rest of the] family didn't come that year because either the mother had a new baby or was expecting one right then and so they delayed coming for a year. But it meant that their whole family was born in Ireland. And she [the baby] was the old lady that was - she lived to be older than any of the connection. She lived to be 93 or 94 or something like that and she was known as, well all my aunts and uncles knew her as Hannah Knox...

... The Hodgins came from Nenagh in Tipperary. They had come a year before our - let's see, I think it was pioneer Thomas Hodgins who was nicknamed "Daddy" Tom [the 'Tipperary Thomas' of Lloyd Alexander's history]. Now that is written up in the big Hodgins book. And some of the Hodgins people went up to London area (north of London), but the ones that came here, they must have been writing back and forth to Ireland... There were several Hodgins families came, but the big Hodgins family came in, I think they were also 1835 [long after the 'pioneer' Hodgins in 1821]. That's William Hodgins and Mariah Stoney. They had either twelve or fourteen 
of a family. There were three daughters, one was married to a Cuthbertson (must have been from Bristol) one of them was married to Alec Elliott (and a lot of the Elliott connection is in there - there was a Hugh and an Alec Elliott)... I knew the grandchildren of Mariah Stoney. They used to tell me about her when they were young and she was at their home, Elliott's home, at her daughter's, and she was the old lady and so on. Oh yes, they remember Grandma Stoney... Mariah Stoney was apparently a marvellous woman. And if you take a person like Mickey Hodgins, see, Mickey's father and Mickey's mother were both Hodginses and they were all Stoney descendants. And you take the Portage Road, they were all Stoney - [Mickey's] father and mother were both Hodginses but second cousins and so on, but they're all the Stoney connection...

... The Mackechnie ancestor was a tailor in Glasgow (a tradesman rather than a tenant farmer), yes, and he and the Walkers from Antrim Ireland, they came to a place over in Ramsay Township - that would be there, south of Almonte, that's Ramsay township. And they got in on the rocky, hilly part of it where life was very difficult and so on, and they both left there and moved over into Bristol Township, onto the good land. And those two families intermarried. My mother's mother was one of the Walkers. My mother and Wyman Mackechnie were double cousins - the intermarriage of families there. The original Mackechnie was a tailor, so Wyman tells, but ever after they were farmers, and good farmers. The original Walker was I think (either he or his father) was a stonemason and had gone to (I think it was) Belfast in Ireland where he had learned how to turn an arch in masonry...

(William)

The "name gardener" guards in his memory the long shared past and tangled interrelationships within Shawville's community.

The first evidence of Shawville's tangled roots that I received was given to me in one of my earliest interviews. Albert told me about his recent trip "back" to Ireland. Even before the story began, I was struck by his description of the journey he and his wife made as "going back". After all, the speaker was three generations and a hundred and fifty years or more removed from Ireland.

My wife and I went back 4 years ago. We'd never been there before. My great grandfather came from there, but my grandfather and my dad had never gone back to Ireland... we got to go back and we went on a bus tour for eight days of the 
Republic of Ireland, the southern part. Then we rented a car for four days because we wanted to go out where we were from, because the tour wasn't in the northern part. So... anyway when we landed I said, "I got a funny feeling", and she said, "I got the same feeling - like you're home". We did the tour and went up to where we were from and saw the old grave sites. And her family and my family are in the same grave site. Her father was a Barber, her mother was an Elliott, and the Barbers, the Armstrongs and a few other people from around this area, their families are in the same area. The grave sites are falling apart, the tombstones are falling over, but we took pictures and departed with a good feeling. So I'm proud of who I am, and I don't want to be anybody different.

(Albert)

I told this story to later interviewees looking for their responses. No one was surprised. The only reaction I encountered in fact was to be corrected once. I had not given the Irish ancestor a sufficient number of 'greats', he must be two 'greats' at least since the great grandfather I had mistakenly named was known, by William, to be lying in the cemetery just up the hill here in Shawville.

Contributing to the sense of interconnection, within Shawville people and places are commonly identified in relation to each other. The Town councillors I observed identified potholes and burnt out street lights by their location beside "so-and-so's house", and stopped discussion about a job tender, complaint or petition to "place" the people involved. An interviewee admitted she couldn't give directions to someone's house by street name (some street signs and house numbers are only 15 years old) but she could tell you who they lived beside. "People here like to identify you by your relatives", I was told.

"David is fine, because he married somebody from here. Whereas [a woman] who taught with us was complaining she would never really be part of Shawville. Of course not! They like to be able to identify you, and if they don't know who your family is they don't know how to do that. 
The need for family as a way to be recognized led a later interviewee to protest that she had been driven to join a women's "unit" in the United Church as a way to create a proxy family before she could feel included. Another, describing how difficult it can be to make a space for yourself as a newcomer in such a tightknit community observed, "Maybe when you're part of such a large extended family you don't feel much need to venture out and meet new people". The many references to family are significant. They support my claim that kin networks and relationships are an important part of Shawville's self-identification. Whether portrayed as a positive or negative feature of life in Shawville, they remain inarguably a significant community trait. I contend that these defining and locating kinship relationships strengthen and support Shawville's resilience.

I don't know what it is that has sort of held this community as cohesively as - there were connections among the families and the neighbourhood around - well, in older times - when I think of my boyhood, for instance. See when this house was built; it was started in 1946 and was occupied in November of '47. I wasn't here at the time. I was away in University, but at that time see there was a fence right at the back of our land and that was field down there. The white house right beside us here, that's the old Shaw farmhouse, and this two hundred acre block, was Shaw's farm. The barn was down there where Mrs Rowat lives, and over there was the granary, and here at the corner of our garden was the gate going into the field. And there's a hollow spot right there at the corner of the garden, and that hollow was at one time the potato pit for Shaw's... I knew where everybody lived up and down the street and out through the country because I travelled the country with my father who was the physician and he would tell me the stories about people and who they were and all the rest.

(William-octogenarian/minister)

This has always been home. History gives you connections to family and neighbours. This is where home is.

(Jared-young father)

It's my own sense of history and desire to be close to family and friends. When I went away I was in the eastern townships, which is where my grandmother grew up so I wasn't really too far from home at all. I came back and did not know how I was going to make my way in the world but I knew where I felt I wanted to be. I knew I was never going to live in a city. I love the sense of community. I always 
tell the kids its sort of a double-edge sword. They worry about "everybody knows your business" and I tell them "yeah, but everybody knows your business". You do sacrifice your anonymity, but on the other hand there's such a support network that exists... You've got grandparents, aunts and uncles, friends and neighbours. I think about the people that live [here] and their families were our neighbours in Scotland... there's something here because both my brothers have come back and stayed.

(Gordon - teacherlyoung father)

Many of the people I interviewed, and others I spoke to more casually, repeated the now familiar trope of a community with deep ties over space and time. The interview excerpt below reflects Pat's unique perspective on the value and significance of these long-standing connections as someone who has lived both inside and outside the community, overseas and in various other parts of Canada.

I'm very interested in genealogy, and because my mother's from here I've done quite a lot of hunting about and looking at where people come from, looking at surnames that are still here since 1820. I think that this town was built on a whole bunch of people coming from exactly the same place, and I don't just mean "oh, we came from Ireland". I'm not talking about that. These people, almost all of them, came from a little pocket of three or four counties in the North of Ireland or what's the northern part of regular Ireland now, Antrim, Downe, Armagh, and Fermanagh. These people knew each other before they left. They were all related, and then they all plunk themselves down in the New World, as they like to call it over there, and they just keep it up, continue. I think that must have had a huge cohesive effect on this place. And many of those people, those family names from Northern Ireland, they're not Irish, they're Scottish, and it's almost like they're a story of successive migration in groups, in family groups. I'm sure. So you have all these people, these same families, leaving Scotland, I'm not exactly sure when, ending up in Northern Ireland, and at some point ending up in Canada, the same bunch of people sticking together. I think that's got to have something to do with it [resilience]. And I think if you think about, you know, I always thought I was Irish and there's definitely a bit of that but I realize we're largely Scotrish and I've just been to Scotland once and it was like "ooh, I get these people". And I know it's been said a million times and it's kind of sappy but there's a kind of a fight in them, and you used the word resilience and its very much... I don't think Shawville is an accident, I think it's genes. I think it's genes that stopped off here and there in various countries but the genes don't change. There's a kind of tenacity and a kind of stubbornness. So maybe what we're dealing with in Shawville is we're tasting a tribe, we're tasting the concentrated genes of a certain sort of personality... Coming home to Shawville is like 
finding my lost tribe. We don't have any more this concentrated representation of who we are - and we need it.

While acknowledging the obvious objections that could and should be raised to conflating personality and genetic heritage (not to mention the problematic word 'tribe') the observations remain significant and revealing. ${ }^{95}$ Pat is celebrating her own sense of homecoming and contentment in finding herself reflected in those "concentrated genes". She is pointing to both the existence of Shawville's deep roots and the comfort of settling into them, acknowledging the affirmation inherent in seeing ourselves reflected in those around us. It is good (and restful) to feel recognized and recognizable. Pat experiences the feeling of recognizing herself in others and being recognized by them in turn as an antidote to anonymity and anomie.

It is a measure of how significant these communities are that where they do not exist for us, we create them for ourselves. A story I was told recently (not in Shawville) will serve as a good example. The speaker told me with evident relief about the wonderful school her granddaughter would be attending in her new home in Dubai. "No one has family there" she reported [obviously referring only to the ex-pat community among which her daughter's family number], "so they're family for each other. They have birthday parties and a big Christmas dinner at the school. They have to be family for each other". Anyone who has spent time as an 'ex-pat' overseas is familiar with the scenario, strangers thrown together by circumstance who recognize the familiar in each other against the backdrop of a foreign world. There is respite in spending time with others who 'reflect' back to us the reality (validity) of our own experience and are familiar with the assumptions between our spoken words.

95 Here as elsewhere I follow my pre-disposirion to use ideas as launching pads, gaining height or traction from what strikes me as interesting rather than becoming mired in critique. If knowledge is contingent ideas can be assumed to hold both useful and unproductive features. I prefer to invest in what I find useful. 
As part of the discussion of employment options in the last chapter, many of my interviewees expressed the value of work that allowed them to remain within the community. The ability to "stay home" (i.e. to live within the local context) was clearly valued more highly by many of those I spoke to than the prospect of more options and opportunities if that meant going elsewhere. Albert, who worked in a mine up north for a time before returning 'home' to take a job with Hydro Québec, described his time away as an adventure. He justified it as a short term thing. It would be okay because several other guys from home were already there, and because he would be working with an uncle. Albert clearly felt real life (i.e. marriage and family) was to be lived "at home".

Debra affirmed the value of "home" describing a recent encounter with an old student:

He's in his 20s and I was talking to him and asking him how he was doing, and he said, "I did a few years working down in the city 'till, you know, I came to my senses and came back home to live the good life". His words. And he said, "You know right now I'm driving back and forth but I don't want to be down there. I want to be up here where I know people".

(Debra)

In this anecdote the young man who describes himself as "coming to his senses" defines "the good life" as a life lived "back home". Jack, who worked a life-time at the mill before running for public office, affirmed the value of "home" defending the job a one-time mill employee had moved on to after the mill's closure: “It's not a big paying job but it's a job where you can still stay home". Jared and Holly expressed the importance they give to continuity and their pride in the long connection to place and family. Their two children are the sixth generation to live on the family farm. The continuity clearly delights them:

And there's funny stories, like just down the road [my husband's] grandpa went to school... and he was a Hamilton, and my Grandma Rita... she was a Mulligan, and he used to sit behind her in school and pull her pigtails and she'd give him hang for 
it... and Grandma, she and Grandpa lived just a three minute drive from here. And now we are a couple living here.

This has always been home", Holly and Jared declared warmly. "History gives you connections to family and neighbours... This is where home is."

My interview with Margaret touched on a potential conflict between the need to go away for post-secondary schooling and the hope of many students and their parents that young people will remain in or return to the community. Margaret's specific concern was that local children must leave home in order to go to University or CEGEP (or "travel" back and forth to Gatineau every day, a trip complicated by the near absence of public transport).$^{96}$ She was troubled by the thought that having once left home young people might be less inclined to come back. Our conversation explored the potential social costs of this enforced distancing. Margaret expressed surprised gratitude that both of her own adult children did return to live and work in Shawville.

Allan, he never (it was a two and a half year [CEGEP] programme at that point), he never stayed down one weekend. The only time Jennifer stayed down was after Allan graduated. Then she was there for the last, I guess it might be four months, without him so she didn't make it home every weekend. It was just because she had no transportation home. It's very typical of people from this area. Of course now when you see young people (and anyone who's younger than me is a young person), young people who have worked away in Mississauga or... When they have an opportunity to come back to Ottawa, or as close to Shawville as possible, well they're up for that commute... It just thrills me when I see people like Holly $\mathrm{R}^{* *}$ purchasing a house and settling back here. But I always thought this was a little unusual.

(Margaret)

96 There is a single commuter bus down highway \#148 daily. Its schedule is geared to the needs of civil servants working 7:30 to $3: 30$ in Ottawa. It is not easy to coordinate with a college or university class schedule. 
I have not formally compared Shawville to other communities to know whether this tendency of students, labourers and the retired to return "home" when they can is in fact anomalous or "unusual". In my experience something similar is true of at least some other small communities, but the strength and scope of Shawville's magnetic pull is noteworthy. Its effect on those away studying or working came through in many of the interviews I was granted (and was reinforced by the content of The Equity's gossip columns and social news pages). The idea of Shawville as a "centre" in its own right (socially, as the service centre for the region, and symbolically as the heart of a diaspora) has significant implications for the community's capacity for resilience. Its sense of itself as complete in itself allows the community to feel comfortable with its independent status. Being auto-referential (another expression of its particularity) enhances the strength of the community's "zone of attraction" and increases its capacity for resilience.

The ability to "stay home" or get "back home" was important to my interviewees. Its value is reflected in the way it guides choices about where and how to work, and how "the good life" is defined. In Shawville's collective narrative "home" is a "good". It is a name for the “determinate ontological relationships" (Hardt and Negri 2000:202) through which our 'being' is constituted and defined. To "be home" is to "be with" those who best reflect back to us the particularity of who and where we are. Home, understood here as our 'particular' place/people/context, is the compass point that allows us to keep our bearings.

The commitment to a particular people/place encompassed in the value "home" contributes to the strong centripetal force in Shawville's resilience basin. In the case of this community the attractive lure of "home" inspires many to find a way to stay and live and work here. It is sufficient to bring college students home for weekends, distant families home to multigenerational summer cottages, and pensioners home for their retirement. ${ }^{77}$

97 Data collected in Shawville interviews spring and summer 2010 
According to Brubaker and Cooper, the term identity denotes "a location in social space" that locates us in turn. It implies a "fundamental and consequential" sameness within a group, and an "abiding" sense of self (Brubaker and Cooper 2000:7). We have seen that Shawville's sense of self is firmly grounded, consequential and abiding. The community's resilience, its ability to integrate change without changing its own state of 'being', is enhanced by the deep roots and tight interconnections that provide it with a profound source of meaning and a versatile capacity for meaning-making in the form of shared memory, association, and social vocabulary.

\section{Being Shawville}

Words like 'identity' and 'community' (and all the other 'reifying' terms Handler councils us to distrust) prove most productive when they are interrogated as questions rather than accepted as answers. "What are identities for"? "What do communities 'do"'? These abstract nouns can be re-cast as 'verbs'. Handler, introduced early in this chapter, described nouns like identity and community as "symbolic processes". The words themselves construct and shape the ideas so that every time we think or talk about them, each time we enact them, they are reconstructed and given fresh 'being'. In Handler's own words, "every statement about "who we are" changes if only slightly, our relationship to who we are" (1994:30). In his work, The Politics of Identity in Québec (1988), Handler challenges the conception of an identity as something "bounded, continuous and homogeneous". He is particularly concerned to challenge the notion that a changeless, authentic identity exists (that it has or had a 'true' moment) ignoring the fact that an identity is always 'becoming' (1988:15). Handler works to de-nature our sense of identities as given and immutable. He cites Goffman's quip that although we tend to treat it as such, the existence of one identity per person is not "a law of physics" (in Handler 1994:31). Handler's concern is to point out that identities are cultural 
products (1988:10,89). The social expectations and conventions through which identity is articulated, he argues, are not static 'natural' facts but a negotiable vocabulary "arbitrary, contingent and subject to reinterpretation" (Handler and Segal 1990:15). The act of "identification", individual or collective, becomes an event: recursive, fluid, contingent, and momentary.

Brubaker and Cooper push this argument further to insist that we acknowledge the existence of a subject behind the act of identification, the someone who is 'doing' the identifying and/or 'being' the community (2000:15). They insist that the act of identification (selfrepresentation) is a "conscious, articulated projection" (Brubaker and Cooper 2000:18). From this perspective, all identities (and all communities) are deliberate constructs "perpetually undergoing reconstruction" (Balibar and Wallerstein 1996:228). Every "event" of being Shawville is both like and unlike the previous performance, re-balanced to better navigate the particular circumstances of the moment. Deliberate, "strategic and positional" (Hall 1996:3), identities "suture" the subject into a particular moment/reality (Hall 1992:277). They establish a piece of solid ground under our individual or collective feet, and are used to establish that ground where it will serve the identifier to advantage, whether we are identifying ourselves, or ascribing an identity to another.

All of these ideas are at play in resilience theory's model of adaptive cycles, most specifically the insistence that there is a sort of change even within stasis. Each 'event' of collective identification responds to the particular topography of the here and now in reconstituting itself, each performance is both like and unlike the last.

The idea of agency (both internal and external, our own and others') within the adaptive cycle of disruption, rebuilding, growth and consolidation comes through especially clearly 
in Trépanier's refondation model. I described Trépanier's analytic tool in chapter three of this work where it served to illustrate the deliberate and negotiated identification of a place in terms that would make that place most meaningful to its community. In that context we discussed the way that Shawville renegotiated its location in space to its own advantage by privileging inclusion in the Ottawa Valley over exclusion from Québec as the defining characteristic of its ambiguous location. In this chapter Trépanier's model again serves to articulate the relationship between meaning-making and a community's capacity for resilience, this time through the lens of identity construction.

As we saw in the earlier discussion, Trépanier's refondation model, like Holling's adaptive cycle, describes the dynamic process of disruption and renewal that drives adaptation. In Trépanier's model, 're-grounding' (refondation) events are shaped by the interplay of tensions she calls 'poles'. In Holling's model identity events reflect and react to a cycle of adaptive stages. Both models express the same collective work of accommodating new realities while maintaining a recognizable sense of self. In terms of my analysis Trépanier's model is a helpful supplement to resilience theory because it highlights the singular place of meaning in the well-being of human communities, and its role in their "volonté d'équilibrage" (the will to keep their balance) (2005:9).

Resilience theorists who have applied the model of adaptive cycles to human organizational and socio-political systems describe including people in their studies as challenging. Gunderson and Holling, for example, explain that "linked ecological, social and economic systems" were unlike the other organisms and ecosystems in their experience $(2002: 20)$. They report that what sets human systems apart from systems without humans is that people have an absolute need for 'meaning'. To understand resilience in social systems, they argue, it is essential to acknowledge the key role of "sense making". Their observations convinced them 
that, "If meaning is lost, human systems seem unable to recover" (2002:108). Meaning, then, has unique and defining significance in maintaining human communities. It holds the ground steady under our feet and is vital to our resilience.

The four poles in Trépanier's model stand for four dichotomies or tensions that both drive and limit the work of collective meaning-making and self-identification. The 'poles' are labelled: péril (threat), excentration (marginalization), appartenance (belonging) and renovation (renewal). Refondation, the re-grounding of collective identity, "est issue d'une dialectique complexe entre quatre elements: péril, excentration, appartenance et renovation de l'heritage " ["is the product of a complex dialectic between the four elements: danger, marginalization, belonging and renewal" (Trépanier 2005:80 translation mine)]. Superimposing Trépanier's poles onto resilience-theory's "equilibrium basin", as we did in chapter three, illustrates the relationship between our need for meaning and our ability to recover our equilibrium. The limit of a community's capacity for 'sense making' constitutes the brink of its equilibrium basin, the space available between the tensions the poles represent equals the square footage of solid ground available to the community, the extent of its capacity for resilience. The closer together the poles are, the narrower the equilibrium 'basin' becomes. In terms of the resilience of identities, lack of room to move equals vulnerability. An identity that is too brittle (where the tension between the pole elements is too high) is no longer resilient.

Trépanier describes the tool she constructed as a working assumption, an analytic tool rather than a hypothesis to prove or disprove (2005:39). Treating her model as 'something to think with' I have taken liberties in translating and adapting her work in order to address specifically the context within which and out of which the community of Shawville must make sense (i.e. meaning and intelligibility). In Shawville's particular context, the abstract 'poles' of Trépanier's model take on specific concrete forms. The tension between survival and 
assimilation (péril), for example, was most often expressed by my interlocutors in relation to a perceived threat of assimilation by Francophone Québec, or eventual extinction as Englishspeaking Quebeckers. Other potential sites of threat or danger (the lack of local employment opportunities, the beleaguered state of farming, Shawville's aging population) never carried as much weight in the narratives of my interviewees as the possibility of assimilation by or ejection from Québec. That was the form of peril that 'counted', the peril that carried the weight of meaning. As might be anticipated within such a context, every iteration of Shawville's identity addressed this perceived threat, affirming the community's "Englishness", its distinctness from Québec and its long history within Québec.

I interpret the pole excentration as the tension between exclusion from some external centre and exceptionality grounded in an internal core. Shawville, whose expressions of self-identity are sometimes auto-referential, sometimes rooted in the Ottawa Valley, invests its identity in its own sense of distinctness, and its on-going relationships with communities across the Ottawa river. The 'centering' that carries meaning for Shawville lies outside Francophone Québec. The community's self-ascribed identity as a centre in itself and as 'core' within the valley resolves the tension between exclusion and exceptionality by claiming to be exceptional/distinct.

Much of this chapter addresses Shawville's position relative to the third pole, appartenance, which I have interpreted as the tension between belonging and not-belonging, between coherence and discontinuity. The community's long and intertwined history gives its identity both coherence and continuity. So far Shawville has managed to remain intelligible and recognizable to itself. While many other English-speaking communities in Québec find their stories increasingly irrelevant, incoherent in the present and/or discontinuous with the past (Marshall 1995:13), Shawville, as I have shown, continues to experience and to demonstrate 
the vitality and relevance of its collective history and sense of connection.

Much of the coherence Shawville has preserved has to do with its attachment to place, the "living museum" of its "home" space (Robert). This coherence and continuity speaks to a question I posed early in my study. "Why didn't the English-speaking community in Shawville pull up stakes during the exodus of English-speaking Quebeckers from Québec during the 1960s and 1970s? Clearly, the rise of separatism in Québec and the possibility of separation from Canada were experienced as threats by the interviewees who described opening bank accounts in Renfrew prior to the 1980 and 1995 referenda, and those who made a case for their own secession from Québec if Québec's separation from Canada were to become a reality. I am convinced that the most credible answer lies in changed circumstances at other scales affecting the push and pull of Trépanier's posited poles. The earlier migration from Ireland to Canada (and earlier still from Scotland to Ireland) were pushed by restricted economic possibilities at 'home' and a growing sense of threat as a minority population (both 'push' factors at work in the current situation as well). This time though, moving also presents a threat. There are no land grants or government settlement programmes to make settling en bloc possible. Moving on would mean moving apart, there is no chance of "neighbourhood migration" as Elliott described it. For the time being the threat posed by limited economic opportunities is being managed by temporary absences from 'home' (in some cases a working lifetime of absence), with the promise of summer visits and eventual return with retirement. The threat posed by the community's minority status in Québec is mitigated by its standing in the Ottawa Valley. The community has yet to experience a sharp division (a discontinuity) between its past and its present. Moving on would be the end of Shawville as Shawville. 
I have now considered three of Trépanier's poles (peril, marginalization and belonging) as they relate to meaning and meaning-making in Shawville's self-identification. The final 'pole' in the 'refondation' model expresses the tension 'conservation/renewal' (la rénovation d'heritage). It addresses the work of 'renewing history', of re-framing our stories to best explain the present and support the future. Just as a family's home might be renovated both to keep it in good repair and to accommodate changing household configurations and needs, the 'rénovation' of a community's story, the representation and projection of its self-understanding, addresses a changed and changing present. Renovating history means writing over pieces of the story that no longer serve to explain the present, or to open a way into the furure. When Jocelyn Létourneau, for example, challenges his peers to rethink history "[r]emembering (from) where they are going" (2004:19) he is asking them to shape their narrative in relation both to the now known future of past events, and the as yet unknown future desired by the present. His goal is to find a solid footing for the future in the community's on-going narrative, to remember the past in ways that give priority to the future. Not to do so, argues Létourneau, is to allow the future to be "mortgaged by the past" (2004:15). As Daniel Francis expresses it, when history as we have been telling it "no longer explain[s] anything" it needs editing and renewal (1997:174). Francis argues his point eloquently, "The stories we tell about the past produce the images we use to describe ourselves as a community. If we are not telling ourselves the right stories [i.e. stories that adequately reflect who we are, and explain to us where we are], then we cannot imagine ourselves acting together to resolve our problems" (1997:176).

Shawville's stories about itself are part of an on-going conversation that subtly and constantly adjusts how and where it is "sutured" to the present moment. They contribute to a process of adaptation and rénovation that modifies the emphasis in the community's declared identity to respond to shifting tensions within its context. For now, and for as long as Québec's own 
identity construction continues to pose a perceived threat to the community, Shawville's story will affirm its deep roots, long continuity, dense interconnections and location within Valley culture. Distinctness, rootedness, and "Englishness" are salient features of Shawville's particularity in the current moment and thus of the community's present capacity for resilience. It is beyond the scope of the present work to do more than point toward the trends shaping possible future contexts and their impact on which features become salient.

From the beginning of this work I have pointed to the production and reproduction of Shawville (place and people) as a kind of performance. The idea elegantly incorporates both the collective and the dynamic nature of community. To be a community requires a collective effort, a shared idea of how things 'tick', and enough flexibility about the 'rules of the game' to allow for and even facilitate adaptation and renewal. In this final section of chapter five I return to the idea of 'being' Shawville as the repetition and performance of constituting acts. I provide some theoretical background for the idea of "performativity", some examples of performance overtly incorporated into community life, and some examples of performance unconsciously reproducing community. This section ends with a summary of community resilience articulated by one of my many knowledgeable interviewees.

Judith Butler, like Handler above, describes identities as social products. Our individual identities, she claims, are "tenuously constituted in time" through the "stylized repetition of acts" (1988:519 emphasis original). She describes the work of self-identification as "a sustained and repeated corporeal project" performed "in obedience to an historically delimited possibility" (1988:522). Butler's notion of performativity allows us to conceptualize the interactions and behaviours of a collective in similar terms. A community's character and identity might also be thought of as the "legacy of sedimented acts" (Butler 1988:523). The possible actions and reactions of a collective might be similarly constrained by precedence, 
tradition, and the need to live up to a particular self-concept and/or the projections and expectations of others. If, as Butler suggests, we constitute ourselves and our "social reality through language, gesture and all manner of symbolic social sign" (1988:519), it is not much of a leap to imagine that the constitution of communities and shared conceptions of the world might be constructed in a similar fashion using similar symbolic tools. According to this view, communities too are constituted in performance.

The idea that identity is constituted in acts is also reflected in Bourdieu's notion of habitus, the quintessence of stylized repetition (1990). Bourdieu uses the term habitus to describe the "structured and structuring dispositions" through which people organize and understand the world, the assumptions, attitudes and practices that define and limit what people (collectively or individually) find expectable and acceptable. Our babitus 'clothes' us in the patterned behaviours (habits) and already-made (habitual) decisions that give us a "feel for the game" and allow us to navigate anticipated decisions and interactions with unconscious ease $(1990: 61)$.

The act of 'being' Shawville, as a performance, or according to the overt and implicit rules of a game, was nicely illustrated in one of my interviews. Although my interviewee, John, had practiced medicine in this community for 27 years, he reported, as many other "newcomers" did, that Shawville was a difficult community to become part of. As he explained, "It doesn't put barriers up to people joining the community, but it's not particularly made easy either so it takes a long time to actually learn how the community ticks". The rules to the game are habitual and thus ill-defined and unspoken.

Among the things that are attractive about Shawville is that it's... The town is very proud of its existence. It's not particularly apologetic about the things that make it different from other communities which ah... make it in some ways that you have to know all the codes to really fit in, but that it has some sort of internal consistency 
to it which is durable over time. And I even see it in the kids, you know, who were toddlers and quite a number of whom have stayed around, in contrast to the typical thing where all the kids leave, and they are, you know, very much in the mould of their parents. Many of them that I see... the kids who become Miss Shawville Fair and who accept that its part of what living in Shawville is about. It gets modulated with time but it doesn't... it's still very much the same, I think, as it was when their grandmother was Miss Shawville Fair... and I find that over time (it's very easy in the early years to kind of dismiss that if it's not part of your own personal experience) I find I have more respect for it as time goes on... partly because of its durability. I think it's to the credit of any community to have a sense of its self and it's always sad when a community loses that.

I asked John if he had been able to discern what did make the community tick. It proved to be quite difficult to pur into words. Predictably, "unwritten codes", "internal consistencies", "repetitive constituting acts", and the "feel" for a game whose rules are constantly and unconsciously renegotiated are hard to pin down. Near the end of the interview he returned to the Shawville Fair as a significant piece of local drama and we both realized that what he was describing was exactly what he had struggled to articulate. He was describing an elaborate performance of 'being' Shawville.

It still has quite a lot of its content [the Fair], even the quilting, you know, the demonstration of skills that exist in the community behind the scenes that are kind of a reminder that there is an infrastructure there that's the same year after year. And you get to show off the agricultural base of the community so the Fair is sort of not changed... It still does well and attracts a lot of people and showcases... in a community that was losing its sense of itself I would imagine it might try a whole bunch of different things, would try different things every year. One thing I can remember is their little flirtation with the casino about 15 years ago... They brought in an actual casino module, it was in one of the buildings, with these guys in tuxedoes at the door, these, you know, bouncers, with very much a sort of Las Vegas look to it and there was real money on the line and it was such a clash with... the $\$ 3.00$ vegetable prizes... the values, with the $4 \mathrm{H}$ booth next to it, that it wasn't a moral deal, it was just so discordant that they never did it again. It made tons of money as casinos always do, and they were a bit cash strapped and so it seemed like a good idea, and lots of people from Shawville go down to the casino [in Gatineau] and gamble but they're doing that outside the community and so it doesn't matter. But when they imported that into the heart land it was a really interesting lapse in 
judgement, lapse in understanding. I don't know how the decision was made or who was on the Fair Board then, but heads rolled as a result of it. It was more interesting for having come and gone as an example of what fits and what doesn't than anything that I've seen at the Fair since.

(John)

Although it may be difficult to identify ahead of time what 'is' and what 'is not' part of being Shawville, John's example demonstrates that there is little doubt after the fact that this or that action could or could not be grafted neatly into the performance. How far the community might be able to stretch the defining perimeter of its resilience basin depends on its ability to make sense of the new limits within its sense of itself. A casino "imported into the heartland" did not "fit".

The way medicine is practiced in the Shawville hospital provides another window into the performance of Shawville. John had only just begun to describe how things are done within Shawville's medical community when it became obvious that what he was describing was Shawville itself. He emphasized continuity in relationships (a person cared for by the same doctor across a lifetime), continuity in place (grandmothers, mothers, and daughters sharing the experience of giving birth in the same physical space), and continuity over time (a doctor attending the delivery of a baby whose mother's birth he also attended).

I often tell this story at conferences and... about delivering a baby while the grandfather was dying in ICU, and having both events happen within minutes of each other, and the whole family in the one place dealing with those two opposite events across three generations... a sort of microcosm of what the community's about, because half of the care providers were connected in some way to that family and would know them and would understand their emotional place and be able to support it to the extent that they were there and knew what was going on. You don't... there are too many barriers to allow that to happen in most places that are much bigger than this. It won't happen because it can't happen. The events don't happen in close enough proximity to each other with people who can make the bridges between them. 
There's a similarity in the evolution of the community and the evolution of its services which maybe one shouldn't be surprised [by], that communities are places where certain kinds of services can develop and other kinds of services can't, and they will [both] be changed by changes [to either] coming in from the outside.

(John)

What John is pointing to in the second excerpt above is significant. The way health services are provided within Shawville is consistent with the community's "performance" of itself. How things are done in Shawville becomes an expression of self-identity, and that identity plays out in how things get done.

The interview excerpt below makes such a clear and passionate statement about the importance of Shawville specifically, and places like Shawville more generally that I will give it the final word in this discussion. John eloquently sums up the connection between a community's identity, its particularity and its capacity for resilience.

What strikes me about communities is that very different communities have similar passionate loyalties from the people that live there. There are Hollywood movies about it - a town in New Hampshire or something, and the New York lady goes up to close the factory and ends up being seduced by the town or something, and the community buys the factory. They're fairy tales about community resilience really - so the elements can be present in many types of communities. The basic theme is that people really need... not only do they create that sense of connectedness, but they really need it. You want to be a part of something that you can say is who you are and I think just because Shawville is different enough from the surroundings that people can say, "that's what's different about us", makes us important, and we hang onto that. Maybe it comes out of a need as much as out of a real thing. Maybe you can manufacture it out of just about anything that you have unless some sort of catastrophe comes and just sort of sweeps it out of the way. Maybe it isn't so much a thing as people define themselves by what's there, and then they become what's there, and that becomes their passion, and maybe that's what sort of keeps the ball rolling... a strong need to keep it together. Having done it makes you believe that you can continue to do it, which is a good thing... Maybe wishing makes it so". 


\section{Conclusions}

Shawville's narratives about itself are replete with history, place and belonging. The people I interviewed and recorded, and the many I spoke to less formally, described their community as distinct, tight, proud, independent, persistent, tenacious, and comfortable. It is a place with deep roots and long connections, a place of "concentrated genes". Deep and interwoven connections attach people to each other and a community to a place in the same way that the foundation under a building gives it coherence and structural integrity. In Shawville's case the foundation is deep. It reaches back through multiple generations of interconnection, shared history and a wealth of shared experience. The community's identity exhibits internal coherence in the clear demarcation of its boundaries, and confirms its cohesive quality in the vitality of its centripetal core. Shawville's identity adds a further dimension to its capacity for resilience in the form of deep and interwoven roots. Shawville's marked sense of its own importance contributes to its particularity and enhances the community's resilience.

Chapter Six recaps the factors this work has identified as contributing to Shawville's resilience: a rich and deliberate sense of place, relative isolation and economic doldrums, as well as ontologically determinate connections. It describes these factors and their implications in terms of the insights of resilience theory, with specific attention to reintegrating social and 'natural' systems in our conceptual framework, and addressing the inherent contradiction between resilience (sustainability) and growth. The discussion then moves to address the specific imperative of meaning-making and the human need for particular place/ communities before returning to the relationship between particularity and community resilience. The final section addresses Troughton's call for a model of operational structures and policy that would acknowledge the importance and support the resilience of rural places and their invaluable particularity. 


\section{Chapter Six: Conclusions and Questions}

\section{Introduction}

In Chapters Three, Four and Five, I presented and interpreted resilience theory through Shawville's particular geography, political economy and socio-linguistic identity. I used examples drawn from my study of Shawville to explain and illustrate Holling's "adaptive cycle" and "resilience basin"98 models. In this final chapter I turn the analytic tool I have used on end, reversing this perspective. Instead of explaining resilience theory through Shawville, the pages that follow interpret my claims about Shawville through the insights of resilience theory. By using Holling's (1973) "resilience basin" and "adaptive cycle" models to account for Shawville's current strength and the factors that support it I insist on conceptualizing Shawville's community as a social system, different from but not 'other' to the ecological systems the models were designed to explain.

This work began with the question, "Shawville?" My research asked, what sustains this community? How might we account for its persistence? What assets and attributes support Shawville's resilience? The preceding chapters of this work showed that Shawville's perseverance qua Shawville rests in the community's particularity, its rich and deliberate sense of place, its real and imagined isolation and economic doldrums, and its tightly interwoven social network. Exploring the implications of reliance on those factors to Shawville's resilience specifically suggests potential ways to support rural community resilience more generally. Shawville's exaggerated circumstances (inside and outside Québec, outside and inside Ontario) have made its resilience conspicuous and thus easier to see and examine, but much

98 Refer to illustrations of these models on pages 15 and 17. 
of what is true of Shawville is, no doubt, true in one form or another of other particular place/communities across rural Canada.

My research found evidence of Shawville's capacity to navigate adaptive cycles while maintaining a resilience basin (or "zone of attraction") wide enough to allow for flexible footing, distinctive enough to exert its own centripetal force, and robust enough to weather the slings and arrows of stochastic and unpredictable events at other scales. The work of this chapter is to clarify the links between these characteristics and capacities of the Shawville community and the insights of resilience theory. I have deliberately used models drawn from the study of ecological systems in order to think about a social system as a form of ecological system, locating human beings within the constraints and interactions of the natural world.

The discussion in this chapter begins with an expanded restatement of resilience theory that will serve both to resituate this work in interdisciplinary space that weds ecology and the social/human sciences (following Latour's challenge to think beyond the nature/society divide pervasive in social/human studies), ${ }^{99}$ and to articulate the links between the experience of human community and ecological theories about resilience that Shawville's persistence as a community illustrates. It then turns to the relationship between particularity and community resilience, a relationship rooted in the role of particular place/communities as irreplaceable sites of meaning-making. The final section addresses Troughton's call for the development of operational structures and policy that would support the resilience of rural places. ${ }^{100}$ It ends by returning to the vital significance of particularity.

99 I return to Latour later in this chapter. His ideas are first introduced on page 10.

100 I refer to Troughton's 1995 appeal to the Canadian Association of Geographers discussed on page 9. 


\section{Resilience Theory Re-stated}

In the introduction to this work I claimed that examining and interpreting a community of people using tools and analogies borrowed from environmental science would prove both relevant and constructive. ${ }^{101}$ I argued that making use of environmental categories to think about social systems "endogenizes" (Pritchard et al. 1998) them within the scope of 'nature', marrying human activities and the functioning of the biosphere. I am convinced that this "re-coupling" (Folke 2009) is a vital step in thinking about both the source and the value of community resilience. Using vocabulary and constructs from ecology to think about ourselves is especially constructive because it helps us to think past the societal assumptions that weight terms like change, adaptation, and progress with teleological import. My intent in the overview of resilience theory that follows is to make clear the links between its insights vis-à-vis what is required for resilience, and the applicability of those insights to enhancing the resilience of human communities.

The understanding of resilience that Holling (1973) posited responded to what he saw as a paradox in environmental management practices; their very effectiveness seemed to precipitate system collapse (Holling 1973:18-21, Gunderson et al. 1995:7). ${ }^{102}$ In the name of sustainability, ecological systems were being managed to minimize disruption and maximize predictability. As Gunderson (2000) explains, "the goal of technologically-based resource

101 Although the models Holling (1973) designed can be seen to be descriptive (and therefore lacking in explanatory capacity) I make use of them as a basis for my account of resilience in Shawville, arguing that the characteristics they describe as inherent to resilient ecological systems are also present in resilient social systems. I have sought to demonstrate that these characteristics are, in fact, necessary to resilience. While Holling (1973), Gunderson (2000), Gunderson and Holling (2002), Walker and Salt (2006) inter alia 'describe' how resilience operates in their models, I take the models a step furcher and use Shawville as a case study to 'explain' how community resilience operates in practice.

102 Ludwig (1996) cites the success of the "Smoky the Bear" campaign which proved so effective in limiting the number of forest fires that the eventual result was "devastating". Debris build-up on the forest floor meant that when forest fires did happen, they were much bigger and much harder to contain than they had been when debris and dead material had been cleared more regularly. Ludwig's example supports Holling's claim that managing single variables within a system makes it less resilient (186). 
management [was] to control external sources of variability in order to seek a single goal, such as maximization of yield" (2000:433). Holling observed that managing to control variability within ecological systems resulted in a more stable system, but with a reduced capacity for resilience. This realization led him to argue that a more productive strategy for environmental management would "maintain flexibility above all else" in the interest of "stay[ing] in the game" (Holling 1973:18). The concern of resilience theory would be to analyse the breadth of a given 'zone of equilibrium', to learn when and which movement is healthy renewal within a system, and how much disturbance a system can absorb before 'jumping' to a new state in an adjacent zone, becoming in effect a different system (i.e. ceasing to be itself, potentially ceasing to be at all).

Holling distinguished between stability, "the ability of a system to return to an equilibrium state after a disturbance such that a rapid return and little fluctuation equals stability" and persistence, which he defined as "the ability [of a given system] to absorb change and disturbance and still maintain the same relationships between populations or state variables" (Holling 1973:14). He advocated shifting the focus of ecology from maintaining the conditions for stability, to enhancing the conditions for persistence because, according to his observations, persistence was actually strengthened by instability (Holling 1973:2).

The realization that ebbs and flows in population numbers, food availability and rain fall are an essential part of ecological resilience challenges us to conceptualize equilibrium (in human communities as in ecological systems) not as a single, stable state, but as a wide, shallow basin within which a system makes adjustments and shifts its weight in order to maintain its balance. Every basin is surrounded by other basins, multiple potential equilibria with their own centripetal force (Gunderson 2000:427-8). The smaller the area of a given basin, the more constrained the fluctuations are within it, the more likely a system is to be pushed, or 
pulled (attracted), over its brink into a new state (Gunderson and Holling 2002:133).

Variability is one factor in maintaining the breadth of resilience; diversity is another (Gunderson and Holling 2002:84). There needs to be diversity both within the resilience basins, and between them. Folke (2006) points to the value of seemingly excessive diversity and even redundancy in supporting resilience. He writes,

[s]pecies that may seem redundant and unnecessary for ecosystem functioning during certain stages of ecosystem development may become of critical importance for regenerating and reorganizing the system after disturbance and disruption... variability in responses of species within functional groups to environmental change is critical to system resilience.

(Folke 2006:258)

Redundancy is a valuable asset to resilience, while efficiency, specialization and optimization can be seen to diminish a system's capacity for resilience (Gunderson and Holling 2002:27-8, Walker and Salt 2006:9). Walker and Salt argue that "[i]ncreasing efficiency (optimization) inevitably leads to a reduction in diversity" and the attendant loss of functional and response diversity limits resilience (2006:121).

There is also value in diversity between systems. In the case of human systems (and specifically the case of Shawville as a community) we saw the role diversity between particular place/communities played in supporting resilience. A sense of its own distinctness, its particularity, can be seen as crucial to the existence of Shawville's dynamic 'zone of attraction', the well-defined core and perimeter of its equilibrium basin. If we take the particularity of a community to be a specific function or alternative response within a community of communities representing a larger system we can understand the crucial role played by the existence of diverse place/communities with a range of experiences, assets, and response repertoires. Diversity to the point of redundancy enhances resilience. 
The role of diversity and redundancy in enhancing the resilience of ecological systems is readily transposed into the realm of human society as I have shown in this thesis. Their value has become increasingly obvious in the pervasive sense of crisis (even in the absence of actual disruption) in institutions and human systems where functional and response diversity (in the form of 'extra' workers varied approaches) have been stripped to a minimum in the interest of efficiency and accountability. Too little diversity (in workers and/or their methods) stretches individual functions and responses to the brittle end of flexibility where there is little room to move in response to a crisis. Adaptive capacity in human systems, argue Redman and Kinzig, "is enhanced by a rich social memory of alternative situations and responses... [note the echo of Folke above]... some social adaptations or cultural traditions may appear inefficient or "illogical" when viewed in the short term, but reduce risk and increase resilience in the long term" (2003: pages unnumbered). Uniformity and efficiency, especially when they limit the range of experience available to a community, and therefore its "repertoire of alternative responses" (Redman and Kinzig 2003: pages unnumbered), also inhibits a human system's capacity for resilience. Taken to its logical conclusion, this suggests that the resilience of humanity writ large also relies on the widest possible range of experience, memory and alternative responses (i.e. a plethora of particular place/communities).

In Shawville, the memory of seasonal and cyclical unemployment and the experienced usefulness of transferrable skills that have proven productive even in the absence of a largescale employer can be understood as equipping the community with forms of diversity and redundancy, especially as compared to centralization/specialization that relies (collectively) on a single employer, and (individually) on a single, specialized skill. The long social memory of people like Robert (who specifically referred to his space as a museum alive with his grandparent's stories) is rich in scenarios already lived, and responses already tested that constitute a repertoire of alternative actions. Read as a resilience strategy, even the 
inefficient "illogic" of resisting francization despite being part of a Québec 'Regional County Municipality' has meaning. It can be seen as a bid on the community's part to create and fill an independent niche, accessing and exploiting socio-political resources from the strong position of being distinct (a self-confident English-speaking community), rather than the weaker position of being one among many (and an insecure English-speaking community). ${ }^{103}$ As we have seen, close ties and proximity to the English-speaking Ottawa Valley were already part of Shawville's narrative. Prior experience made turning to the Valley to anchor a positive identity as exceptional, rather than excluded, an easy adaptive strategy to adopt.

We also considered at some length Holling's model of adaptive cycles, the name he gave to the episodic adaptations and adjustments made by a system within an equilibrium basin. The model depicts equilibrium as both less static and more contingent within space and time than previous theorizations had allowed for. In keeping with the distinction he made between stability and resilience, Holling illustrated equilibrium as a matter of accommodating constant change rather than the result of 'holding firm' to a static position.

Resilience theory posits change as inevitable, on-going and recursive. It is a cyclical phenomenon that includes phases of growth and consolidation and periods of disruption, reorganization and change. It occurs across scales, involving the interaction of fast local cycles with quick feedback loops (the lifespan of insects) and slow global cycles with response times that lag over decades (the lifespan of trees). Change is cyclical but not predictable, on-going

103 The Fur and Baggara of Barth's (1969) article, Ethnic Groups and Boundaries, illustrate a particular cxample of social identity based on living a particular lifestyle or performing from a particular script(26). Fur who acquire sufficient cattle give up their settled lives and take on the nomadic herder lifestyle and 'ethnic' identity of the Baggara. With too few cows to provide a livelihood Baggara settle down to farming as Fur. The Fur and Baggara "do not make up a stratified system" (27), and are distinguished predominantly by access to livelihood. This and ocher examples in Barth's study beg the question, "Why would anyone accept identification as an inadequate example of his/her kind if the possibility of being a good example of some other were an option? In this light Shawville's "stubborn" refusal to become identified as (inevitably inadequate) Québécois is understandable. 
but discontinuous. The nature and timing of any given disturbance to a system is significant. What happens, and where in its own cycle the system under consideration happens to be when it happens can influence how the system responds, and what form its reorganization and future trajectory will take (Gunderson 2000: 430).

Redman and Kinzig write that the "nested hierarchies" of cyclical adaptation "provide the memory of the past and of the distant to allow recovery after change occurs" (2003: pages unnumbered). This is most true when the disturbance occurs while the local system is growing or consolidating and when the disruption is buffered by continuity at larger and/or smaller scales. If the disruption itself is generalized, and the system is already mature (inflexible) or in a disturbed or re-organizing phase, the impact of any disturbance will be greater.

Gunderson observes that when an ecological (or social) system is disrupted in "a weakly connected state, random seedings can generate multiple trajectories, which then establish the exploitative path along which the system develops" (Gunderson 2000:431). In other words, "disturbance has the potential to create opportunity for doing new things" or for doing things differently (Folke 2006:253). ${ }^{104}$ Redman and Kinzig (2003) suggest that the form re-organization takes is driven by a tension between 'remember' and 'revolt', depending on whether the greater pressure exerted on the system from smaller and larger scale systems is to re-group according to a prior norm, or to reform in line with new constraints and exigencies. In the case of social systems specifically, memory and system connectivity are key to enhancing a community's ability to re-seed itself in its own image and adapt within its existing resilience basin rather than 'Alipping' to a changed state by following a different path (Redman and Kinzig 2003:pages unnumbered).

104 Note here the perfect openings for functional diversity (i.e. doing new things) and/or response diversity (i.e. doing the same thing in a different way). Without diversity/redundancy to provide options disturbance cannot be a positive opportunity, only a negarive disruption. 
Previous discussions in this work have already touched on the ideas of constant but discontinuous change, the crucial importance of timing, and the interrelationship of varied scales expressed within Holling's model of adaptive cycles. My study of Shawville's resilience provided illustrations of all three: cyclical change, matters of timing and interrelationship. Thinking about 'being' Shawville as a dynamic performance in which the script and the set are constantly re-negotiated and the cast must accommodate substitutions helps us to see the community as in motion, managing a shifting sense of itself while navigating changing societal norms. Handler's (1990) description of an identity or a community as an "event", and Trépanier's (2005) illustration of community identity forged against the tensions of peril, belonging, excentration, and renewal, also contributed to conceptualizing Shawville's collective identity as fluid, episodic and negotiated, a cyclical work of production and reproduction, of performance and negotiation.

As well as acknowledging the significance of when (where in the adaptive cycle) a disruption occurs, I drew on Polanyi's (2001 [1944]) insight to acknowledge the importance of how quickly the disruption precipitates change. He observed that the speed of change is as significant as the kind of change with which a system is confronted (Polanyi 2001:39). Timing becomes a crucial factor in understanding the impact of any given disruption. Shawville, I argued in Chapter Four, has been blessed with time and by timing. Being "left behind" socially and economically has contributed to the community's resilience by slowing the impacts of change at other scales sufficiently to allow time for adaptation and meaningmaking. Shawville has had time enough to absorb much of the change it has experienced into its own identity/ story, consolidating the community's capacity for resilience rather than scattering its resources in "seeding" new directions. 
Considering the impact on the community of such different events as the seizure of the Baltic in a distant European war (1800) and the birth of a nationalist movement on its doorstep (1960s) makes clear the interrelationship of events at various scales. The different nature of their impact also speaks to the significance of where in its own cycle of growth, consolidation, disruption and renewal the community was at the time. At risk of simplifying much more complex interactions of timing and scale I offer two facile examples. The British search for pine wood masts along the Ottawa River to replace the newly inaccessible Scandinavian timber happened just as 'Shawville' was forming. Incorporated into the system in an early organizing and growth phase those events set the community on a trajectory that lasted into the present. In contrast, the impact on the community of Québec's political and linguistic 'disruptions' have been relatively minor, mitigated by the community's ability to draw on collective memory and re-group in favour of continuity rather than being pushed to make significant reforms.

It is helpful to read Holling's summary of the findings in his 1973 paper with the connections between ecological and social systems drawn above clearly in mind.

The resilience and stability viewpoints of the behavior of ecological systems can yield very different approaches to the management of resources. The stability view emphasizes the equilibrium, the maintenance of a predictable world, and the harvesting of nature's excess production with as little fuctuation as possible. The resilience view emphasizes domains of attraction and the need for persistence. But extinction is not purely a random event; it results from the interaction of random events with those deterministic forces that define the shape, size, and characteristics of the domain of attraction. The very approach, therefore, that assures a stable maximum sustained yield of a renewable resource might so change these deterministic conditions that the resilience is lost or reduced so that a chance and rare event that previously could be absorbed can trigger a sudden dramatic change and loss of structural integrity of the system.

A management approach based on resilience, on the other hand, would emphasize the need to keep options open, the need to view events in a regional rather than a local context, and the need to emphasize heterogeneity. Flowing from this would be not the presumption of sufficient knowledge, but the recognition of our ignorance; not the assumption that future events are expected, but that they will be unexpected. 
The resilience framework can accommodate this shift of perspective, for it does not require a precise capacity to predict the future, but only a qualitative capacity to devise systems that can absorb and accommodate future events in whatever unexpected form they may take.

(Holling 1973:21)

The work of this research project has been to frame the "problem" Shawville's persistence represents within the context and terms of resilience theory. The image of equilibrium as a basin allowed us to think about resilience as a community's ability to manage adaptive cycles within the limits of a certain way of being, to accommodate inevitable but unpredictable change without "jumping" to another basin and a new state of being. Throughout this work we have considered the importance of an equilibrium basin wide enough to provide solid footing, with a core positive enough to exert centripetal force, and a perimeter rim defined enough to reinforce a sense of distinctness. We examined evidence of Shawville's vital, coherent core grounded by its wide footing as part of the Ottawa Valley. We considered its distinct boundary in the form of acceptable practice marking the limits of its current basin and lessening the risk of slipping from one state to another inadvertently. We saw that Shawville exhibits a secure sense of its own "distinctness" sufficient to support the community's particularity. Vocabulary and analogies borrowed from resilience theory have proven valuable in analysing Shawville's persistence as a community in light of the factors that support resilience in ecological systems.

\section{Latour's Challenge}

In using ecological models to think about community resilience I have attempted to think past the false divide between people and nature. My goal has been to consider a human community as an example of a system similar to any other ecological system and in doing so, to take up Latour's call for a new kind of social science. In this section I turn to the work of 
resilience theorists who study social-ecological systems, and other scholars who explore the impact of human activities (and the ideas that support them) on the environments we exploit and on which we rely. With Latour, I argue that it is not enough to think about the role of human interference as if human beings were not inherent to the natural world.

Resilience scholars who consider social-ecological systems (SESs) in their research, recognize the ubiquitous presence of human impacts and interventions in natural systems and cycles. A social-ecological system, explains Gallopin, "includes societal (human) and ecological (biophysical) subsystems in mutual interaction". Such systems, he claims, are "non-decomposable", the human and the 'natural' cannot be untangled one from the other (2006:294). Folke, in an editorial written for Global Environmental Change (2009) writes,

It should by now be quite obvious that human societies are embedded in the dynamics of the biosphere and ultimately dependent on the capacity of the living environment to sustain development with essential ecosystem services... The scale and speed of human actions have expanded toward globally interconnected societies that are involved in earth processes at all levels.

(Folke 2009:1)

While the above quotes clearly acknowledge the interrelationship between human activity and the 'natural' world they both leave room for distance or distinction between them, as if human beings are not quite natural, as if we are dependent on but foreign to the earth's biosphere.

Instead I argue, as Folke writes elsewhere, that "the delineation between social and ecological systems is artificial and arbitrary" (2006:262). I imposed the vocabulary and assumptions of an ecological model onto the human community considered in my study in order to think about those assumptions in relation to us. Acknowledging that people are neither separate from the natural world nor exempt from the conditions that effect and govern it is the first step toward (re)membering ourselves as one species among others. I argue that it will also be the first step in strengthening and/or building resilience for both people and planet. 
In Chapter Five I called attention to what resilience theorists have described as the biggest challenge in incorporating human systems into their work, the human need for meaning. In that context I discussed the critical role of meaning-making as a limiting factor in the resilience of social systems. I relied on Trépanier's concept, refondation, to illustrate the relationship between meaning-making and the threshold of a community's resilience basin by conceptualizing the poles (tensions) from her model as guy wires stretching and securing the perimeter of its "zone of attraction" (just as guy wires stretch and secure a tarpaulin or tent). ${ }^{105} \mathrm{I}$ will return to the importance of meaning-making as part of the discussion of particular places as sites for the production and interpretation of meaning below. Here, I want to point to the drive for meaning, and the cognitive capacities that underlie it, as part of what makes the social component of social-ecological systems seem so unlike strictly ecological studies. As Folke explains, our (human) capacity for abstraction, planning, and technological development allow us to "transcend constraints" within a single system and "mask environmental feedback" about immediate impacts. Even serious shortages within our immediate environment can be "subsidized from a larger scale" and thus hidden behind a façade of plenty (Folke 2009:1). These abilities make the social component of socialecological systems seem very different indeed. Dangerously, we have interpreted the seeming difference as an actual divide that sets human activity somehow apart from the natural order and its constraints.

Latour challenges us to do more than see through the false bifurcation of the natural and the social to recognize that with the deepening ecological crisis, "Nature as an organizing concept (or, rather, conceit) is gone" and was not 'real' to begin with (2010:479). In a keynote lecture to the British Sociological Association Latour declared, "we are finally freed from a narrative that never accurately described what happened during the global expansion of humans

105 See explanation on page 100 and illustration on page 101. 
anyway" (2007:5). His claim is that "we have always been living through a completely different history than the one we kept telling ourselves", one in which we have become more and more vulnerable within the workings of the world around us, rather than one in which we have become detached from our "cumbersome ties" to nature (2007:3). If we are now free of this illusion it is an uncomfortable freedom, one that compels us to construct a new narrative to make sense of the newly recognized fragility of our situation. Latour writes that the challenges of our newly acknowledged attachment call for a new kind of scholarship. He advocates specifically a move from social science to what he calls "earthly sciences", arguing that the "radical new task" of the new discipline will be to expand the notion of the 'social' to that of 'associations', making room to recognize relationships between the social and the non-social, the multiple interconnections binding humans to ecological systems (2007:34). The "whole attention" of earthly sciences, argues Latour, "should shift to the modes of connections" (2007:7) because connections are what we have to work with in making sense of our reconfigured world.

Given the importance I attributed to the role of relationships in grounding and supporting Shawville's resilience I want to highlight for a moment Latour's insistence that they are significant enough to ground and launch a new field of study. He claims that the key to deciphering our future prospects lies in studying relationships we have thus far taken for granted (2007:3). It is interesting to note that Mead's (1970) anthropological work on intergenerational relationships also advocated looking to connections as key in preparing for an unknown future. In what Mead called "pre-figurative societies" old patterns of behaviour, old attitudes and old expectations are superseded or lost with no indication of the expectations, attitudes and behaviours that will replace them. In contrast to 'postfigurative' societies in which people expect to live lives already mapped along traditional paths (1970:1-3), and co-figurative societies in which people learn newly emerging skills and 
procedures from their peers (Mead 1970:25) a pre-figurative culture is in the process of total reinvention. Mead argues that in such circumstances a culture must rely on transmitting to its children not "what to learn, but how to learn and not what they should be committed to, but the value of commitment" (1970:72). These three examples, Shawville's roots, Latour's new field of study, and Mead's pre-figurative society, all suggest that relationships (connections, commitments) are key to having solid ground under our feet as we negotiate the future. Relationships allow us to "place our feet firmly in midair" (Gunderson and Holling 2002:108).

Latour's challenge to move from social to earthly science involves acknowledging the place of human communities as embedded within, rather than as distinct from, the biosphere and its inter-relationships. Clearly, I did not undertake to study Shawville as a socialecological system (however interdisciplinary one sets out to be, a project is inevitably defined to some extent by where one begins - in this case the research began with people). Nor did I set out to express the multiple relationships between the people and the place from an environmental studies perspective. What I attempted instead was a compromise with Latour's challenge. I undertook to consider human relationships, the persistence of a social system, within the framework of an ecological model. I asked if the conditions for ecosystem resilience had any bearing on the well-being of human communities. The implication of my findings is that social systems can indeed be understood using vocabulary and analogies developed to interpret the workings of ecological systems. The 'fit' between social system and ecological model serves to 'endogenize' human beings as earthly beings, part of a single analytic framework, part of a single integrated reality. 


\section{The Value of Particularity}

In this section I take the discussion back to the critical significance of particular place/ communities as sites of meaning-making, and to the role of particularity in supporting resilience. I argue, based on the research findings I have presented, that it is ultimately Shawville's experience of and belief in its own distinctness and significance, the community's particularity, that give it the will and the capacity for resilience. In the introductory chapter of this work I described particularity as both an experience and a perception, lived and reflected through the unique and specific relationships within a place/community. I explored the role particular place/communities play in homo narrans important need and capacity to make sense of the world by constructing meaning. Resilience, understood as a community's ability to navigate adaptive cycles without abandoning its existing form, relies on the community's capacity to accommodate change within a meaningful narrative. Meaning is required for resilience. Particularity is required for meaning-making.

The discussion in Chapter Three dealt at some length with the idea of place as a social product: the web-like pattern of our comings and goings through space (Lefebvre 1991), the sedimented outcome of history and relationships between places (Brodie 1990), and/or the result of struggle over the 'writing' and mapping of places in space (Ó Tuathail 1996). Each of these concepts acknowledges the human impress in the production of unique particular places. Despite expectations, the need for such places to ground identity and for identities in which to anchor ourselves has not proven to be something people have "grown out of" as modernity matured. Instead, as Appadurai points out, the more particularity has been treated 
as a disease to be cured by inclusion in the project of modernization, ${ }^{106}$ the more it appears to be an iatrogenic affliction, as often caused by modernization initiatives as it is cured by them because communities feel the need to push back against the experienced pressure to change form (Appadurai 1996:141). In the next few pages I turn to Cohen's work in order to conclude my discussion of the vital role asserting distinctness (particularity) plays in the construction of collective identities (communities), and in enhancing their resilience.

Cohen's description of "community" reflects the complex mix of experience and ideation that we express in everyday conversation. He writes that, "When the inhabitants of [a community] talk of 'their community', they refer to an entity, a reality, invested with [profound] sentiment (1985:13)... a resource and repository of meaning, and a referent of their identity" (Cohen 1985:118). Community, he claims, encompasses "kinship", "friendship", "domicile", and "modes of life, love and death; it is the whole person" (Cohen 1985:107 emphasis original). Cohen is careful to state clearly that while the social mores and processes of everyday life are full of symbolic import, they do not reflect a consensus so much as "something to think with" (1985:19), akin to Handler and Segal's (1990) description of social norms as a "vocabulary" that allows for negotiation, a beginning rather than an end to dialogue. Rather than a closed set of meanings, the constructs and symbols of a community's shared vocabulary "provide people with the means to make meaning" (Cohen 1985:19). The distinction is important. The shared vocabulary allows for the flexible re-negotiation of symbols (and what counts as a symbol) that is vital to appropriating, accommodating and otherwise adapting to changes both within and outside the community. The corollary, of

106 Ignatieff (1993), for example, distinguishes between ethnic nationalism and civic nationalism - the first an identity grounded in primordial, pre-modern history, the latter in enlightened liberalism and a view to the future. While it is impossible to defend the atrocities and radicalism so often associated with 'ethnic' identifications and exclusions (though particularity as I am using it is inarguably close to the same set of ideas), I am also unwilling to defend Ignatieff's blanket condemnation. There is too much of a too familiar arrogance in declaring that what constitutes "mature" behaviour is "my" behaviour as a Western "liberal" (educated and urbane) man. 
course, is that without a shared vocabulary of symbols negotiating meaning becomes heavy work (whether within our own nested communities or between them). When Pat celebrated the sense of "homecoming" in "finding her lost tribe" in Shawville, or summed up her sense of being "at home" visiting Scotland in the happy exclamation, "I get these people", she was pointing to the profoundly restful feeling of settling into a shared frame of reference, of both understanding and feeling understood. This capacity to reflect us back to ourselves, I believe, is what invests our communities with such affective power (for good or ill).

Some cultural mnemonics (Cohen calls them 'condensation symbols') bear disproportionate weight, supporting the form and expression of a community's particularity. Such condensed symbols serve as heavy cultural anchors against transforming forces (weighting the adaptive cycle towards "remember" and away from "reform"). Like Shawville's touchstone identification as "shantymen" and loggers (a significant identity marker despite its distance from current reality) these symbols 'work' because they are "infused with timelessness" (Cohen 1985:102). By representing "the valued past and the continuity of tradition even in the much changed present" they reassert "the cultural integrity of the community in the face of its apparent subversion by the forces of change" (Cohen 1985:103). In the absence of such weighty symbols "reform" becomes more likely. The push or pull exerted by adjoining "zones of attraction" is harder to resist in the absence of a counterweight.

Shawville's resilience stood out because it seemed to me exaggerated, a tour-de-force given the mixture of socio-economic, linguistic and political factors militating against it. The community had every reason to abandon the effort and move to Renfrew, or allow itself to "flip" states to a neighbouring resilience basin and settle into a new equilibrium as a francophone community in rural Québec. As Cohen observes, "not all communities are so resilient, and not all make such a determined and vibrant response to change [disturbance]. 
Many become deserted, culturally and/or demographically... or are wholly transformed, losing their sense of themselves" (Cohen 1985:104). There have been some attempts to explain the sort of "vehemence and assertiveness" Shawville demonstrates, though few, according to Cohen, have studied resilience in local communities (Cohen 1985:104). Current explanations suggest that the drive to assert particularity is much more than a desire to draw attention to a disadvantaged or subordinate position vis-à-vis the other, or the whole (Cohen 1985:104). The "political assertion of cultural difference" (i.e. ethnicity) and/or a "well-developed collective self-consciousness" can also be understood as an affirmation of agency. In Shawville, I argued, it reflects the deliberate choice to be exceptional rather than excluded.

Given the reflections presented in this work I suggest that the will to assert particularity is part of our instinct for survival. Particular place/communities provide for the meaningmaking we as human beings require. 'Home' places reflect us back to ourselves and acknowledge/challenge/validate the meaning we as individuals construct. Particularity supports our will and capacity for resilience, individual and collective. The safe-guarding of particularity ensures an on-going diversity (even redundancy) in the repertoire of thoughts, actions, and responses to disturbance available to the human community writ large.

\section{Troughton's Chállenge}

Before I bring this work to a close I want to reconnect briefly with the challenge Troughton (1995) set before his colleagues in his presidential address to the Canadian Association of Geographers. In that address he pointed to the precipitous decline of rural community well-being and called for the assessment of "current operational structures" and "a search for models which might better realize [rural community] potential and halt its decline" 
(300). New models were necessary he felt, because "the recent, sudden, and at times absolute decline, including retreat and abandonment, represents more than a decline relative to urban growth and dominance, but absolute loss to national, regional, and local community systems". Troughton saw "rural demise" as "antithetical to emerging concepts of sustainable development" and, therefore, a trend that needed quick attention (1995:291). Attention to "what has occurred, what has been lost, and what might be regained" (1995:301) would, he felt, generate attachment to the rural landscape, which would in turn inspire new perspectives and policies. Note that here again relationship/connection/commitment is considered key to creative solutions.

The emptying out of rural towns and villages, their transformation from particular placel communities into indistinguishable leisurescapes, or their amalgamation into larger and larger aggregates in response to the economic demands and opportunities of "accelerating globalisation... exacerbate[s] the already precarious situation" of many rural communities (Wilson 2010:365). Wilson (2010) writes that although its impacts differ from one context to another across space the general trend of globalisation is toward undermining function and response diversity (which he calls "multifunctionality") thus limiting the diversity essential to resilience. (2010:371). In contrast, the resilience of the whole system would be enhanced by policy and practices that encouraged and supported maximizing variability and diversity.

A development mandate to support rural communities, then, would look equally to their economic, social and environmental health, concerned to enhance their well-being in each of those varied domains. Its goal would be to ensure the presence of function and response diversity within the system to 'redundant' excess. Such a mandate would, after all, be concerned with "not only [the community's] adaptation to current conditions and in the 
short term, but [with] how to achieve transformations toward more sustainable development pathways" (Folke 2006: 263) in the long term. Flexibility and diversity within the system (both at the micro scale of each particular place/community, and, perhaps even more vitally, at the macro scale between communities) would ensure that disturbance opened up opportunities for creativity rather than threatening the system with collapse. The capacity for resilience requires the widest possible repertoire of responses to disturbance. It requires the existence of "particularities".

\section{Conclusion}

The stories that I collected in Shawville paint a vivid picture of community, a particular place and people. There are quiet strains of the many Shawvilles lived in the individual experiences of the story tellers, and enough shared threads and themes to bind those experiences together into a collective identity. The tenor of those stories made me rethink the questions that shaped my analysis. As the interviews progressed, focusing on change, and trying to tease out how change had been experienced and deliberately managed in Shawville seemed to approach the question of the community's resilience from the wrong direction. I designed my research project to ask what tools (resources, circumstances, and social organizations) the community had used to navigate change, and how those tools had been mobilized to help Shawville keep its balance on the shifting ground within its "zone of attraction". Over time my questions took on a different meaning. I began to see the community's resilience as the result of "being" rather than "doing", leading me to claim that Shawville's resilience as a community has been less dependent on access to useful tools and strategies than on the relationships that ground them, defining the community as a community, and making Shawville specifically and particularly Shawville. 
Deep roots, a distinct self-image, the ability to make meaning, and sufficient time to integrate change, these are the features this study has identified as contributing to Shawville's capacity for resilience. These features have served to support Shawville's resilience up to now. My concern is that they are all, in one way or another, compromised by the current political and socio-economic climate. The exigencies and assumptions of the globalized market-place value mobility over roots, uniformity over particularity and push the rate of change to a new and frantic pace.

The ambition of this work is not to make predictions about Shawville's particular future, but to argue that such communities are currently vulnerable and to make a case for preserving the rich particularity of rural places as essential to preserving their resilience independently, and our resilience collectively. I argue that enhancing the resilience of particular place/ communities needs to be recognized as what Wilson calls a "moral" goal (2010:376). Particularity safe-guards diversity and provides the conditions for meaning-making. It is vital to our (human) capacity for resilience.

I chose to investigate community resilience in Shawville because its specific circumstances as an English-majority community in Québec made its persistence conspicuous. Aside from that particular feature, Shawville's situation is not unlike that of many small, rural, resourceand/or agriculture-based communities across Canada. I believe that a similar interrogation of many such communities would reveal a similar set of features supporting their resilience. Comparative research to corroborate this claim would be an obvious 'next step' in this project.

Shawville has proven to be a productive and interesting case study. It has served well as an example of community resilience, and of the strength inherent in being a community. The 
people who spoke to me about their "home", its past, its present, and their place within it, expressed a profound sense of belonging, and a deep pride in being who and where they were. They convinced me of their distinct and significant place in the world. My work has been to articulate that significance in terms of the invaluable role of particularity in motivating and sustaining resilience. It has been my privilege to express on their behalf the importance of being Shawville. 


\section{Appendix A}

\section{Carleton \\ U N I V E R I T Y \\ Canada's Capital University}

\section{Initial Contact Script (telephone)}

My name is Lyndal Neelin. I am a PhD candidate in the School of Canadian Studies at Carleton University.

I am contacting you in your capacity as to ask for your help with the research project that will become my doctoral dissertation. I am studying community resilience, and using Shawville's story to test and to illustrate some ideas about how communities manage change. Shawville is obviously an excellent example of resilience, and community. I am interested in the period between the PQ victory in 1976 and the Mill closure in the fall of 2008 . I want to learn from you which changes, among the many social, economic and political changes Shawville has experienced since 1976, stand out in your mind. Which moments and events do you remember, and what do you remember about them? How did the community rally to manage and cope with the new situation? I am particularly interested to learn what strategies and resources you think were most helpful to the community in managing the change. The objective of this research is to offer an analysis of the present and future capacity for resilience of Shawville specifically, and small town, agricultural Canada more generally.

I hope that you will agree to an interview. I will need something close to an hour and a half of your time. I have some questions prepared, but we will keep the conversation as informal as possible. I will, of course, take notes, and, with your permission, I would like to record the interview as well. I will need to ask you to sign a consent form before we begin.

We can meet at your office, or we can arrange to meet in town, perhaps at Ruth's 'Café $349^{\prime} . .$. confirm day and time...

Many Thanks 


\section{Appendix B}

\section{Carleton \\ U N I V E R S I T Y \\ Canada's Capital University}

\section{Semi-Structured Interviews - Sample Questions}

1. Have you reviewed the informed consent form? Do you have any questions? Are you prepared to sign it?

2. How would you describe the community here in Shawville? What would you say were its distinguishing features? What is most important to you about the community?

3. Please tell me a little about your place in the community. How did you come to hold this particular office/position? How long have you lived in Shawville? Do you identify yourself as from Shawville? How do you identify yourself?

4. Have you lived away from Shawville, or ever been tempted to leave the community? What tempted you? Why did you stay? What brought you back?

5. Thinking back through recent decades - since the 1976 election, for example - tell me a little about how life here in Shawville has changed. - Social values? Economic opportunities? The political scene? Which of the changes you have described seems most significant?

6. Can you tie these changes to particular events or experiences here in the community? Did something in particular happen to make you conscious of the change? (By the time the interviews are conducted I will have a ready list of events to posit as having been significant - referenda in 1980 and 1995, English-language testing of all hospital employees in 1984, establishment of CEGEPs in the late 1970 s...).

7. What do you remember about that time? Why does it stand out for you? Is it because of how you felt, or because of how people responded, or because it changed something significant about the community?

8. What was different after that event? What things did not change? How did you feel about the things that changed? What about the people around you, how did they say they felt?

9. What sort of actions/reactions were considered? By the community? By those in authority - Town councilors? Politicians? Business leaders? Opinion makers?

What action was taken? How was the choice explained? Who explained why that particular course of action was chosen?

10. Is there a question I have missed? Anything that you would like to add? Anything that occurred to you while we have been talking?

Many thanks!! 


\section{Appendix C}

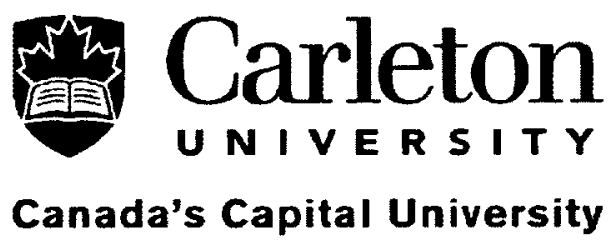

\section{Letter of Consent}

Thank you for agreeing to be part of my research project. What follows is a brief description of my research topic and goals, and the contribution you will make to my dissertation work. Please read it carefully, and sign your name only once you feel satisfied that I have answered all your questions.

My doctoral dissertation explores the ability of a social system (a community) to accommodate change without changing its own character, an ability I am calling 'resilience'. Shawville is a compelling example of community, adaptability and resilience. The community has weathered considerable upheaval in recent decades, from the PQ victory in 1976 to the last mill closure in the fall of 2008. My goal in this interview is to learn from you which changes, among the many social, economic and political changes Shawville has experienced since 1976, stand out in your mind. Which moments and events do you remember, and what do you remember about them? I am particularly interested to learn what strategies and resources you think were most helpful to the community in managing change. The objective of this research is to offer an analysis of the present and future capacity for resilience of Shawville specifically, and small town, agricultural Canada more generally.

With your permission I will record this interview. It may prove helpful as the project continues to transcribe the recorded text. The recording/transcription and my notes will be analyzed and possibly quoted in my dissertation. They will be saved as computer files for an indefinite amount of time and may be included in further research on related topics. Parts of the research will likely be presented publicly at academic conferences and submitted for publication in academic journals. Every attempt will be made to store and secure data appropriately according to evolving standards and methods.

I will not be able to promise anonymity or confidentiality to participants in this research. I will need to name Shawville as my study site since the particular location and situation of this village is significant to my analysis. You are, of course, under no obligation to participate in this interview and may, at any time, end our conversation and/or request that the information you have provided be destroyed.

Copies of the all-but-final draft of my dissertation will be made available to those participants who are interested in seeing their words where I have put them, and verifying my interpretation of them. 
If you have any questions or concerns regarding this research project please contact:

Lyndal Neelin (researcher) 15 Aylmer Rd. Bristol QC J0X 1 G0

Ineelin@connect.carleton.ca
Professor Antonio Gualtieri, Chair

Carleton University Research Ethics Committee Office of Research Services 1125 Colonel By Drive Ottawa ON K1S 5B6 Tel: 613-520-2517 e-mail: ethics@carleton.ca

I understand the goal of this

research and the role of my participation in it. My signature below indicates that I consent to participate:

Participant's signature

Date 


\section{Appendix D}

The Equity: March 24, 2010

RESILIENCE | LYNDAL NEELIN

\section{Exploring Shawville's Resilience}

This is the first entry in what I hope will become a conversation between you, The Equity's readers, and me, Lyndal Neelin, a PhD student at Carleton University. This column is an important piece in the research project that will become my doctoral dissertation. My research looks at the ability of a community to accommodate change without changing its own character, an ability I am calling 'resilience'. Shawville, a great example of community resilience, is my case study.

The first part of my research asks how individuals and communities hold on to a sense of their identity and manage day-to-day decisions during times of change. I want to identify the strategies and resources communities make use of to keep their balance when what counts for 'common sense' changes. The second part of my project examines the potential costs of our ability to adapt. Social and environmental scientists who study resilience are concerned that some of the things we do to manage change make us less flexible and more vulnerable in the long run. I want to explore the possibility that how we manage change (the resources and strategies we use) might be making us (individuals, communities, and species) less resilient over time.

Over the next few weeks I am going to ask you about the many social, economic and political changes Shawville has experienced since 1976. I will ask which changes stand out in your mind as being the most significant; which moments and events you remember, and what you remember about them. I am particularly interested to learn what strategies and resources you think were most helpful to the community in managing the events that stand out for you. The objective of this research project is to offer an analysis of the present and future capacity for resilience of Shawville specifically, and small town, agricultural Canada more generally.

The first question I'd like to hear your responses to is "What makes this community (Shawville or The Pontiac) distinct from other small towns and rural communities"? Often the media make it sound as if all small towns are pretty much alike. I would like to hear your thoughts about what stands out for you about this community in particular. Shawville boosterism is okay, but answers that relate to what makes Shawville Shawville are obviously more helpful than answers that talk about why Shawville is the best.

I encourage you to write directly to The Equity. Your responses will be published (in line with The Equity's standard policy re: authorship, editing and space) so that they can become part of a dialogue with other readers. Making your responses public may jog someone else's memory, or encourage someone else to participate too. If you are uncomfortable with being part of such a public discussion please consider contributing to my online forum, www.shawvillestudy.blogspot. com or writing directly to me at Ineelin@connect. carleton.ca

I would also be happy to receive your thoughts through the mail: Lyndal Neelin, 15 Aylmer Rd., Bristol QC, J0X 1 G0.

Whether your submissions are published in The Equity or not they will become part of my data collection. They will be analyzed in my research and possibly quoted in my dissertation. All the data will be saved for an indefinite amount of time to allow for further research on 
related topics. When the time comes I will make copies of the all-but-final draft available to those participants who are interested in seeing their words where I have put them, and verifying my interpretation of them.

In compliance with the policy of the Carleton University Research Ethics Committee I must state clearly that I will not be able to promise anonymity or confidentiality to participants in this research. I will need to name Shawville as my study site since the particular location and situation of this village is significant to my analysis. I must also state clearly that you are under no obligation to participate in this forum and may, at any time, request that the information you have provided be destroyed. 


\section{Appendix E}

The Equity: April 7, 2010

RESILIENCE | LYNDAL NEELIN

\section{Shawville's Resilience Narrative}

In last week's column, the first in this 'conversation' exploring Shawville's resilience as a community, I asked you to think about what it is that makes Shawville distinct. I hope that you will share with me, and with The Equity's wide readership anecdotes about Shawville that illustrate its special character and define its community. Please send your thoughts and anecdotes in to the paper, or consider posting a phrase or a few adjectives on my 'blog'.

This week, I am asking you to respond to some of the data I have been collecting. I've spent some time reading through The Equity's archives. It's a slow job, because the paper is rich in community stories, and details about local events and opinions. Most recently I read through the papers from 1976 , the year of the Parti Quebecois victory in the provincial election. I knew the election, and the victory, were coming of course, so I was surprised by the absence of election related content in the weeks leading up to November 15 . There were some signs of English/French tensions, mostly focused on Bill 22 which was clearly seen as a major imposition, and on interaction with Québec bureaucracy, an ongoing frustration. There is no hint in the paper of big changes in the offing. In September of 1976 The Equity even began to carry one page of French content, explaining that the inclusion was a better reflection of the region's population.

On November $17^{\text {th }}$, the election results are reported, polling station by polling station. Shawville's vote was almost evenly divided between the Union Nationale (448 votes) and the Liberals (408 votes). It seems the Liberals did not hold a monopoly on the federalist vote. That was my second surprise. The third was the editorial on page two of the same paper that read: "The election is over for another time so we can go back to our daily routine and try not to notice what happened". The editorial writer pointed out that Lévesque had only $40 \%$ of the popular vote, Canadian stock markets did not seem worried, and all would well. Two weeks later, the same editor initiated a conversation about "the problem of keeping Pontiac County in Canada" (Dec.8:p.2), and was chided for being ready to abandon ship rather than challenge "René". The letter to the editor appeared, unusually, on the front page and read: "We must say, "O.K. René, you have Québec, but in getring it, you got us. Now what are you going to do?" we must not be content to be cut off from the rest of the province, or to live in a Canada without Québec" (Dec.15: p.1). What do you remember about the $P Q$ victory? Was it quickly forgotten, or did you hear conversations about moving away, or moving back in order to work against separation? Did it make the Québec/Ontario border more real, as much of my research suggests? I am interested in your opinions and impressions.

I encourage you to write directly to The Equity. Your responses will be published (in line with The Equity's standard policy re: authorship, editing and space) so that they can become part of a dialogue with other readers. Making your responses public may jog someone else's memory, or encourage someone else to participate too. If you are uncomfortable with being part of such a public discussion please consider contributing to my online forum, www. shawvillestudy.blogspot.com or writing directly to me at Ineelin@connect.carleton.ca I would also be happy to receive your thoughts through the mail: Lyndal Neelin, 15 Aylmer Rd. Bristol QC, J0X 1 G0. 


\section{Appendix F}

The Equity: April 18, 2010

RESILIENCE | LYNDAL NEELIN

\section{Exploring Shawville's Resilience}

This is the third in a series of columns exploring Shawville's resilience as a community. I am studying Shawville as a particular case of community resilience in order to understand the tools and resources communities make use of to manage political, economic and/or social change. These newspaper columns, and your replies, are part of the research project that will become my doctoral dissertation.

In the introductory article (March 24) I asked you what makes this community (Shawville, or 'the Pontiac') distinct from other small towns and rural regions. I would like to be able to support my own impressions with your anecdotes and examples. The second installment (April 7), asked you to think back to the PQ election victory in 1976. Much of my research suggests that the Québec/Ontario border only became 'real' after the Parti Québécois came to power in Québec? I am interested to learn whether or not you would agree. Did it make a difference to you that you were living in Québec before that election? Did it make a difference afterwards?

I am still looking at the time period between 1976 and the first 'sovereignty-association' referendum in 1980 . The academics I've been reading all agree that Québec's English-speaking communities were too scattered and too diverse to consider themselves a group before they felt threatened by the PQ's agenda and the looming referendum. After the PQ election there was a lot of work done to form a united front in order to contest the new language laws, especially as they related to schools and signs. A sociologist named Gary Caldwell argued that while organizations like Alliance Québec offered the obvious advantage of strength in numbers, a more effective response to Québec's growing nationalism might have been to concentrate on distinguishing Québec's Englishspeaking communities from the continent-wide culture of English-speaking North America. He was convinced that without a clear claim to a particular identity in Québec, English-speaking Quebeckers would continue to be seen as oursiders in Québec, by the rest of English Canada and by the Québécois. It seems obvious that Shawville (and the 'Old' Pontiac) have a very strong claim to a particular identity with deep roots on the north shore of the Otrawa River. What is less clear studying Shawville's history is whether you (The Equity's readers) would say those roots were in Québec, or the Ottawa Valley, or somewhere else. Do you think of yourselves as Anglo-Quebeckers? Does being an Anglo-Quebecker connect you with other English-speaking communities in Québec? Or does it reflect your connection with this piece of geography?

I encourage you to reply directly to The Equity. Your responses will be published (in line with The Equity's standard policy re: authorship, editing and space) so that they can become part of a dialogue with other readers. Making your responses public may jog someone else's memory, or encourage someone else to participate too. If you are uncomfortable with being part of a public discussion please consider contributing to my online forum, www.shawvillestudy.blogspot. com or writing directly to me at lneelin@connect. carleton.ca . I would also be very happy to receive your thoughts through the mail: Lyndal Neelin, 15 Aylmer Rd. Bristol QC, J0X 1 G0. 


\section{Appendix G}

The Equity: May 12, 2010

RESILIENCE | LYNDAL NEELIN

\section{Exploring Shawville's Resilience}

This is the fourth in a series of columns exploring Shawville's resilience as a community. The questions I am asking, and your replies, are part of the research project that will become my doctoral dissertation. My goal in asking these questions is to test my own impressions against your anecdotes and experiences. I am grateful to have received several very helpful responses, borh printed in the paper, and via e-mail. Thank you!

In the first article (March 24) I asked you what makes this community (Shawville, or 'the Pontiac') distinct. The second installment (April 7), asked you if the border between Québec and Ontario became more 'real' after the Parti Québécois came to power in Québec. My third question (April 18) was whether you felt an Anglo-Quebecker identity existed before the 1970s, and whether you identify yourselves as Anglo-Quebeckers, or as part of the Ottawa Valley, or in some other way altogether.

This week, in my reading and conversations, the long-standing issue of mobility kept surfacing. Sometimes we were talking about the sheer number of kilometers of road we maintain and plow; sometimes about the distances we travel to work or study; sometimes about what we might do to draw mobile others (and their tourist dollars) here. In Suffering from a Want of Communication: $A$ history of Transportation in Pontiac County
(2000) Gordon Graham writes, "The key to developing the potential of any region .... is the continual improvement of its transportation system"(53). I want to suggest that in recent years we have not only improved our ability to move around, but have also changed our whole attitude toward mobility and distance. What was once considered a long journey into town, or to the city, has become an every day event. 'Here' and 'there' no longer seem very far apart. How has our changed relationship to mobility and distance affected life in this community? What sort of plans are we making in response to the rising cost of mobility?

I encourage you to reply directly to The Equity. Your responses will be published (in line with The Equity's standard policy re: authorship, editing and space) so that they can become part of a dialogue with other readers. Making your responses public may jog someone else's memory, or encourage someone else to participate too. If you are uncomfortable with being part of a public discussion please consider contributing to my online forum, www.shawvillestudy.blogspor. com or writing directly to me at Ineelin@connect. carleton.ca . I would also be very happy to receive your thoughts through the mail: Lyndal Neelin, 15 Aylmer Rd. Bristol QC, J0X 1 G0. 


\section{Appendix $\mathrm{H}$}

The Equity: June 9, 2010

RESILIENCE | LYNDAL NEELIN

\section{Exploring Shawville's Resilience}

This is the fifth in a series of columns exploring Shawville's resilience: the community's ability to absorb change without changing its character. Your replies to these articles are part of the research project that will become my doctoral dissertation. My goal in asking these questions is to test my own impressions against your anecdotes and experiences. I am grateful to have received several very helpful responses, both printed in the paper, and via e-mail. Thank you! My findings will be both more accurate and more important because they reflect your experiences. It is important to stress that it is your impressions I need. I can get expert information from the experts. Only you can share with me your anecdotes and experiences.

I began by asking you to describe in your own words what makes this community (Shawville, or 'the Pontiac') distinct. In the next two columns I asked you to comment on two 'facts' that I have read in academic work about English-speaking Québec; 1) the border between Québec and Ontario only became 'real' after the Parti Québécois came to power, and 2) "Anglo-Quebecker" only became an identity in response to the PQ's language laws. In my last article, moving away from the issue of language, I asked you to comment on how changes in mobility and the way we experience distance have changed life in this community. Perhaps your increased mobility has changed where you shop, or work, or where you or your kids go to school?

In this article I want to turn to agriculture and ask you to comment on how changes on local farms have affecred the community in the past 25 or so years. The 'agriculture file' in the Shawville archives is full of clippings about mini-courses and information sessions for farmers, many of them responding to changes in technology and government regulations. A local farmer I spoke to confirmed that while regulation is not new, the amount of regulation and the centralization of policy making are increasing, and the quantity of regulation does represent a significant change that farmers have had to accommodate, in terms of both the cost of licenses and the time it takes to deal with paper work. The 'agriculture file' also reflects a good deal of experimenting with potential new enterprises: sheep, millet, grapes, hemp, hops, rice... I find myself wondering how much of the impetus for experimentation comes from inside the local farming community, and how much is driven by the structure and assumptions of rural development projects and agencies. To what extent are Pontiac farms tied to provincial and national policy agendas? How much autonomy do local farmers have? How much room to maneuver do individual farms have while they try to balance costs and opportunities, and manage risk?

I encourage you to reply directly to The Equity. Your responses will be published (in line with The Equity's standard policy re: authorship, editing and space) so that they can become part of a dialogue with other readers. Making your responses public may jog someone else's memory, or encourage someone else to participate too. If you are uncomfortable with being part of a public discussion please consider contributing to my online forum, www.shawvillestudy.blogspot. com or writing directly to me at Ineelin@connect. carleton.ca. I would also be very happy to receive your thoughts through the mail: Lyndal Neelin, 15 Aylmer Rd. Bristol QC, JOX 1G0. 


\section{Appendix I}

The Equity: July 14, 2010

RESILIENCE | LYNDAL NEELIN

\section{Exploring Shawville's Resilience: Ties with Ireland}

This is the sixth in a series of columns exploring Shawville's resilience: the community's ability to absorb change without changing its character. Your replies to these articles are part of the research project that will become my doctoral dissertation. Previous articles have asked for your impressions about what makes Shawville (or 'The Pontiac') unique, how the English-speaking community here was affected by and responded to the early upheavals of the PQ victory in 1976, the advent of language laws, and how changes in mobility and the practice of agriculture in the last decade or two have affected life here. My goal in asking these questions is to test my own impressions against your anecdotes and experiences. I am grateful to have received several very helpful responses, both printed in the paper, and via e-mail. Thank you! My findings will be both more accurate and more important because they reflect your experiences. It is important to stress that it is your impressions I need. I can get expert information from the experts. Only you can share with me your anecdotes and experiences.

I had the opportunity last week to talk about my research here in Shawville at the University of Cambridge in England. Cambridge recently celebrated its $800^{\text {th }}$ anniversary as a community of scholars. In the shadow of Cambridge's sense of time my claim that this community shares a long collective memory might seem somewhat hollow. In fact, it is not difficult to demonstrate or explain Shawville's sense of having a long shared past. Many of you have spoken to me about your parents, grand parents and even great grand parents as part of your sense of belonging here.
The sense of continuity in this place is strong. It is also possible in many cases to stretch that sense of continuity across the sea to Ireland and the shared experiences of emigration and settlement in the Ottawa Valley. One of the stories shared with me recently told of a husband and wife from Shawville who visited Ireland and found their separate ancestors lying side by side in the same village graveyard, clear evidence of continuing connections within the community over time and distance.

I want to test my sense that the community of Shawville (representing the English-speaking community in the Pontiac) has a collective memory and shared worldview coloured by its roots in Protestant Ireland, and the experiences of emigration and re-settlement. Stories told at family gatherings, experiences of "The Glorious $12^{\text {th }}$ and connections to the Orange Lodge, visits "home" to Ireland, or family connections across the Ottawa Valley will all be interesting and valuable in my research!

I encourage you to reply directly to The Equity. Allowing your responses to be published (in line with The Equity's standard policy re: authorship, editing and space) may jog someone else's memory, or encourage someone else to participate too. If you are uncomfortable with being part of a public discussion please consider contributing to my online forum, www.shawvillestudy.blogspot. com or writing directly to me at Ineelin@connect. carleton.ca . I would also be very happy to receive your thoughts through the mail: Lyndal Neelin, 15 Aylmer Rd. Bristol QC, J0X 1 G0. 


\section{Appendix J}

The Equity: August 2, 2010

RESILIENCE | LYNDAL NEELIN

\section{Strawberry Teas and Resilience}

This is the seventh in a series of columns exploring Shawville's resilience: the community's ability to absorb change without changing its character. Your replies to these articles are part of the research project that will become my doctoral dissertation. Previous articles have asked for your impressions about what makes Shawville (or 'The Pontiac') unique, how the English-speaking community here was affected by and responded to the early upheavals of the PQ victory in 1976, the advent of language laws, and how changes in mobility and the practice of agriculture in the last decade or two have affected life here. My goal in asking these questions is to test my own impressions against your anecdotes and experiences. I am grateful to have received several very helpful responses, both printed in the paper, and via e-mail. Thank you! My findings will be both more accurate and more important because they reflect your experiences. It is important to stress that it is your impressions I need. I can get expert information from the experts. Only you can share with me your anecdotes and experiences.

One of my recent conversations highlighted the seasonal round of local gatherings - strawberry teas, wild game dinners, and harvest suppers gatherings that affirm a sense of place and time and community in their rhythm and repetition. This community is rich in such events. Every issue of The Equity, past and present, reports on the successes of a recent 'happening', or announces some up-coming occasion, from fishing derbies to theatre nights. What interests me particularly about these gatherings is their continuity over time, the way in which they serve to measure time and connect the past and the present. Not long after we came to Shawville I spent a wonderful day 'putting up' beet salad with two dear friends who had been making beet salad together on a similar early-September day for forty years. While we worked, they talked, and I listened. They laughed about their earliest beet-salad-making days, and about the years with various configurations of their children helping or getting underfoot. The inevitability of ripe beets in the fall became a back drop for changing circumstances and enduring friendship. It is the same relationship between place and time and community that is affirmed in the ritual of strawberry teas in early summer, or Grandma's zucchini loaf at the cottage, or s'mores around the campfire...

Please send me your stories about community and food and gatherings. I am interested in both the rituals you still repeat, and the ones that have been lost. There is a great deal of history, particularly local and community specific history hidden in what we eat, and how and where we eat it.

I encourage you to reply directly to The Equity. Allowing your responses to be published (in line with The Equity's standard policy re: authorship, editing and space) may jog someone else's memory, or encourage someone else to participate too. If you are uncomfortable with being part of a public discussion please consider contributing to my online forum, www.shawvillestudy.blogspot. com or writing directly to me at Ineelin@connect. carleton.ca . I would also be very happy to receive your thoughts through the mail: Lyndal Neelin, 15 Aylmer Rd. Bristol QC, J0X 1G0. 


\section{Appendix K}

The Equity: August 25, 2010

RESILIENCE | LYNDAL NEELIN

\section{Have I asked the right Questions?}

This is the final entry in a series of columns exploring Shawville's resilience, a research project that will become my doctoral dissertation. Previous articles have asked for your impressions about what makes Shawville (or 'The Pontiac') unique. I have asked you to comment on how the English-speaking community here was affected by and responded to the early upheavals of the $P Q$ victory in 1976 and the advent of language laws, how changes in mobility have affected life here, and how the practice of agriculture in the last decade or two has changed. I have also asked for anecdotes that reflect the long continuity of relationships within this community, and it ties to this place. My goal in asking these questions is to test my own impressions against your anecdotes and experiences. I am grateful to have received several very helpful responses, both printed in the paper, and via e-mail. Thank you! My findings will be both more accurate and more important because they reflect your experiences. It is important to stress that it is your impressions I need. I can get expert information from the experts. Only you can share with me your anecdotes and experiences.
A very serious weakness with any research project is that the information that gets gathered is only as good as the questions the researcher thinks to ask. I began this project assuming that Shawville's longevity and persistence had to do with some combination of its location in the Ottawa Valley (and on the Québec / Ontario border), its economic base in agriculture, mining and logging (with cycles of employment and unemployment), and its socio-linguistic identity (predominantly Irish, Protestant and Englishspeaking). The questions I have asked, and the people I have spoken to, reflect this set of assumptions. Have I missed the real questions? If $I$ asked you what holds this community together what would you tell me? If you got to have the last word what would you want me (someone with the audacity to write about your community) to know?

I encourage you to reply directly to The Equity or consider contributing to my online forum, www.shawvillestudy.blogspot.com or writing directly to me at lneelin@connect.carleton.ca . I would also be very happy to receive your thoughts through the mail: Lyndal Neelin, 15 Aylmer Rd. Bristol QC, J0X 1 G0. 


\section{Appendix L}

\section{CHACUN DES PÔLES EXPRIME LA TENSION}

ENTRE DEUX OBJECTS

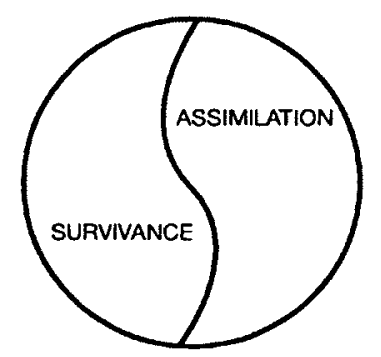

péril
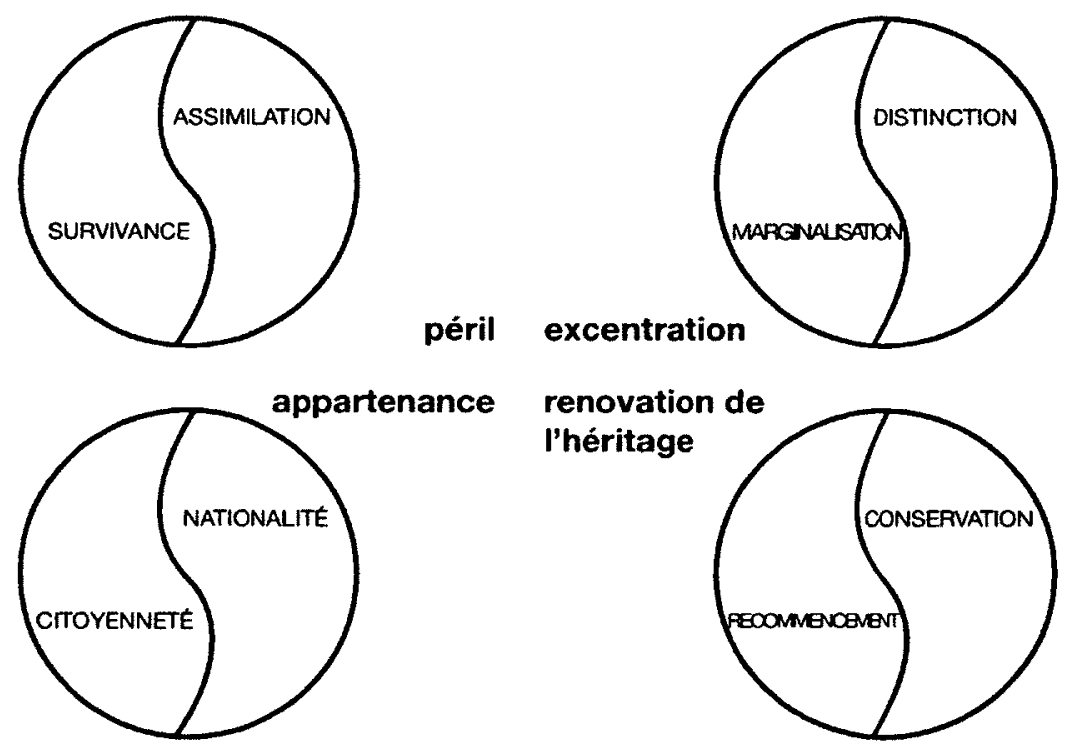

renovation de

l'héritage

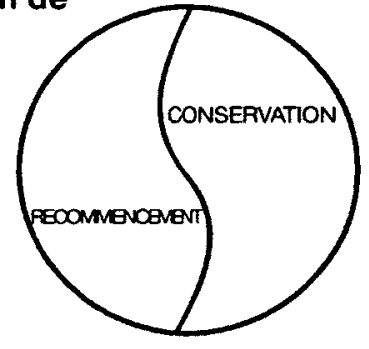

Each of the 'Poles' Describes the Tension Between Two Objectives

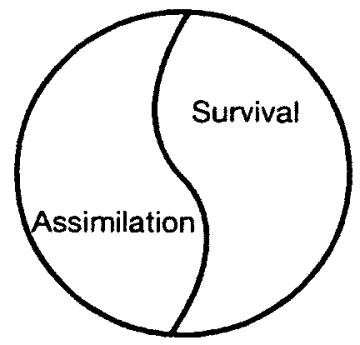

peril
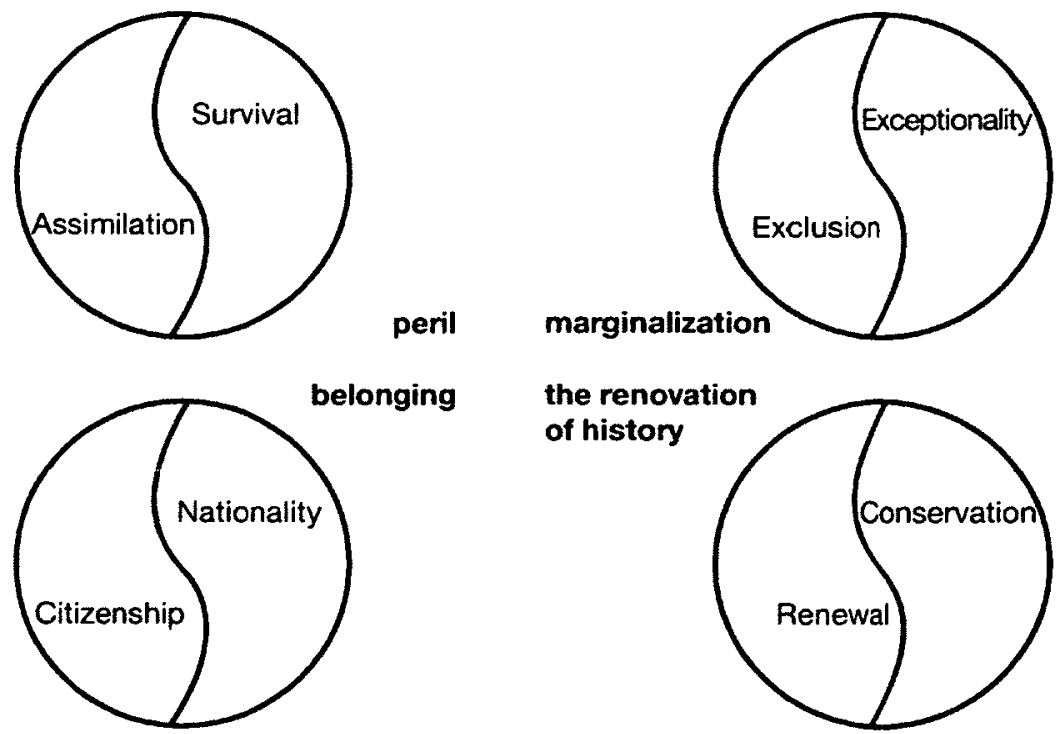

(Trépanier 2005:308) 
Appendix M

\section{LES TENSIONS DE LA REFONDATION}

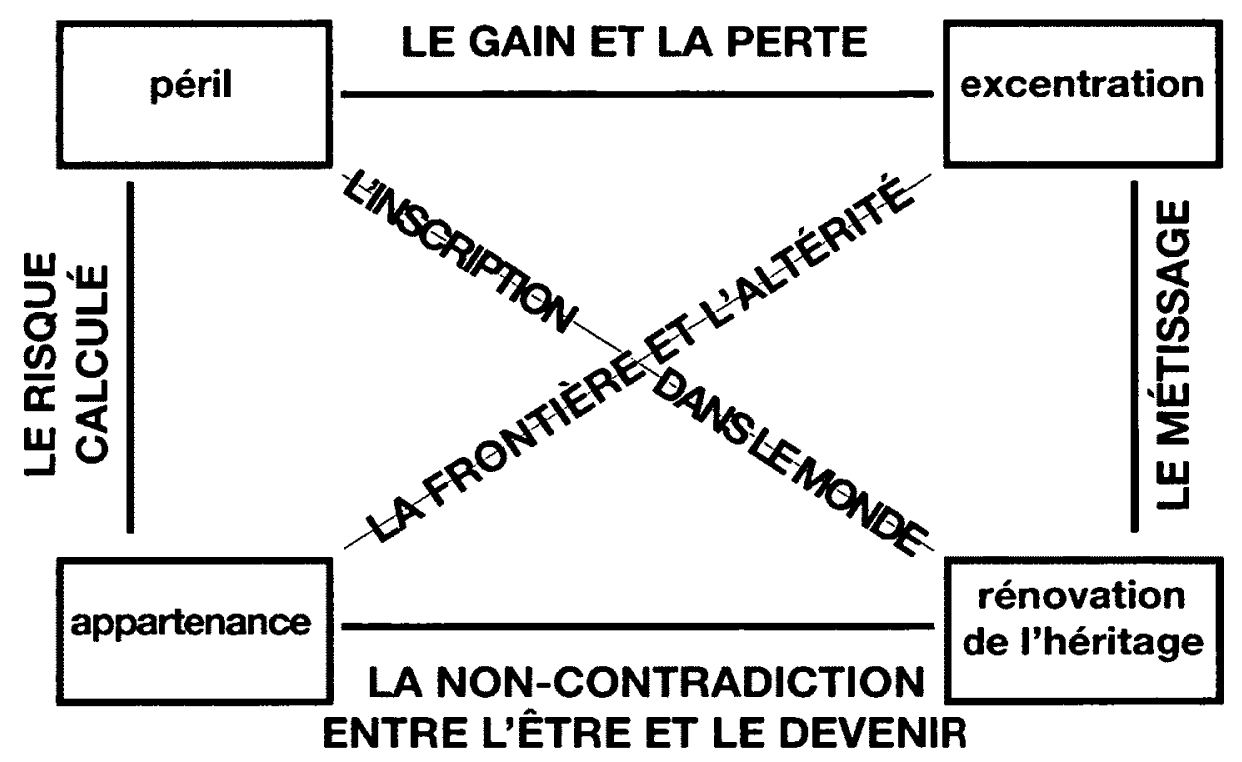

The Tensions Inherent in Refoundation

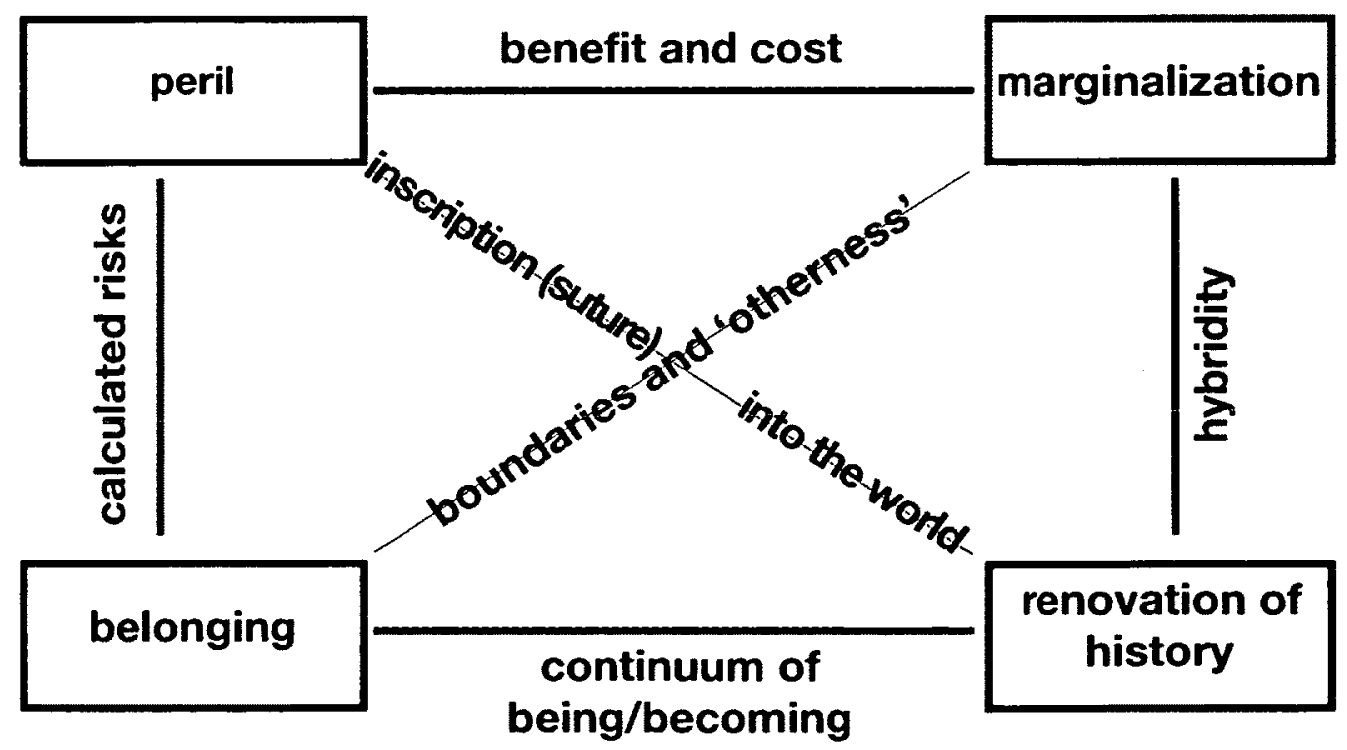

(Trépanier 2005:308) 


\section{References Cited:}

Adams, Jane

2002 Fighting for the Farm: Rural America Transformed. Philadelphia: University of Pennsylvania Press

Adger, Neil W.

2000 Social and Ecological Resilience: are they Related? Progress in Human Geography 24(3):347-364.

Agar, Michael

1996 The Professional Stranger. San Diego: Academic Press

Anderson, Benedict R.

1983 Imagined Communities: Reflections on the Origin and Spread of Nationalism. London: Verso.

Angus, Ian

1997 A Border Within: National Identity, Cultural Plurality, and Wilderness. Montréal; Buffalo: McGill-Queen's University Press.

Appadurai, Arjun

1996 Modernity at Large: Cultural Dimensions of Globalization. Minneapolis: University of Minneapolis Press.

Armstrong, J. Lloyd

1980 Clarendon and Shawville. Shawville QC: Dickson Enterprises.

Arnopoulos, Sheila MacLeod and Dominique Clift

1984 The English Fact in Quebec. Kingston, ON: McGill-Queen's University Press. 2nd ed.

Barth, Fredrik

1969 Introduction.Ethnic Groups and Boundaries: The Social Organization of Cultural Difference. (Results of a symposium held at the University of Bergen, 23rd to 26th February 1967.) Fredrik Barth (ed.). Pp 9-38. Bergen, Universitetsforlaget; London: Allen and Unwin.

Balibar, E \& Immanuel Wallerstein.

1996. Race, Nation, Class. New York: Verso. 
Bannerjee, Himani

1996 On The Dark Side of the Nation: Politics of Multi-Culturalism and the State of "Canada". Journal of Canadian Studies 31:3.

Bell, Michael M.

2007 The Two-ness of Rural Life and the Ends of Rural Scholarship. Journal of Rural Studies, 23:402-415.

Berger, Carl (ed.)

1987 Contemporary Approaches to Canadian History. Toronto: Copp Clark Pitman

Besser, Terry L.

2009 Changes in Small Town Social Capital and Civic Engagement. Journal of Rural Studies 25:185-193.

Blanchette, Roger

2009 L'Outaouais. Laval, Québec: Les Presses de l'Université Laval.

Bottomore, Tom (ed.)

1983 A Dictionary of Marxist Thought. Oxford, Oxfordshire : Blackwell Reference.

Bourdieu, Pierre

1990 The Logic of Practice. Richard Nice (trans.). Stanford, California: Stanford University Press.

Bourhis, Richard Y. (ed.)

1984 Conflict and Language Planning in Québec. Clevedon, Avon: Multilingual Matters

Bradbury, J. and I. St. Martin

1983 Winding Down in a Quebec Mining Town: A Case Study of Shefferville. Canadian Geographer 27(2):128-44.

Broadway, Michael J.

2000 Planning for Change in Small Towns or Trying to Avoid the Slaughterhouse Blues. Journal of Rural Studies 16:37-46.

Brodie, Janine

1990 The Political Economy of Canadian Regionalism. Toronto: Harcourt Brace Jovanovich, Canada.

Brubaker, Roger and Frederick Cooper

2000 Beyond "Identity". Theory and Society 29:1-47. 
Bryant, Christopher and Alun Joseph

2001 Canada's Rural Population: Trends in Space and Implications in Place. Canadian Geographer 45(1):132-138.

Bryden, John M. (ed.) with Lisa Leblanc and Craig Teal

1994 Towards Sustainable Rural Communities: The Guelph Seminar Series. Guelph [Ont.]: University School of Rural Planning and Development.

Burke, Joan

1989 Becoming an "Inside-Outsider". Journal of the Anthropological Society of Oxford 20: 219-27.

Butler, Judith

1988 Performative Acts and Gender Constitution: An Essay in Phenomenology and Feminist Theory. Theatre Journal 40(4):519-531.

Caldwell, Gary

1982 The English of Quebec: From Majority to Minority Status. Québec: Institut québécois de la recherche sur la culture.

1980 Le Québec anglophone hors de la région de Montréal dans les années soixante-dix: évolution sociodémographique Conseil de la langue française, Direction des études et recherches.

Careless, J.M.S.

1969 Limited Identities in Canada. Canadian Historical Review (March) 1-10.

Census of Canada

1931 Dominion Bureau of Statistics Canada. Seventh Census of Canada, 1931. Vol. II Population by Areas. Huntingdon.

CLD

2010 Rural Pact Renewal. Pontiac Rural Newsletter, Winter 2010 2:1, produced by B. Beaudry. Centre local de développement / Local Development Centre.

Clement, Wallace (ed.)

1997 Understanding Canada: Building on the New Canadian Political Economy. Montréal: McGill-Queen's University Press.

Clement, Wallace and Glen Williams (eds.)

1989 The New Canadian Political Economy. Kingston, Ont.: McGill-Queen's University Press. 
Clement, Wallace and Leah F. Vosko (eds.)

2003 Changing Canada: Political Economy as Transformation. Montréal: McGill-Queen's University Press.

Clement, Wallace and Vivian Shallah (eds.)

2007 Work in Tumultuous Times: Canadian Perspectives. Montréal: McGill-Queen's University Press.

Cloke, Paul (ed.)

1994 Writing the Rural: Five Cultural Geographies. London: P. Chapman Pub.

Cohen, Anthony P.

1985 The Symbolic Construction of Community. Chichester, England: Ellis Horwood Press.

Commerce Pontiac

N.d. SADC (société d'aide au développement de la collectivité). Pontiac Community Futures Development Corporation. http://www.commercepontiac.ca/home.html. Accessed Dec. 52011.

Cook, Ramsey

1967 Canadian Centennial Celebrations. International Journal 22(4):659-663.

Cruikshank, Julie

2005 Do Glaciers Listen?: Local Knowledge, Colonial Encounters, and Social Imagination. Vancouver : UBC Press

1998 The Social Life of Stories: Narrative and Knowledge in the Yukon Territory Vancouver: UBC Press.

Davies, Charlotte Aull

2008 Reflexive Ethnography: a Guide to Researching Ourselves and Others. London; New York: Routledge 2nd edition.

Elliott, Bruce $S$.

2004 Irish Migrants in the Canadas [electronic resource]: a New Approach. Kingston: McGill-Queen's University Press.

1988 Irish Migrants in the Canadas: A New Approach. Kingston and Montréal: McGillQueen's University Press.

1983 The North Tipperary Protestants in the Canadas: A Study of Migration. 1815-1880 Thesis (Ph. D.) - Carleton University, Ottawa. 
Everitr, J. and A. Gill

1993 The Social Geography of Small Towns. The Changing Social Geography of Canadian Cities. L.S. Bourne and D.F. Ley (eds.). Pp. 252-64. Montréal and Kingston: McGillQueen's University Press.

Foucault, Michel

1970 The Discourse on Language. The Archeology of Knowledge and the Discourse on Language. Michel Foucault. Pp. 215-237. New York: Pantheon.

Folke, Carl

2009 Turbulent Times (editorial). Global Environmental Change 19:1-3. www.elsevisier. com/locate/gloenvcha

2006 Resilience: The Emergence of a Perspective for Social-Ecological Systems Analyses. Global Environmental Change 16:253-267

Francis, Daniel

1997 National Dreams: Myth, Memory, and National History. Vancouver: Arsenal Pulp Press.

Friedman, Thomas L.

2007 The world is Flat: a Brief History of the Twenty-First Century. 1 st further updated and expanded hardcover ed. New York: Farrar, Straus and Giroux.

Frigon, Martin

2007 Contes, légendes et récits de l'Outaouais. Trois-Pistoles QC: Éditions Trois-Pistoles.

Frye, Northrop

2004 From Conclusion to a Literary History of Canada. Unhomely States: Theorising Canadian Postcolonialism. Cynthia Sugars (ed). Pp. 9-19. Peterborough ON:

Broadview Press.

Gaffield, Chad

1997 History of the Outaouais. Québec: Institut québécois de recherche sur la culture.

Gallopin, Gilberto C.

2006 Linkages Between Vulnerability, Resilience, and Adaptive Capacity. Global Environmental Change 16:293-303. www.elsevier.com/locate/gloenvcha

Gagnon, Alain

1993 Quebec: State and Society. 2nd edition. Toronto: Methuen. 
Geertz, Clifford

1973 Thick Description: Toward an Interpretive Theory of Culture. The Interpretation of Cultures. C. Geertz. Pp. 1-30. New York: Basic Books.

Gourlay, John L.

1896 History of the Ottawa Valley: a Collection of Facts, Events and Reminiscences for over Half a Century. [S.1. : s.n., ca. 1896]

Graham, Gordon G.

2000 Suffering from a Want of Communication: A History of Transportation in Pontiac County. Pontiac Wagon Train 2000: Pontiac Print Shop.

1994 "Our Surest Hopes of Prosperity": Economic Development in Pontiac County's Railway Era 1880-1920. MA Thesis. History. Carleton University.

Green, Sarah F.

2005 Notes from the Balkans: Locating Marginatlity and Ambiguity on the GreekAlbanian Border. Princeton and Oxford: Princeton University Press.

Gunderson, Lance $\mathrm{H}$.

2000 Ecological Resilience - In Theory and Application. Annual Review of Ecology and Systematics. 31:425-39.

Gunderson, Lance and C.S. Holling (eds.)

2002 Panarchy: Understanding Transformations in Human and Natural Systems. Washington; Covelo; London: Island Press.

Gunderson, Lance H., C.S. Holling and Steven S. Light (eds.)

1995 Barriers and Bridges to the Renewal of Ecosystems and Institutions. New York: Columbia University Press.

Hall, Stuart

1996 Introduction: Who needs 'identity'? Questions of cultural identity. Stuart Hall \& Paul Du Gay (Eds.). Pp 1-17. London/ Thousand Oaks: Sage Publications.

1992 Modernity and its Futures. Stuart Hall, David Held and Tony McGrew (eds.) Cambridge UK : Polity Press in association with the Open University.

Halpern, Claire and Clare J.A. Mitchell

2011 Can a Preservationist Ideology Halt the Process of Creative Destruction? Evidence from Salt Spring Island, British Columbia. The Canadian Geographer / Le Géographe canadien 55(2): 208-225 
Halseth, Greg

1998 Cottage Country in Transition: A Social Geography of Change and Contention in the Rural-Recreational Countryside. Montréal \& Kingston: McGill-Queen's University Press.

Handler, Richard

1994 Is Identity a Useful Cross-Cultural Concept? Commemorations: The Politics of National Identity. J. Gillis (ed.). Pp. 27-40. Princeton: Princeton University Press.

1988 Nationalism and the Politics of Culture in Quebec. Madison, Wisconsin: The University of Wisconsin Press.

Handler, Richard and Daniel Segal

1990 Jane Austen and the Fiction of Culture: An Essay on the Narration of Social Realities. Tucson: The University of Arizona Press.

Hardt, Michael and Antonio Negri

2000 Empire. Cambridge, Massachusetts; London, England: Harvard University Press.

Hirsch, R. Forbes

1985 The Upper Ottawa Valley Timber Trade: a Sketch. The Historical Society of Ottawa. Bytown pamphlet series no. 14.

Hobsbawm, Eric and Terence Ranger (eds.)

1983 The Invention of Tradition. Cambridge [Cambridgeshire]; New York: Cambridge University Press.

Holling, C.S.

1973 Resilience and Stability of Ecological Systems. Annual Review of Ecology and Systematics 4:1-24.

Homer-Dixon, Thomas

2001 The Ingenuity Gap. Toronto. Vintage Canada.

Ignatieff, Michael

1993 Blood and Belonging. Toronto: Viking Press.

Innis, Harold

1995 Staples, Markets and Cultural Change: Selected Essays/ Harold A. Innis. Daniel Drache (ed.). Montréal: McGill-Queen's University Press.

1962 The Fur Trade in Canada: an Introduction to Canadian Economic History. (with a foreword by Robin W. Winks). Toronto: University Press. 
Jedwab, Jack (ed.)

2010 The Deep Diversity of English-Speaking Quebecers. Canadian Diversity/Diversité Canadienne Vol.8(2). Association for Canadian Studies.

2004 Going Forward: the Evolution of Québec's English-speaking Community. Ottawa: Office of the Commissioner of Official Languages.

King, Thomas

2003 The Truth about Stories: a Native Narrative. Toronto: House of Anansi Press.

Klein, Julie

1990 "Introduction and Chapter 1" Interdisciplinarity: History, Theory, and Practice. Pp. 11-16, 19-39. Detroit: Wayne State University Press.

Kouritzin, Sandra G., Nathalie A.C. Piquemal, Renee Norman (eds.)

2009 Qualitative Research : Challenging the Orthodoxies in Standard Academic Discourse(s) New York: Routledge.

Labaree, Robert V.

2002 The Risk of 'Going Observationalist': Negotiating the Hidden Dilemmas of Being an Insider Participant Observer. Qualitative Research 2(1):97-122.

Laberge, Edward P.

1989 Philemon Wright: A Yankee Who Helped Build Canada. The Historic Society of Ottawa. Bytown pamphlet series No. 30.

Laker, Jason

2011 Canadian Perspectives on Men and Masculinities: An Interdisciplinary Reader. Oxford University Press: http://www.oup.com/us/catalog/general/subject/Sociology/ Regional/?view=usa\&sf =toc\&ci $=9780195439243$

Latour, Bruno

2010 An Attempt at a "Compositionist Manifesto". New Literary History 41:471-490.

2007 A Plea for Earthly Sciences - Lecture to the annual meeting of the British Sociological Association. East London: April 2007. http://www.bruno-latour.fr/articles/ article/102-BSA-GB.pdf

Leckie, Gloria J.

1989 Continuity and Change in the Farm Community: Brooke Township, Ontario, 196586. The Canadian Geographer/Le Géographe canadien 33(1):32-46.

Lefebvre, Henri

1991 The Production of Space. Donald Nicholson-Smith (trans.), London: Blackwell. 
Létourneau, Jocelyn

2004 A History for the Future: Rewriting Memory and Identity in Quebec. Phyllis Aronoff and Howard Scott (trans.) Montreal: McGill-Queen's University Press.

Levine, Marc

1990 Bill 101 and the Politics of Language, 1977-1989. The Reconquest of Montreal: Language Policy and Social Change in a Bilingual City. Pp. 111-147. Philadelphia: Temple University Press.

Liepins, Ruth

2000 New Energies for an Old Idea: Reworking Approaches to 'Community' in Contemporary Rural Studies. Journal of Rural Studies 16:23-35.

Little, Jo

1999 Otherness, Representation and the Cultural Construction of Rurality. Progress in Human Geography 23(3):437-442.

Mackenzie, F.

1992 "The Worse it Got the More we Laughed": a Discourse of Resistance Among Farmers of Eastern Ontario. Environment and Planning D: Society and Space 10:691-713.

MAPAQ

2011 L'Outaouais : plus proche de la nature. Ministère de l'Agriculture, Pêcheries et Alimentation Québec. Régions du Québec: 07 l'Outaouais. http://www.mapaq.gouv. qc.ca/fr/Regions/outaouais/Pages/Profildelaregion.aspx, Accessed Dec. 52011.

2008 Portrait Sommaire L'Industrie agricole et agroalimentaire de la MRC Pontiac. Ministère de l'Agriculture, Pêcheries et Alimentation Québec. La direction régionale de l'Outaouais-Laurentides, secteur Outaouais. http://www.mapaq.gouv. qc.ca/SiteCollectionDocuments/Regions/Outaouais/Portrait_Pontiac_francais.pdf, Accessed Dec.5 2011.

Markey, Sean, Greg Halseth and Don Mansen (eds.)

2012 Investing in Place: Economic Revival in Northern B.C. Vancouver, Toronto: University of British Columbia Press.

2008 Challenging the Inevitability of Rural Decline: Advancing the Policy of Place in Northern British Columbia. Journal of Rural Studies 24(4):409-421.

Marshall, Joan

1995 A Solitary Pillar: Montreal's Anglican Church and the Quiet Revolution. Montréal; Buffalo: McGill-Queen's University Press. 
Mead, Margaret

1970 Culture and Commitment. New York. Natural History Press / Doubleday \& Company, Inc.

Mechling, Jay

1991 Homo Narrans across the Disciplines. Western Folklore 50 (1):41-51. Stable URL: http://www.jstor.org/stable/1499396

Meinhof, Ulrike and Dariusz Galasinski

2005 The Language of Belonging. Basingstoke, UK: Palgrave Macmillan.

Midmore, Peter, Mark D. Partridge, M. Rose Olfert and Kamar Ali

2010 The Evaluation of Rural Development Policy: Macro and Micro Perspectives. EuroChoices. The Agricultural Economics Society and the European Association of Agricultural Economists. 9(1):24-29.

Mitchell, Clare J.A. and Sarah B. de Waal

2009 Revisiting the Model of Creative Destruction: St. Jacobs, Ontario, a Decade Later. Journal of Rural Studies 25(1):156-167.

Mitchell, Katharyne

2003 Educating the National Citizen in Neoliberal Times: From the Multicultural Self to the Strategic Cosmopolitan. Pp 387-403. Transactions of the Institute of British Geographers. 28(4): 387-403.

Moore, Bruce

2007 Original Sin and Insider Research. Action Research 5(1):27-39.

Moran, Joe

2002 Interdisciplinarity. London and New York: Routledge

Mookerjea Sourayan, Imre Szeman, and Gail Faurschou (ed.)

2009 Canadian Cultural Studies. A Reader. Durham, Duke University Press.

Neelin, Lyndal

2007 Exploring the 'Habitus' of Empire as Lived by 20th Century English-Speaking White South Africa. Thesis (M.A.) Carleton University.

Newton, Michael

1991 Some Notes on Bytown and the Fur Trade. The Historical Society of Ottawa. Bytown pamphlet series No. 35. 
Niles, John D.

1999 Homo Narrans: The Poetics and Anthropology of Oral Literature. Philadelphia: University of Pennsylvania Press.

Oakes, Leigh and Jane Warren (eds.)

2007 Language, Citizenship and Identity in Québec. Basingstoke [England]; New York: Palgrave Macmillan.

Osborne, Brian

2001 Landscapes, Memory, Monuments, and Commemoration: Putting Identity in its Place. Canadian Ethnic Studies 33(3):39-77.

Ó Tuathail, Gearóid. (Gerald O’Toole)

1996 "Preface" in Critical Geopolitics: the Politics of Writing Global Space. Minneapolis: University of Minnesota Press.

Padolsky, Enoch and Ian Pringle (eds.)

1981 A Historical Source Book for the Ottawa Valley. Ottawa: Linguistic Survey of the Ottawa Valley, Carleton University.

Parson, Helen

1977 An Investigation of the Changing Rural Economy of Gatineau County, Quebec. Canadian Geographer 21 (1):22-31.

Patterson, Pat

1989 Harvests Past: Domestic and Agricultural Hand Tools and Rural Life in the Ottawa Valley, 1860-1875. Erin, Ont.: Boston Mills Press.

Patton, Michael Quinn

2002 Two Decades of Developments in Qualitative Inquiry: A Personal, Experiential Perspective. Qualitative Social Work 1(3):261-283

1990 Qualitative Evaluation and Research Methods (2nd ed.). Newbury Park, CA: Sage Publications, Inc.

Pawlick, Thomas

2009 The War in the Country: How the Fight to Save Rural Life will Shape our Future. Vancouver: Greystone Books.

Polanyi, Karl

2001 [1944] The Great Transformation: the Political and Economic Origins of Our Time. foreword by Joseph E. Stiglitz ; introduction by Fred Block. Boston, MA.: Beacon Press. 2nd Beacon Paperback ed. 
Pontiac Portal

2010 MRC Pontiac MRC. http://www.pontiacportal.qc.ca

Portelli, Alessandro

1991 The Death of Luigi Trastulli, and Other Stories: Form and Meaning in Oral History. Albany, N.Y.: State University of New York Press.

Pritchard, Lowell Jr., J. Colding, F. Berkes, U. Svedin and C. Folke.

1998 The Problem of Fit Between Ecosystems and Institutions. IDHP Working Paper 2. Bonn: International Human Dimensions Program.

Québec Community Groups Network

2010 Community Development Plan for the English-speaking Communities of Quebec 2005-2010. Official Languages Support Program of the Department of Canadian Heritage. http://www.ocol-clo.gc.ca/docs/f/Community_Development_Plan.pdf

Redman, Charles L., and Ann P. Kinzig

2003 Resilience of Past Landscapes: Resilience Theory, Society, and the Longue Duree Conservation Ecology 7(1):14. http://www.consecol.org/vol7/iss1/art14

Reimer, Bill

2006 The Rural Context of Community Development in Canada. Journal of Rural and Community Development 1:155-175.

Rudin, Ronald

1985 The Forgotten Quebecers: a History of English-speaking Quebec, 1759-1980. Québec: Institut québécois de recherché sur la culture: Distribution, Diffusion Prologue.

Salter, Liora and Alison Hearn (eds.)

1996 Introduction, Chapters 1 and 2. Outside the Lines: Issues in Interdisciplinary Research. Pp. 3-43. Montreal: McGill-Queen's University Press.

Scowen, Reed

1991 A Different Vision: the English in Quebec in the 1990s. Don Mills, ON: Maxwell Macmillan Canada.

Singer, Merrill

1994 Community-Centred Praxis: Toward an Alternative Non-Dominative Applied Anthropology. Human Organization 53 (4) Pp. 336-344.

Smith, Dorothy

1989 Feminist Reflections on Political Economy. Studies in Political Economy 30. 
Statistics Canada

2012 Arnprior, Ontario (Code 0021) and Ontario (Code 35) (table). Census Profile. 2011 Census. Statistics Canada Catalogue no. 98-316-XWE. Ottawa. Released February 8. http://www12.statcan.ca/census-recensement/2011/dp-pd/prof/index.cfm?Lang=E Accessed April 18, 2012.

2012 Carleton Place, Ontario (Code 0140) and Ontario (Code 35) (table). Census Profile. 2011 Census. Statistics Canada Catalogue no. 98-316-XWE. Ottawa. Released February 8. http://www12.statcan.ca/census-recensement/2011/dp-pd/prof/index. cfm?Lang=E Accessed April 18, 2012.

2012 Embrun, Ontario (Code 0260) and Manitoba (Code 46) (table). Census Profile. 2011 Census. Statistics Canada Catalogue no. 98-316-XWE. Ottawa. Released February 8. http://www12.statcan.ca/census-recensement/2011/dp-pd/prof/index. cfm?Lang=E Accessed April 18, 2012.

2012 Pontiac, Quebec (Code 2484) and Quebec (Code 24) (table). Census Profile. 2011 Census. Statistics Canada Catalogue no. 98-316-XWE. Ottawa. Released February 8. http://www12.statcan.ca/census-recensement/2011/dp-pd/prof/index.cfm?Lang=E Accessed April 18, 2012.

2012 Shawville, Quebec (Code 0752) and Quebec (Code 24) (table). Census Profile. 2011 Census. Statistics Canada Catalogue no. 98-316-XWE. Ottawa. Released February 8. http://www12.statcan.ca/census-recensement/2011/dp-pd/prof/index.cfm?Lang=E Accessed April 18, 2012.

2007 Shawville, Quebec (table). 2006 Community Profiles. 2006 Census. Statistics Canada Catalogue no. 92-591-XWE. Ottawa. Released March 13. http://www12. statcan.ca/census-recensement/2006/dp-pd/prof/92-591/index.cfm?Lang=E Accessed November 29, 2009.

2007 Huntingdon, Quebec (table). 2006 Community Profiles. 2006 Census. Statistics Canada Catalogue no. 92-591-XWE. Ottawa. Released March 13. http://wwwl2. statcan.ca/census-recensement/2006/dp-pd/prof/92-591/index.cfm?Lang=E Accessed June 25, 2011.

Stedman, Richard C., John R. Parkins and Thomas M. Beckley

2004 Resource Dependence and Community Well-Being in Rural Canada. Rural Sociology 69(2):213-234.

Stevenson, Garth

2006 Parallel Paths: the Development of Nationalism in Ireland and Quebec. Montréal: McGill-Queen's University Press. 
Sullivan, Shannon

2006 Revealing Whiteness: the Unconscious Habits of Racial Privilege. Bloomington: Indiana University Press.

Taylor, Jodie

2011 The Intimate Insider: Negotiating the Ethics of Friendship When Doing Insider Research. Qualitative Research 11(1):3-22.

Thiele, Christina A.L.

1986 Irish Features in the English of Upper Ottawa Valley Germans. MA Thesis. School of Canadian Studies. Carleton University.

Trépanier, Anne

2009 "Introduction" in la rénovation de l'héritage démocratique : entre fondation et refondation. Ottawa: University of Ottawa Press.

2005 La permanence de la refondation dans l'imaginaire et l'identitaire politiques des Canadiens: de la Nouvelle-France au Canada moderne, 1663-1867. PhD dissertation. History. Laval University.

Trew, Johanne Devlin

2009 Place, Culture and Community: the Irish Heritage of the Ottawa Valley. Newcastle Cambridge Scholars.

Troughton, Michael J.

1995 Presidential address: Rural Canada and Canadian Rural Geography - An Appraisal. Canadian Geographer 39(4):291-305. http://proquest.umi.com/pqdweb?did =92643 $84 \& \mathrm{Fmt}=3 \&$ clientld $=13709 \& \mathrm{RQT}=309 \& \mathrm{VName}=\mathrm{PQD}$

Walker, Brian and David Salt

2006 Resilience Thinking: Sustaining Ecosystems and People in a Changing World. Washington: Island Press.

Warren, Jean-Philipe

2003 The History of Québec in the Perspective of the French Language. Linguistic Conflict and Language Laws: Understanding the Québec Question. Pierre Larrivée (ed.) Pp. 57-86 Barringstoke / New York: Palgrave MacMillan.

Wilson, Geoff

2010 Multifunctional 'Quality' and Rural Community Resilience. Transactions of the Institute of British Geographers NS 35:364-381. 
The Equity

The Pontiac Journal du Pontiac

The Ottawa Citizen

The Quebec Chronicle-Telegraph 